\title{
GEOLOGY OF THE HANNA FORMATION, HANNA UNDERGROUND COAL GASIFICATION SITE, HANNA, WYOMING
}

By

R.L. Oliver

A.D. Youngberg

January 1984

Work Performed Under Cooperative Agreement No.: DE-AC07-76ET10723

For

U.S. Department of Energy

Office of Fossil Energy

Morgantown Energy Technology Center

Laramie Project Office

Laramie, Wyoming

By

Associated Western Universities, Inc.

Salt Lake City, Utah

Technical Information Center

Office of Scientific and Technical Information

United States Department of Energy 


\title{
DISCLAIMER
}

\begin{abstract}
This report was prepared as an account of work sponsored by an agency of the United States Government. Neither the United States Government nor any agency thereof, nor any of their employees, makes any warranty, express or implied, or assumes any legal liability or responsibility for the accuracy, completeness, or usefulness of any information, apparatus, product, or process disclosed, or represents that its use would not infringe privately owned rights. Reference herein to any specific commercial product, process, or service by trade name, trademark, manufacturer, or otherwise does not necessarily constitute or imply its endorsement, recommendation, or favoring by the United States Government or any agency thereof. The views and opinions of authors expressed herein do not necessarily state or reflect those of the United States Government or any agency thereof.
\end{abstract}

This report has been reproduced directly from the best available copy.

Available from the National Technical Information Service, U. S. Department of Commerce, Springfield, Virginia 22161.

Price: Printed Copy A08

Microfiche A01

Codes are used for pricing all publications. The code is determined by the number of pages in the publication. Information pertaining to the pricing codes can be found in the current issues of the following publications, which are generally available in most libraries: Energy Research Abstracts (ERA); Government Reports Announcements and Index (GRA and I); Scientific and Technical Abstract Reports (STAR); and publication NTIS-PR-360 available from NTIS at the above address. 


\section{DISCLAIMER}

This report was prepared as an account of work sponsored by an agency of the United States Government. Neither the United States Government nor any agency Thereof, nor any of their employees, makes any warranty, express or implied, or assumes any legal liability or responsibility for the accuracy, completeness, or usefulness of any information, apparatus, product, or process disclosed, or represents that its use would not infringe privately owned rights. Reference herein to any specific commercial product, process, or service by trade name, trademark, manufacturer, or otherwise does not necessarily constitute or imply its endorsement, recommendation, or favoring by the United States Government or any agency thereof. The views and opinions of authors expressed herein do not necessarily state or reflect those of the United States Government or any agency thereof. 


\section{DISCLAIMER}

Portions of this document may be illegible in electronic image products. Images are produced from the best available original document. 


\title{
GEOLOGY OF THE HANNA FORMATION, HANNA UNDERGROUND COAL GASIFICATION SITE, HANNA, WYOMING
}

\author{
By \\ R.L. Oliver \\ A.D. Youngberg \\ January 1984 \\ Work Performed Under Cooperative Agreement No.: DE-AC07-76ET10723 \\ For \\ U.S. Department of Energy \\ Office of Fossil Energy \\ Morgantown Energy Technology Center \\ Laramie Project Office \\ Laramie, Wyoming 82071 \\ By \\ Associated Western Universities, Inc. \\ 142 E. 200 South \\ Salt Lake City, Utah 84111
}




\section{CONTENTS}

Page

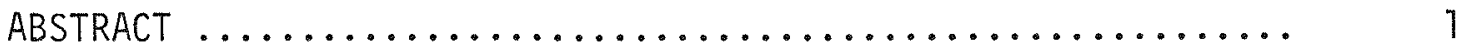

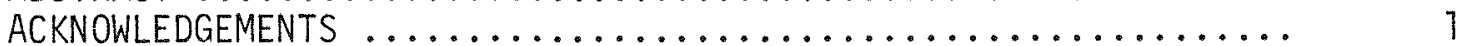

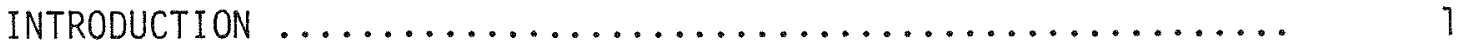

Hanna UCG Site ................................ I

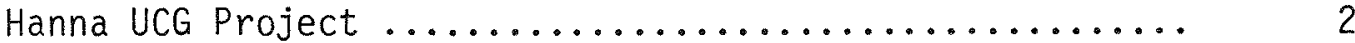

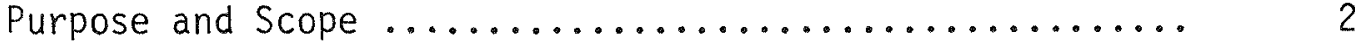

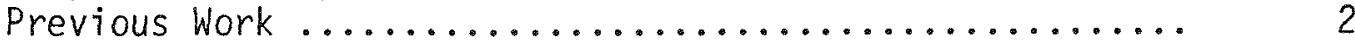

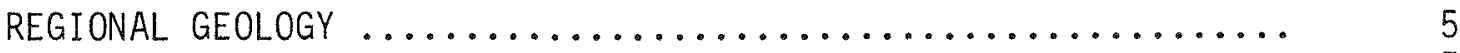

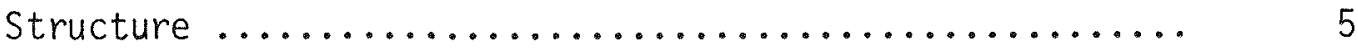

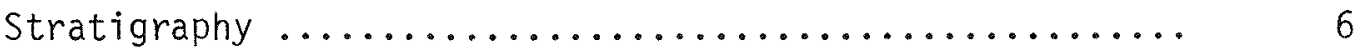

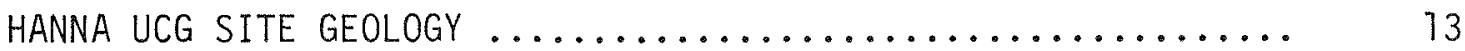

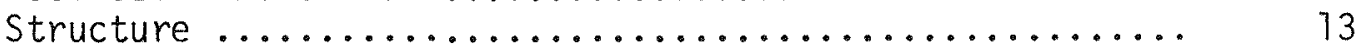

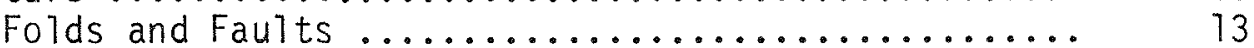

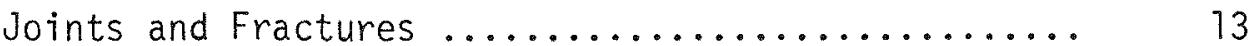

Hanna No. 1 Coal Bed Core Study ................ 18

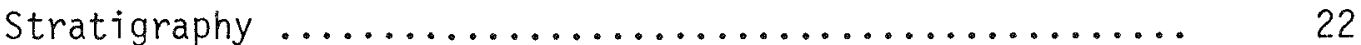

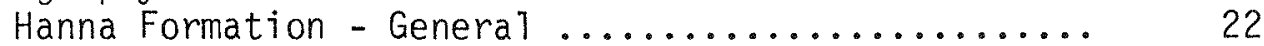

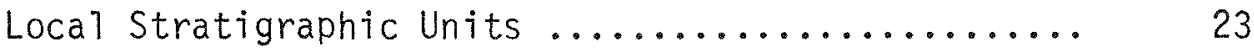

Hanna No. 1 Coal Seam ................... 23

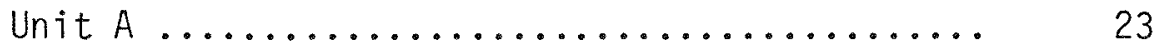

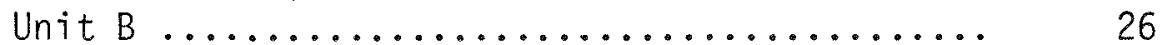

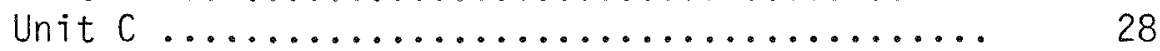

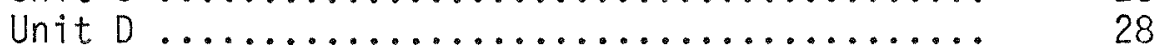

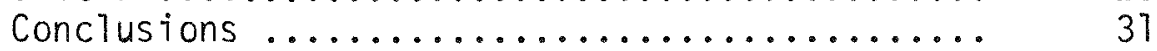

Stratigraphic Unit Geometry ............... 38

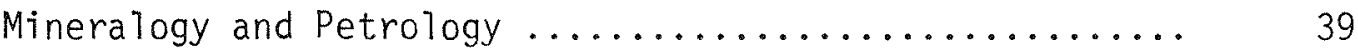

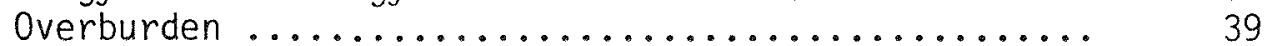

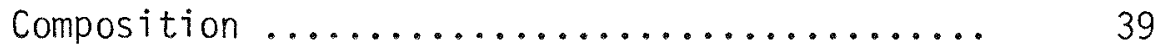

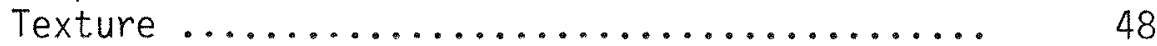

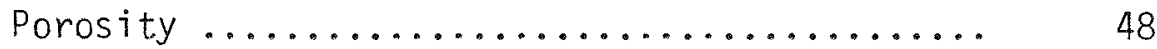

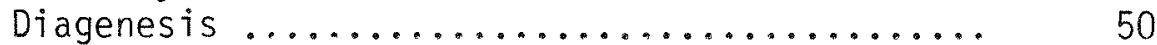

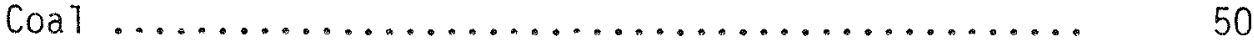

Proximate and Ultimate Analysis ........... 50

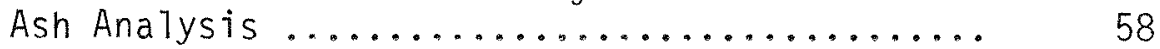

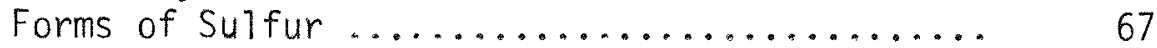

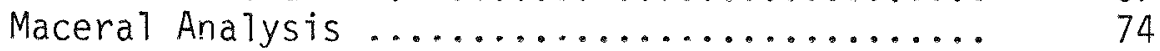

Mean-Maximum Vitrinite Reflectance ........... 79

Rank .............................. 79 


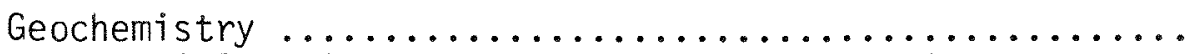
86

Semi-Quantitative Spectrographic Analys is ........

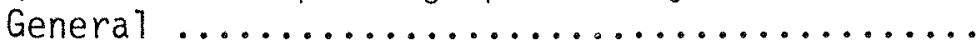
Correlations

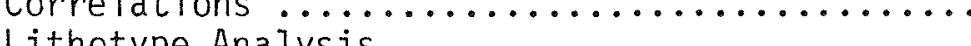

86

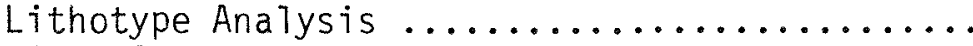

Analytical Analysis

102

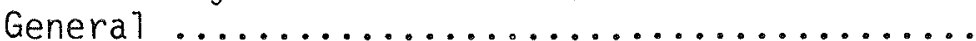

109

Correlations

109

109

SUMMARY

114

REFERENCES $\ldots \ldots \ldots \ldots \ldots \ldots \ldots \ldots \ldots \ldots \ldots \ldots \ldots \ldots \ldots \ldots \ldots \ldots \ldots \ldots$

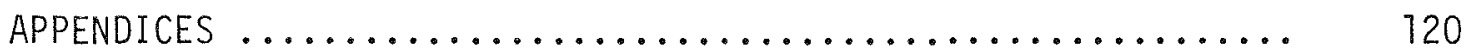

Appendix A: Depth Intervals from Geophysical Logs ...... 120

Appendix B: Element and Ash Concentration Profiles ...... 124

Appendix C: Structural Contour Map, Hanna No. 1 Coal .... 144 


\section{ILLUSTRATIONS}

Figure

1. Generalized location map of the Hanna Basin and surrounding mountains and uplifts ................ 3

2. Location map of Hanna UCG site .................... 4

3. Structure contour map of the Hanna No. 1 coal bed ....... 7

4. Geologic map of the Hanna Coal Field ............... 8

5. Upper Cretaceous and Lower Tertiary stratigraphy of the

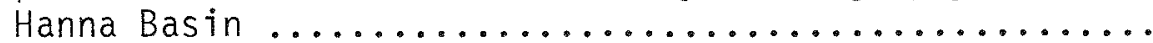

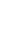

6. Coal nomenclature in the Hanna Mining District of the Hanna Coat Field ............................... 10

7. Isopach map of the Hanna No. 1 coat bed ............. 11

8. Overburden isopach map of the Hanna No. 1 coal bed ..... 12

9. Structural contour map on top of the Hanna No. 1

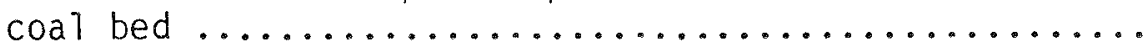

10. Generalized northeast-southwest structural cross section of the Hanna UCG area ................... 15

11. Joint sets in the coals of the Hanna Formation ......... 16

12. Azimuth versus frequency plot for a 71 joints measured in oriented core from Hanna No. 1 coal seam .......... 19

13. Photograph of oriented core from $\mathrm{CH}-2$, Hanna UCG site ... 20

14. Diagram relating the dominant joint directions to the dominant directions of fautting ................... 21

15. Subdivision of the overburden of the Hanna No. 1 coal bed at the Hanna UCG site ........................ 24

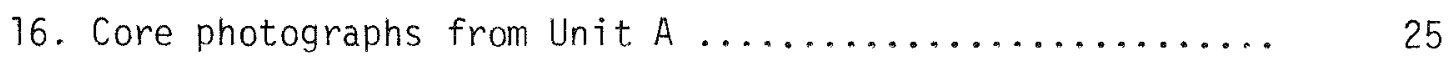

17. Core photographs from Unit B ................... 27

18. Core photographs from Unit C ................... 29

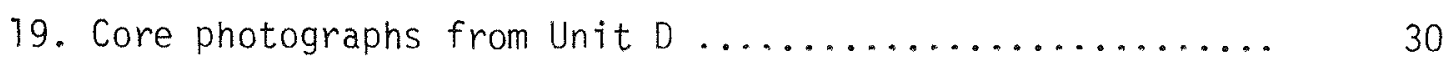


20. Schematic reconstruction of inferred depositional settings of the overburden units, Hanna UCG site

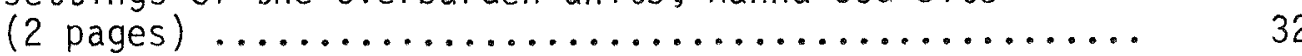

21. Northeast to southwest stratigraphic cross section A-A' . 34

22. Northwest to southeast stratigraphic cross section $B-B^{\prime}$. 35

23. Northwest to southeast stratigraphic cross section $C-C^{\prime}$. 36

24. Northwest to southeast stratigraphic cross-section D-D' . 37

25. Overburden rock types in Unit $A$ at the Hanna UCG study

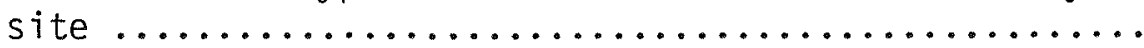

26. Overburden bulk mineralogy in Unit $A$ at the Hanna UCG

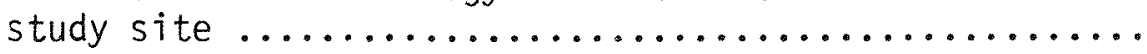

27. Bulk mineralogy of the calcareous sandstone rock

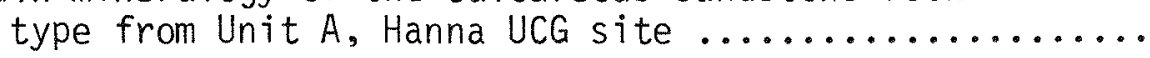

28. Bulk mineralogy of the calcareous siltstone rock

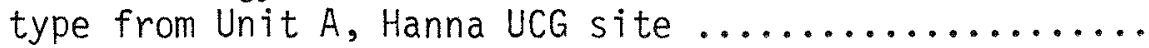

29. Bulk mineralogy of the calcareous shale rock

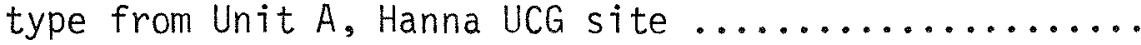

30. Bulk mineralogy of the ironstone rock type from Unit $A$,

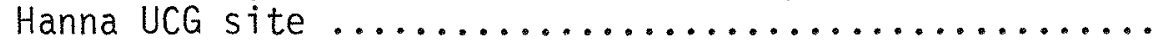

31. Bulk mineralogy of the carbonaceous shale rock

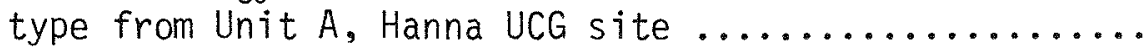

32. As received proximate analys is for $\mathrm{CH}-133$, Hanna

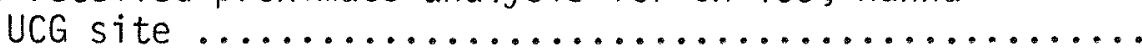

33. Moisture free proximate analys is for $\mathrm{CH}-133$, Hanna

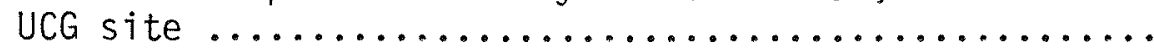

34. Moisture and ash free ultimate analys is for $\mathrm{CH}-133$,

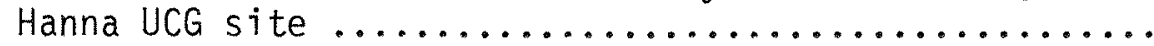

35. Distribution of total sulfur in Hanna No. 1 coal for Corehole II-4, Hanna UCG site ...................

36. Distribution of total sulfur in Hanna No. 1 coal for

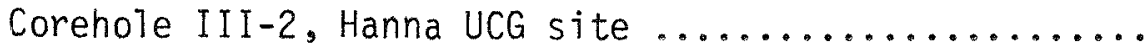

37. Distribution of total sulfur in Hanna No. 1 coal for Corehole IV-2, Hanna UCG site 
38. Minerals in the Hanna No. 1 coal bed, Hanna UCG site ....

39. Distribution of calcite/aragonite minerals in the Hanna No. I coal bed for Corehole I-16, Hanna

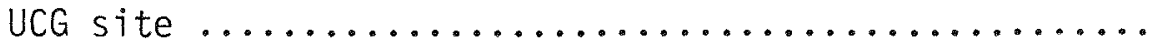

40. Distribution and mineral form of iron in the Hanna No.

1 coal in Corehole I-16, Hanna UCG site ............. 61

41. Ash analysis of oxides for CH-133, Hanna UCG site ...... 62

42. Element concentration of coal versus carbonaceous shale in Corehole 2HP-170, Hanna UCG site (2 pages) ..........

43. Distribution of organic sulfur in the Hanna No. 1 coal for Corehole I-16, Hanna UCG site ...................

44. Distribution of pyritic sulfur in the Hanna No. 1 coal

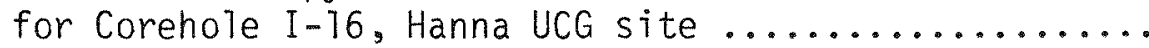

45. Distribution of sulfate sulfur in the Hanna No. 1 coal for Corehole I-16, Hanna UCG site ................ 70

46. Distribution of total sulfur in the Hanna No. 1 coal for Corehole I-16, Hanna UCG site ................ 71

47. Pyrite forms in the Hanna No. 1 coal, Hanna UCG site.... 73

48. Photomicrographs of coal macerals ............... 76

49. Maceral analysis profile of $\mathrm{CH}-133$, Hanna UCG site ..... 77

50. Distribution of vitrinoid types of $\mathrm{CH}-133$, Hanna

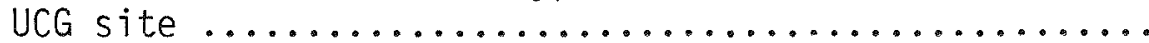

51. Classification of coal from the Hanna No. 1 coal seam

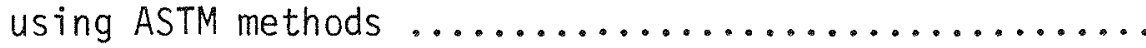

52. Percent ash content in carbonaceous shale, subbituminous coal, and bituminous coal from the Hanna No. I

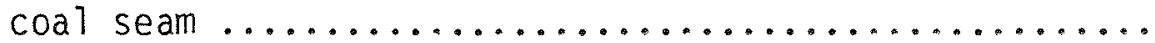

53. Distribution of ash percentage in the Hanna No. 1 coal seam for three coreholes from the Hanna UCG site ......

54. Classification of coal from the Hanna No. 1 coal seam using mean-maximum vitrinite reflectance .............

55. Diagrammatic representation of element concentration trends in the Hanna No. 1 coal seam, Hanna

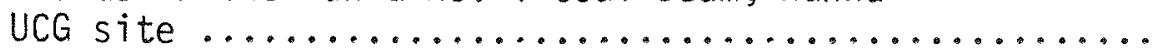


56. Diagrammatic representation of element concentration

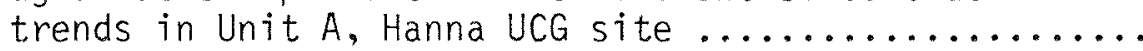

57. Diagrammatic representation of element concentration trends in Unit $C$, Hanna UCG site .................

58. Graphic representation of local stratigraphic unit correlations within each hole, Hanna UCG site .........

101

59. Numeric representation of relative element concentrations

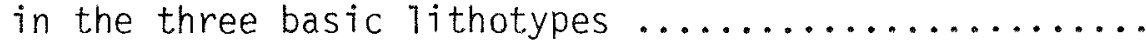

102

60. Diagrammatic representation of analytical analys is

trends in the Hanna No. 1 coal seam, Hanna UCG site ...

\section{PLATES}

Plate

Page

I. Isopach map of the Hanna No. 1 coal bed, Hanna UCG Back

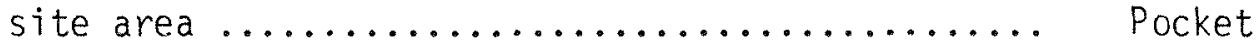

II. Isopach map of local stratigraphic Unit A, Hanna UCG Back site area .......................... Pocket

III. Isopach map of local stratigraphic Unit B, Hanna UCG Back

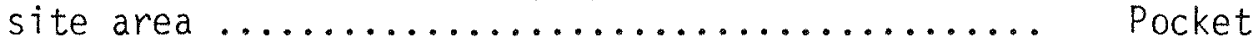

IV. Isopach map of local stratigraphic Unit C, Hanna UCG Back

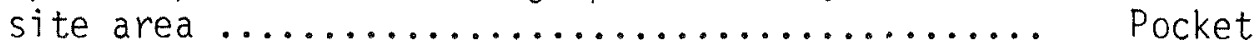

V. Isopach map of local stratigraphic Unit D, Hanna UCG Back site area ............................ Pocket

VI. Isopach map of total overburden, Hanna UCG site... Back

Pocket

VII. Mean ash percent isogram map, Hanna UCG site...... Back

Pocket 


\section{TABLES}

Table

Page

1. Classification of fractures in coal ............... 14

2. Average composition of fifty-nine sandstone samples from the Hanna Formation, Hanna, Wyoming .............

3. Average textural and porosity values for fifty-nine sandstone samples from the Hanna Formation,

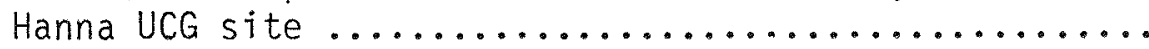

4. Summary of proximate, ultimate, and calorific value analyses of coal from the Hanna UCG site ..............

5. Ash percentage values for six coreholes at the

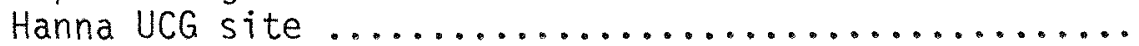

6. Oxides in ash of Hanna bituminous coats .............. 63

7. Element anatysis of Hanna bituminous coals ............ 64

8. Sulfur forms in Hanna No. 1 coal bed ................ 67

9. Analysis of pyrite forms in Hanna No. 1 coals ......... 72

10. Maceral classification describing the macerals that were studied at the Hanna UCG site ................. 75

11. Maceral analysis from the Hanna UCG site ............. 79

12. Classification of coals by rank ................. 80

13. Classification of coals by rank using maximum reflectance percent .......................... 81

14. Average semi-quantitative spectrographic analysis

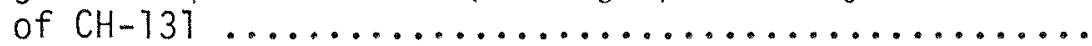

15. Average semi-quantitative spectrographic analys is

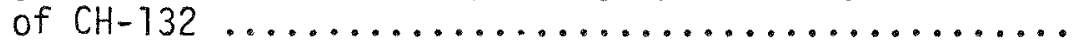

16. Average semi-quantitative spectrographic analysis

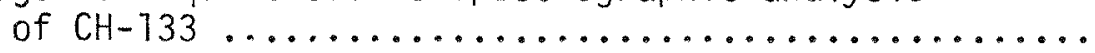

17. Average semi-quantitative spectrographic analysis

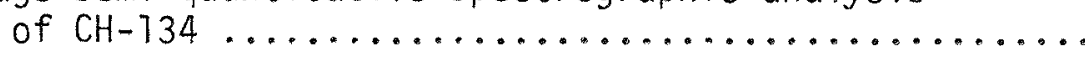

18. Average semi-quantitative spectrographic analysis of $2 \mathrm{HP}-170$ and $2 \mathrm{HP}-171$ 
19. Average baseline values for the Hanna UCG site ........ 92

20. Average stratigraphic unit correlation ............. 93

21. Hanna No. 1 - hole to hole correlation .............. 95

22. Local stratigraphic units - hole to hole correlation .... 98

23. Local stratigraphic units - within each hole ......... 100

24. Semi-quantitative spectrographic analysis by lithotype for $\mathrm{CH}-131$ and $\mathrm{CH}-132$, Hanna UCG site ............. 103

25. Semi-quantitative spectrographic analysis by lithotype for $\mathrm{CH}-133$ and $\mathrm{CH}-134$, Hanna UCG site .............. 104

26. Semi-quantitative spectrographic analysis by lithotype for average baseline values, Hanna UCG site ......... 107

27. Lithotype correlations for $\mathrm{CH}-131$ and $\mathrm{CH}-\mathrm{T32}$, Hanna UCG site ........................... 106

28. Lithotype correlations for $\mathrm{CH}-133$ and $\mathrm{CH}-134$, Hanna UCG site ............................ 107

29. Lithotype correlations of average baseline, Hanna UCG site ................................ 108

30. Analytical analysis of $\mathrm{CH}-133$, Hanna UCG site ......... 110

31. Analytical analysis of the Hanna No. 1 coal, Hanna UCG site .......................... 112 


$$
\begin{gathered}
\text { GEOLOGY OF THE HANNA FORMATION, } \\
\text { HANNA UNDERGROUND COAL GASIFICATION SITE, } \\
\text { HANNA, WYOMING }
\end{gathered}
$$

by

Robert L. OTiver and ATV D. Youngberg

\section{ABSTRACT}

The Hanna Underground Coal Gasification (UCG) study area consists of the SW $\frac{1}{4}$ of Section 29 and the $E_{\frac{1}{2}} \mathrm{SE}^{\frac{1}{4}}$ of Section 30 in Township 22 North, Range 81 West, Wyoming. Regionally, this is located in the coalbearing Hanna Syncline of the Hanna Basin in southeast Wyoming. The structure of the site is characterized by beds dipping gently to the northeast. An east-west fault graben complex interrupts this basic trend in the center of the area. The target coal bed of the UCG experiments was the Hanna No. 1 coal in the Hanna Formation. Sedimentary rocks comprising the Hanna Formation consist of a sequence of nonmarine shales, sandstones, coals and conglomerates. The overburden of the Hanna No. 1 coal bed at the Hanna UCG site was divided into four broad local stratigraphic units.

Analytical studies were made on overburden and coal samples taken from cores to determine their mineralogical composition. Textural and mineralogical characteristics of sandstones from local stratigraphic units $A, B$, and $C$ were analyzed and compared. Petrographic analyses were done on the coal including oxides, forms of sulfur, pyrite types, maceral composition, and coal rank. Semi-quantitative spectrographic and analytic geochemical analyses were done on the overburden and coar and relative element concentrations were compared. Trends within each stratigraphic unit were also presented and related to depositional environments. The spectrographic analysis was also done by lithotype.

\section{ACKNOWLEDGEMENTS}

Theodore $C$. Bartke made this study possible by administering funding from the Department of Energy Underground Coal Gasification Project. Associated Western Universities, Inc., also provided support through research stipends. The authors also wish to thank the many people involved in reviewing, editing, drafting, and typing of the manuscripts, whose work and assistance were invaluable to the completion of this report.

\section{INTRODUCTION}

HANNA UCG STUDY AREA

The Hanna UCG study area consists of the SW $\frac{1}{4}$ of Section 29 and the east half of the SE $\frac{1}{4}$ of Section 30 in Township 22 North, Range 81 West, Carbon County, Wyoming. Regionally, this is located in the coal-bearing Hanna Syncline of the Hanna Basin in southeast Wyoming (Figure 1 and 
Figure 2). The locations of the experimental burn sites are shown on Figure 2. The area is accessible by a service road joining U.S. Highway 30 approximately $\frac{1}{4}$ mile west of the U.S. Highway $30 /$ Wyoming Highway 72 junction south of Hanna, Wyoming.

The area is a mildly dissected prairie land with low vegetative cover consisting of sagebrush and buffalo grass. The area experiences frequent strong winds and has a cool continental/temperate climate consisting of long cold winters and short warm summers. The average precipitation is low, generally being between 10 and 15 inches/year.

\section{HANNA UCG PROJECT}

A number of underground coal gasification (UCG) experiments were conducted at the Hanna, Wyoming, Department of Energy, site from 1973 to 1979. The individual experimental sites are referred to as Hanna I, Hanna II (Phases $1,2,3$ ), Hanna III, and Hanna IV (a, b). All research was conducted under the direction of the Laramie Energy Technology Center with the intent of transferring the data and knowledge to the public domain for ultimate process commercialization by private industry. The UCG process has the potential to increase the utilization of coal reserves by obtaining energy from coals too deep and/or too thin to mine economically by conventional mining methods.

\section{PURPOSE AND SCOPE}

The purpose of this paper is to gather together all of the published and unpublished data and information on the geology of the Hanna UCG study area into one document. The paper will deal briefly with the regional geology of the Hanna Basin followed by a detailed analys is of the Hanna UCG site geology. This will include discussions on structure, joints and fractures, stratigraphy, geometry of deposits, mineralogy and petrology, and geochemistry of the overburden rocks and the Hanna No. 1 coal bed. The sections on structure and stratigraphy are dominantly a compilation of previously published data with some additional work. The mineralogy and petrology section contains both previously published work and new material. The geochemistry section is all original work.

\section{PREVIOUS WORK}

Early work on the Hanna/Carbon Basin area was done by Bowen in 1918 and Dobbin, Bowen, and Hoots in 1929. Later studies of the area were done by Knight (1961), Blackstone (1975), Brooks (1977), and Ryan (1977). These papers deal with the stratigraphy and depositional history of the Hanna/Carbon Basin area. Work was done on the depositional systems by Surdam and Stanley (1978) and Walker (1979). Glass and Roberts (1980) reported on the coals of the Hanna coal field. 


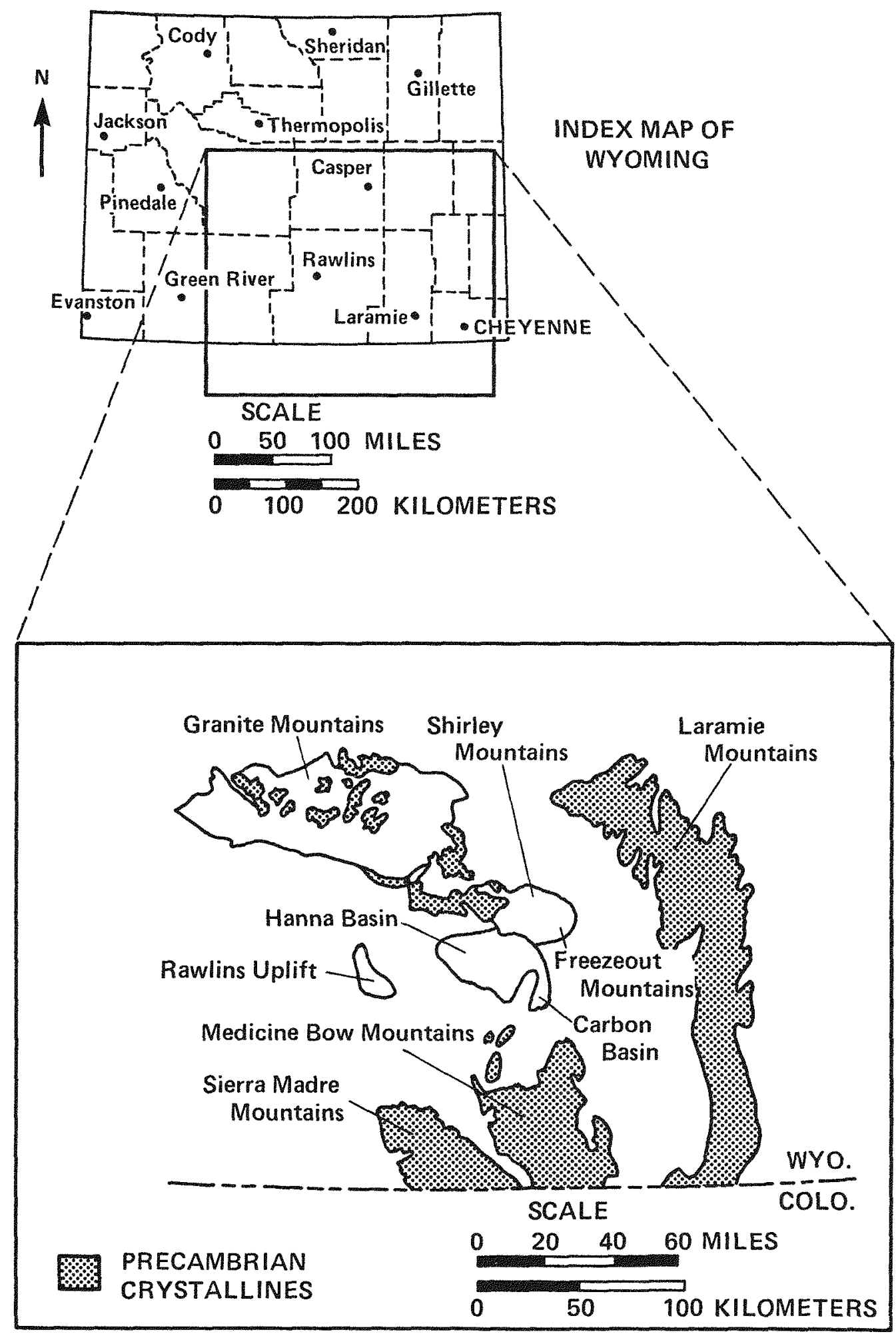

Figure 1. Generalized location map of the Hanna Basin and surrounding mountains and uplifts (modified from Ryan, 1977, after Craig, et a1., 1982). 


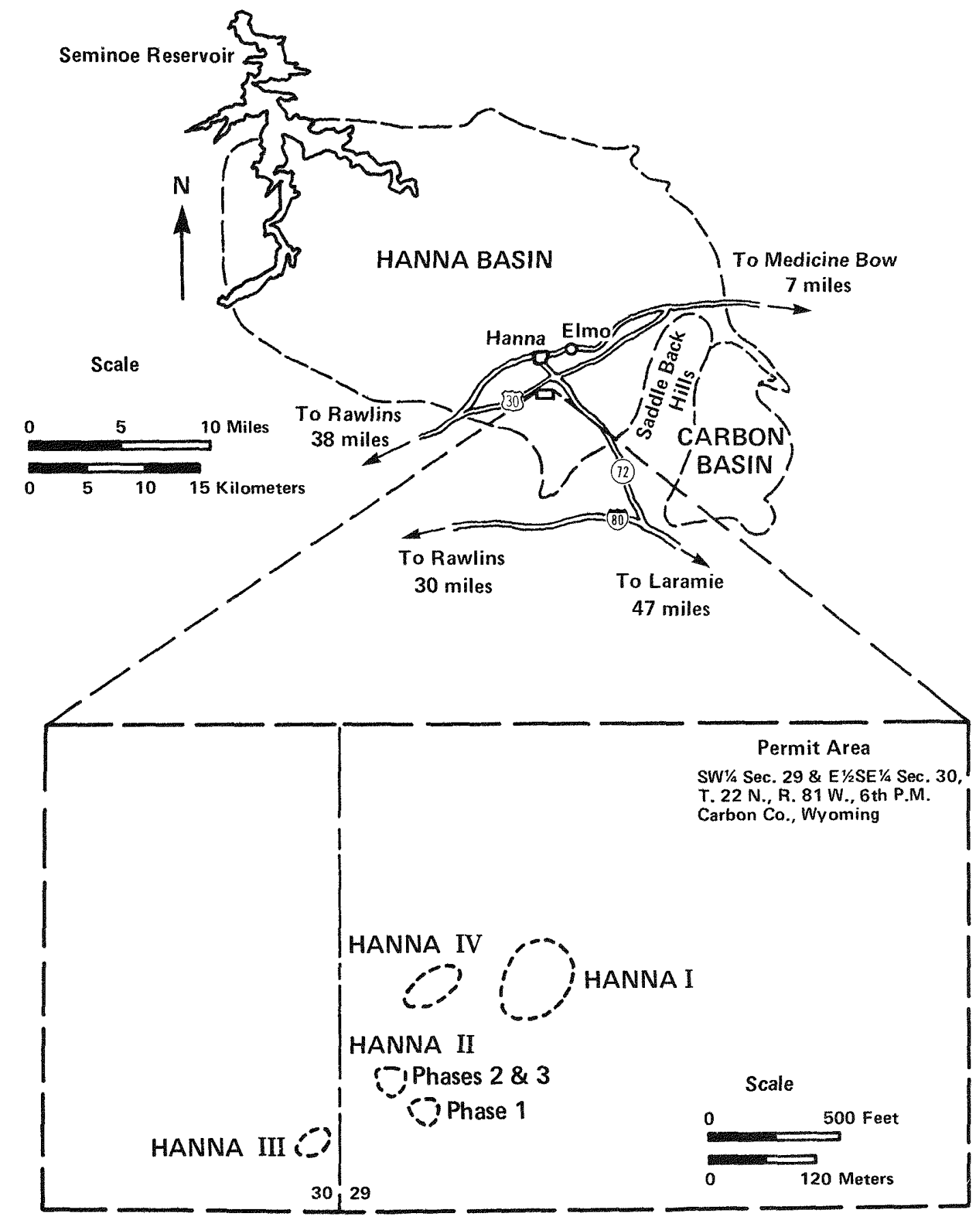

Figure 2. Location map of Hanna UCG site. 
The most significant site-specific studies relating to this paper are the various post-burn studies done on the Hanna UCG experimental burns. The Hanna II, Phase 1 experiment was evaluated by Youngberg, McClurg and Schmitt (1983). This paper evaluates the depositional environments, subsurface stratigraphy and postburn characteristics of the Hanna Formation. Youngberg and Sinks (1981) presented preliminary results for the postburn studies at Hanna II, Phases 2 and 3 . Information about the pyrometamorphic rocks and minerals from the experiment was obtained from Burns et a1. (1981, 1982). A petrographic study of unaltered and thermally metamorphosed coal from the site was presented by Youngberg (1981). Modeling of the Hanna II, Phase 2 experiment based upon postburn drilling was published by Levie et al. (1981). Details of the high resolution seismic survey at the Hanna II, Phases 2 and 3 site was presented by Youngberg et al. (1982). A detailed geologic study that included information from the Hanna II, Phases 2 and 3 experiments was given by Craig et a1. (1982) and Craig (1982). A comparison of the Hoe Creek UCG site with the Hanna UCG site using data from the Hanna II, Phases 2 and 3 post-burn studies was published by Ethridge et al. (1983). The Hanna III experiment was evaluated in a report by Youngberg, McClurg and Schmitt (1983). This current report contains a summary of all the above referenced work, and also contains additional information that had not been previously published.

\section{REGIONAL GEOLOGY}

\section{STRUCTURE}

The Hanna Basin and adjacent Carbon Basin are bounded by Laramideaged uplifts (Figure 1). To the north, a highland region comprised of the Freezeout, Shirley, and Granite Mountains parallels the axis of the Hanna-Carbon Basin complex. High granite peaks in the southeastern portion of the Granite Mountains are referred to as the Ferris and Seminoe Mountains. The Hanna Basin is separated from the ranges to the north by a high-angle reverse fault of large displacement. Movement along this fault likely began in the Upper Cretaceous prior to deposition of the Medicine Bow Formation and continued we 17 into Eocene time (Knight, 1961). The western margin of the Hanna Basin is defined by the Rawlins Uplift and the southern margin by the northern end of the northsouth trending Medicine Bow Mountains. The Hanna Basin is bounded on its eastern margin by the Saddleback Hills, a Laramide-aged anticline which appears to be a northerly extension of the Medicine Bow Mountains.

Numerous normal faults occur across the coal-bearing synclines of the area. These faults trend northwest-southeast with cross-faulting common. Faults often occur quite closely together and vertical displacements vary from a few feet to several hundred feet. Zones of closely spaced fractures are sometimes associated with these faults.

Much of the strata in the Hanna Basin are tightly folded. Several synclines exist in the basin with the outcrop of the Hanna No. 1 Coal Seam encircling the Hanna Syncline, a structure which plunges to the 
northeast. A structure contour map of the Hanna No. 1 Coal Bed is shown in Figure 3. Dip of the rocks vary from almost vertical along the northern edge of the basin to nearly horizontal in the centers of the synclines (Glass, 1980).

The location of the Hanna UCG site is in the southeastern portion of the Hanna Basin (Figure 2). In this region, strata strike to the northwest and dip to the northeast at an average of 3 (Youngberg et a 1., 1981). Several normal faults are present at the Hanna site which create local structural dips of up to $8^{\circ}$. Fault displacements are generaliy less than $40 \mathrm{ft}$., but may be as great as $50 \mathrm{ft}$.

\section{STRATIGRAPHY}

A general geologic map of the Hanna Basin area is shown in Figure 4. Three Upper Cretaceous-Tertiary formations deposited during structural evolution of the Hanna Basin are recognized in this region. These include the Upper Cretaceous Medicine Bow, Paleocene (Tertiary) Ferris, and Paleocene-Eocene (Tertiary) Hanna Formations (Ryan, 1977; Figure 5). Aggregate thickness of these deposits is approximate $7 y 21,000 \mathrm{ft}$. Each of these units was deposited in the intermontane subsiding Hanna Basin in continental environments including alluvial fan, fluvial, and swamp settings. Coal beds are common in all three lithologic units, and many have been extensively exploited by both underground and strip mining (GTass, 1972; GTass and Roberts, 1980). The entire stratigraphic sequence in the Hanna Basin represents the thickest accumulation of sediments in any wyoming basin.

Sedimentary rocks comprising the Hanna Formation consist of a sequence of nonmarine shales, sandstones, coals and conglomerates deposited after withdrawal of the cretaceous epicontinental seas from this area (Craig et a1., 1982). Coal appears throughout most of the Hanna Formation with thirty-two coal seams greater than five feet in thickness. While certain coals may be 20 to 38 feet thick, most coals are in the 5 to 11 feet thick range (Glass and Roberts, 1979). Glass and Roberts (1980) described the coal beds of the Hanna Mining District. Twentythree out of twenty-five persistent coals in that district at least locally equal or exceed 5 feet in thickness (Figure 6). Of these 23 coal beds, 8 exceed 20 feet in thickness (Bed No. REM 93, Hanna No. 1, Bed No. 80 , Bed No. 79, Bed No. 78, Hanna No. 2, Bed No. 76, and Hanna No. 5). The other coal beds are generally less than 12 feet thick. In places the thickest coals, Bed No. RME 93, Hanna No. 2, and Hanna No. 5, a 11 exceed 30 feet in thickness.

The Hanna gasification project utilized a coal bed in the Hanna Formation, the Hanna No. 1 coal bed. This coal seam has a 4 to 32 foot thickness range (Figure 7) with overburden ranging from zero to over 450 feet (Figure 8). 


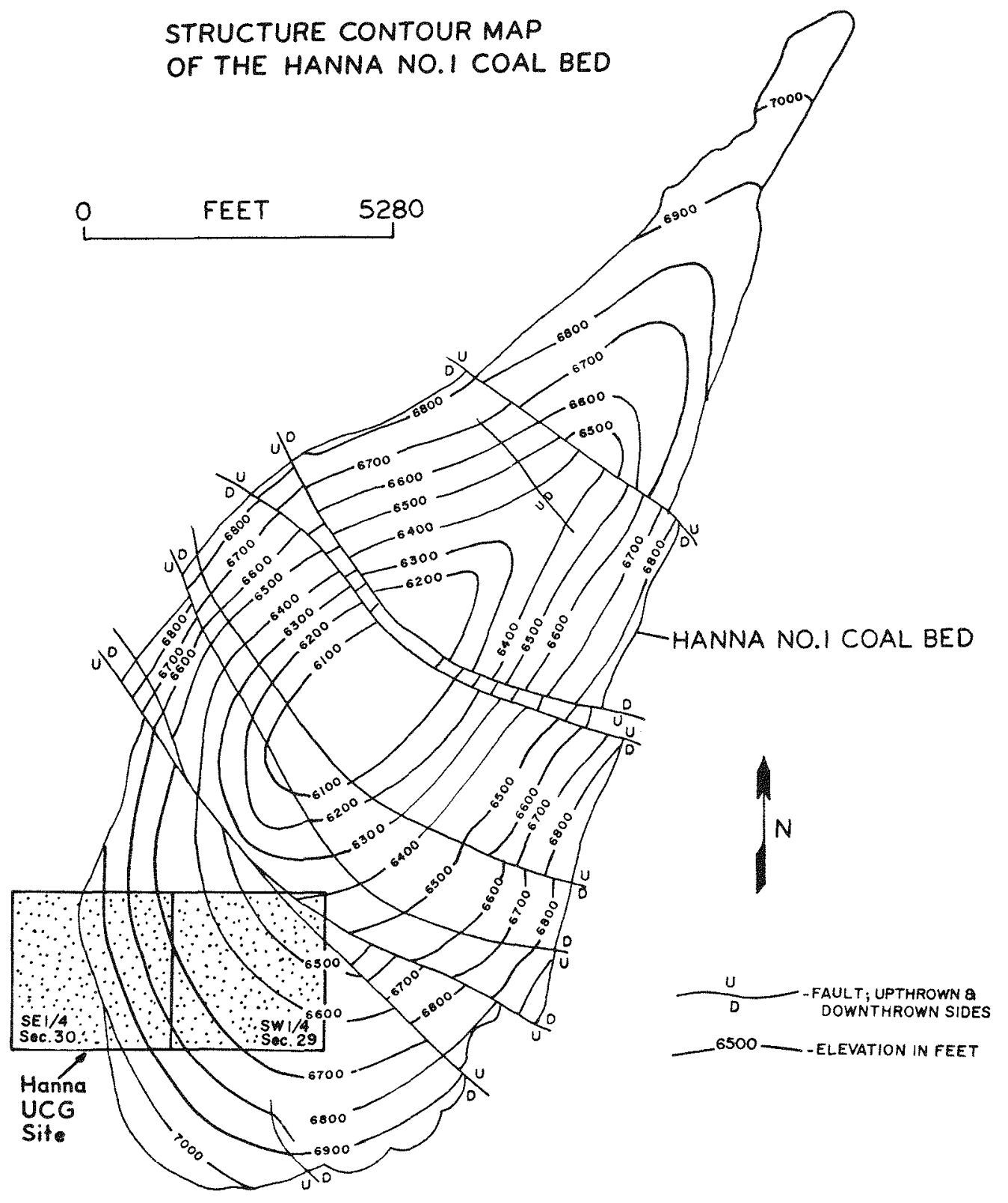

Figure 3. Structure contour map of the Hanna No. 1 coal bed (modified from Glass and Roberts, 1980). 


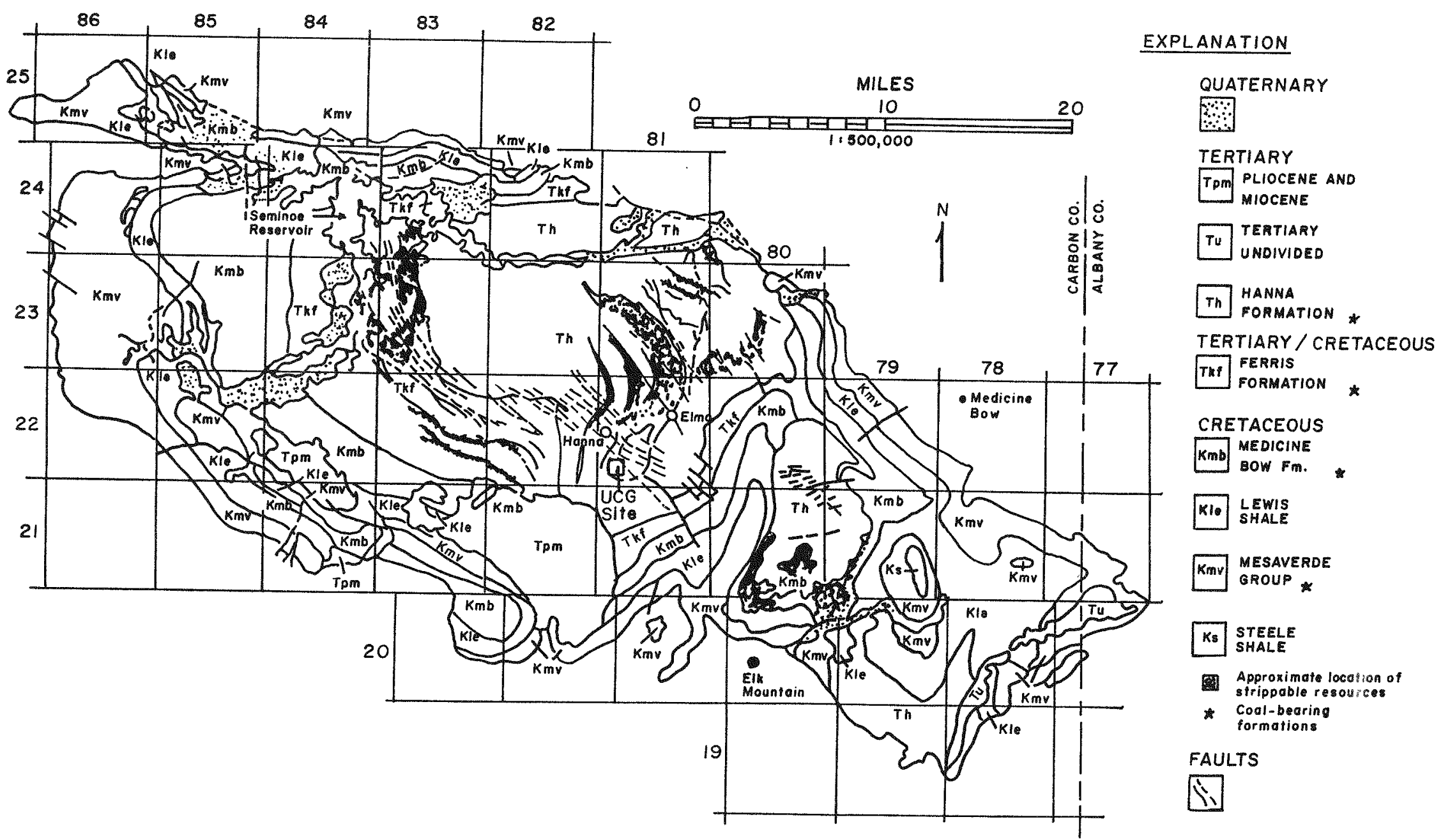

Figure 4. Geologic map of the Hanna Coal Field (modified from Glass and Roberts, 1980). 


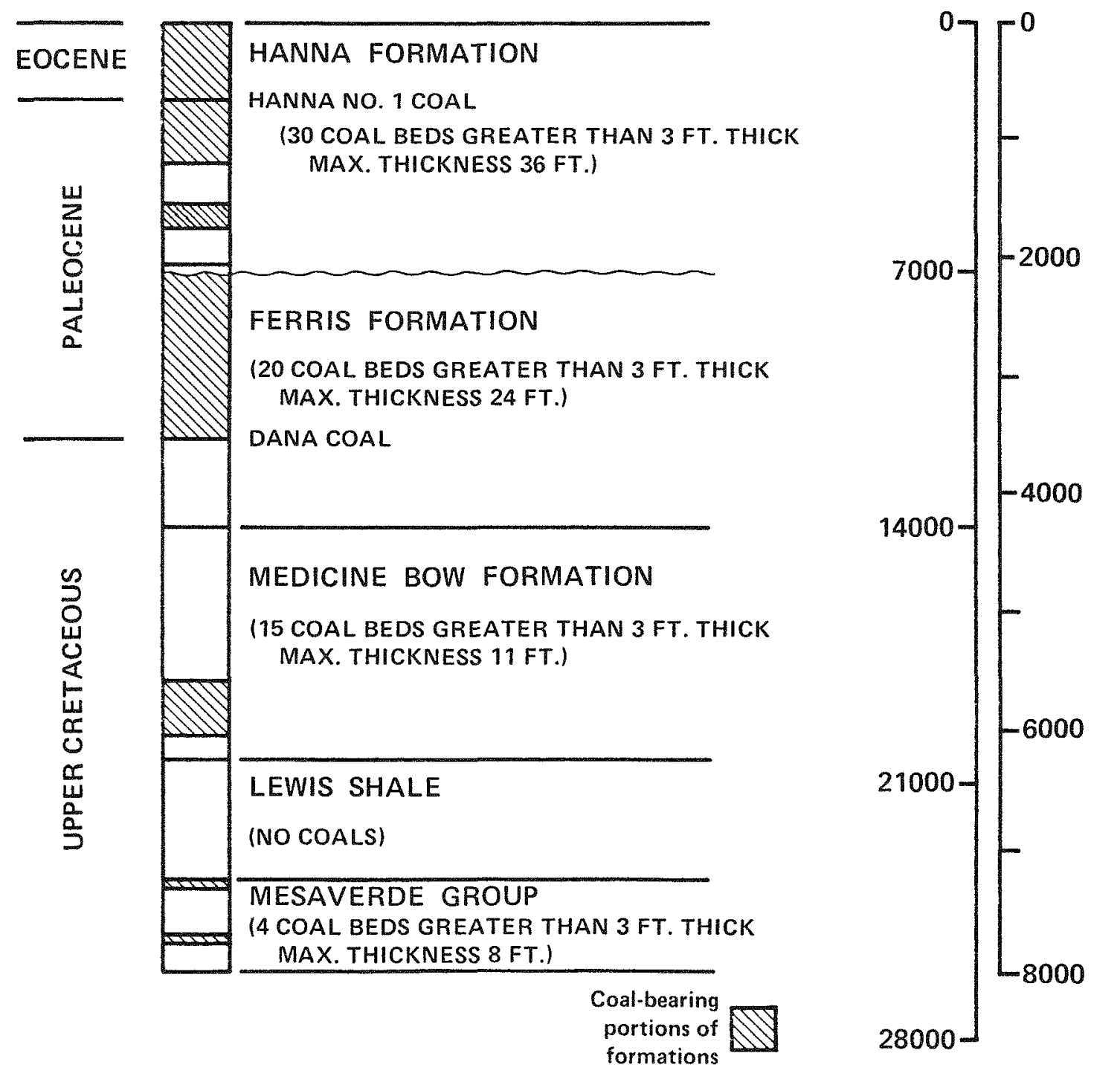

Figure 5. Upper Cretaceous and Lower Tertiary stratigraphy of the Hanna Basin (modified from Dobbin, 1929). 


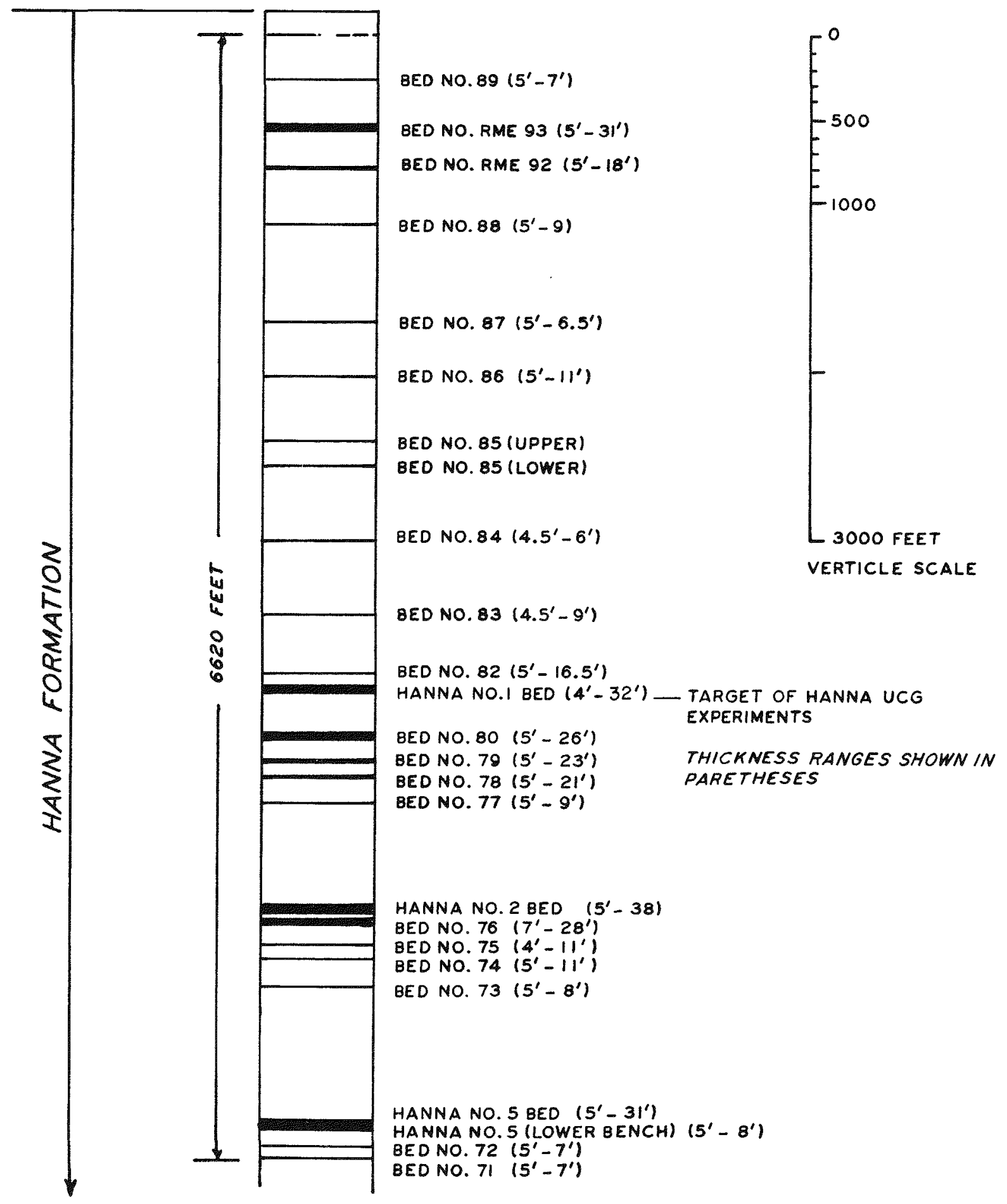

Figure 6. Coal nomenclature in the Hanna Mining District of the Hanna Coal Field (after Glass and Roberts, 1980). 


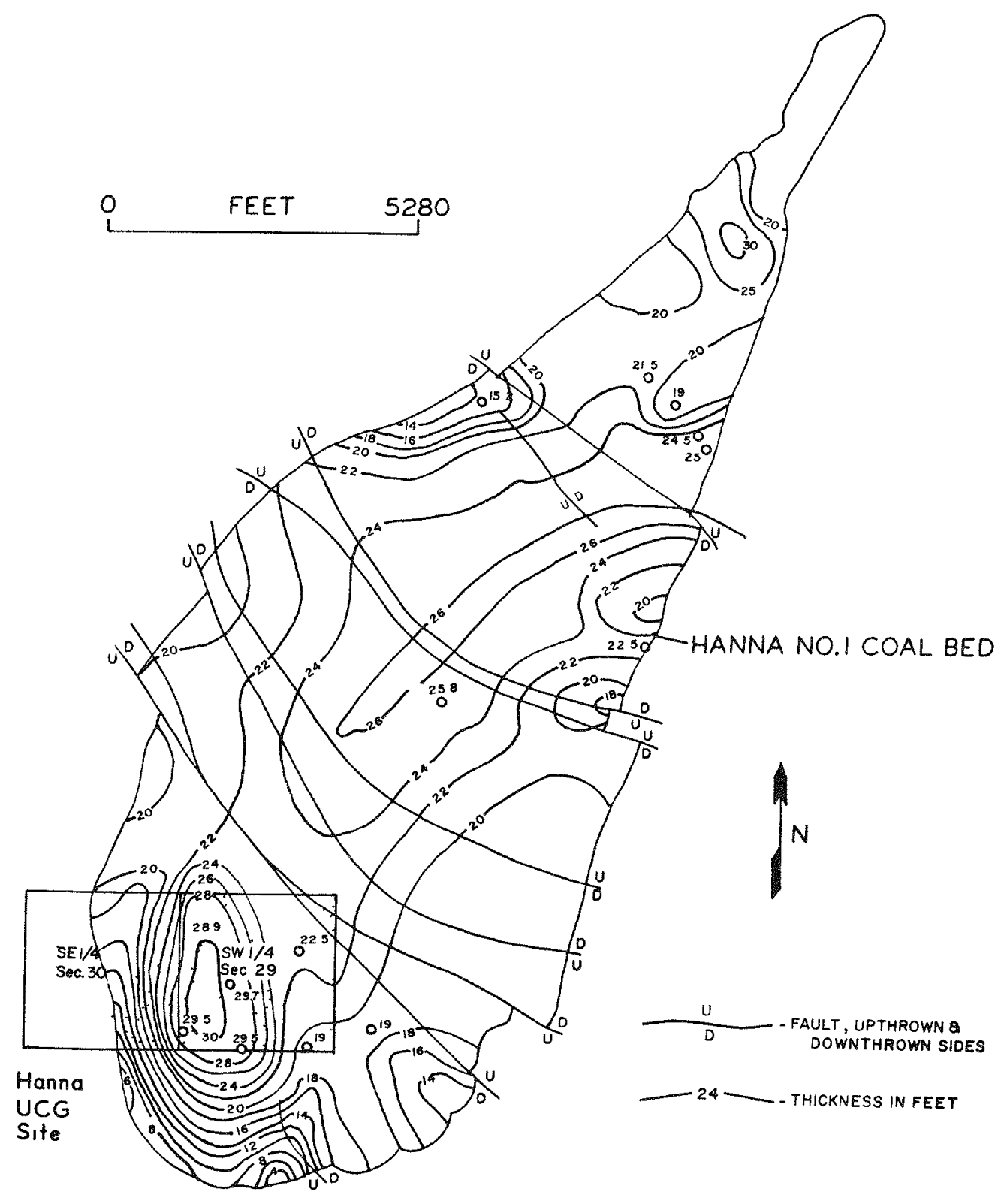

Figure 7. Isopach map of the Hanna No. 1 coal bed (modified from Glass and Roberts, 1980). 


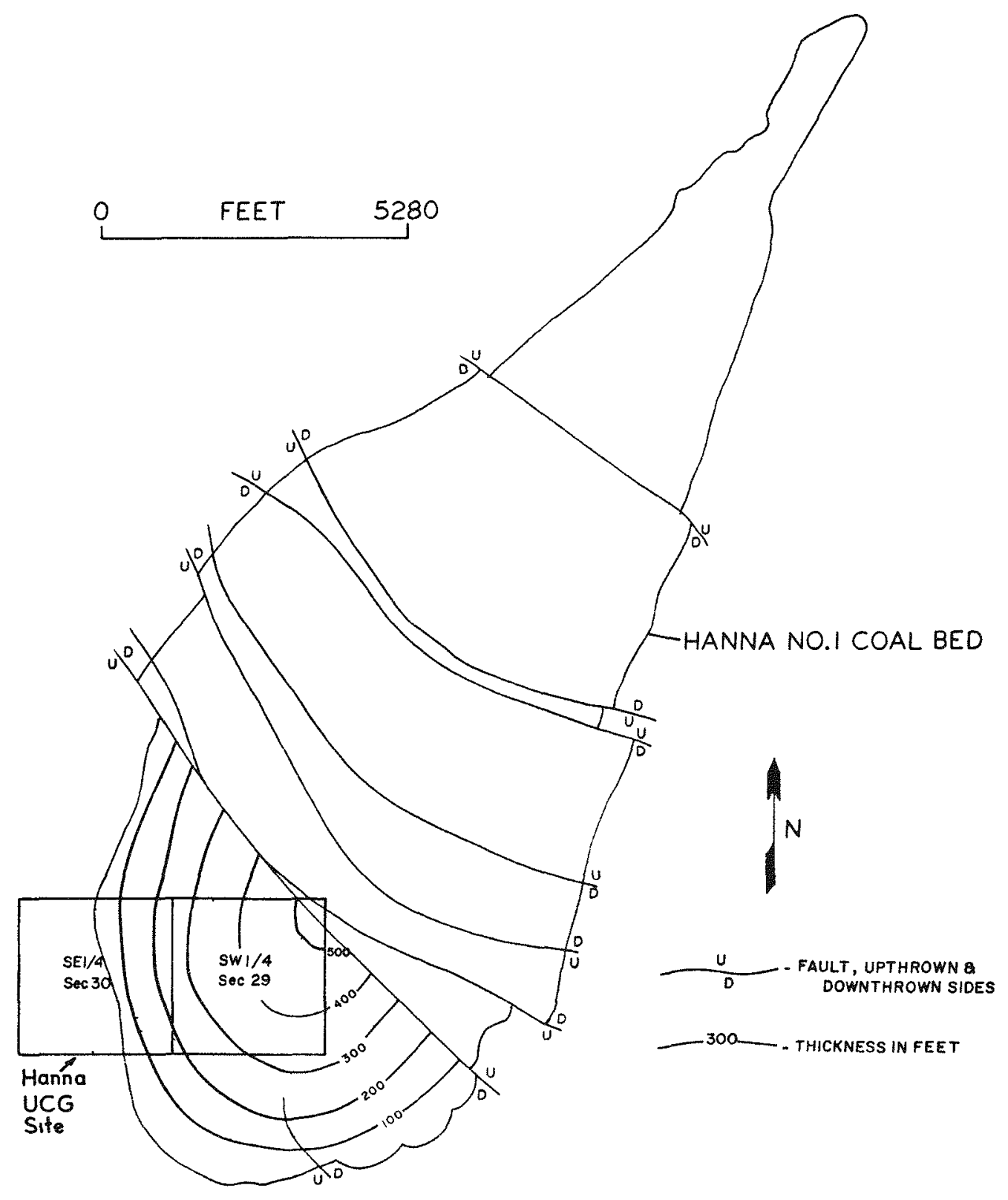

Figure 8. Overburden isopach map of the Hanna No. 1 coal bed (modified from Glass and Roberts, 1980). 
HANNA UCG SITE GEOLOGY

STRUCTURE

Folds and Faults

The study area is located southwest of the structural axis of the Hanna Basin. Rock units in the study area strike to the northwest and dip to the northeast with an average dip of $3^{\circ}$ as determined from a structure contour map on top of the Hanna No. 1 coal bed (Youngberg et a]. . 1981; Figure 9). A number of normal faults at the test site disrupt the local structural configuration and dip as illustrated by the structure contour map in Figure 9 and in the northeast-southwest structural crosssection shown in Figure 10. The fault system that trends west to east through the study area was found to be a graben complex with numerous antithetic faults (Youngberg et a1., 1981). This fault system has created local anticlinal structures (north-central portion of the study area, Figure 9) and structural dips of up to $8^{\circ}$ (southwestern portion of the study area, Figure 9). Displacements across these faults are generally less than $40 \mathrm{ft}$ but may be as high as $50 \mathrm{ft}$. A more recent interpretation of the site structure from seismic data acquired in 1983 was done by Berkman and Orange and is shown in Appendix $C$.

\section{Joints and Fractures}

Based on joint orientations taken at 32 different sites by Glass and Roberts (1980), four joint sets are recognized in the coals of the Hanna Basin:

$\begin{array}{lcc}\text { Set A } & 290-295^{\circ} & \left(\text { N. } 70-65^{\circ} W_{.}\right) \\ \text {Set B } & 320-330^{\circ} & \left(N .40-30^{\circ} W_{.}\right) \\ \text {Set C } & 23-25^{\circ} & \left(N .23-25^{\circ} E_{.}\right) \\ \text {Set D } & 60-70^{\circ} & \left(N .60-70^{\circ} E_{.}\right)\end{array}$

Figure 11 shows these joint measurements plotted on a rose diagram. The Hanna Formation coal readings were taken in the Hanna Mining District or in the eastern portion of the basin. Joint Set $A\left(290^{\circ}\right)$ is almost unrecognizable in the Hanna coals. This joint set and Joint Set $C$ comprise one orthogonal joint system in this area, as they are very nearly perpendicular to one another (Glass and Roberts, 1980). Joint Set $B\left(320^{\circ}\right)$, on the other hand, is obvious in the Hanna Formation coals. This joint set exhibits the same orientation as the predominant faulting in the basin. The existence of a second orthogonal joint system comprised by Set B and Set D is less convincing. Joint Set $C$ $\left(23^{\circ}\right)$ is the most often observed joint set of the four, and as mentioned earlier, this joint set and Jojnt Set A comprise an obvious orthogonal joint system. Joint Set $D\left(70^{\circ}\right)$ is less commonly noted but nonetheless obvious in coals of the area. 

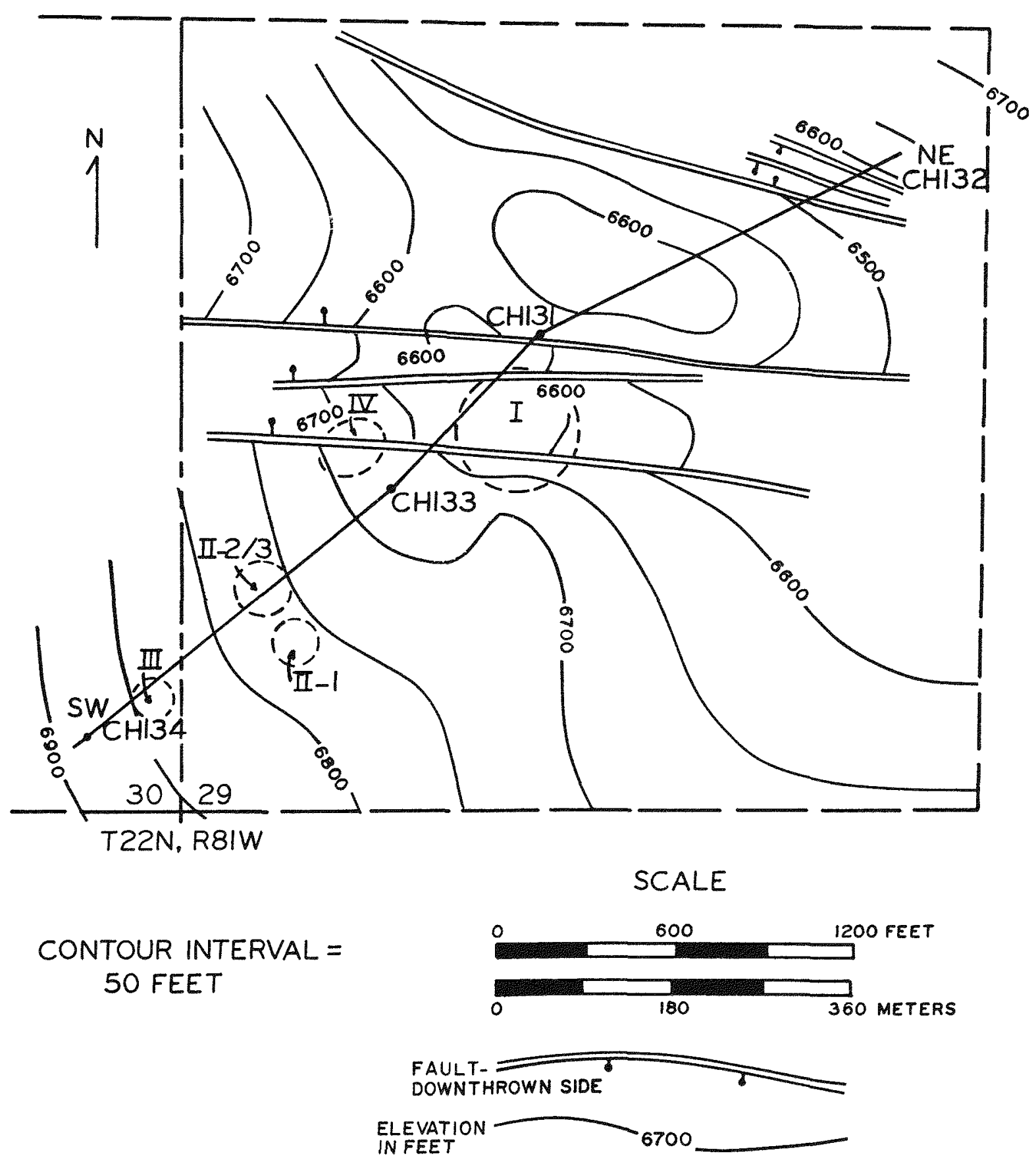

Figure 9. Structural contour map on top of the Hanna No. 1 coal bed (after Youngberg et a1., 1981). Note: structural contours in feet above sea level. SW-NE Tine is surface trace of cross section shown in Figure 10. 
SW

CHI34

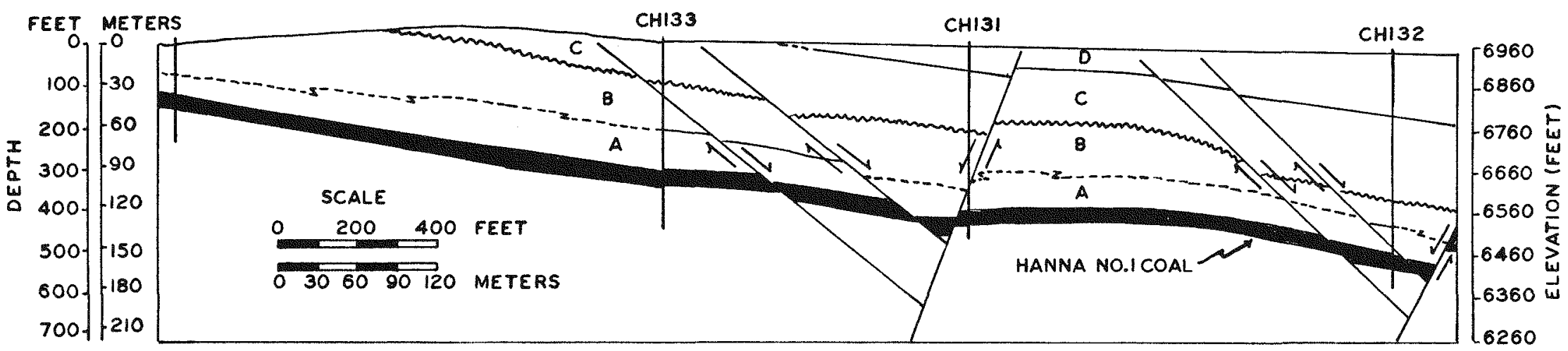

Figure 10. Generalized northeast-southwest structural cross section of the Hanna UCG area (after Craig et a1., 1982). (Location of section shown on Figure 9.) 


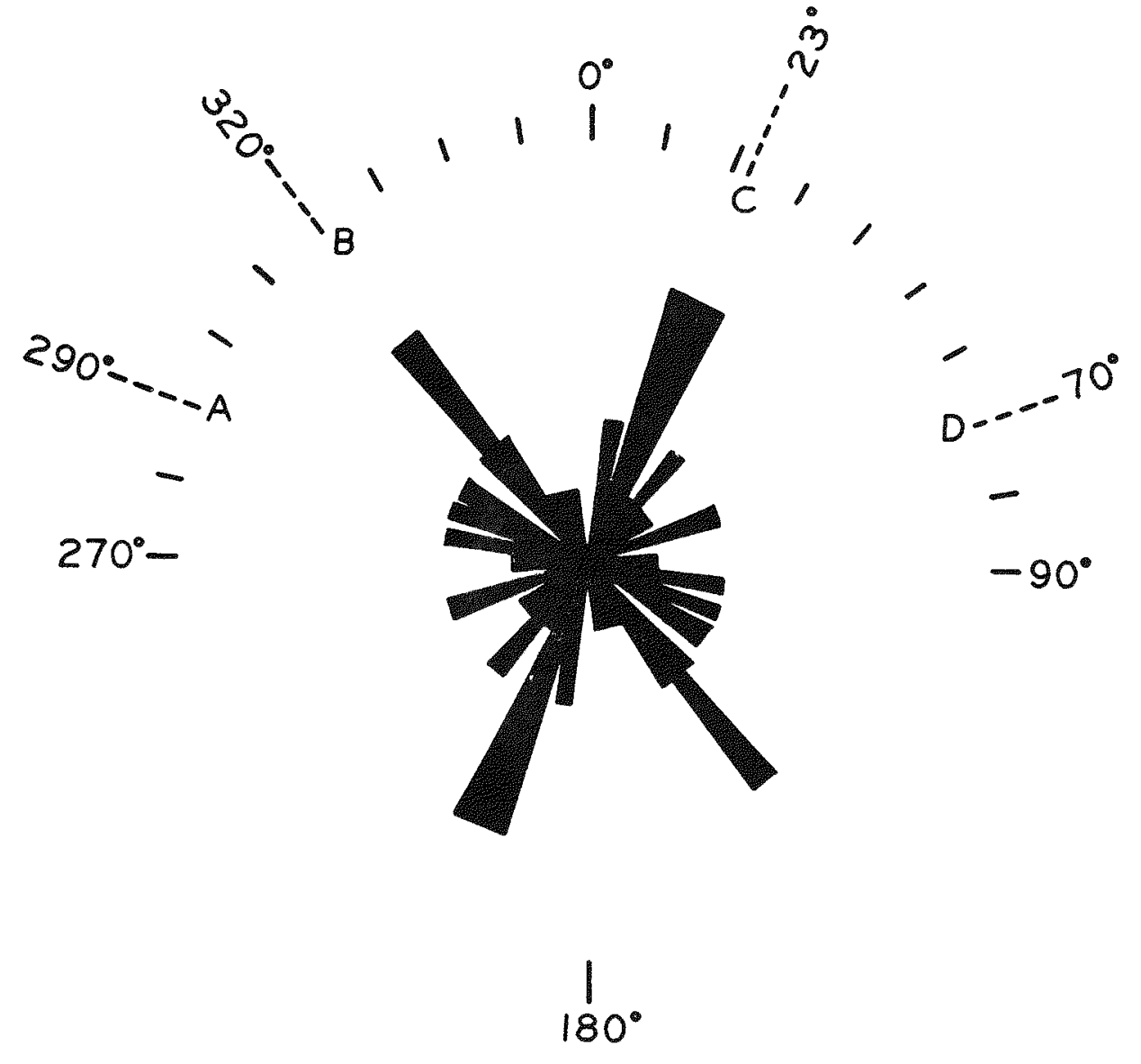

Figure 11. Joint sets in the coals of the Hanna Formation (after Glass and Roberts, 1980). 
Some joint sets, most notably Joint Set $C$ and to a lesser extent Joint Sets $A$ and $B$, might best be termed systematic joints (Nickelsen and Hough, 1967). These systematic joints are vertically persistent; they do not terminate at petrographically different zones in the coal or at bedding planes within the coal. Instead, they persist for many inches to as much as several feet downward through the coal. They also do not terminate lateraliy against joints of other orientations but they cut through the other joint sets, exhibiting lateral extents on the order of many inches to several feet. In contrast, the less well developed joint sets terminate against the more persistent and pronounced systematic joints and seldom cross differing coal lithotypes or bedding planes in the coal. These joints are likened to the nonsystematic joints of Nickelsen and Hough (1967).

According to Glass and Roberts (1980), lithologies also affect the orientation of joints. Atthough not enough measurements were taken for a true comparison, the strikes exhibited by most joint sets vary as they pass through different $7 i$ thologies. This phenomenon is much more pronounced when the joint orientations found in coals are compared with the orientations of the same joint sets in overlying sandstones and shales. Glass (1972) observed as much as a $2.5^{\circ}$ shift in orientation as a joint passed from one Tithology to another.

Joint spacing also varies considerably with lithology. Glass and Roberts (1980) state that, generally speaking, joints in sandstones are measured in terms of feet or yards apart; joints in shales are best thought of in feet or inches; and spacing in coals is more on the order of inches or centimeters.

Fractures in coal are important to consider when discussing UCG experiment areas since these determine, to some extent, the gas bearing capacity gas permeability, and fluid flow in coals. Ammosov (1963) discusses three basic genetic types of fractures in coal layers: 1) Endogenetic, 2) Exogenetic, and 3) Hypergenetic. Table 1 lists these types with accompanying descriptions of geologic factors and nature of forces involved.

Table 1 - Classification of fractures in coal.

\begin{tabular}{|c|c|c|c|c|}
\hline TYPE & SUBTYPE & $\begin{array}{l}\text { GEOLOGIC } \\
\text { FACTORS }\end{array}$ & $\begin{array}{l}\text { NATURE } \\
\text { OF FORCES }\end{array}$ & PROCESSES \\
\hline Endogenetic & & Metamorphism & Tension & $\begin{array}{l}\text { Inner contraction } \\
\text { of the coal mass }\end{array}$ \\
\hline Exogenetic & $\begin{array}{l}\text { Cleavage } \\
\text { Rupture }\end{array}$ & Tectonics & $\begin{array}{l}\text { Compression } \\
\text { Tension }\end{array}$ & $\begin{array}{l}\text { Deformation of the } \\
\text { coal mass caused by } \\
\text { external factors }\end{array}$ \\
\hline
\end{tabular}

Hypergenetic

Weathering Tension External forces 
The maximum permeability of layered coal coincides with the direction of the main endogenetic fracture system and of the wrench fractures of exogenetic origin (Ammosov, 1963). The presence of exogenetic shear fractures formed by compression witl lower permeability.

\section{Hanna No. 1 Coal Bed Core Study}

A detailed study on the directional properties of Hanna Coal was conducted by Pasini et al (1972). In order to collect data necessary to support field operations to gasify coal in place, an oriented core was obtained by LETC and sent to Morgantown Energy Research Center for study. The primary purpose in conducting directional property studies is to determine the dominant direction in which gases generated and/or released by heat during the combustion process would move, and to subsequently drill wells in the most advantageous places to capture these liberated gases. Since the directional flow properties of the coal are a result of the interaction of a number of physical properties, several types of measurements were conducted by Morgantown on the oriented coal core. These measurements included orientation of joint strikes, directional permeability measurements of both whole core and smaller pieces, directional tensile strength, point-load induced failure, and directional sonic velocity tests.

\section{Joint Measurements}

Six readily identifiable joint sets are found in the coal at the Hanna site. Three of these directions are quite dominant over the others. One is prominent among the three dominant joint sets. The joint sets in order of the apparent prominance are set $1, N 60$ $68^{\circ} \mathrm{E}$; set $2, N 20-30^{\circ} \mathrm{E}$; and set $3, \mathrm{~N} 76-85^{\circ} \mathrm{W}$. The diagram in Figure 12 illustrates azimuth versus frequency of joints mapped in the oriented core. (Note the pattern is similar but not identical to that shown in Figure 11.) Data from sections of the core in which the orientation was questionable was omitted in compiling this diagram. The photograph in Figure 13 illustrates the natural joint system observed in the oriented core. The relationship between the dominant direction of faulting interpreted from seismic data $\left(N 68^{\circ} \mathrm{W}\right.$ and $\mathrm{N} 88^{\circ} \mathrm{W}$ ) and the dominant direction of joigting observed in the Hanna No. 1 c8al oriented core samples ( $N 65$ E followed by $N 20^{\circ} \mathrm{E}$, and $N 80^{\circ} \mathrm{W}$ ) is shown in Figure 14 . This figure shows that the joint set trending $N 20^{\circ}$ E is nearly perpendicular to the fault directions found in the northeast part of the study area ( $\mathrm{N} 68^{\circ} \mathrm{W}$ ) and the joint set trending $\mathrm{N} 80^{\circ} \mathrm{W}$ is nearly parallel to the fault directions found in the central part of the study area $\left(\mathrm{N} 88^{\circ} \mathrm{W}\right)$. This tends to support an exogenetic origin for jointing at the Hanna UCG site. The joint set which trends $\mathrm{N} 65^{\circ} \mathrm{E}$ is nearly perpendicular to the regional trend of faulting visible on the surface of the Hanna Basin. 


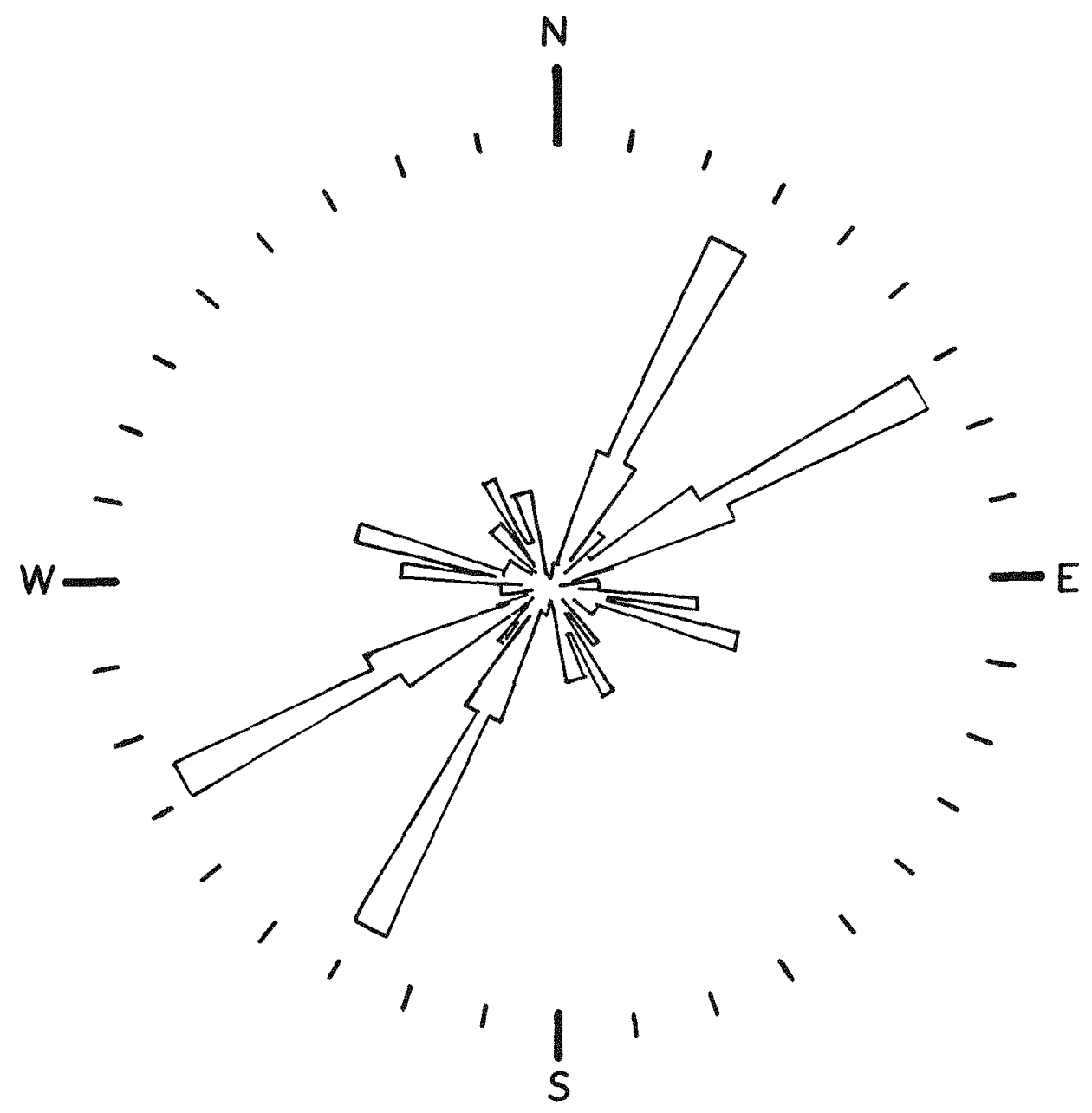

Figure 12. Azimuth versus frequency plot for all joints measured in oriented core from Hanna No. 1 coal seam (after Pasini et a), 1972). Scale: $1^{\prime \prime}=8$ percent. 


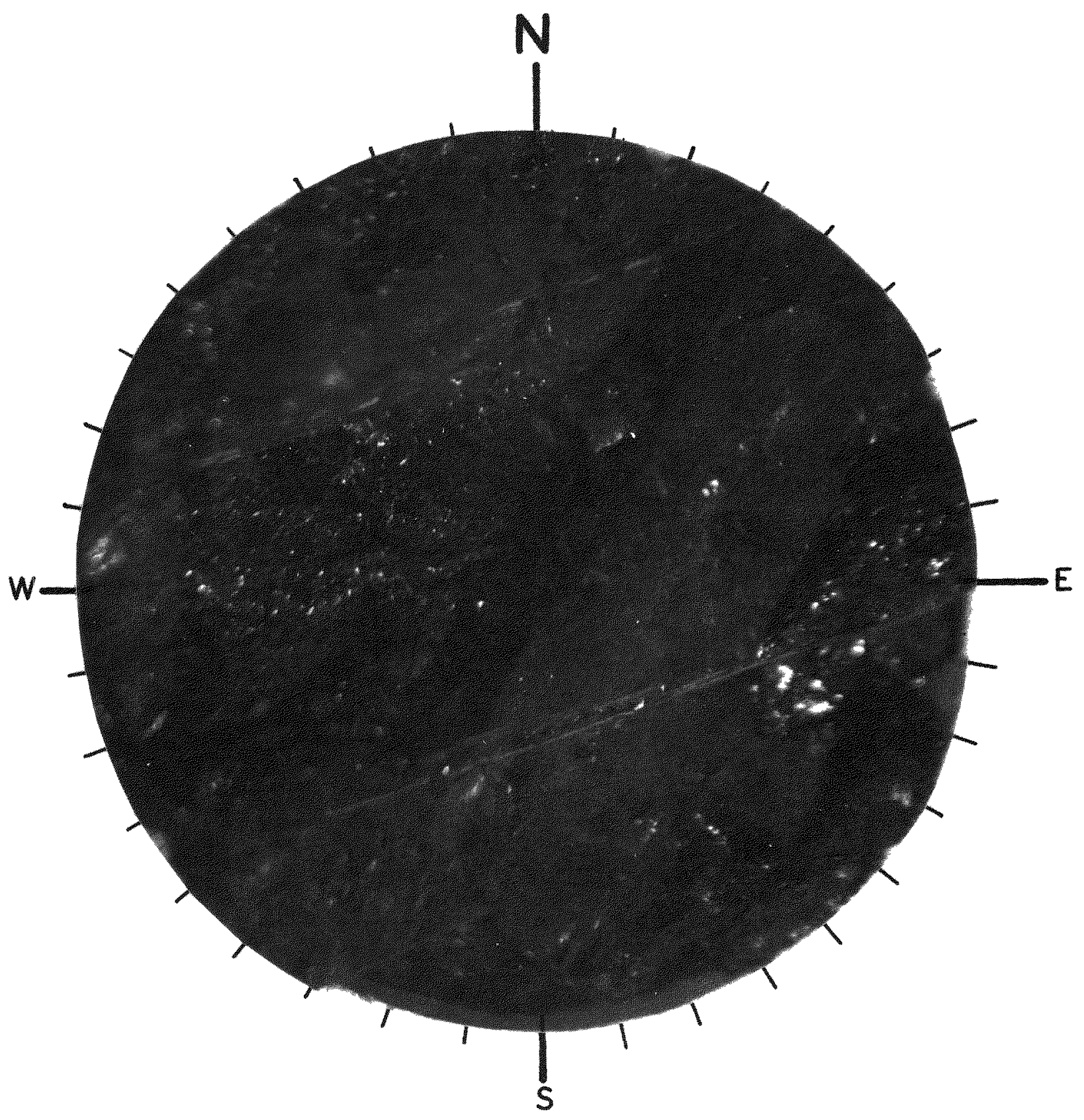

Figure 13. Photograph of oriented core from $\mathrm{CH}-2$, Hanna UCG site. 


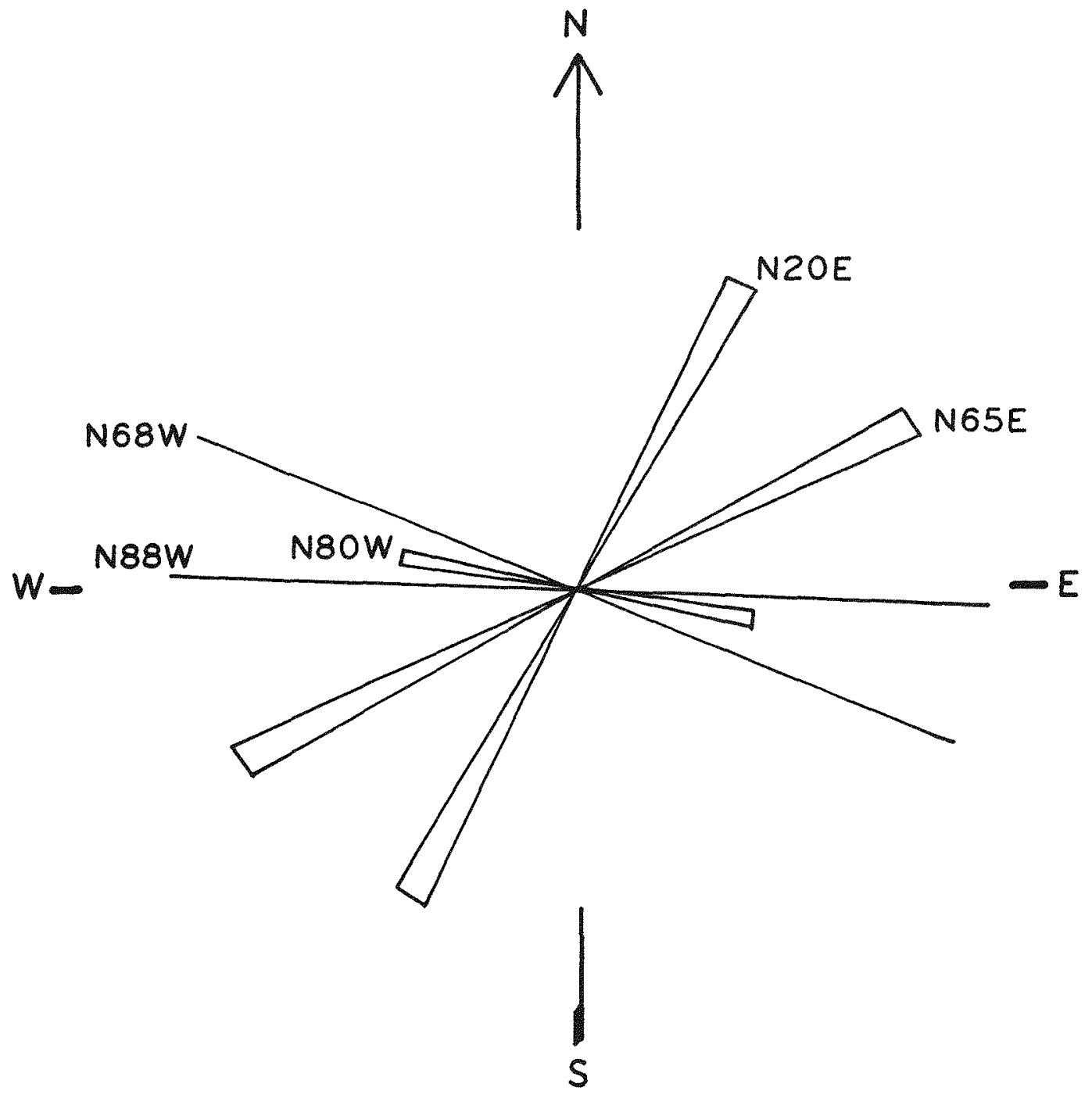

Figure 14. Diagram relating the dominant joint directions ( $N 65^{\circ} \mathrm{E}$, $\mathrm{N} 20^{\circ} \mathrm{E}$, and $\mathrm{N} 80^{\circ} \mathrm{W}$ ) to the dominant directions of fauiting $\left(\mathrm{N} 68^{\circ} \mathrm{W}\right.$ and $\mathrm{N} 88^{\circ} \mathrm{W}$ ). 
2. Other Measurements

Directional permeability measurements show three maximum trends which in order of importance are: $N 25-30^{\circ} \mathrm{E}, \mathrm{N} 40-45^{\circ} \mathrm{E}$, and $\mathrm{N} 25-30^{\circ} \mathrm{W}$. The resultant vector of directional permeability is interpreted to be approximately $\mathrm{N} 30^{\circ} \mathrm{E}$. Directional tensile strength measurements on sandstones above the coal indicate three directions of weakness in which failure might occur, or in which jointing and fracturing is now dominant. These are $\mathrm{N} 30^{\circ} \mathrm{W}, \mathrm{N} 55^{\circ} \mathrm{W}$, and $N 30^{\circ} \mathrm{E}$. The dominant of these two $N-W$ trends is believed to be $N 30^{\circ} \mathrm{W}$. This is the predicted direction of induced hydraulic fracture orientation if the horizontal stress component differences are large enough (more than 250 psi) to exert positive control. Should the horizontal stresses be nearly equal, then the direction of hydraulically induced failure could be controlled either by jointing (as in point-load failure tests) or directional permeability. In either case it would either be $N 30^{\circ} \mathrm{E}$ or $\mathrm{N} 60^{\circ} \mathrm{E}$. Ultrasonic travel time measurements in the coal indicate open fractures dominantly in two directions. One of these directions $\left(\mathrm{N} 60^{\circ} \mathrm{E}\right.$ ) is partially filled with calcite material and apparentiy reduces the flow capacity in that direction. Minor calcite filling was noted in $\mathrm{N} 30^{\circ} \mathrm{W}$ joints (Pasini et al, 1972).

The accuracy of measurements conducted on the oriented core could have a range of $\pm 5^{\circ}$ since those are the values of accuracy established for the core orientation technique. The good correspondence between core jointing and surface jointing and faulting would confirm these values. There is generally good agreement $\left( \pm 5^{\circ}\right)$ between the trends indicated by the various measurement techniques. All seem to point to the effects of jointing in the coal and roof rock as important factors to be considered in project planning. These tests could be misleading in that stresses acting on the coal in place may tend to enhance flow in another direction. At least the trends which may have considerabie effects on the results of field in-place gasification have been identified and can be utilized in planning well locations (Pasini et al, 1972).

\section{STRATIGRAPHY}

\section{Hanna Formation - General}

The Hanna Formation was named by Bowen (1918) from exposures north and west of Hanna, Wyoming. The formation contains interbedded sandstones, shales, conglomerates and coals, and ranges in thickness from $6800 \mathrm{ft}$ in the Hanna Basin to less than $500 \mathrm{ft}$ in the Laramie Basin (Blackstone, 1975). The greater thickness of Hanna strata in the Hanna Basin likely reflects more continuous deposition during late Cretaceous through early Eocene time. Conglomerates are typically comprised of detritus derived from erosion of $70 \mathrm{cal}$ highlands, including granite, quartzite, chert, and Mesozoic rock fragments. Massive Hanna conglomerates frequently grade into thick cross-bedded coarse-grained feldspathic sandstones which often form ledges. Thinner, finer-grained, less-resistant sandstones are also present. Hanna sandstones are usually broadly lenticular 
(Ryan, 1977). Shale units contain abundant plant remains, freshwater gastropods, bivalves, ostracods, and vertebrate bone fragments (Dobbin et a1., 1929). Detailed descriptions of measured surface sections are provided by Dobbin et al. (1929).

Deposition of Hanna strata in terrestrial environments has been suggested by several workers. Ryan (1977) interprets the Hanna sandstones as fluvial in origin. In a study of the Hanna Formation in the Carbon Basin, Brooks (1977) recognizes both braided and meandering channel depositional settings for conglomerates and sandstones and a meandering stream floodplain setting for shales and coals. In a more detailed study, Craig et al. (1982) analyzed cores from the Hanna UCG site, recognizing braided and meandering river channel, meandering river floodplain, and lacustrine depositional settings.

Paleocurrent analysis of Hanna fluvial sandstones reveal that the Granite Mountains to the north provided most detritus during Hanna deposition, with the Freezeout Mountains serving as a less important source (Ryan, 1977). The Medicine Bow Mountains to the south provided little clastic material.

\section{Local Stratigraphic Units}

The Hanna UCG site stratigraphic units and their depositional environments are discussed in the following paragraphs. The target of the Hanna UCG site is the Hanna No. 1 coaT seam. The Hanna Formation overburden in this area may be grouped into four broad 1ithologic units on the basis of sedimentary structures, grain size, texture and fauna? content. These Tithologic variants have been informaliy named Units $A$, $B, C$ and $D$ with $A$ being the oldest (Craig et al., 1982) (Figure 15).

Hanna No. 1 Coal Seam

The Hanna No. 1 coal seam consists of deposits of a poorly drained swamp in the flood plain of a fluvial system. The high ash content of the Hanna No. 1 coal seam suggests a large amount of clastic material that probably came from fluvial sources.

Unit A

Unit $A$ is found directly above the Hanna No. 1 coal seam and consists of siltstones and fine-grained sandstones with lesser amounts of claystones. The unit contains numerous coarsening-up sequences. The typical sequence starts with claystone at the base and coarsens upward to siltstone and then fine-grained sandstone overlain by claystone of the next sequence. Primary sedimentary structures found in the sandstones and siltstones are ripple drift cross-stratification (often burrowed) and high-angle foreset beds (often contorted by slumping)(Figure 16). The claystones are finely laminated and often contain bands of siderite. Bioturbation is common throughout the claystones and some gastropod she11s have been found (Craig et a1., 1982). 


\section{LITHOLOGY LITHOLOGIC UNITS \\ AND \\ AND}

DEPTH STRUCTURES INTERPRETATIONS

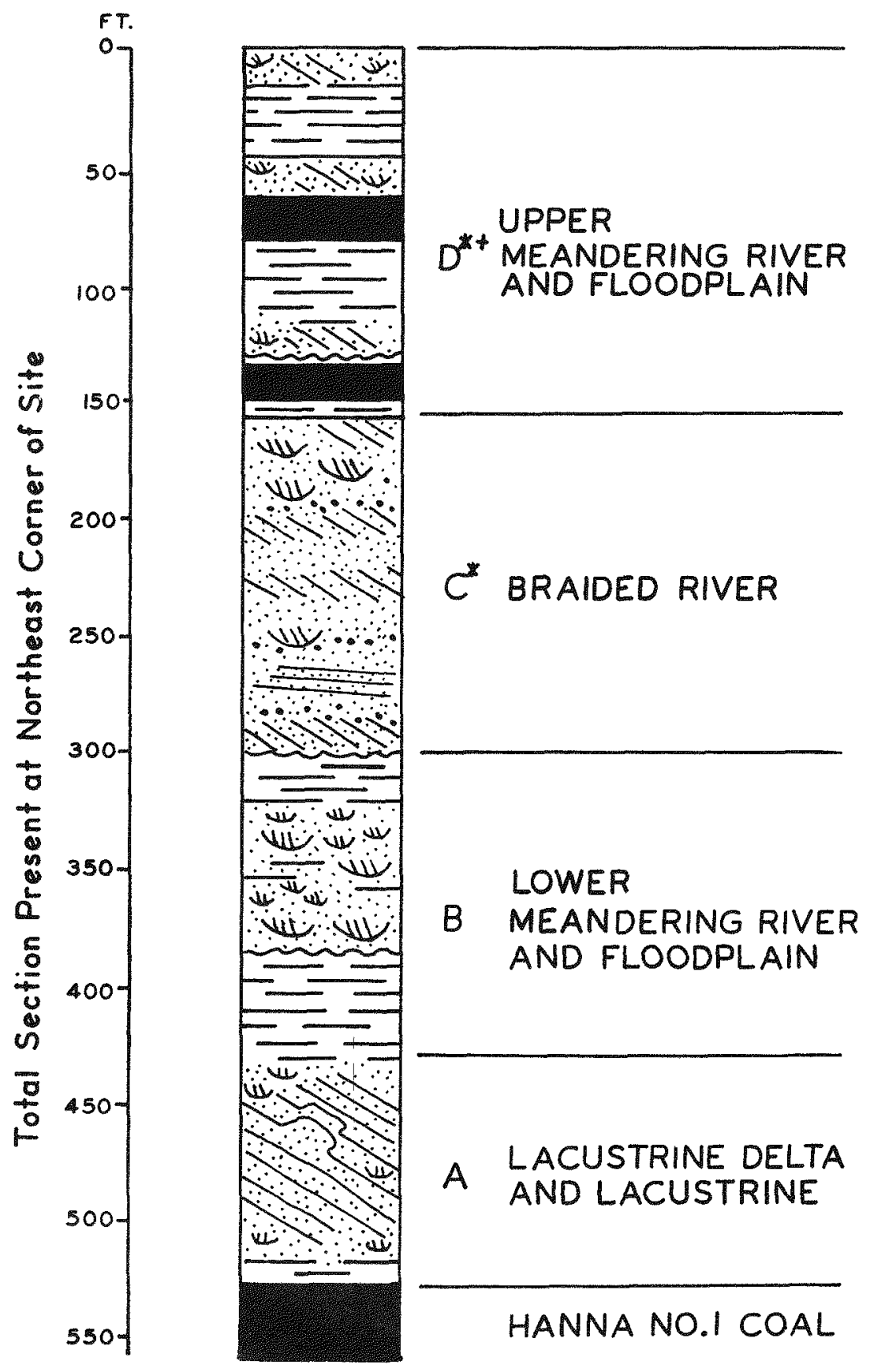

Figure 15. Subdivision of the overburden of the Hanna No. 1 coal bed at the Hanna UCG site (after Craig et al., 1982). *- Not present at Hanna UCG III +- Not present at Hanna UCG II or Hanna UCG IV. 

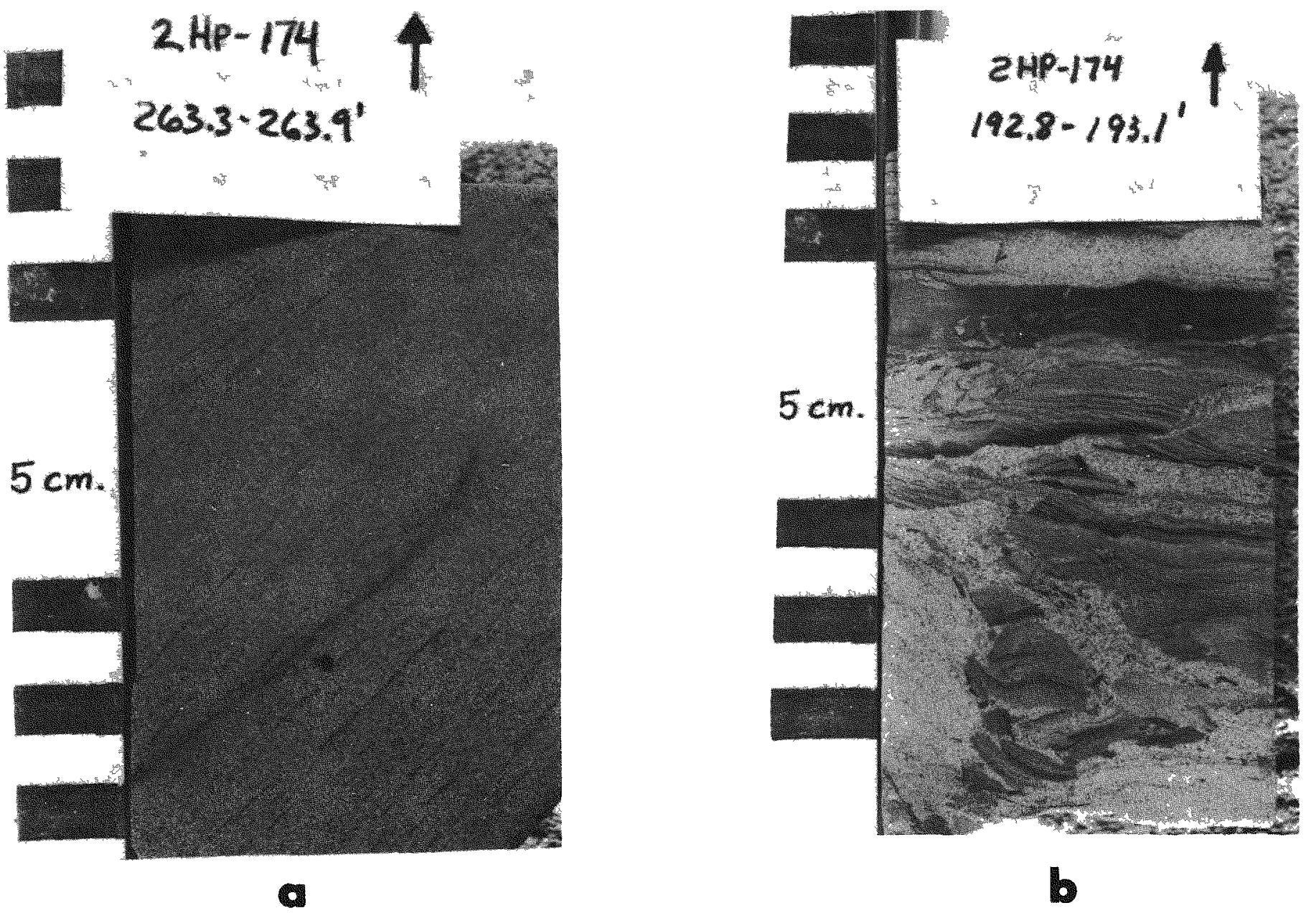

Figure 16. Core photographs from Unit A: a) high angle foreset beds; b) contorted and slumped beds. 
The olive-gray, finely-laminated claystones interbedded throughout the unit were probably deposited in a lacustrine environment. This is suggested by the dark highly organic and laminated nature of the claystones and the shells of freshwater mollusks that have been found in some cores.

The climbing ripple-stratified sandstones and siltstones were deposited in a lacustrine delta. As the delta prograded into the lake, sandstones were deposited in high-angle foreset beds. Evidently the delta fill was not continuous because of the interfingering of deltaic sandstones and lacustrine claystones. During periods of rapid deposition from heavy runoff or floods, the ripple drift or climbing ripple stratification was formed. During normal flow the lacustrine processes and deposition of laminated clays occurred. The interbedding could also have been formed by delta lobe switching (Craig et al., 1982).

Unit $B$

This unit consists primarily of olive-gray to olive-black mudstones and carbonaceous shales. Finely-laminated claystones similar to those in Unit $A$ are occasionally found. Most of the primary bedding has been destroyed by rooting and there is an abundance of organic partings and occasional coal lenses. Interspersed throughout the finer-grained rocks are isolated fine-grained to very fine-grained sandstone bodies.

These lenticular sandstone bodies show a fining-upward trend in grain size from fine-grained to very fine-grained sandstone near the top. There is also a vertical decrease in the size of bedform sedimentary structures from trough cross-bedding to ripple cross-stratification and the upper contacts are gradational with overlying shales. The basal contacts are erosional and usually overlain by a clay clast conglomerate.

The very fine-grained sandstone bodies are tabular in cross section and are rarely over $5 \mathrm{ft}$. thick. They display a vertical increase in grain size from muddy siltstone to very fine-grained sandstone. Sedimentary structures are mostly ripple drift cross-stratification with occasional occurances of trough cross-stratification (Figure 17). The lower contacts are gradational with underlying mudstones and shales. The upper contacts are sharp with the overlying shales and show evidence of rooting.

This unit was probably deposited by a meandering river and flood plain system following lake infilling and abandonment of the lacustrine delta of Unit A. Quiet water environments would have formed the carbonaceous shales, mudstones, and claystones.

The dark olive-gray organic mudstones and carbonaceous shales were deposited in poorly drained swamps similar to the formation of the Hanna No. 1 coal seam. Overbank flooding was probably common because of the abundance of clastic materials that occur within the deposits. The lighter-colored gray mudstones that occur in Unit B were probably deposited in well drained swamps that occur along the margins of channel sandstones because most of the organic material would have oxidized when drained by the fluvial system. 


\section{$\mathrm{CH}-132$ \\ $134.2-134.4$}

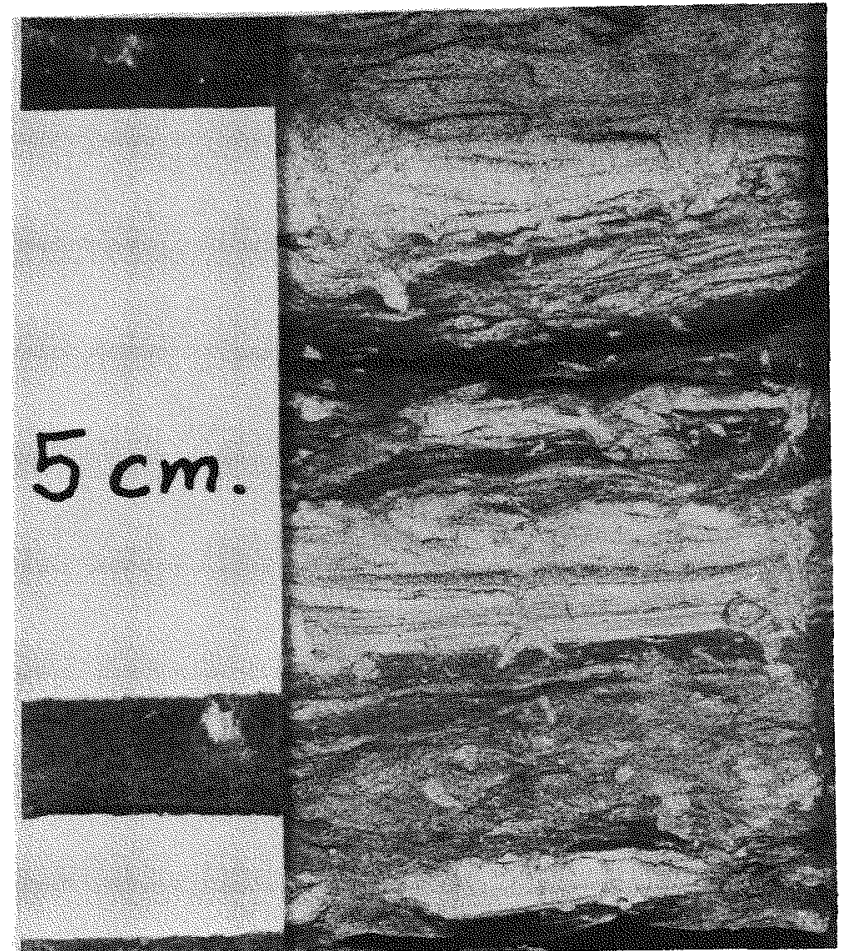

a

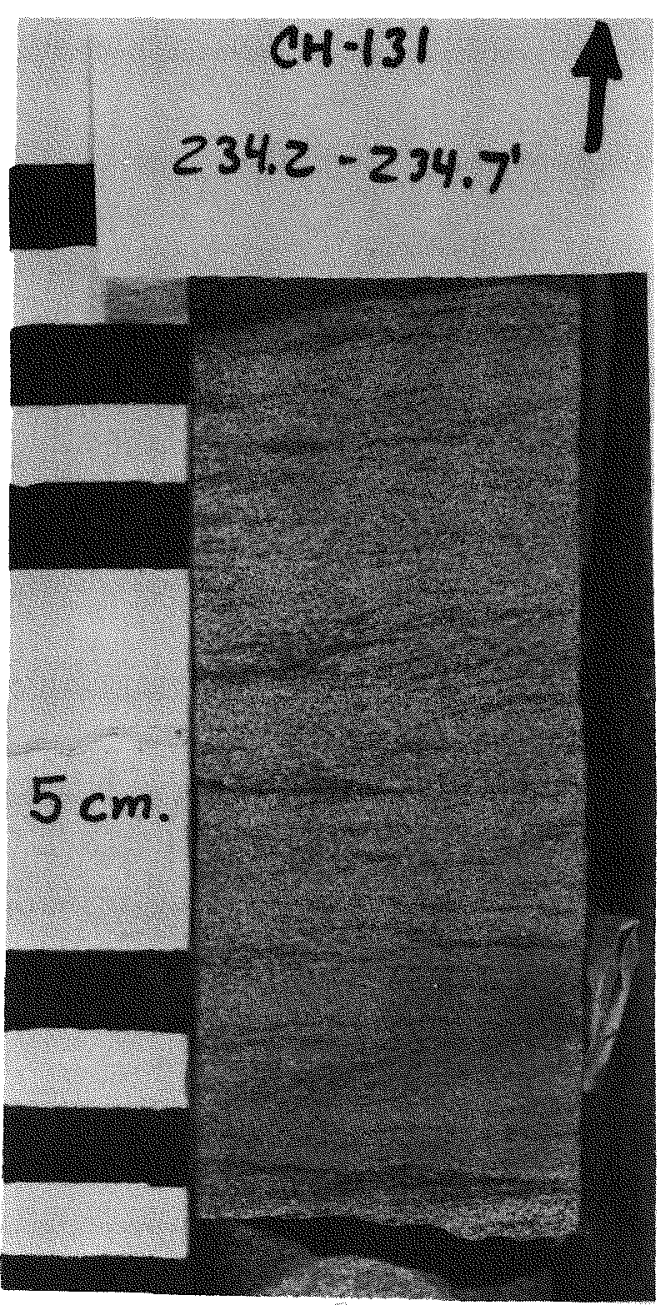

b

Figure 17. Core photographs from Unit B: a) interbedded arid burrowed mudstones and fine-grained sandstones; b) ripple cross-stratified fine-grained sandstone. 
The claystones identical to those found in Unit $A$ are interpreted as deposits in small lakes associated with the meandering river system.

The lenticular sandstone bodies were probably deposited as point bars in the meandering river system. The point bar deposits are characterized by a vertical sequence of features produced by lateral migration of the bar. First, a basal erosional contact overlain by clay clast lag and fine-grained trough cross-bedded sandstones represents deposition in a lower point bar. Second, the lower point bar grades into very finegrained planar and ripple cross-stratified sandstones representing the upper point bar deposits. Third, the point bars are overlain by rooted siltstones and mudstones of the levee or abandoned channel fill.

The thin, tabular, very fine-grained sandstones (less than $5 \mathrm{ft}$ ) were deposited by crevasse splays that were formed during times of flooding when levees were breached, allowing sediment laden water to invade the floodplain. The combination of rapid sedimentation and slow water currents resulted in the deposition of climbing ripples (Craig et a]., 1982).

Unit $\mathrm{C}$

This unit truncates Unit B and consists of coarse-grained to finegrained sandstones with conglomeratic beds. Some minor amounts of shale are found within the unit. There are numerous thin (6 to 12 in) finingupward sandstone sequences bounded by erosional contacts. The predominant sedimentary structures are high-angle (up to 25 degrees) planar cross-stratification and rough cross-stratification (Figure 18). The conglomerate beds are composed of quartzite pebbles, clay clasts, and carbonized material in a sandstone matrix.

The medium to coarse-grained sandstones and conglomerates of Unit $c$ were deposited in a braided river system. Four distinguishing features found in the cores indicate a braided river environment: (1) few stratification types, (2) rare ripple cross-lamination, (3) high sand and gravel content, and (4) multilateral sand body geometry indicated by numerous thin fining-upward cycles. There is evidence from core studies to indicate the presence of transverse bars (thick, fine to medium grained sandstone sequences with high-angle planar stratification), longitudinal bars (clast supported conglomerates with crude horizontal bedding), and interbar channels (fining-upward trough cross-bedded sandstones containing erosional basal contacts with clay clast lags) (Craig et a1., 1982).

Unit D

The upper unit (D) contains characteristics similar to both unit $A$ and unit $B$ described above. Portions of this unit are characterized by mudstones and lenticular, cross-stratified sandstones. Other parts of the unit consist of fine-grained sandstones to siltstones with highangle foresets, contorted beds, ripple cross-stratification, and bioturbation (Figure 19). Finally, thin coal beds are also present. This unit exhibits a sharp lower contact where observed in two continuous cores (Craig et a1., 1982). 

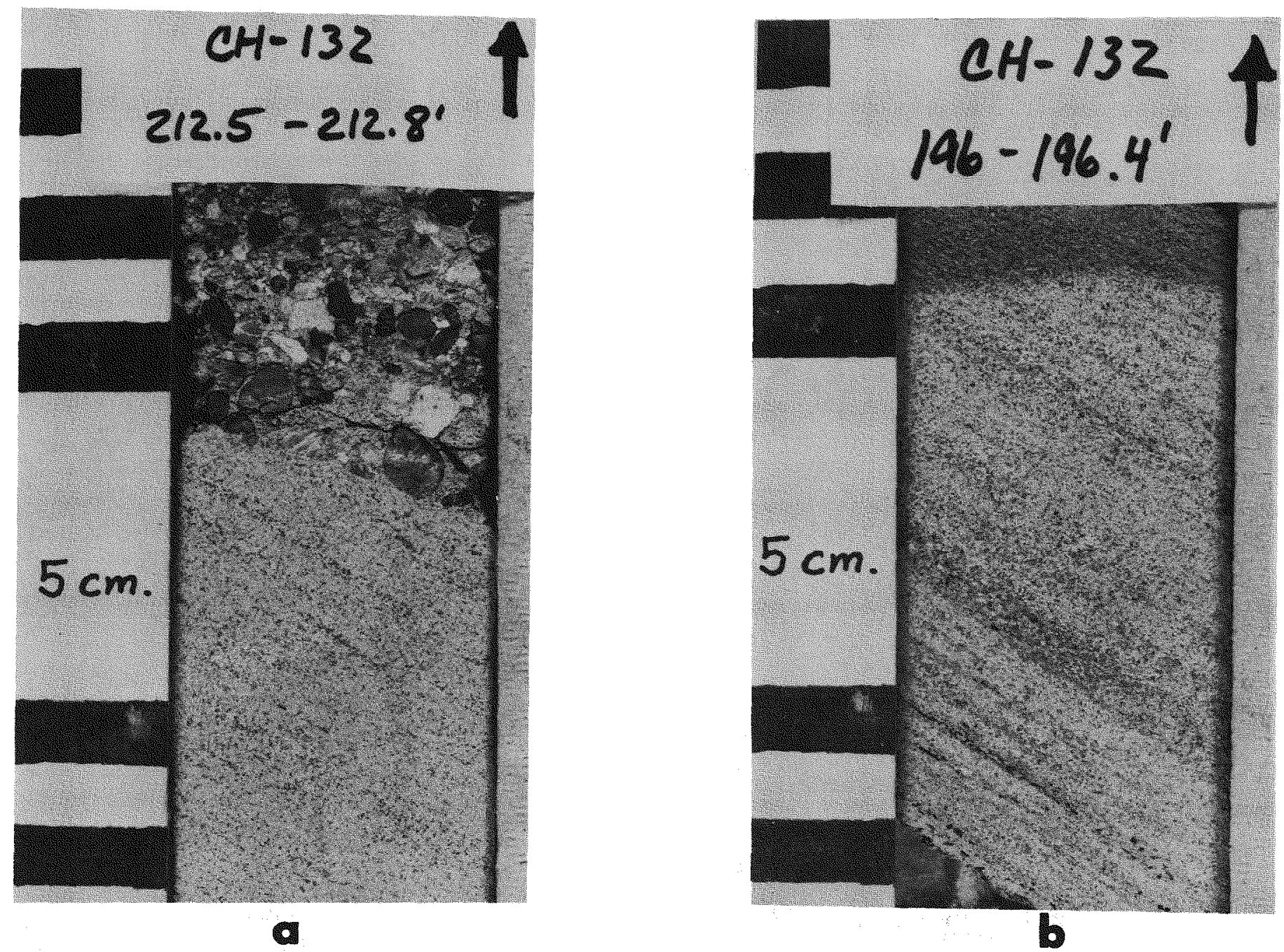

Figure 18. Core photographs from Unit C: a) erosional contact between beds; b) planar crossstratification. 

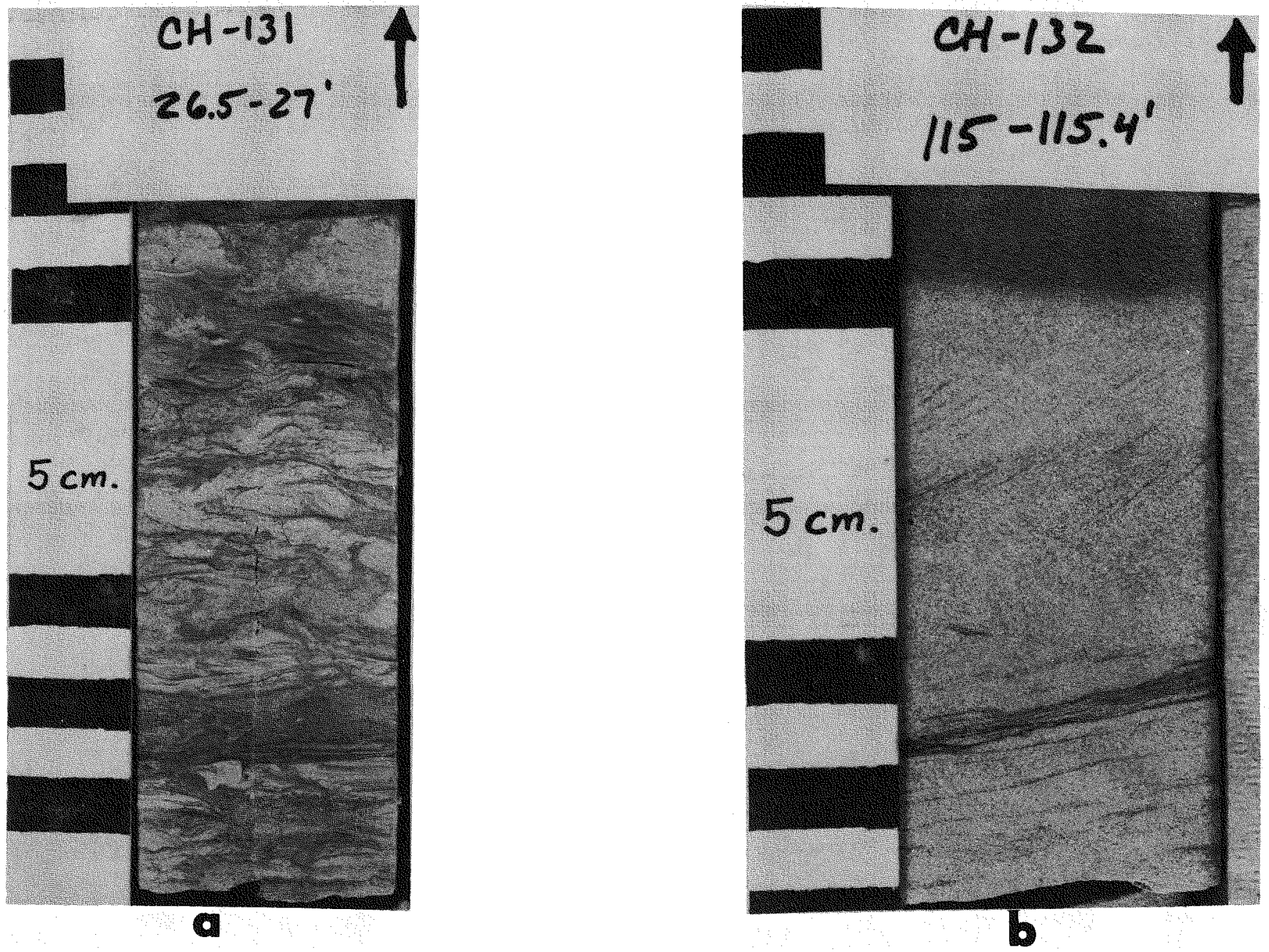

Figure 19. Core photographs from Unit D: a) interbedded silt and sand with contorted bedding; b) medium-grained cross-stratified sandstone. 
Sandstones and mudstones of unit $D$ were deposited in meandering rivers, crevasse splays, and floodplains (Figure 20) similar to those that existed during the deposition of unit $B$ and in lakes and lacustrine deltas similar to those that existed during accumulation of unit $A$.

Coal beds such as the Hanna No. 1 coal and also the thinner coals found in unit $D$ represent accumulation of organic matter that were deposited in poorly drained swamps that covered an area much larger than the present-day extent of the study site (Craig et al., 1982).

Conclusions

Interpretations of the environments of deposition for each of the units described above are given and illustrated in Figure 20. Hanna Formation strata at the Hanna UCG sites were deposited in braided stream, meandering stream channel, fluvial floodplain, crevasse splay, and lacustrine delta depositional settings.

Stratigraphic relations of the several local stratigraphic units are depicted by four cross sections after Craig et al. (1982) (Figures 21 through 24). The location of each cross section is shown by a solid line in an insert map above the section. The location of all other cross sections is shown by dashed lines. All of the cross sections are stratigraphic sections using the top of the Hanna No. 1 coal as a horizontal datum. With this type of section, present-day structural relations and features are eliminated and stratigraphic relations are enhanced.

Significant vertical and lateral relations among the various rock units are illustrated in the cross-sections. These relations include:

1) The lateral interfingering of lacustrine delta deposits and lacustrine deposits in unit A (Figure 22).

2) The lenticular nature of channet deposits (CH) in unit $B$ (Figures 22 and 23).

3) The relatively thin, tabular nature of crevasse splay deposits (CR) in unit B (Figures 21 and 23).

4) The lenticular nature of lake deposit ( $L$ ) in unit $B$ (Figures 22 and 23). These thin discontinuous lacustrine sequences may represent deposits of abandoned channels (oxbow lakes).

5) The erosional nature of the base of the braided stream deposits (unit $C$ ) which truncate several different underlying rock types (Figure 21).

6) The tabular uniform nature of the Hanna No. 1 coal bed below unit $A$ (Figures 21 and 23 ).

7) The thin, lenticular nature of coal beds in unit $B$ (Figure 21). 


\section{UNIT B}

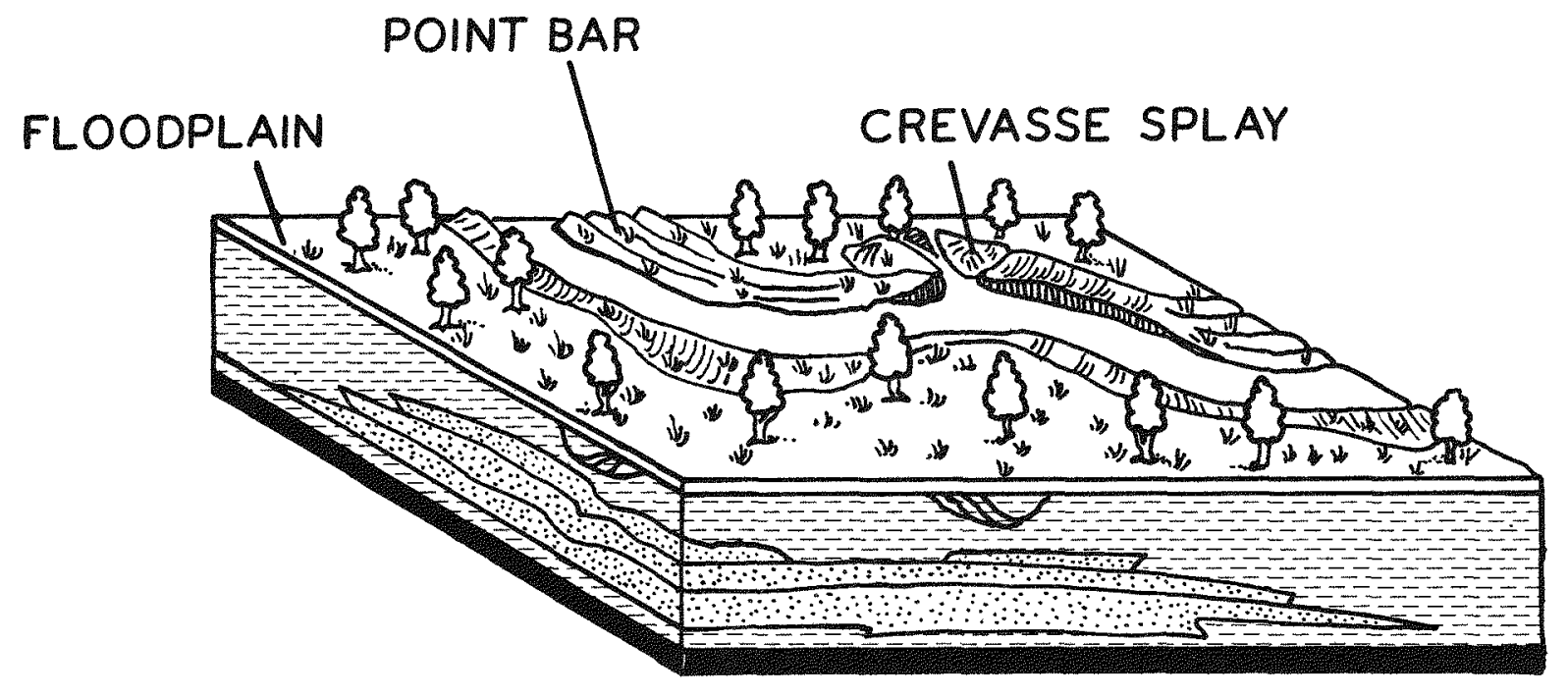

\section{UNIT A}

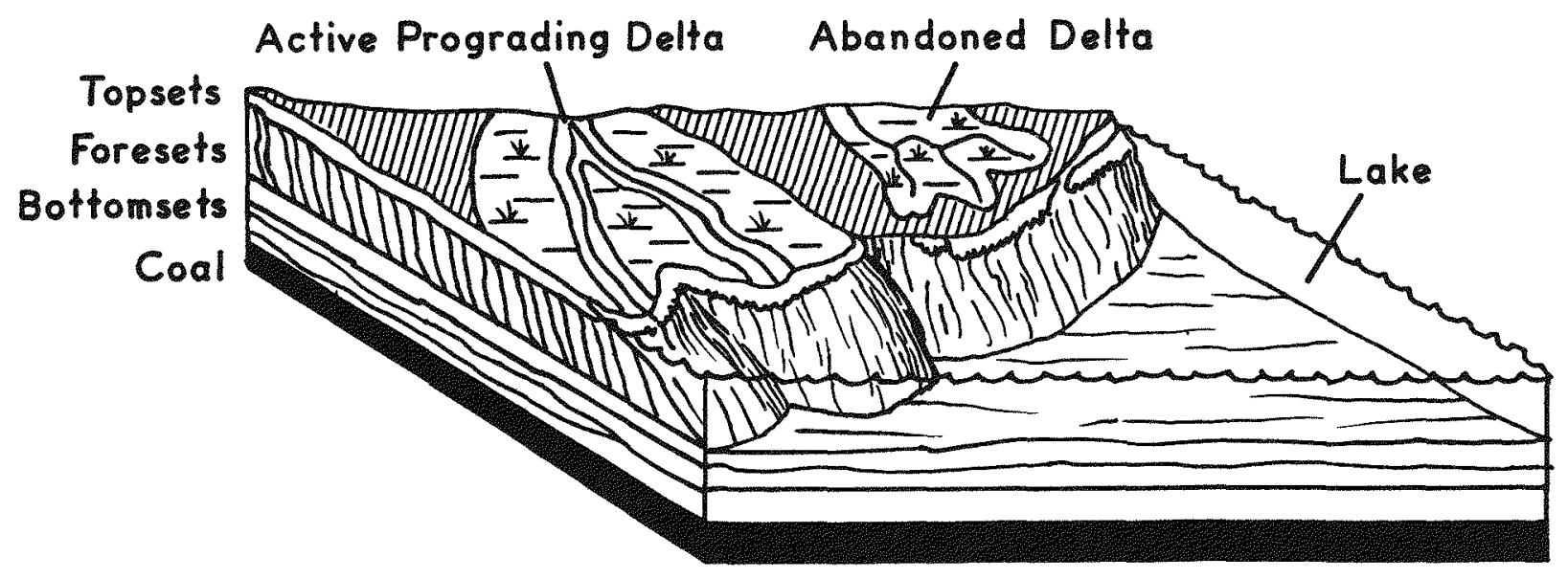

Figure 20. Schematic reconstruction of inferred depositional settings of the overburden units, Hanna UCG site (after Youngberg et al., 1983 and Craig et al, 1982). 


\section{UNIT D}

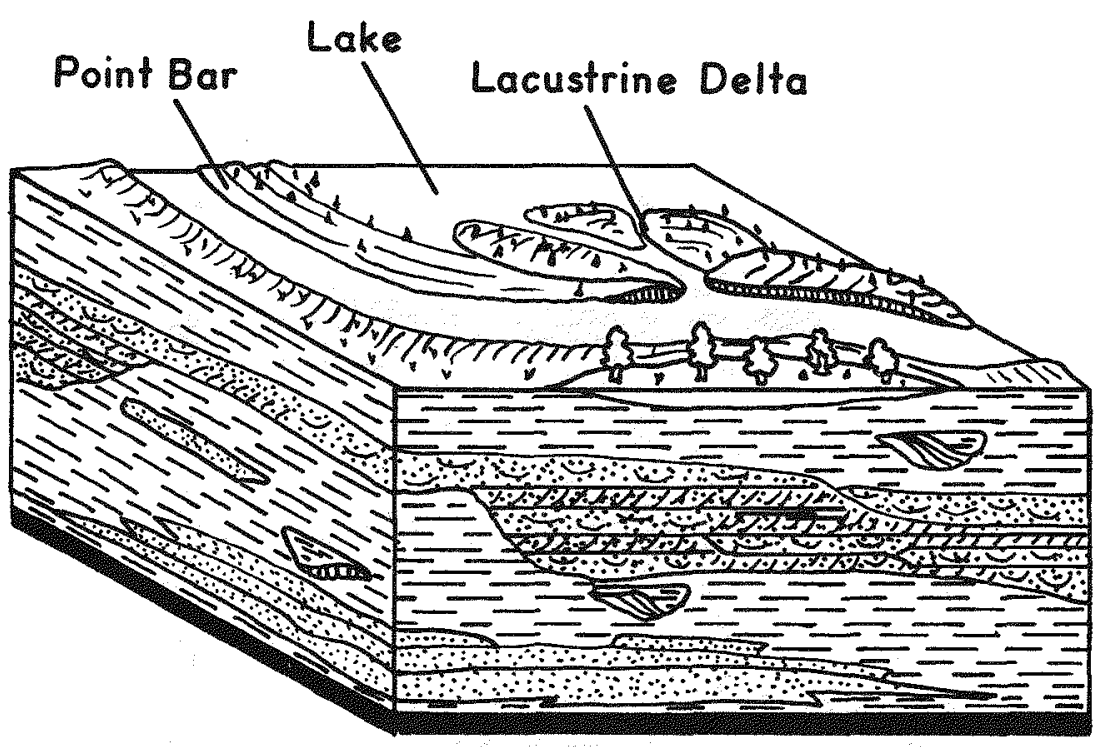

\section{UNIT C}

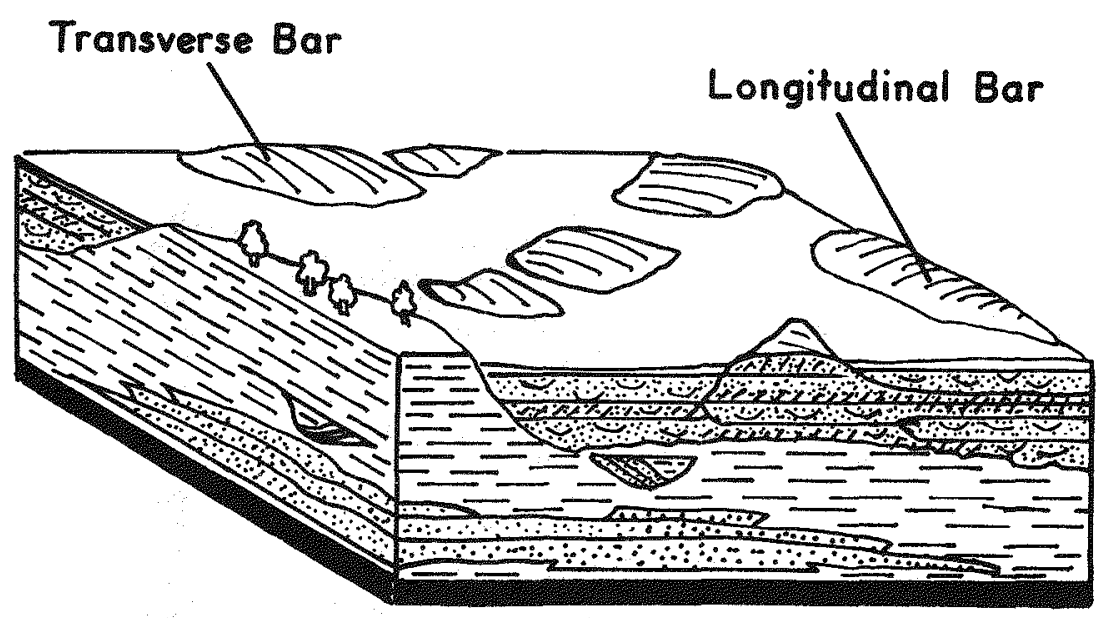

Figure 20 (Continued). 


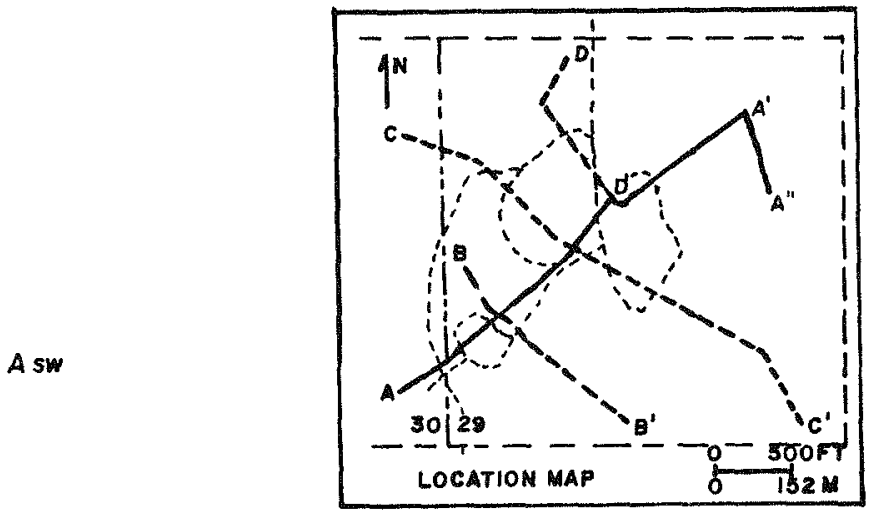

\section{WIII OREPIDED RIVER PDS POORLY DRAINED SWAMP \\ CH MEANDERING \\ CA CREvasse splat}

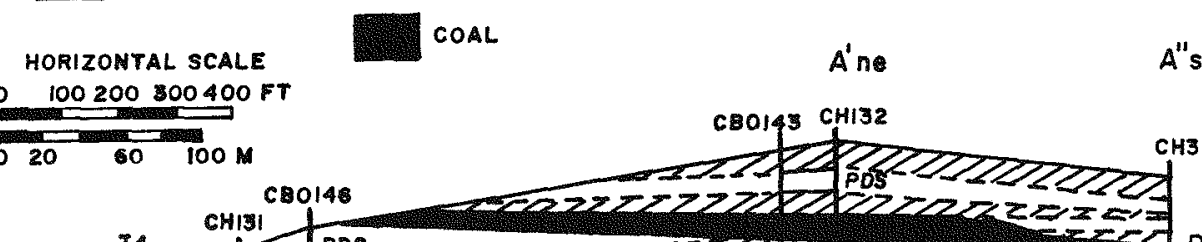

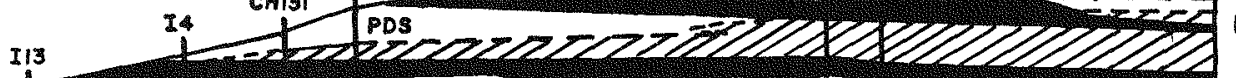

$\stackrel{\infty}{\infty}$

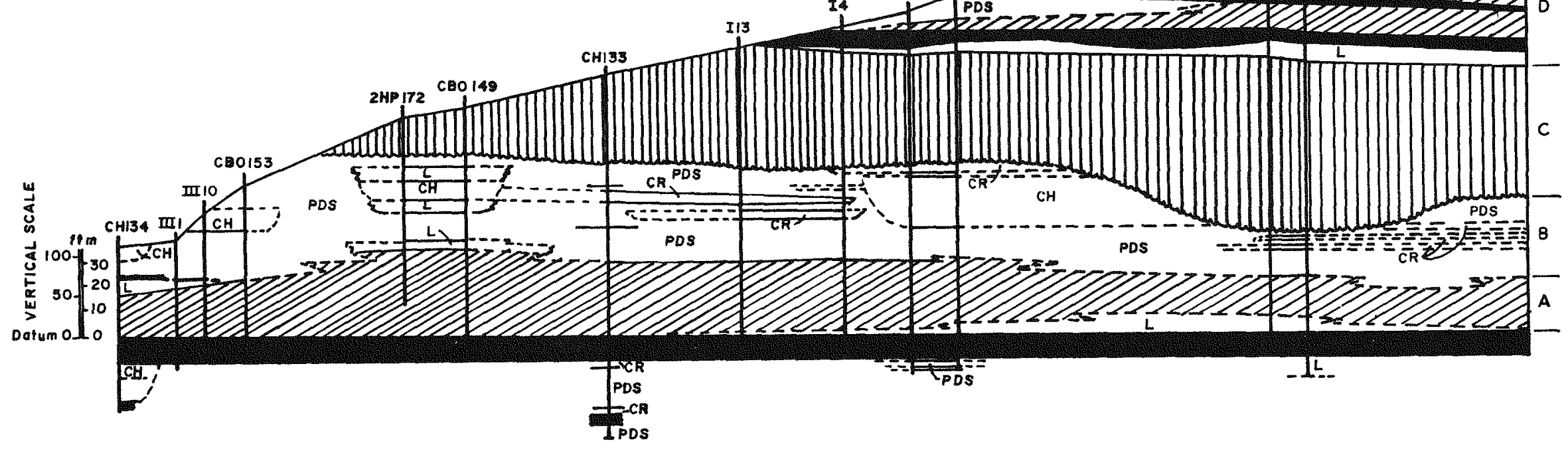

Figure 21. Northeast to southwest stratigraphic cross section A-A' (after Craig et al., 1982). 

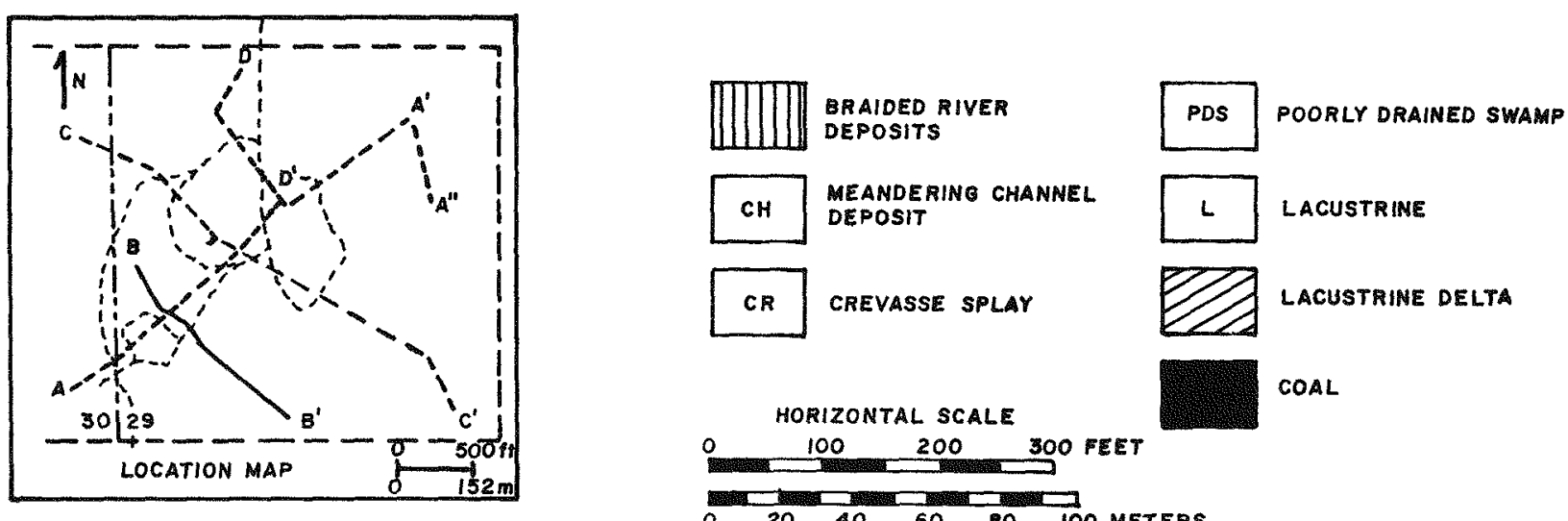

CH MEANDERING CHANNEL
DEPOSIT
CR CREVASSE SPLAY LACUSTRINE

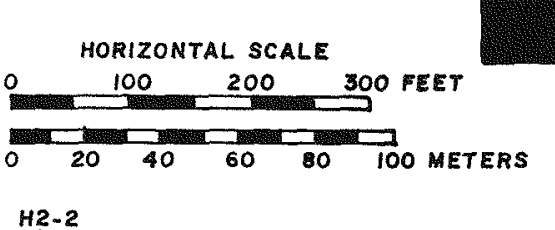

COAL

OVB 140

H2-2

$B^{\prime} S E$

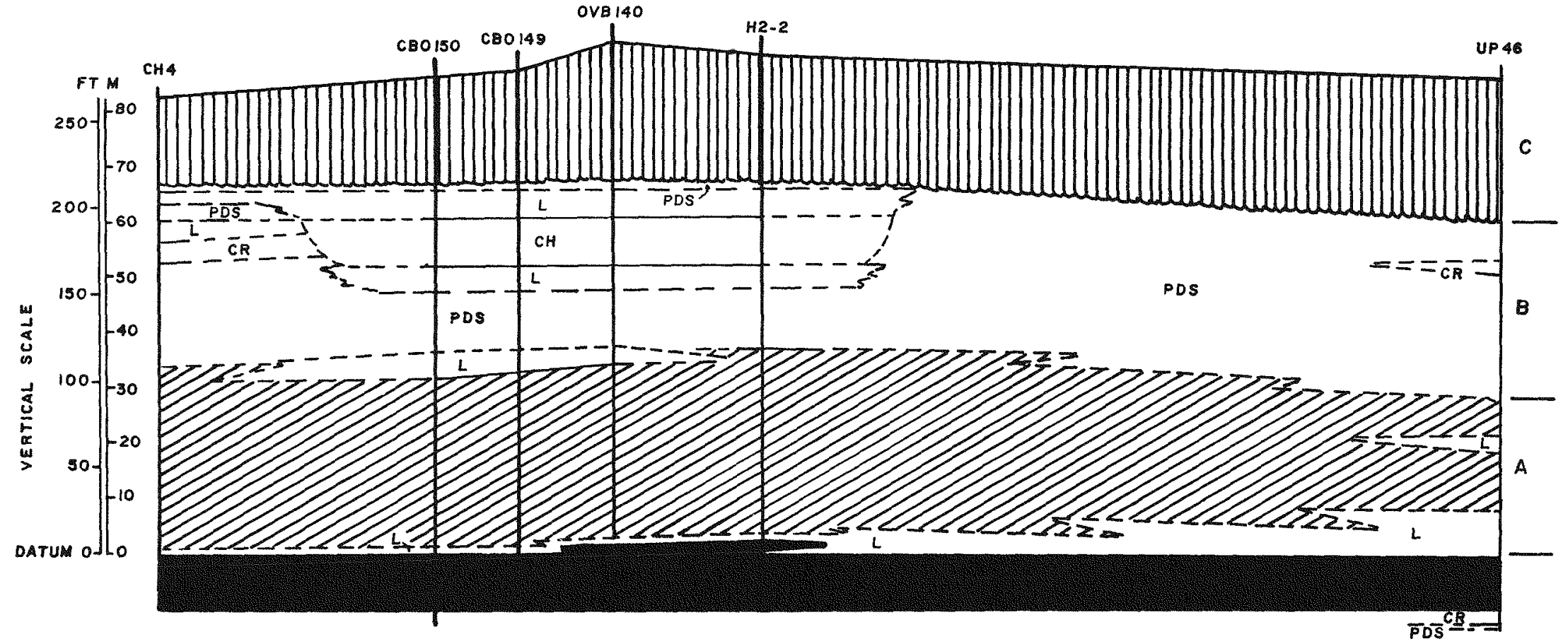

Figure 22. Northwest to southeast stratigraphic cross section B-B' (after Craig et a1., 1982). 

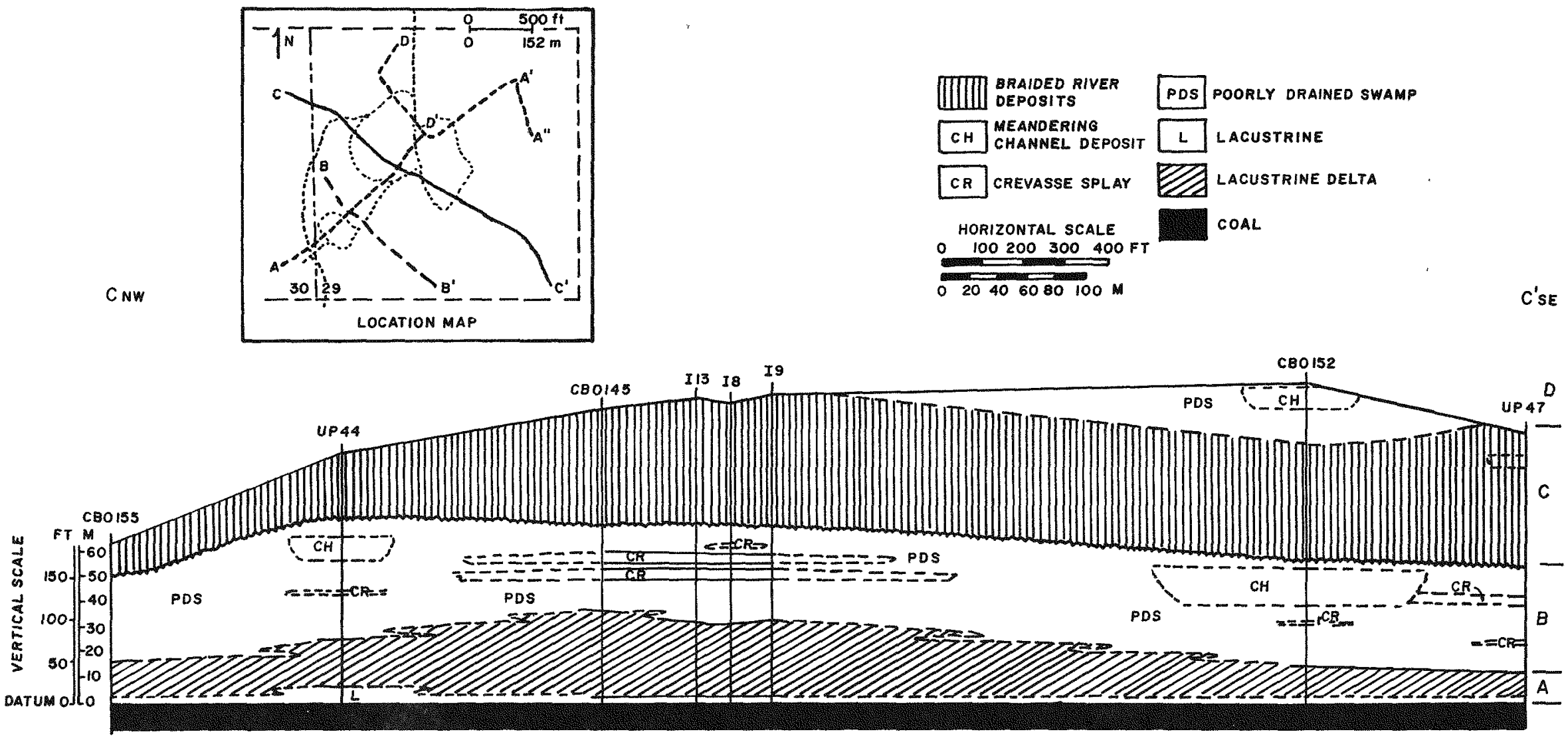

Figure 23. Northwest to southeast stratigraphic cross section C-C' (after Craig et a1., 1982). 


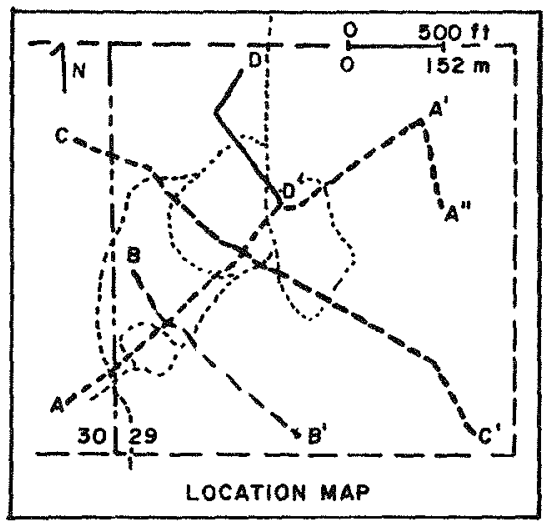

$$
\text { IIII] } \begin{aligned}
& \text { BRAIDED RIVER } \\
& \text { DEPOSITS }
\end{aligned}
$$

CH MEANDERING CHANNEL L L LAGUSTRINE

CR CREVASSE splay
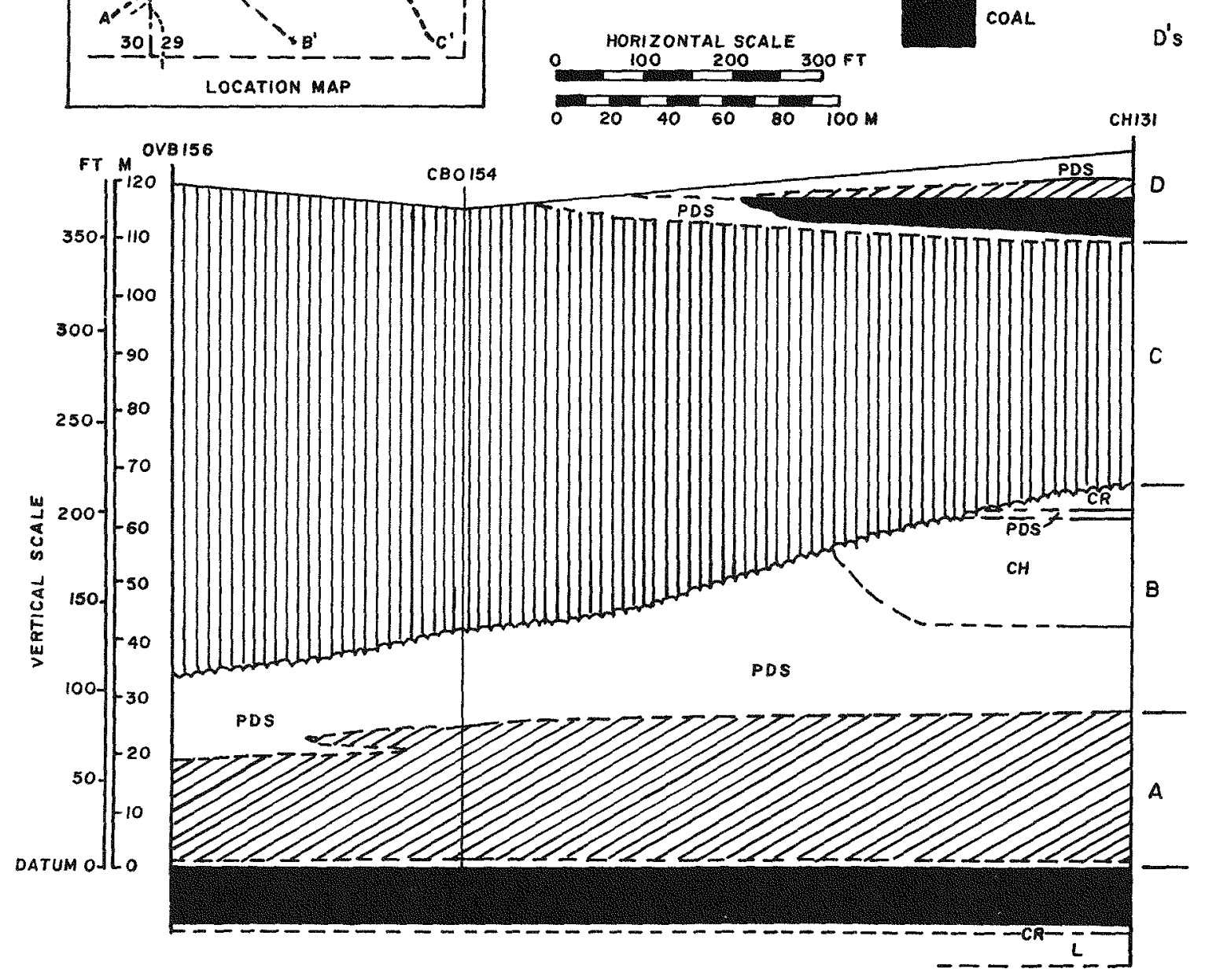

Figure 24. Northwest to southeast stratigraphic cross section D-D' (after Craig et al., 1982). 


\section{Stratigrahic Unit Geometry}

The Hanna No. 1 coal bed is relatively uniform in thickness throughout the study area as shown by the structural cross section (Figure 10). In eight continuous cores that penetrated the entire bed, the thickness ranged from $37 \mathrm{ft}$ to $27 \mathrm{ft}$. Over 40 geophysical logs indicate a range of $23 \mathrm{ft}$ to $32 \mathrm{ft}$. An isopach map of the Hanna No. 1 coal bed is shown in Figure 7 and Plate I.

The thickness of unit A directly above the Hanna No. 1 coal bed ranges from $115 \mathrm{ft}$ to $35 \mathrm{ft}$. The unit forms a fan-shaped deposit which originates west of the west-central portion of the study area and fans out in an easterly to northeasterly direction (Plate II). The maximum dimensions of this unit are $2800 \mathrm{ft}$ in a southwest to northeast direction and $2500 \mathrm{ft}$ in a north to south direction. This is an excellent grahic representation of the lacustrine delta depositional environment of unit $A$.

The thickness of unit $B$ ranges from $137 \mathrm{ft}$ in the west-central portion of the study area to zero where it is truncated by erosion southwest of the study area (Plate III). The unit consists of a northwest to southeast oriented belt which thins to the northeast and southwest away from an axis of maximum thickness. The isopach map reveals a minor, secondary thickening orientation at right angles to the major trend in the southwest and central portions of the study area. This is a feasible geometry for the proposed meandering river channel-floodplain depositional environment of Unit $B$ with the channel represented by the trends of the thicks and the floodplain represented by the thins on the flanks.

The thickness of unit $C$ ranges from $274 \mathrm{ft}$ near the northeast portion of the study area to zero where it is truncated by erosion southwest of the Hanna II burn cavity (Plate IV). This unit consists of a wedge shaped deposit that strikes northwest to southeast and thins to the southwest. This geometry is appropriate for the proposed braided stream depositional environment.

A11 of unit $D$ is not present at the UCG site area, thus the development of an accurate isopach map is impossible. However, the unit attains a thickness of $154 \mathrm{ft}$ in corehole $\mathrm{CH}-132$ and is eroded completely away in the southwest corner of section 29 (Plate $V$ ). The geometry shown by the isopach in Plate $V$ is strictly representative of the erosional pattern.

An isopach of the total overburden at the Hanna UCG site is shown in Plate IV. The overburden gets progressively thicker to the northeast which is the direction of bed dip in the area. 


\title{
MINERALOGY AND PETROLOGY
}

\author{
Overburden
}

\section{Composition}

Unit $A$ of the overburden lies directly above the Hanna No. 1 coal bed and is, therefore, the main overburden unit controlling spalling and cavity development. Its thickness and lateral continuity are sufficient to retain all spalling within itself. These characteristics listed above support a study of the unit's mineralogy. The five basic rock types found in overburden Unit A at the Hanna UCG study site are: 1) calcareous sandstone, 2) calcareous siltstone, 3) calcareous shale, 4) ironstone, and 5) carbonaceous shale (Colorado School of Mines, 1979). These rock types and their relative abundance in Unit A are shown in Figure 25. As shown in the diagram, the calcareous sandstone 1ithologic type is by far the most common, making up 72.2 percent of the total overburden based on 106.9 feet of core. The other four rock types make up on ty minor portions of the overburden.

The bulk mineralogy of overburden Unit $A$ at the Hanna UCG site is shown in Figure 26 (Colorado School of Mines, 1979). As expected, due to the dominance of the calcareous sandstone lithofacies, the mineral quartz is by far the most common mineral in the unit. Quartz comprises 53.1 percent making it more common than the other nine mineral constituents combined. The calcareous nature of the overburden rock is shown by adding the amounts of calcite, dolomite, and siderite present. This combination shows that 18 percent of the overburden is made up of calcareous minerals.

The bulk mineralogies of the five basic rock types are shown in Figures 27 through 31. With the exception of the ironstone 1ithofacies, quartz retains its dominance of mineral types. In the ironstone 7 ithofacies (Figure 30), siderite makes up over 80 percent of the rock. The calcareous or carbonate nature of four of the five 7 ithofacies is shown by adding calcite, dolomite and siderite for each rock type, giving results as follows: 1) calcareous sandstone - 15.7 percent; 2) calcareous siltstone - 15.4 percent; 3) calcareous shale - 14.4 percent; and 4) ironstone -81.3 percent.

Kaolinite, smectite, and illite are the clay mineral groups that were identified in overburden core samples. Kaolinite is the most abundant clay, followed by smectite and illite. Kaolinite forms from weathering under conditions of well drained acidic soils in temperate climates. Illite forms where potassium ions are abundant (Krauskopf, 1979). It appears that a large percentage of the clay minerals present at the Hanna UCG area were transported into the site of deposition. Some crystallization of new clay minerals was detected (Craig, 1982).

Sandstones from the three overburden units $A, B$ and $C$ have distinct compositional characteristics as summarized in Table 2. Lacustrine delta sandstones from Unit A are composed predominantly of quartz $(80.8$ percent) and Tithic ( 3.7 percent) fragments. The point bar sandstones 


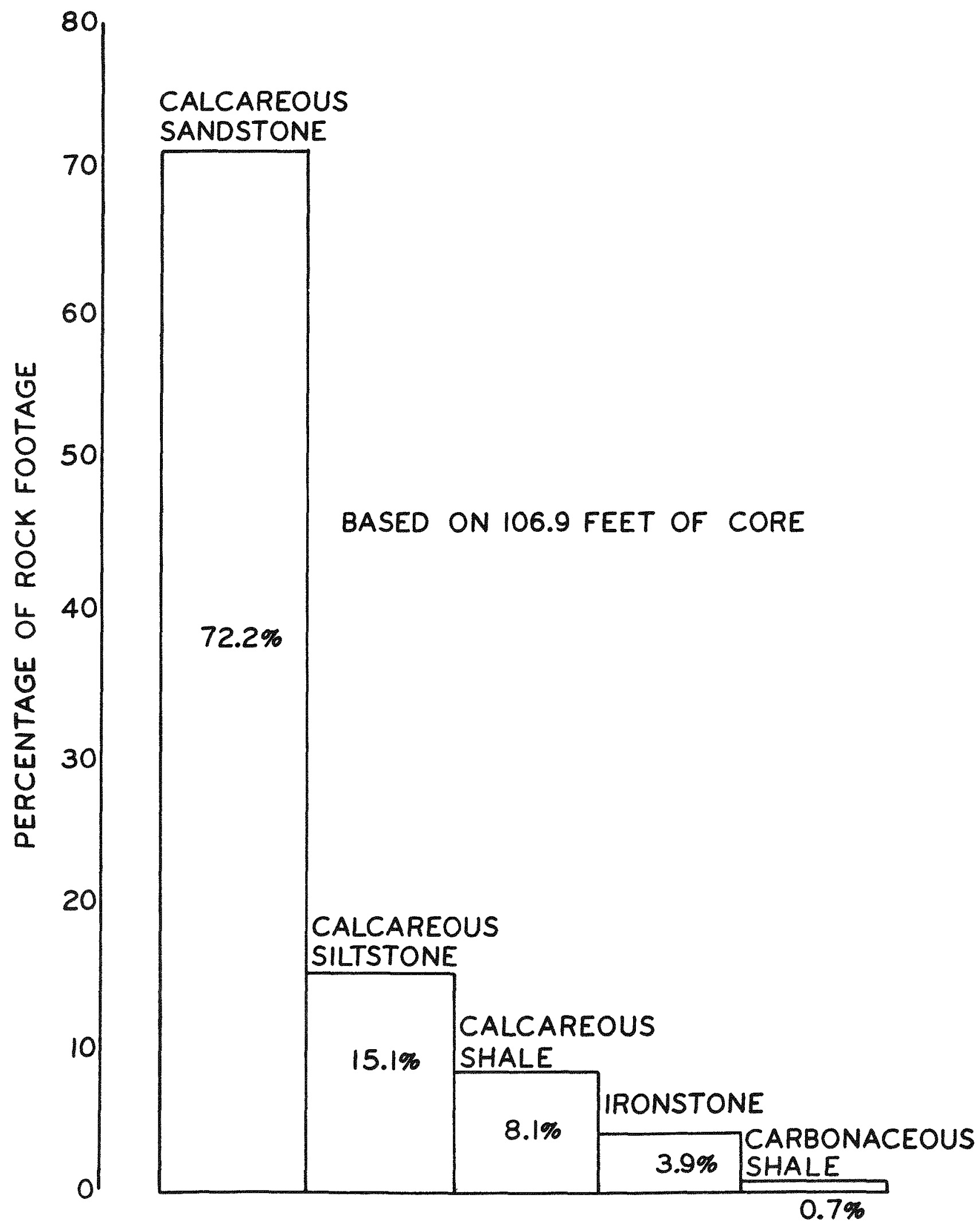

Figure 25. Overburden rock types in Unit A at the Hanna UCG study site. 


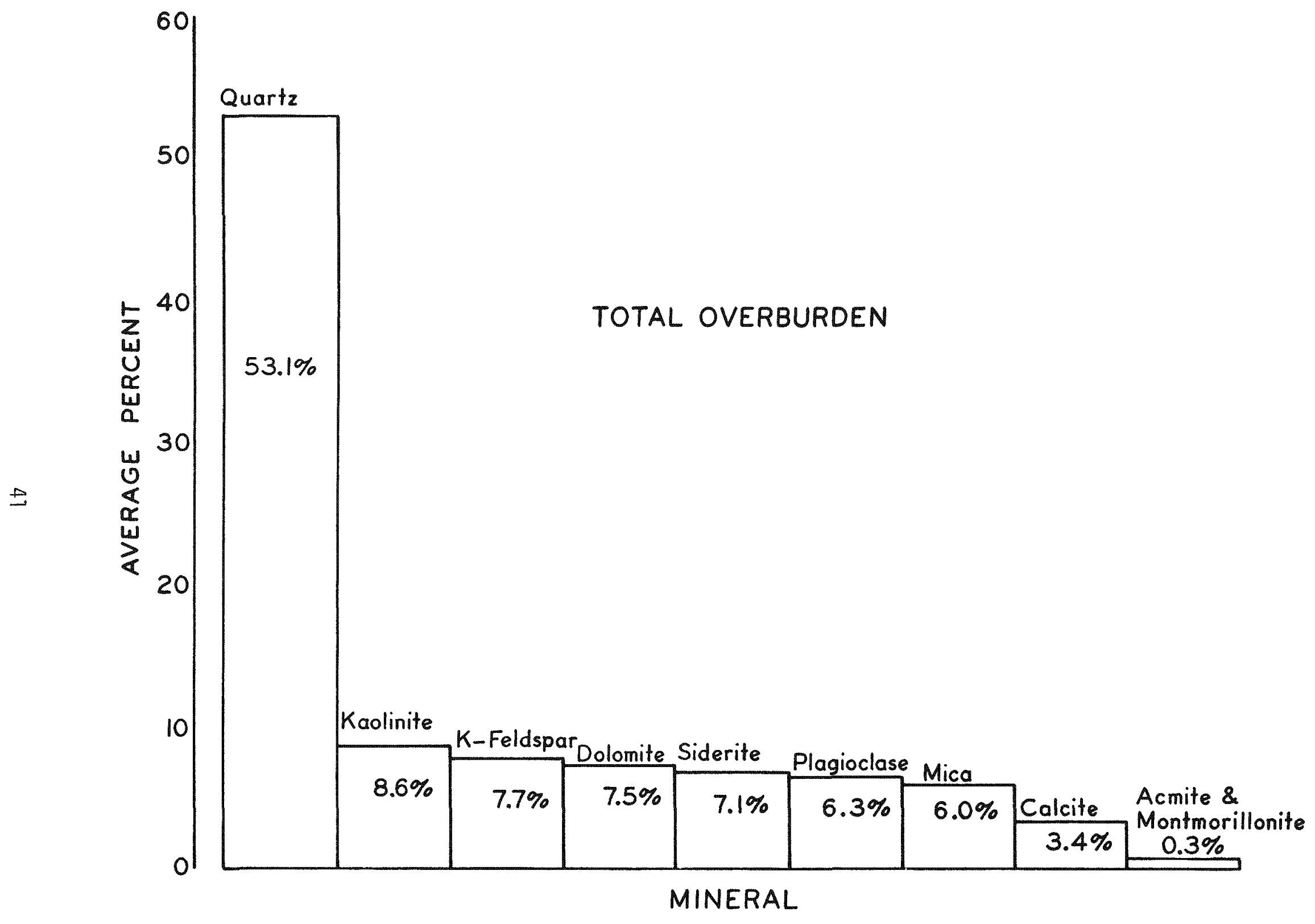

Figure 26. Overburden bulk mineralogy in Unit $A$ at the Hanna UCG study site. 


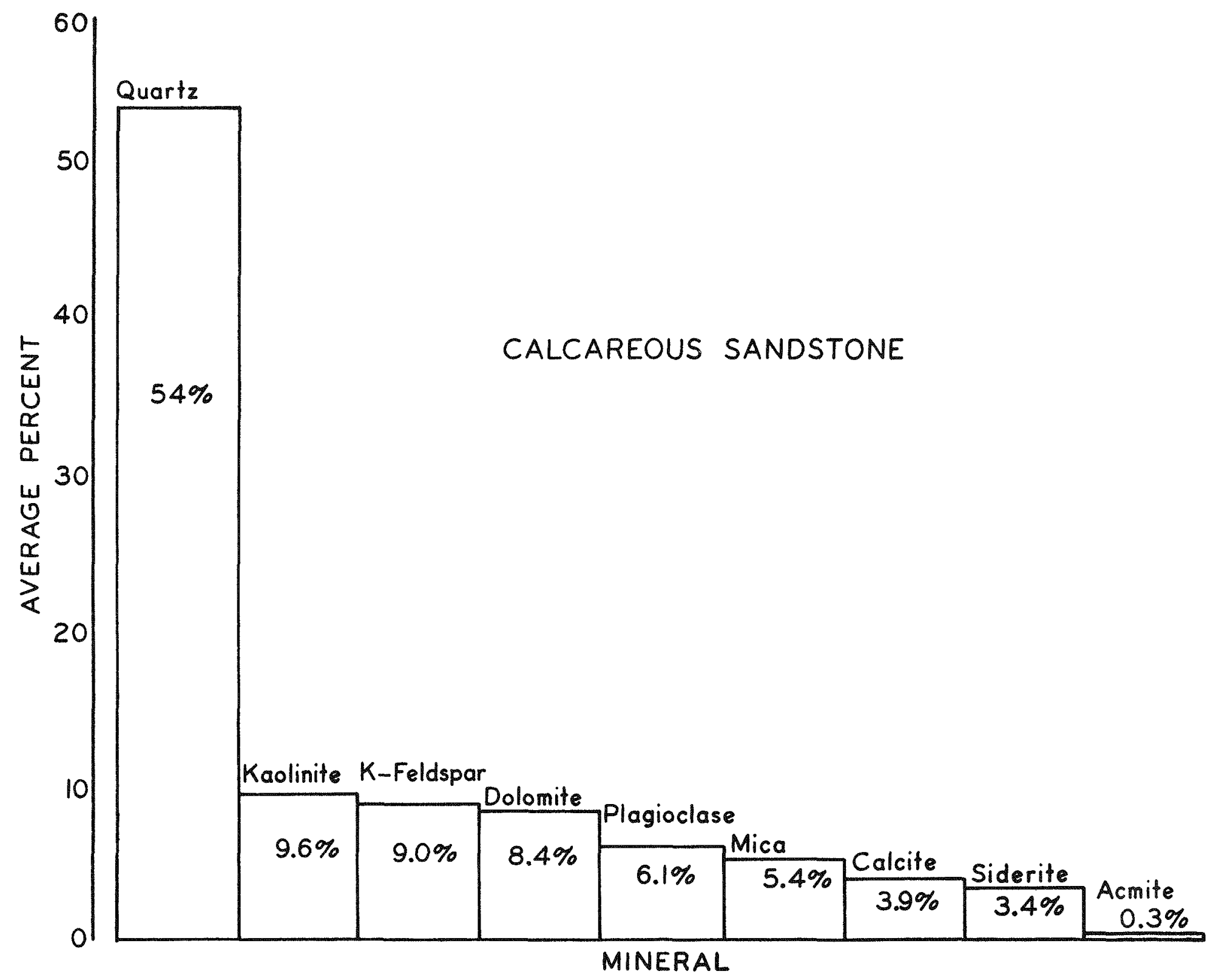

Figure 27. Bulk mineralogy of the calcareous sandstone rock type from Unit $A$, Hanna UCG site. 


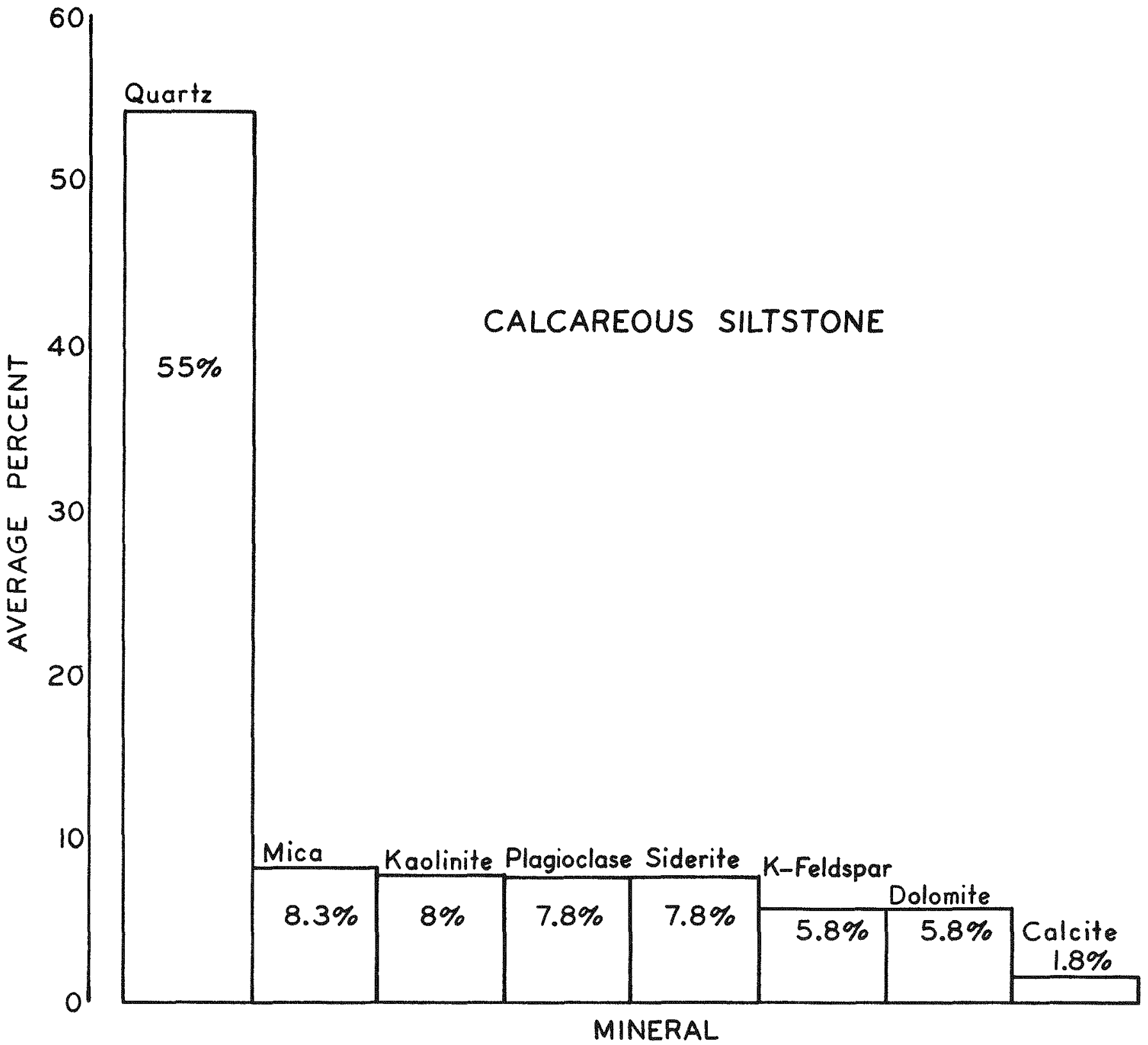

Figure 28. Bulk mineralogy of the calcareous siltstone rock type from Unit A, Hanna UCG site. 


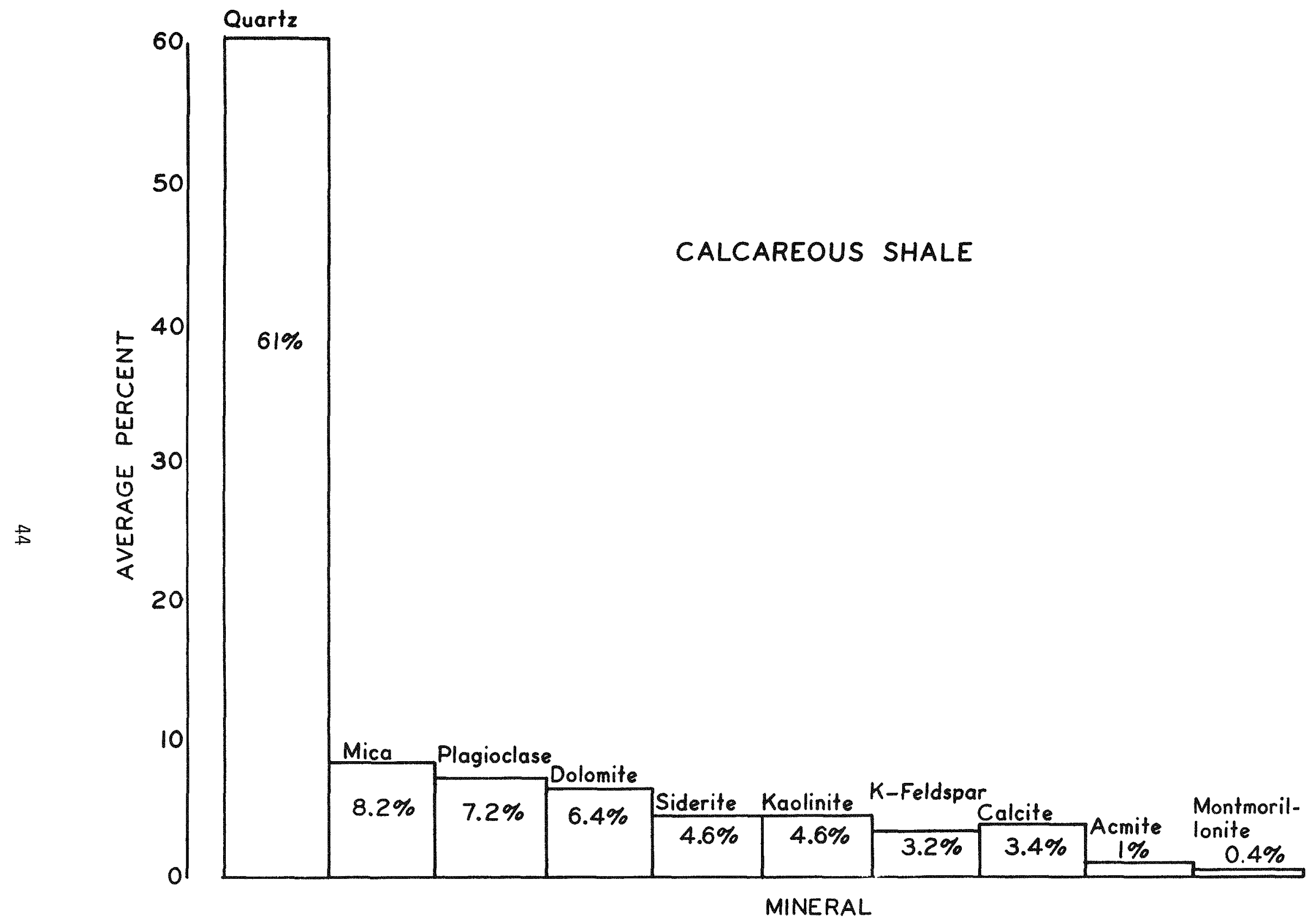

Figure 29. Bulk mineralogy of the calcareous shale rock type from Unit $A$, Hanna UCG site. 


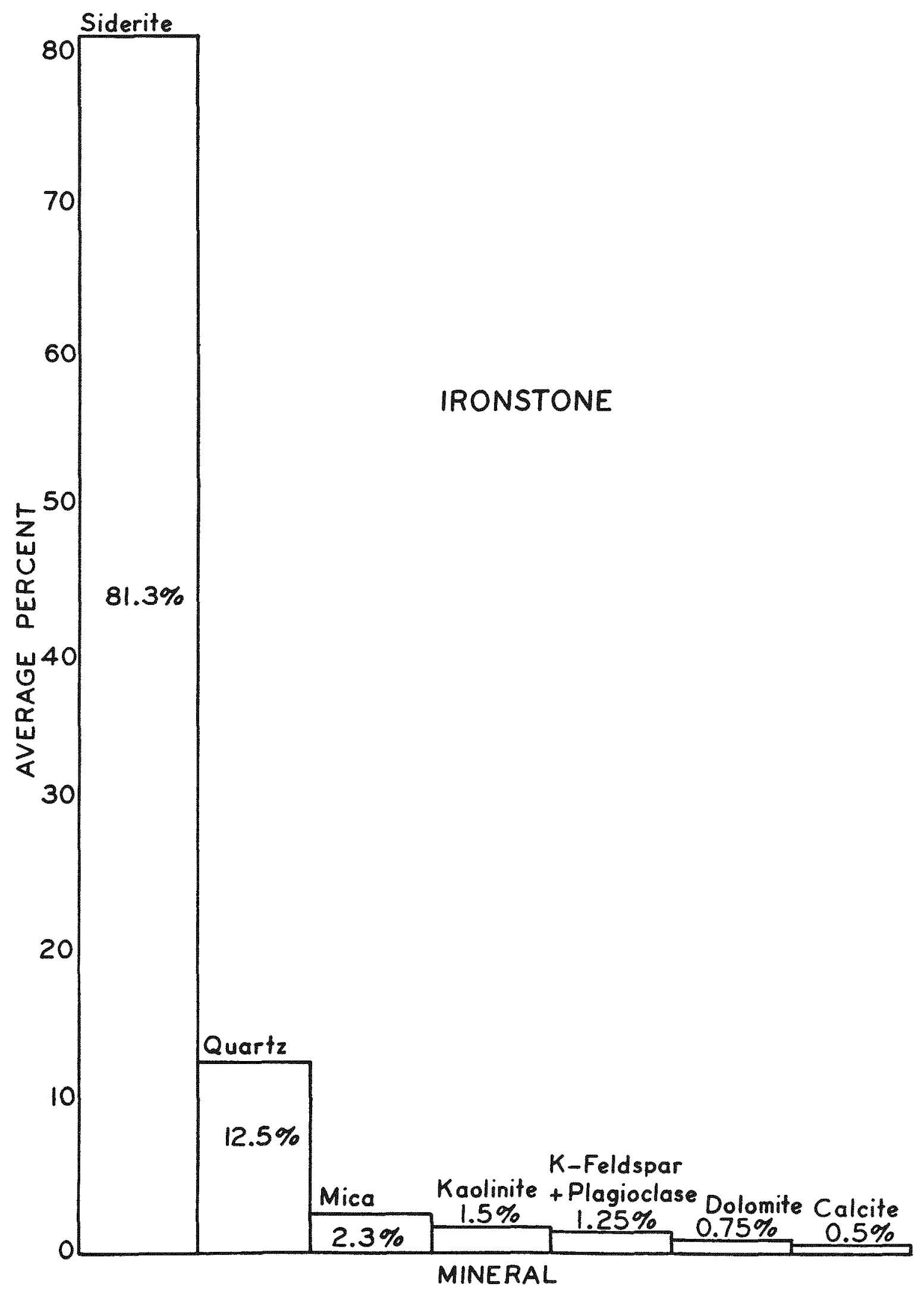

Figure 30. BuTk mineralogy of the ironstone rock type from Unit A, Hanna UCG site. 


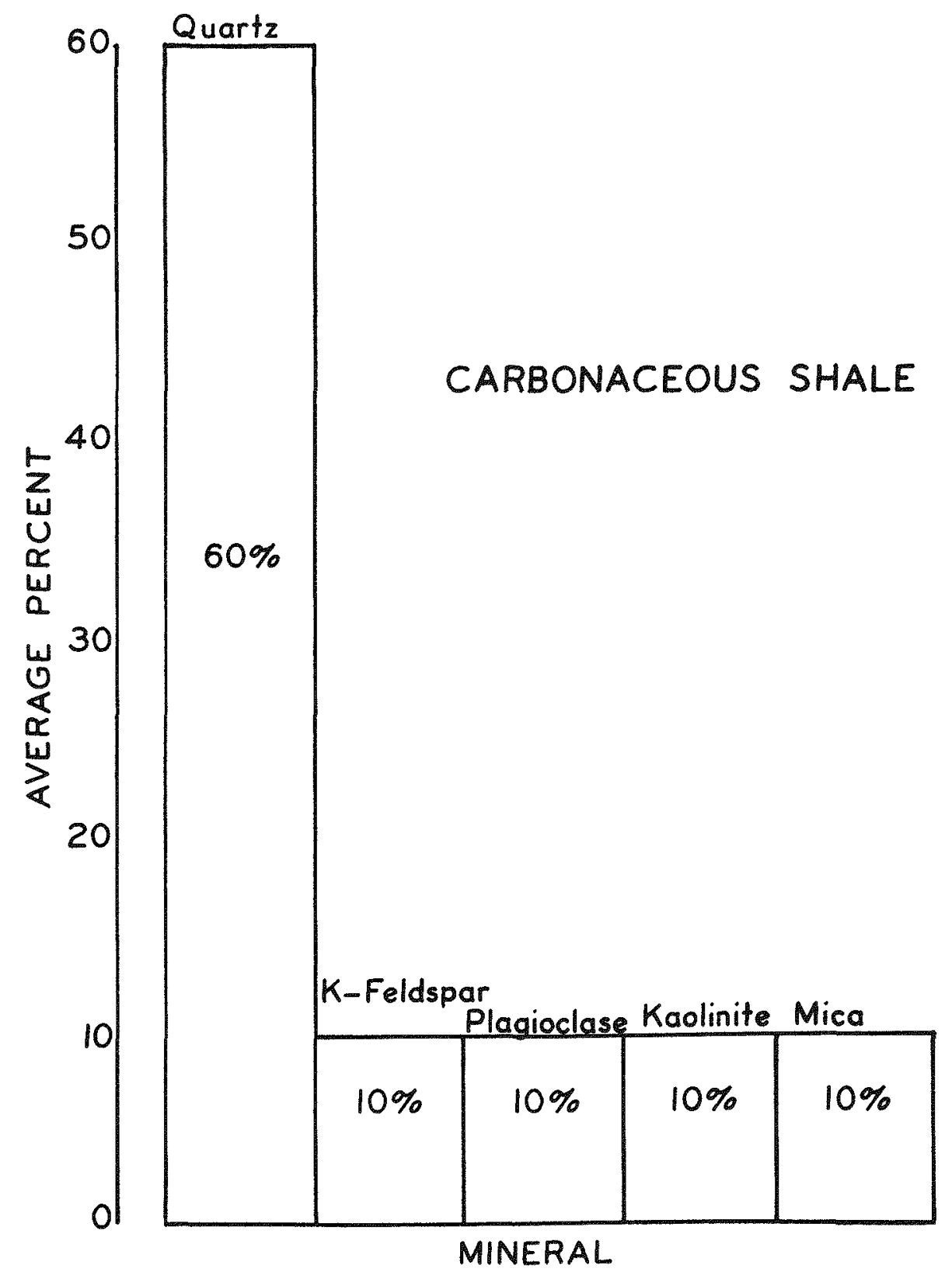

Figure 31. Bulk mineralogy of the carbonaceous shale rock type from Unit A, Hanna UCG site. 
Table 2. Average composition of fifty-nine sandstone samples from the Hanna Formation, Hanna, Wyoming (after Craig, 1982).

\begin{tabular}{|c|c|c|c|c|c|c|c|c|c|c|c|c|c|c|}
\hline & $Q p$ & Qm & $Q t$ & $K$ & $P$ & $\begin{array}{l}\% \text { DET } \\
\text { Frx }\end{array}$ & $\begin{array}{r}\text { RITAL } \\
\mathrm{Ft} \\
\end{array}$ & $\begin{array}{l}\text { RACTI } \\
\text { LV }\end{array}$ & $\mathrm{Lm}$ & LS & $\mathrm{Lt}$ & A & M & $\mathrm{Ma}$ \\
\hline $\begin{array}{l}\text { LACUSTRINE } \\
\text { DELTA (A) }\end{array}$ & 0.2 & 63.6 & 80.8 & 2.0 & 0.4 & 0.1 & 2.4 & 0.3 & 0.2 & 3.1 & 3.7 & 7.8 & 4.5 & 5.0 \\
\hline $\begin{array}{l}\text { POINT BARS } \\
\text { (B) }\end{array}$ & 23.2 & 48.3 & 71.4 & 7.4 & 1.2 & 3.0 & 11.6 & 1.4 & 0.5 & 10.1 & 12.0 & 1.8 & 3.5 & 2.3 \\
\hline $\begin{array}{l}\text { BRAIDED } \\
\text { RIVER (C) }\end{array}$ & 23.1 & 39.0 & 62.1 & 8.9 & 0.0 & 3.7 & 12.6 & 5.2 & 2.9 & 11.9 & 19.0 & 1.5 & 2.9 & 0.0 \\
\hline
\end{tabular}

28 samples from lacustrine delta, ten from point bars, and 21 from braided rivers.

$(\mathrm{Q}=$ polycrystalline quartz, $\mathrm{Qm}=$ monocrystalline quartz, $\mathrm{Qt}=$ total quartz, $\mathrm{K}=$ potash feldspar, $P=$ plagioclase feldspar, $F r x=$ feldspar bearing plutonic fragments, $F t=$ total feldspar plus feldspar bearing plutonic fragments, $L v=$ volcanic fragments, $L m=$ metamorphic fragments, $L s=$ sedimentary fragments, $L t=$ total lithic fragments, $A=$ accessories, $M=\operatorname{mica}, M a=$ matrix) 
from Unit B contain lesser amounts of quartz (71.4 percent) than the lacustrine delta sandstones, and larger amounts of feldspar ( 9.6 percent) and 7 ithic fragments (12.0 percent). The braided river sandstones from $C$ contain significantiy larger amounts of feldspar (12.6 percent) and lithic fragments ( 19.0 percent), but contain the least quartz (62.1 percent). This is a direct indicator of depositional energy and/or proximity to the sediment source. As energy is reduced and/or distance from the source is increased, heavy minerals (feldspars and lithic fragments) drop out of the sediment load increasing the quartz to heavy mineral ratio. Therefore, the sands of Unit $C$ (braided stream) represent a higher depositional energy than Unit B (point bar) which represents a higher depositional energy than Unit $A$ (lacustrine delta). This supports the models of deposition postulated for these units and is further supported in the textural analysis which follows.

Texture

The lacustrine delta deposits of Unit A are very fine grained and well sorted. The average mean quartz grain size is $0.10 \mathrm{~mm}$ (very fine sand). The point bar deposits of Unit $B$ have intermediate sand sizes and sorting values. The average mean quartz grain size is $0.28 \mathrm{~mm}$ (medium sand). The braided river deposits of Unit $C$ have the coarsest quartz grain size at the Hanna site and are poorly sorted. The average mean quartz grain size is $0.48 \mathrm{~mm}$ (medium sand). Textural data for the Hanna site is summarized in Table 3. Roundness values for the quartz grains vary from angular to rounded. Textural maturities vary with the environment of deposition. The lacustrine delta sandstones (Unit A) are classified as mature to supermature. The point bar sandstones (Unit B) range from immature to mature-supermature. Samples from the braided river deposits (Unit C) are classified as submature.

In summary, the characteristics of the lacustrine delta sands of Unit $A$ are very fine grained, well sorted, subangular to rounded, with a mature to supermature texture. This is representative of a low energy depositional environment and probably traveled a fair distance from the sediment source. The characteristics of the point bar sands of Unit B are medium grained, moderately sorted, subangular to rounded with a submature to supermature texture. This represents a higher energy environment than represented in Unit $A$ above. The characteristics of the braided river sands of Unit $C$ are medium to coarse grained, poorly sorted, angular to rounded with a submature texture. This represents the highest energy environment of the three units.

\section{Porosity}

Most of the porosity observed in this section is the result of dissolution of grains or cement and is considered secondary (Craig, 1982). The porosity data is summarized in Table 3 and indicates a wide variation in the amount of porosity between the sandstones of each environment. No porosity was noted in point counts of the lacustrine delta (Unit A). Since the sandstones in Unit $A$ are water-bearing (Youngberg and Santoro, 1981) it may be that most of the porosity and 
Table 3. Average textural and porosity values for fifty-nine sandstone samples from the Hanna Formation, Hanna UCG site (after Craig, 1982).

\begin{tabular}{|c|c|c|c|c|c|c|c|}
\hline & $\begin{array}{c}\text { Mean } \\
\text { Quartz } \\
\text { Size } \\
\text { mm }\end{array}$ & $\begin{array}{l}\text { Maximum } \\
\text { Quartz } \\
\text { Size } \\
\text { mm }\end{array}$ & $\begin{array}{l}\text { Standard } \\
\text { Deviation } \\
\text { of Quartz } \\
\text { Size } \mathrm{mm}\end{array}$ & Roundness & $\begin{array}{l}\text { Textural } \\
\text { Maturity }\end{array}$ & $\begin{array}{l}\text { Porosity } \\
\text { Percent }\end{array}$ & $\begin{array}{l}\text { Standard } \\
\text { Deviation } \\
\text { for } \\
\text { Porosity }\end{array}$ \\
\hline $\begin{array}{l}\text { UNIT A } \\
\text { Lacustrine Delta }\end{array}$ & 0.1 & 0.19 & 0.37 & $\begin{array}{l}\text { SubanguTar- } \\
\text { Rounded }\end{array}$ & $\begin{array}{l}\text { Mature- } \\
\text { Supermature }\end{array}$ & 0 & 0 \\
\hline $\begin{array}{l}\text { UNIT B } \\
\text { Point Bars }\end{array}$ & 0.28 & 1.62 & 0.17 & $\begin{array}{l}\text { Subangular- } \\
\text { Rounded }\end{array}$ & $\begin{array}{l}\text { Submature- } \\
\text { Supermature }\end{array}$ & 2.88 & 2.40 \\
\hline $\begin{array}{l}\text { UNIT C } \\
\text { Braided River }\end{array}$ & 0.48 & 1.16 & 0.22 & $\begin{array}{l}\text { Angular- } \\
\text { Rounded }\end{array}$ & Submature & 6.36 & 3.80 \\
\hline
\end{tabular}


permeability in Unit $A$ is due to joints in the rock. The point bar sandstones of Unit $B$ have a porosity of 2.88 percent. The braided river sandstones of Unit $C$ have the highest porosity values with an average of 6.36 percent.

Diagenesis

A number of diagenetic features have been observed in the overburden sandstones at the Hanna UCG site. The most commoniy observed diagenetic processes were compaction and cementation. In some cases porosity has been destroyed by compaction, cementation, and replacement. In other cases, secondary porosity has been created by dissolution of grains of cement (Craig, 1982).

The cement types found in the overburden sandstones are kaolinite, calcite, smectite, siderite, silica, chlorite, and pyrite. Kaolinite cement was present in almost all sandstone samples where it occurs as a pore-filling cement. Calcite in some samples filled all the pores, replacing feldspar grains and the edges of quartz grains. In other samples, calcite occurred as single crystals or small groups of crystals filling in the pore spaces. Siderite was found in sandstones containing significant amounts of clay matrix or clay clasts. Siderite was not found in the sandstones of Unit $C$. Smectite was found sporadically distributed throughout the overburden as a pore lining. Silica was found scattered throughout the overburden in minor amounts. Pyrite and chlorite were found in very few samples in minor concentrations. Pyrite occurred as mass enclosing detrital grains. Chlorite was found as isolated pore fills (Craig, 1982).

COAL

Proximate and UTtimate Analysis

Data for proximate and ultimate analyses on an as received basis are given in Table 4 . The proximate analys is information shows the average moisture content is 8.4 percent, the average ash content is 27.4 percent, the average volatile matter content is 32.7 percent, and the average fixed carbon content is 31.5 percent. Profiles of as received and moisture free analyses for $\mathrm{CH}-133$ are shown in Figures 32 and 33 respectively. A comparison of these two plates shows that the volatile matter decreases while the fixed carbon and ash content increases in the moisture free analysis. The ultimate analysis shows an ash content of 27.4 percent and a sulfur content of 0.7 percent. A profile of a moisture and ash free ultimate analys is for $\mathrm{CH}-133$ is shown in Figure 34. The mineralogy of the ash and the forms of sulfur will be discussed in the following sections. The distributions of total sulfur for cores II4, III-2, and IV-2 are shown in Figures 35,36 and 37 . A concentration of sulfur was found near the top of the coal bed in each corehole.

Some of the 176 samples used for the figures in Table 4 contained ash contents of up to 75.9 percent. Although these figures give a true representation of what the coal seam is like that was gasified, some of 
Table 4. Summary of proximate, ultimate and calorific value analyses of coal from the Hanna UCG site.

\begin{tabular}{|c|c|c|c|c|c|}
\hline & $\begin{array}{l}\text { Number of } \\
\text { Samples }\end{array}$ & Mean & $\begin{array}{l}\text { Standard } \\
\text { Deviation }\end{array}$ & Maximum & Minimum \\
\hline \multicolumn{6}{|c|}{$\begin{array}{l}\text { Proximate Analysis Percent } \\
\text { (as received) }\end{array}$} \\
\hline $\begin{array}{l}\text { Moisture } \\
\text { Ash } \\
\text { Volatile Matter } \\
\text { Fixed Carbon }\end{array}$ & $\begin{array}{l}176 \\
176 \\
176 \\
176\end{array}$ & $\begin{array}{r}8.4 \\
27.4 \\
32.7 \\
37.5\end{array}$ & $\begin{array}{r}1.22 \\
18.56 \\
7.65 \\
11.05\end{array}$ & $\begin{array}{l}11.7 \\
75.9 \\
49.9 \\
49.2\end{array}$ & $\begin{array}{r}4.3 \\
3.4 \\
11.0 \\
1.2\end{array}$ \\
\hline \multicolumn{6}{|c|}{$\begin{array}{l}\text { Ultimate Analysis Percent } \\
\text { (as received }\end{array}$} \\
\hline $\begin{array}{l}\text { Moisture } \\
\text { Carbon } \\
\text { Hydrogen } \\
\text { Nitrogen } \\
\text { Sulfur } \\
\text { Ash } \\
\text { Oxygen }\end{array}$ & $\begin{array}{l}176 \\
176 \\
176 \\
176 \\
176 \\
176 \\
176\end{array}$ & $\begin{array}{r}8.4 \\
46.7 \\
4.3 \\
1.1 \\
0.7 \\
27.4 \\
11.4\end{array}$ & $\begin{array}{r}1.22 \\
14.49 \\
1.11 \\
0.33 \\
0.56 \\
18.56 \\
4.79\end{array}$ & $\begin{array}{r}17.7 \\
67.7 \\
6.0 \\
1.7 \\
3.9 \\
75.9 \\
23.5\end{array}$ & $\begin{array}{r}4.3 \\
11.8 \\
1.6 \\
0.1 \\
0.1 \\
3.4 \\
6.0\end{array}$ \\
\hline $\begin{array}{l}\text { Calorific Value } \\
\text { (BTU/LB) }\end{array}$ & 176 & 8,196 & 2,656 & 12,060 & 1,930 \\
\hline
\end{tabular}




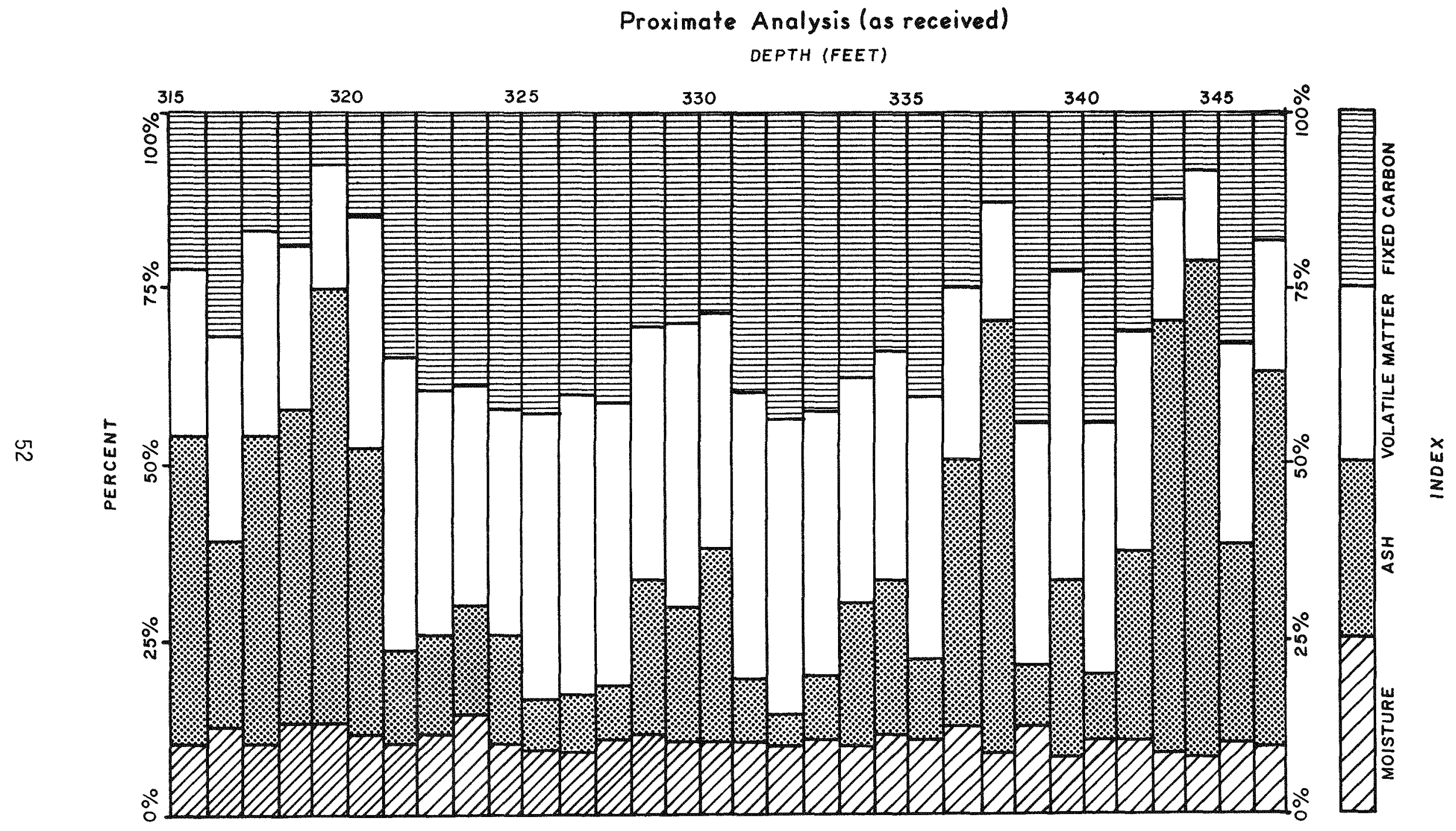

Figure 32. As received proximate analys is for $\mathrm{CH}-133$, Hanna UCG site. 
PROXIMATE ANALYSIS (MOISTURE FREE)

Depth (feet)

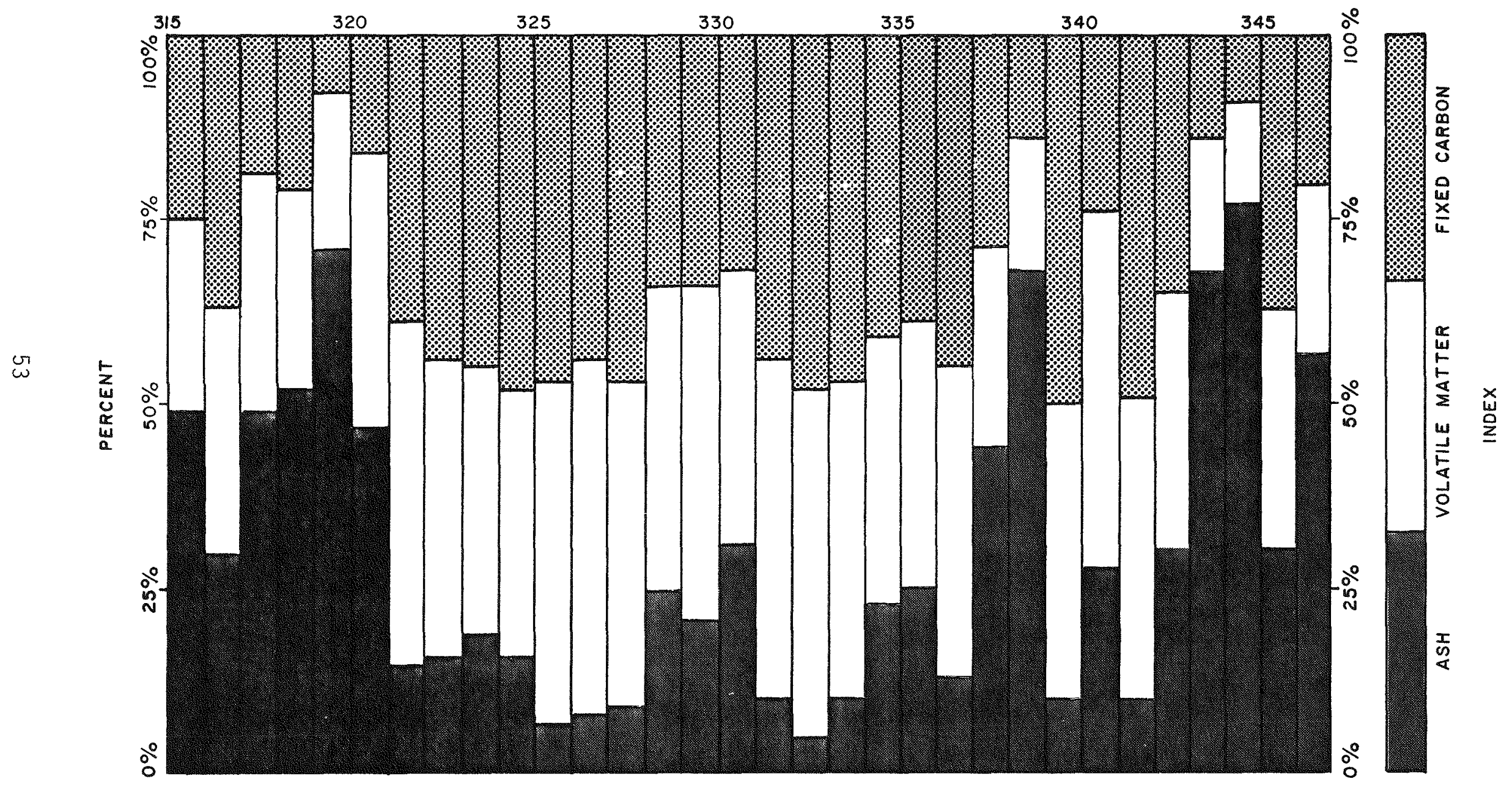

Figure 33. Moisture-free proximate analys is for $\mathrm{CH}-133$, Hanna UCG site. 
ULTIMATE ANALYSIS (MOISTURE AND ASH-FREE)

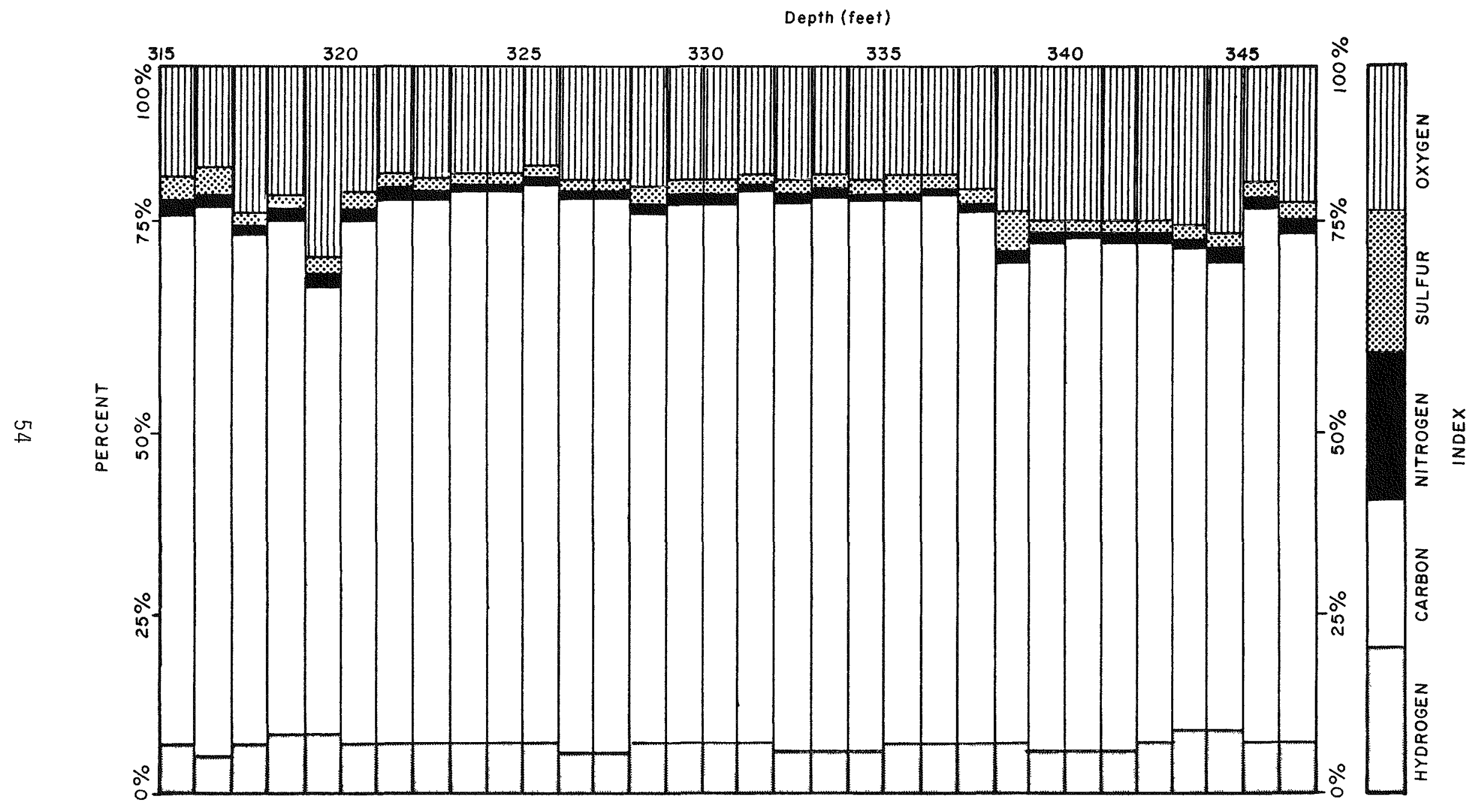

Figure 34. Moisture and ash-free ultimate analysis for $\mathrm{CH}-133$, Hanna UCG site. 


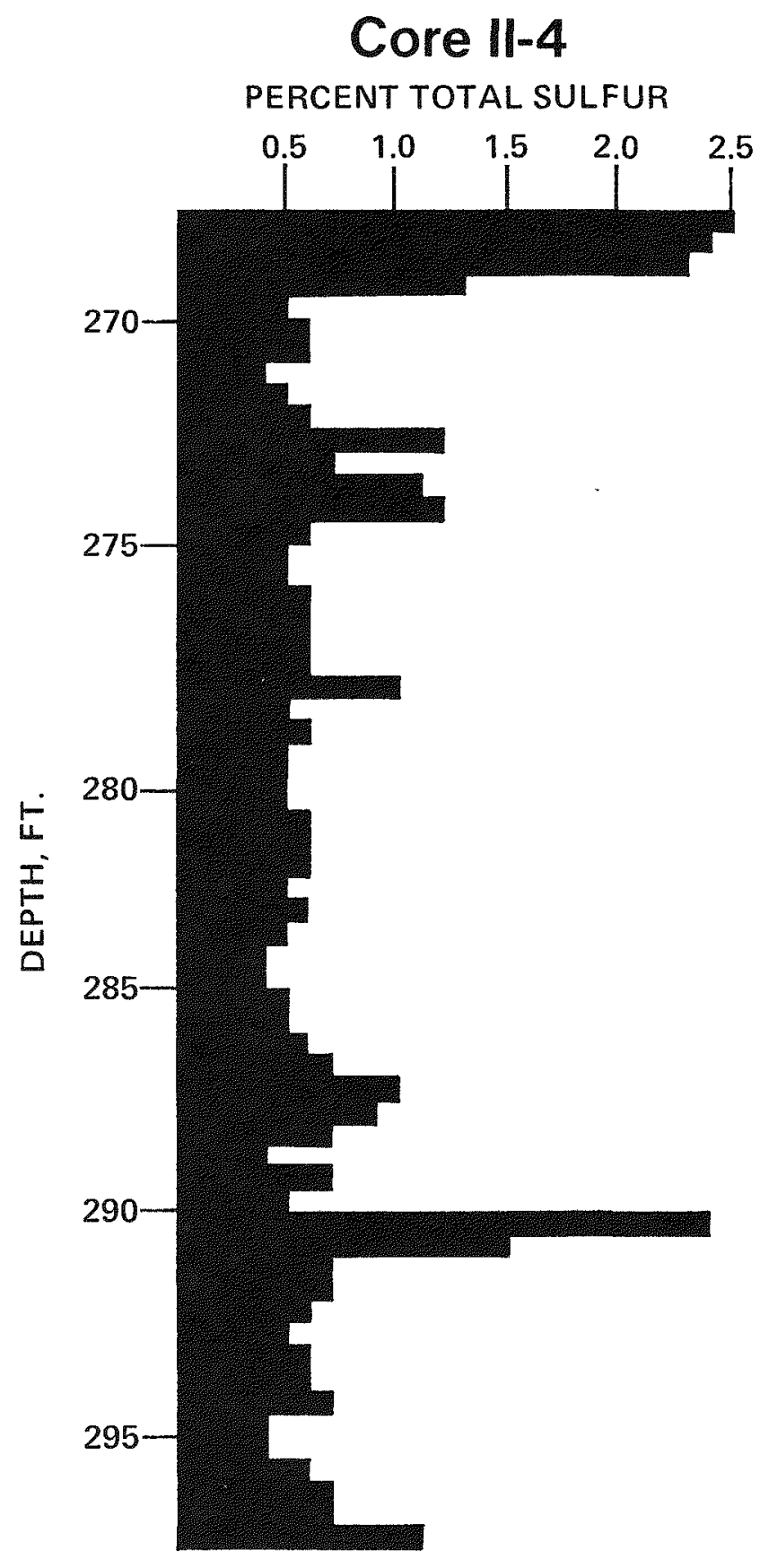

Figure 35. Distribution of total sulfur in Hanna No. 1 coal for Corehole II-4, Hanna UCG Site. 


\section{Core III-2}

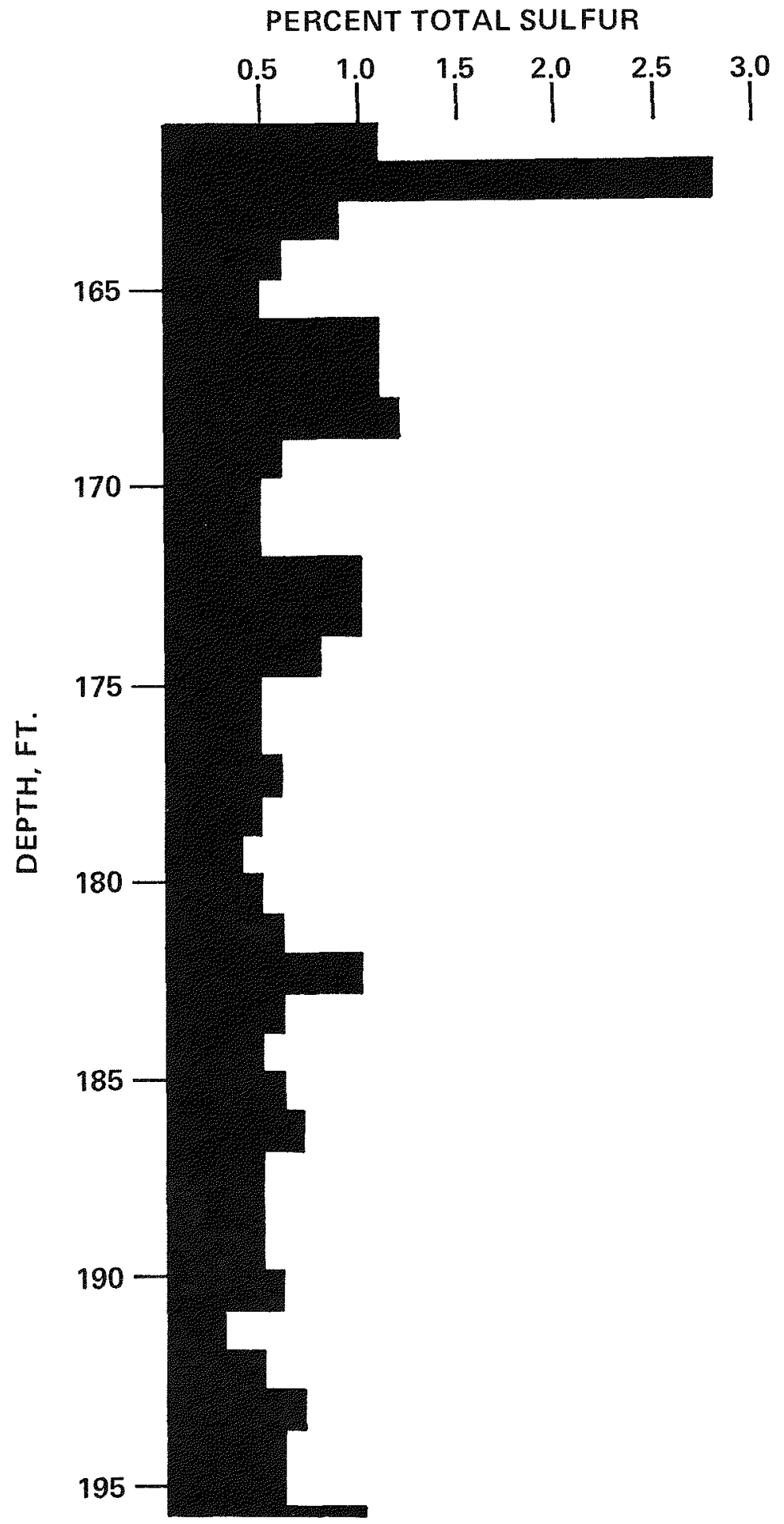

Figure 36. Distribution of total sulfur in Hanna No. 1 coal for Corehole III-2, Hanna UCG site. 


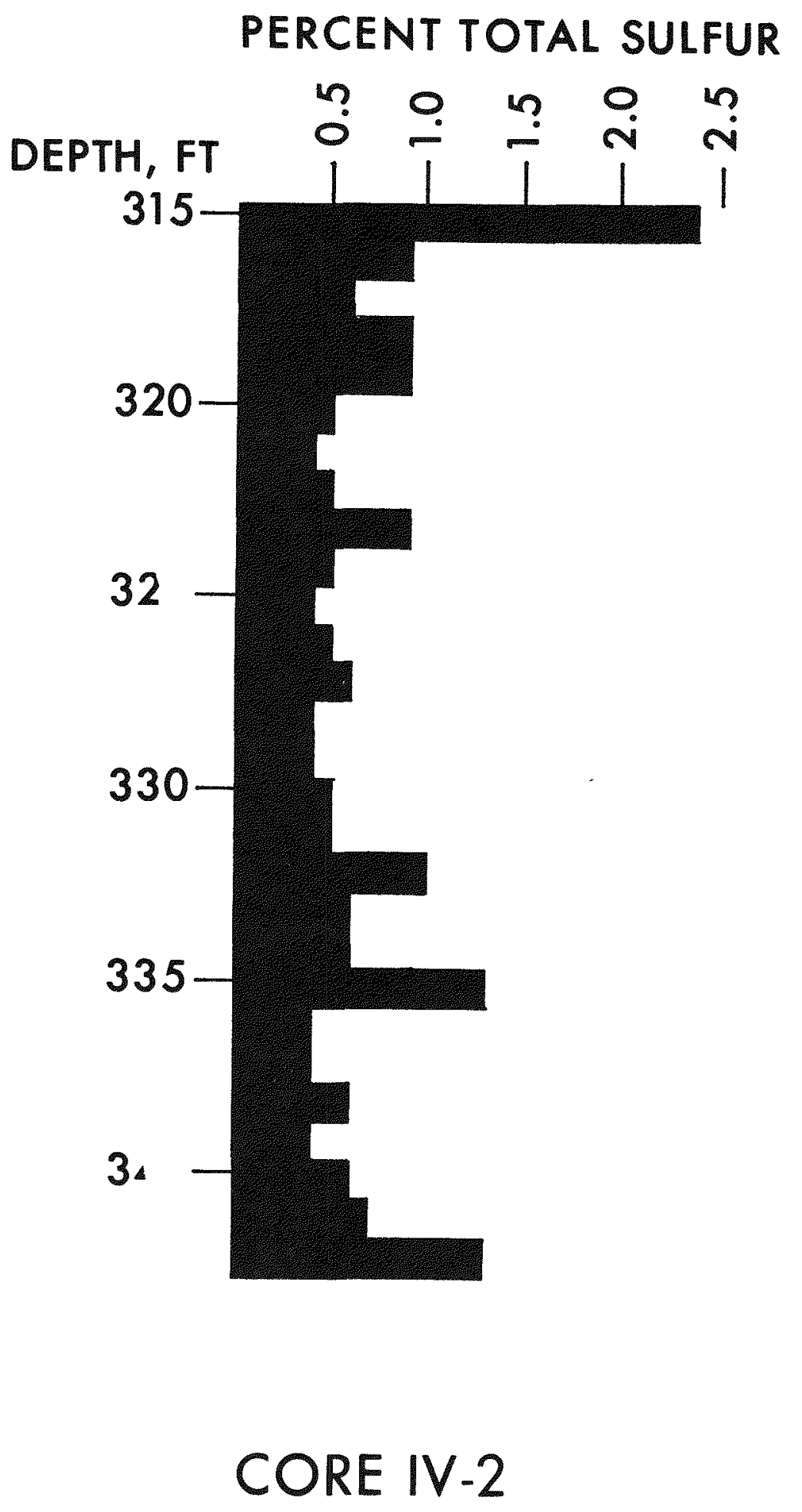

Figure 37. Distribution of total sulfur in Hanna No. 1 coal for Corehole IV-2, Hanna UCG site. 
Table 5. *Ash percentage values for six coreholes at the Hanna UCG site.

\begin{tabular}{llllll} 
Corehole & Mean & High & Low & Top 5 ft. & Bottom 5 ft. \\
\hline CH-133 & $30.42 \%$ & $76.7 \%$ & $5.1 \%$ & $50.06 \%$ & $52.70 \%$ \\
2HP-170 & $29.40 \%$ & $68.1 \%$ & $5.2 \%$ & $42.34 \%$ & $35.04 \%$ \\
I -16 & $25.57 \%$ & $78.7 \%$ & $3.8 \%$ & $26.74 \%$ & $64.52 \%$ \\
I II -2 & $32.38 \%$ & $73.6 \%$ & $5.9 \%$ & $53.96 \%$ & $33.80 \%$ \\
IV -2 & $28.28 \%$ & $64.4 \%$ & $5.5 \%$ & $38.66 \%$ & $39.48 \%$ \\
II -4 & $30.79 \%$ & $78.9 \%$ & $3.7 \%$ & $34.04 \%$ & $52.40 \%$ \\
\hline
\end{tabular}

* Moisture-free basis

the high ash content coals can be classified as carbonaceous shale rather than coal. Table 5 shows mean, high, low, top five feet and bottom five feet ash percent values for six coreholes in the Hanna UCG area.

Ash Analys is

The mineralogy of the Hanna No. 1 coal bed is shown in Figure 38. This chart illustrates the relative abundance of mineral constituents in the ash of the coal after most of the free carbon has been burned off. As expected for coal, a low energy sedimentary deposit, fine-grained clay minerals (kaolinite and illite) make up nearly half of the coal ash. Quartz is the next most abundant mineral at 18.1 percent. This is quite different from the pattern of the overburden where quartz makes up over half of the total and clay minerals are only 8.9 percent of the mineral constituents (see Figure 26).

Figure 39 shows an even distribution of calcite/aragonite minerals throughout the coal bed of core I-16. The concentration of calcium appears to be unrelated to ash concentration. Field observations support the idea that calcite in the coal is a secondary fracture filling occurrence. Sulfur distribution (Figures 35-37 and Appendix B) is concentrated at the top and bottom of the coal and seems to be directiy related to ash content. The direct relationship between ash percentage and element concentrations is valid for nearly all elements (compare profiles in Appendix B).

The oxides comprising the ash of the Hanna bituminous coals are shown in Table 6 . The most abundant oxide in the ash is silicon dioxide with a mean level of almost 47 percent. The least common occurring oxide is manganese oxide with a mean level of 0.11 percent. The highest value is found for iron oxide (71.53 percent). The distribution and mineral form of iron oxide for the coal bed in Core I-16 is shown in Figure 40. Note the rather even distribution of pyrite through the bed with a large concentration of siderite in the middle of the bed. A profile of an ash analysis of oxides for $\mathrm{CH}-133$ is shown in Figure 41. 


\section{Minerals Identified in Hanna I Coal Bed (Low Temperature Ash)}

\begin{tabular}{|c|c|c|c|c|}
\hline & \multicolumn{4}{|c|}{ PERCENT } \\
\hline & 0 & 10 & 20 & \\
\hline KAOLINITE & E & & & $23.5 \%$ \\
\hline ILLITE & 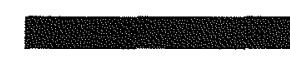 & & & $22.6 \%$ \\
\hline QUARTZ & 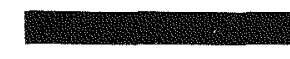 & & $.1 \%$ & \\
\hline K-FELDSPAR & $3.1 \%$ & & & \\
\hline GYPSUM & $2.9 \%$ & & & \\
\hline ARAGONITE & $2.0 \%$ & & & \\
\hline SIDERITE & $1.5 \%$ & & & \\
\hline CALCITE & $1.4 \%$ & & & \\
\hline PYRITE & $0.8 \%$ & & & \\
\hline PLAGIOCLASE & $0.8 \%$ & & & \\
\hline RUTILE & $0.5 \%$ & & & \\
\hline GOETHITE & $0.2 \%$ & & & \\
\hline UNIDENTIFIED & & & & $.6 \%$ \\
\hline
\end{tabular}

Figure 38. Minerals in the Hanna No. 1 coal bed (low temperature ash), Hanna UCG site. 


\section{Distribution of Calcite/Aragonite Minerals in Coal Bed Core I-16}

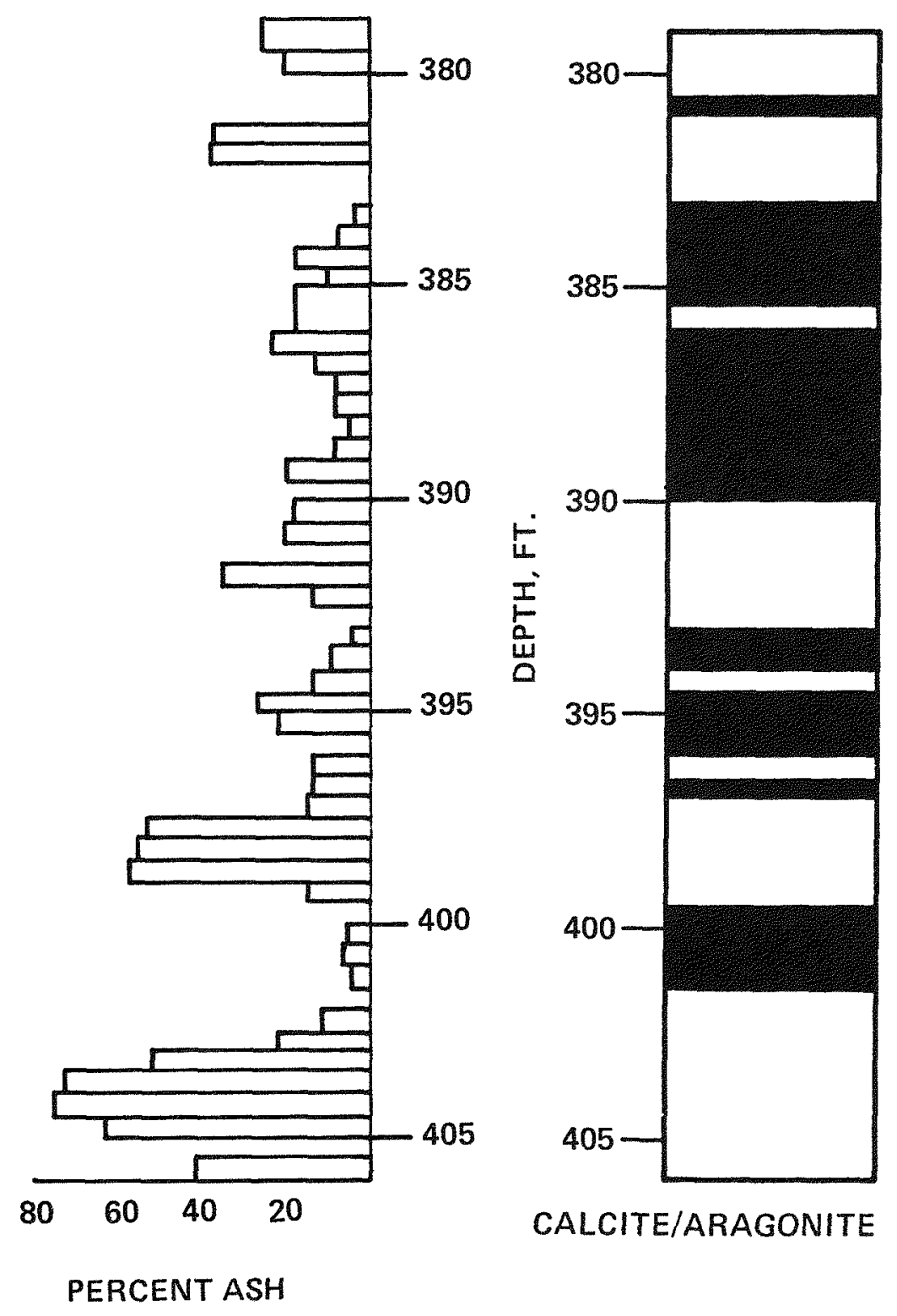

Figure 39. Distribution of calcite/aragonite minerals in the Hanna No. 1 coal bed for Corehole I-16, Hanna UCG site. 


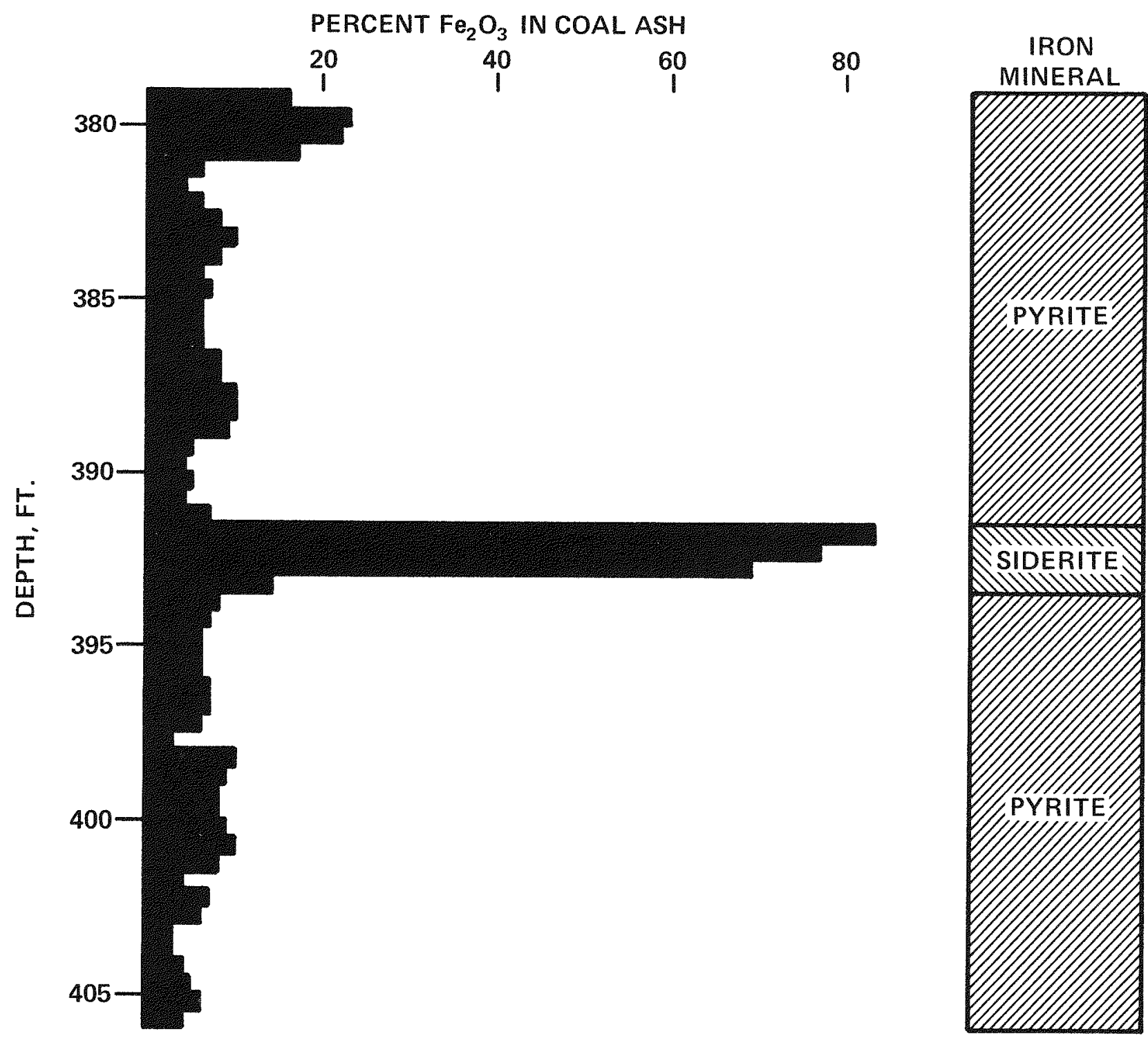

Figure 40. Distribution and mineral form of iron in the Hanna No. 1 coal in Corehole I-16, Hanna UCG site. 


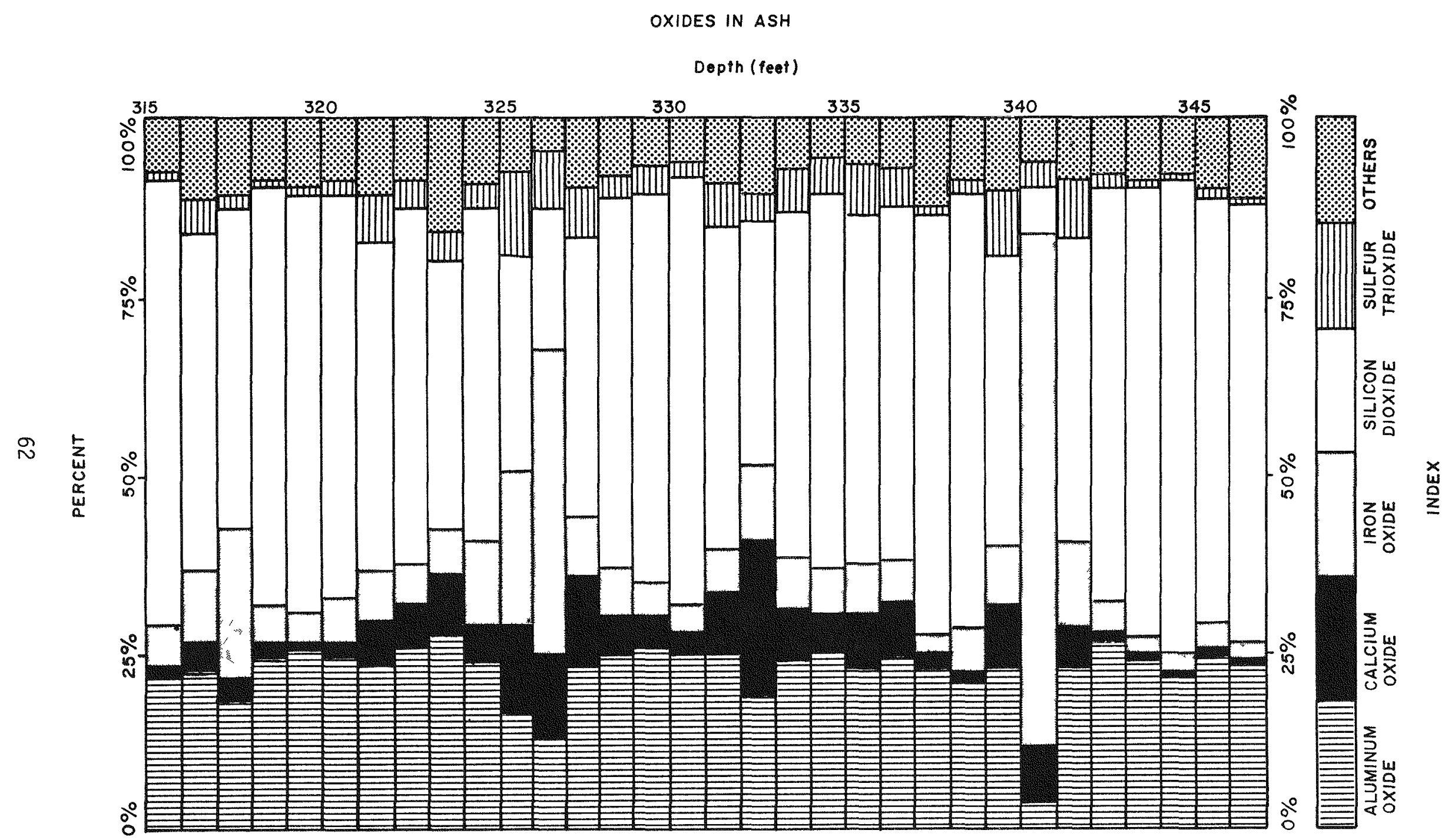

Figure 41. Ash analys is of oxides for $\mathrm{CH}-133$, Hanna UCG site. 
An elemental analysis of the ash of Hanna bituminous coal is shown in Table 7. The most abundant elements are chlorine, flourine, and phosphorous with mean concentrations close to $100 \mathrm{ppm}$. Gold and mercury are the least common elements with mean concentrations of 0.02 and 0.01 ppm respectively. A comparison of concentrations of some of the elements in Table 7 for coal and carbonaceous shale in core $2 \mathrm{HP}-170$ is shown in Figure 42. The concentrations of 2.11 elements except calcium is greater in the carbonaceous shale as compared to the coal.

Table 6. Oxides in ash of Hanna bituminous coals.

\begin{tabular}{lccccc}
\hline Oxide & \# Samples & High\% & Low\% & Mean\% & $\begin{array}{c}\text { Standard } \\
\text { Deviation } \%\end{array}$ \\
\hline $\mathrm{SiO}_{2}$ & 64 & 66.22 & 6.61 & 46.92 & 11.10 \\
$\mathrm{AT}_{2} \mathrm{O}_{3}$ & 64 & 28.25 & 3.32 & 22.49 & 4.20 \\
$\mathrm{Fe}_{2} \mathrm{O}_{3}$ & 64 & 71.53 & 3.01 & 10.30 & 11.39 \\
$\mathrm{CaO}^{2}$ & 64 & 21.95 & 0.34 & 7.23 & 4.44 \\
$\mathrm{SO}_{3}$ & 64 & 12.66 & 0.29 & 4.80 & 3.04 \\
$\mathrm{MgO}$ & 64 & 5.87 & 1.49 & 2.43 & 0.76 \\
$\mathrm{Na}_{2} \mathrm{O}_{2}$ & 64 & 2.92 & 0.84 & 1.33 & 0.47 \\
$\mathrm{~K}_{2} \mathrm{O}^{2}$ & 64 & 2.83 & 0.19 & 1.26 & 0.43 \\
$\mathrm{TiO}_{2}$ & 64 & 1.99 & 0.13 & 0.84 & 0.27 \\
$\mathrm{P}_{2} \mathrm{O}_{5}$ & 64 & 6.15 & 0.01 & 0.78 & 1.14 \\
$\mathrm{MnO}_{2}$ & 64 & 1.88 & 0.0 & 0.11 & 0.33 \\
\hline
\end{tabular}


Table 7. Element analysis of Hanna bituminous coals.

\begin{tabular}{|c|c|c|c|c|c|}
\hline Element & \# Samples & High (ppm) & Low (ppm) & $\operatorname{Mean}(\mathrm{ppm})$ & $\begin{array}{l}\text { Standard } \\
\text { Deviation }\end{array}$ \\
\hline ATuminum & 64 & 10 & 0.2 & 2.84 & 1.82 \\
\hline Antimony & 64 & 65 & $<1.0$ & 16.94 & 21.99 \\
\hline Arsenic & 64 & $<10$ & $<10$ & 10 & 0.0 \\
\hline Bismuth & 64 & $<5$ & $<5$ & 5 & 0.0 \\
\hline Cadmium & 64 & $<5$ & $<5$ & 5 & 0.0 \\
\hline Calcium & 64 & 3.6 & 0.03 & 0.47 & 0.47 \\
\hline Chlorine & 64 & $<100$ & $<100$ & 100 & 0.0 \\
\hline Copper (oxide) & 64 & 79 & $<3$ & 9.2 & 14.41 \\
\hline Copper (sulfide) & 64 & 70 & $<3$ & 12.89 & 10.81 \\
\hline Flourine & 64 & 100 & 10 & 98.59 & 11.16 \\
\hline Gold & 64 & 0.02 & $<0.01$ & 0.02 & 0.02 \\
\hline Heavy Metals & 64 & $<1.0$ & $<0.3$ & 0.60 & 0.21 \\
\hline Indium & 64 & $<1.0$ & $<1.0$ & 1.0 & 0.0 \\
\hline Iron (ferrous) & 64 & 3.5 & 0.05 & 0.84 & 0.76 \\
\hline Lead & 64 & 70 & 7 & 22.52 & 11.84 \\
\hline Lead Oxide & 64 & 49 & $<3$ & 9.95 & 10.27 \\
\hline Lead Sulfide & 64 & 73 & $<3$ & 16.67 & 13.67 \\
\hline Lithium & 64 & 220 & $<1$ & 35.13 & 50.13 \\
\hline Magnesium & 64 & 1.25 & 0.09 & 0.36 & 0.18 \\
\hline Mercury & 64 & 0.01 & $<0.01$ & 0.01 & -- \\
\hline Molybdenum(oxide) & 64 & 3.0 & $<3.0$ & 3.0 & 0.0 \\
\hline Molybdenum (sulfide & e) 64 & $<3.0$ & $<3.0$ & 3.0 & 0.0 \\
\hline Phosphorous & 64 & 351 & $<50$ & 96.91 & 74.87 \\
\hline Potassium & 64 & 1.87 & 0.02 & 0.31 & 0.29 \\
\hline Rubidium & 64 & 160 & $<1.0$ & 5.78 & 26.85 \\
\hline Selenium & 64 & $<50$ & $<1$ & 2.73 & 6.0 \\
\hline Silica & 64 & 15.0 & 0.03 & 1.46 & 2.70 \\
\hline Sodium & 64 & 3.0 & 0.1 & 0.60 & 0.49 \\
\hline Sulfate & 64 & 5.35 & 0.21 & 2.08 & 0.79 \\
\hline Sulfur (total) & 64 & 2.61 & 0.31 & 0.79 & 0.42 \\
\hline Sulfide & 64 & 1.9 & 0.1 & 0.51 & 0.33 \\
\hline Sulfur (soluble) & 64 & 1.25 & 0.16 & 0.54 & 0.29 \\
\hline Tellurium & 64 & 0.1 & $<0.1$ & 0.1 & 0.0 \\
\hline Thallium & 64 & $<10$ & $<1$ & 1.14 & 1.13 \\
\hline Tin & 64 & $<10$ & $<10$ & 10 & 0.0 \\
\hline Tungsten & 64 & 2 & $<2.0$ & 2.0 & 0.0 \\
\hline Uranium & 64 & 4 & $<2.0$ & 2.31 & 0.61 \\
\hline Zinc & 64 & 105 & 14 & 64.69 & 29.29 \\
\hline Zinc (oxide) & 64 & 56 & $<3.0$ & 19.58 & 15.64 \\
\hline Zinc (sulfide) & 64 & 111 & $<3.0$ & 51.09 & 37.44 \\
\hline
\end{tabular}




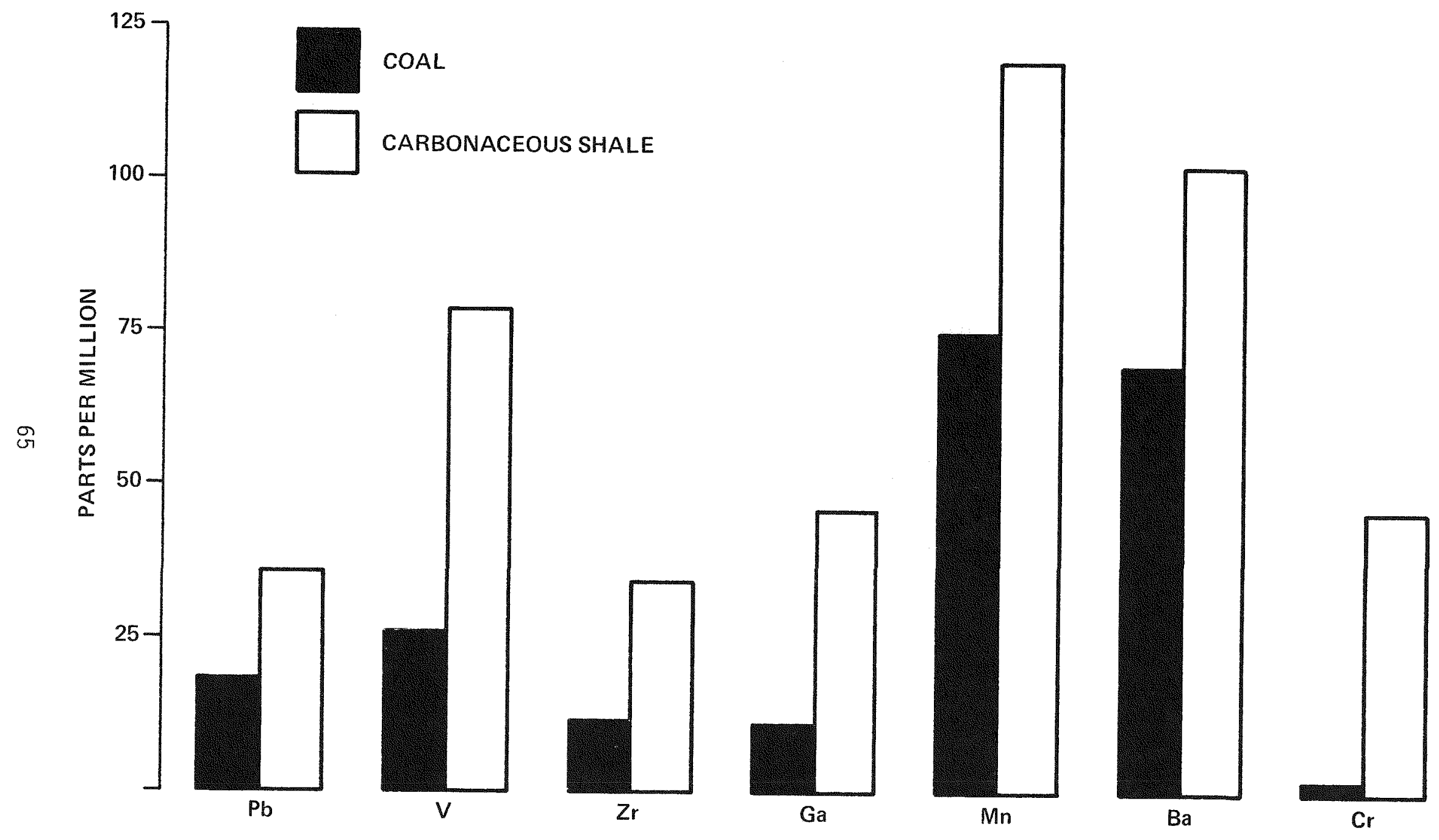

Figure 42. Element concentration of coal vs, carbonaceous shale in Corehole 2HP-170, Hanna UCG site. (continued next page) 

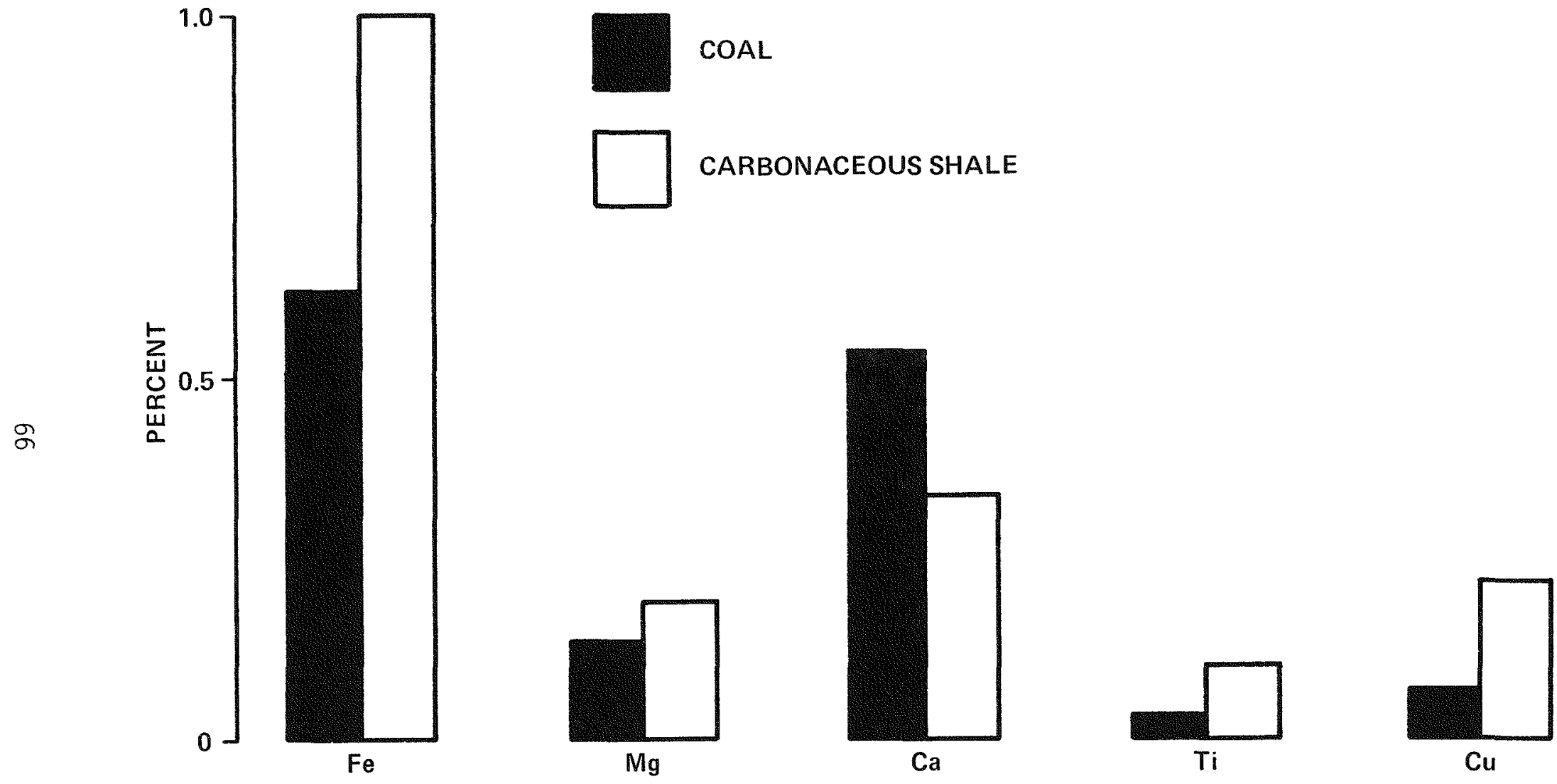

Figure 42. Continued 
Forms of Sulfur

Three forms of sulfur were analyzed for in coal samples. These are: 1) organic, 2) pyritic, and 3) sulfate sulfur. Pyrite in Hanna coal will be discussed in later paragraphs. Data was available for these three sulfur forms in 278 samples taken at one foot intervals from several coreholes around the Hanna UCG Site. These values were analyzed to show the average percentage of each sulfur form in the Hanna No. 1 coal bed at the Hanna UCG site. The results are shown in Table 8 along with high and low value for each form. High total sulfur values were usually caused by an anomalously high pyritic sulfur value (compare Figures 43, 44 \& 46). The "As Received" values were used.

Table 8. Sulfur forms in Hanna No. 1 coal bed.

\begin{tabular}{llll}
\hline & Average & High & Low \\
\hline Organic & $0.44 \%$ & $1.55 \%$ & $0.0 \%$ \\
Pyritic & $0.19 \%$ & $3.38 \%$ & $0.02 \%$ \\
Sulfate & $\underline{0.01 \%}$ & $\underline{0.18 \%}$ & $0.0 \%$ \\
Total & $0.64 \%$ & $3.88 \%$ & $0.08 \%$
\end{tabular}

Generally speaking, about two-thirds of the sulfur present in the Hanna coal is in organic form. The other one third is in pyritic form with only traces of sulfate present. The distributions of organic, pyritic, sulfate and total sulfur for the Hanna No. 1 coal bed in Core I-16 are shown in Figures 43-46. The average total sulfur obtained from the 278 samples is very close to the percentage listed on the ultimate analysis table (Table 4) for 176 samples ( 0.64 percent as compared to 0.7 percent).

Although the average values show organic sulfur as the most abundant sulfur form, the largest value is that for pyritic sulfur and that at least some pyritic sulfur was present in 277278 samples.

An analysis of pyrite forms in Hanna coal is shown in Table 9. The analysis was done on 34 core samples from several holes dritled on the Hanna UCG site. Seven types of pyrite were identified and included: 1) irregular, 2) dispersed euhedra, 3) clustered euhedra, 4) fracture filling, 5) blebs, 6) framboids, and 7) dendritic. No cell filling pyrite was found in the 34 samples. Dispersed euhedra pyrite was the most widespread followed by clustered euhedra and irregular pyrite. Examples of some of these pyrite forms are shown in Figure 47. 


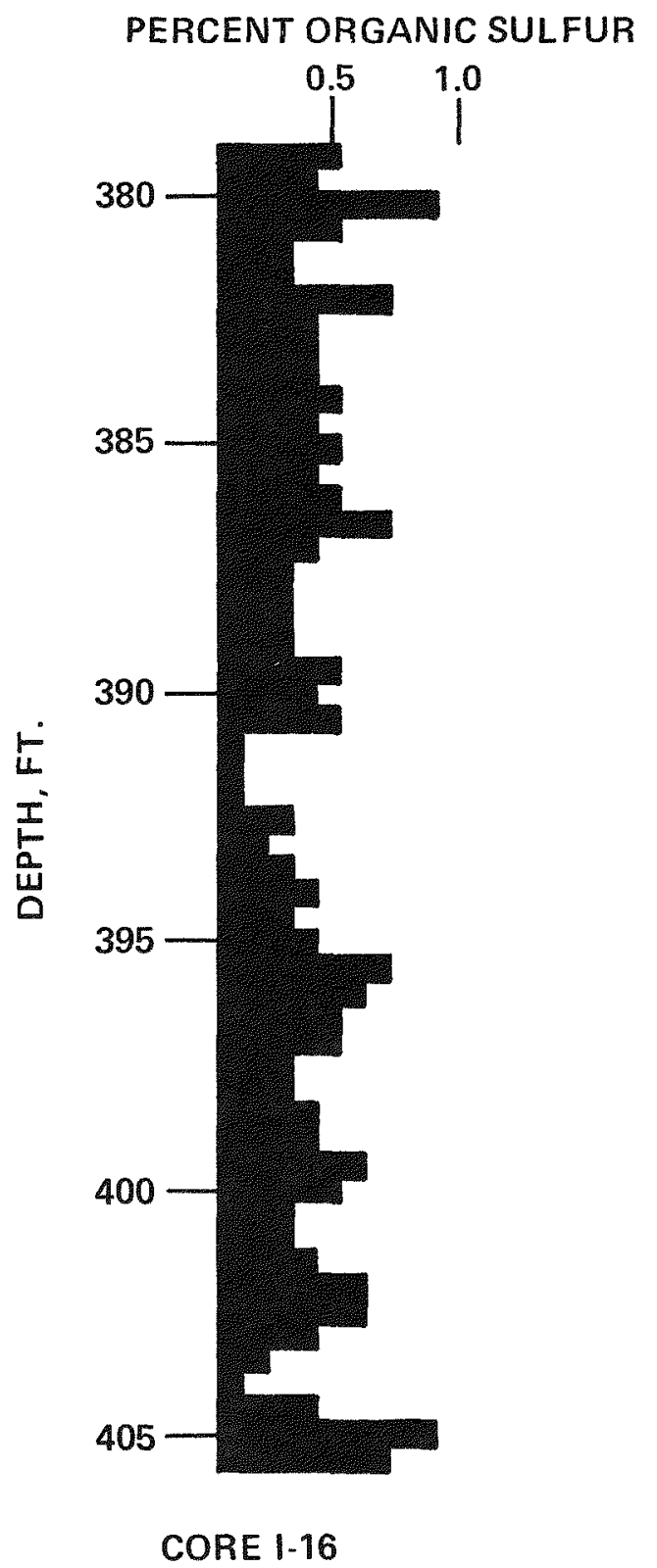

Figure 43. Distribution of organic sulfur in the Hanna No. 1 coal for Corehole I-16, Hanna UCG site. 


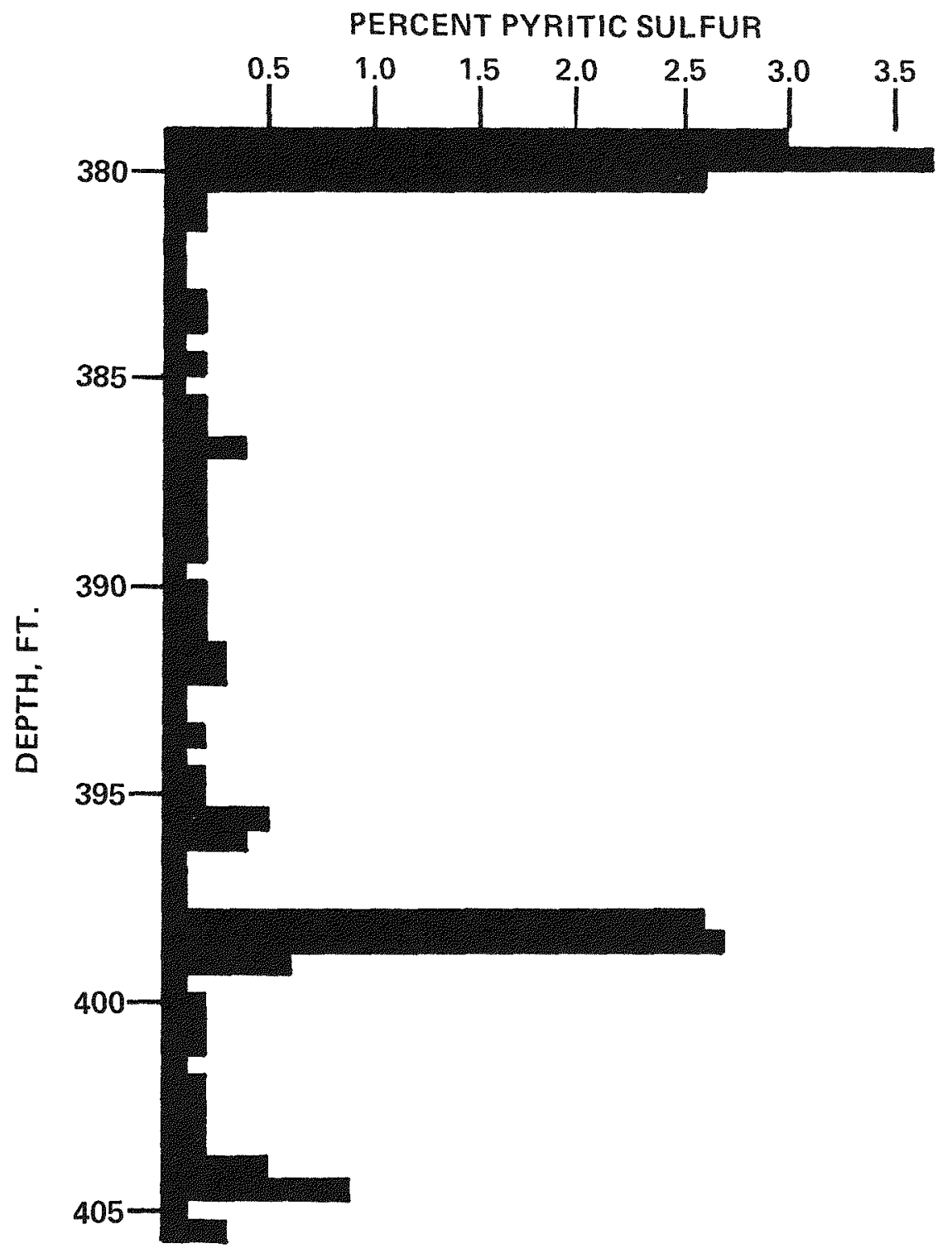

CORE I-16

Figure 44. Distribution of pyritic sulfur in the Hanna No. 1 coal for Corehole 1-16. Hanna UCG site. 


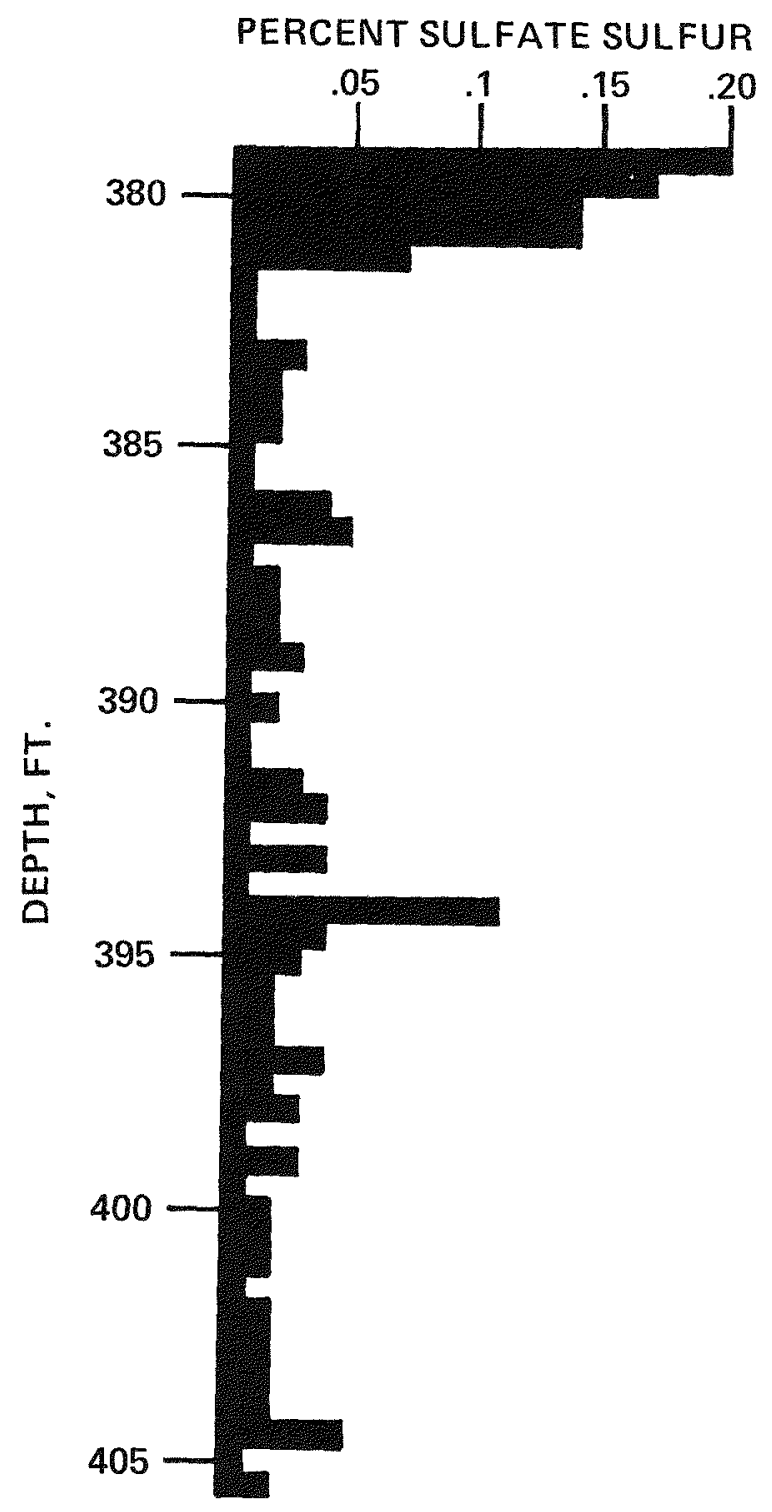

CORE I-16

Figure 45. Distribution of sulfate sulfure in the Hanna No. I coal for Corehole I-16, Hanna UCG site. 


\section{Core I-16}

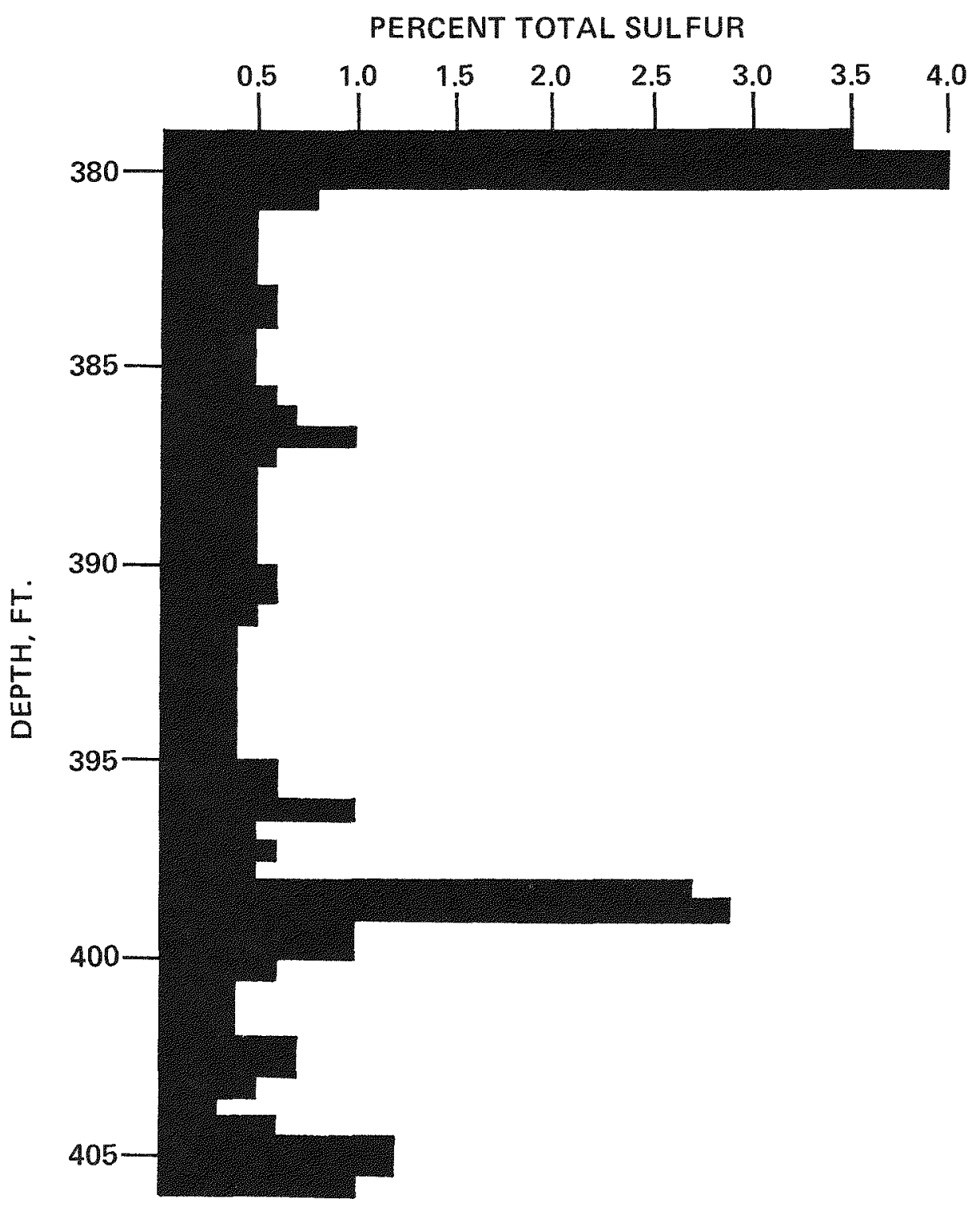

Figure 46. Distribution of total sulfur in the Hanna No. 1 coal for Corehole [-16, Hanna UCG site. 
Table 9. Analys is of pyrite forms in Hanna No. 1 coals. (Mean Values)

\begin{tabular}{|c|c|c|c|c|c|c|c|c|}
\hline & Irreguiar & $\begin{array}{l}\text { Dispersed } \\
\text { Euhedra }\end{array}$ & $\begin{array}{l}\text { Clustered } \\
\text { Euhedra }\end{array}$ & $\begin{array}{l}\text { Fracture } \\
\text { Filling }\end{array}$ & Blebs & Framboids & $\begin{array}{c}\text { Cell } \\
\text { Filling }\end{array}$ & Dendritic \\
\hline Total Area & $5,337.62$ & & & & & & & \\
\hline Area (Microns) & 854.79 & 21.96 & $2,168.09$ & 105.35 & $1,935.97$ & 90.06 & 0.0 & 0.18 \\
\hline$\%$ of Total Area & 14.34 & 40.03 & 21.71 & 8.31 & 4.42 & 2.37 & 0.0 & 0.0 \\
\hline Total Occurrences & 12.26 & & & & & & & \\
\hline Occurrence & 1.21 & 5.35 & 2.47 & 0.21 & 0.97 & 0.46 & 0.0 & 0.0 \\
\hline $\begin{array}{l}\% \text { of Total } \\
\text { Occurrences }\end{array}$ & 8.61 & 62.17 & 11.08 & 2.24 & 5.54 & 1.56 & 0.0 & 0.0 \\
\hline Volume \% & 1.11 & & & & & & & \\
\hline
\end{tabular}

(Analysis done on 34 core samples from holes drit7ed on Hanna UCG Site)

NOTE: The values on this chart are mean values of evenly weighted samples which have greatly varying total areas and total occurrences. 


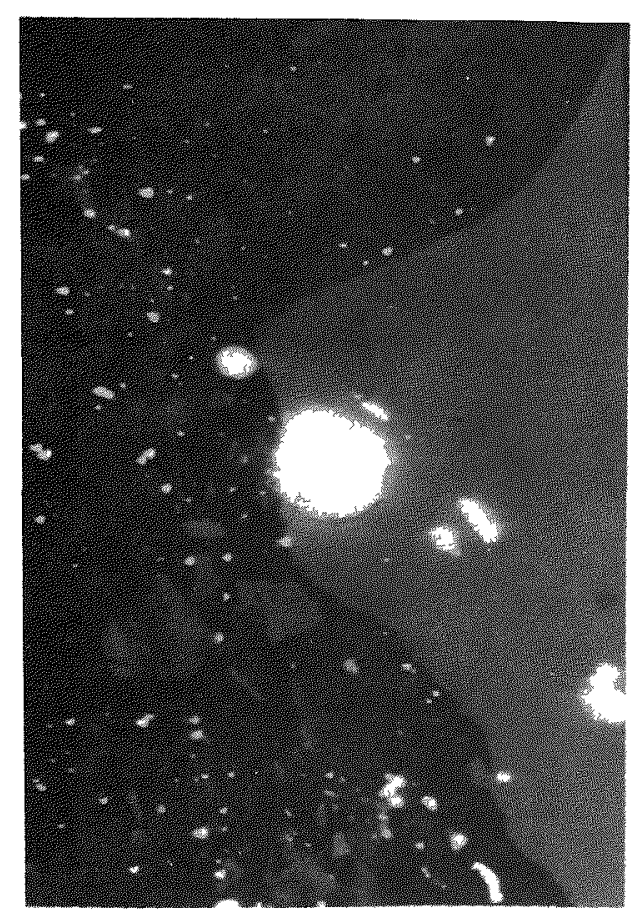

a

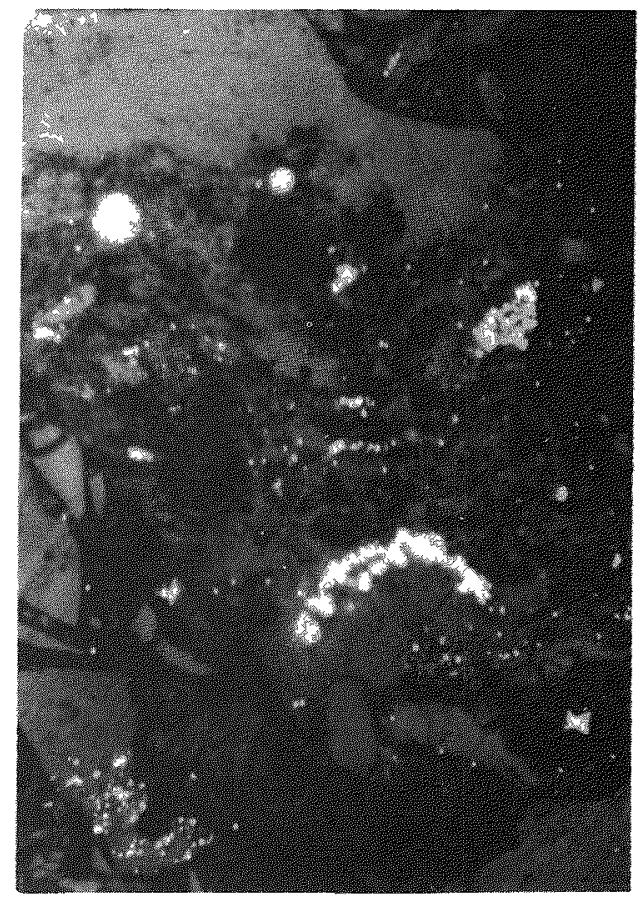

b

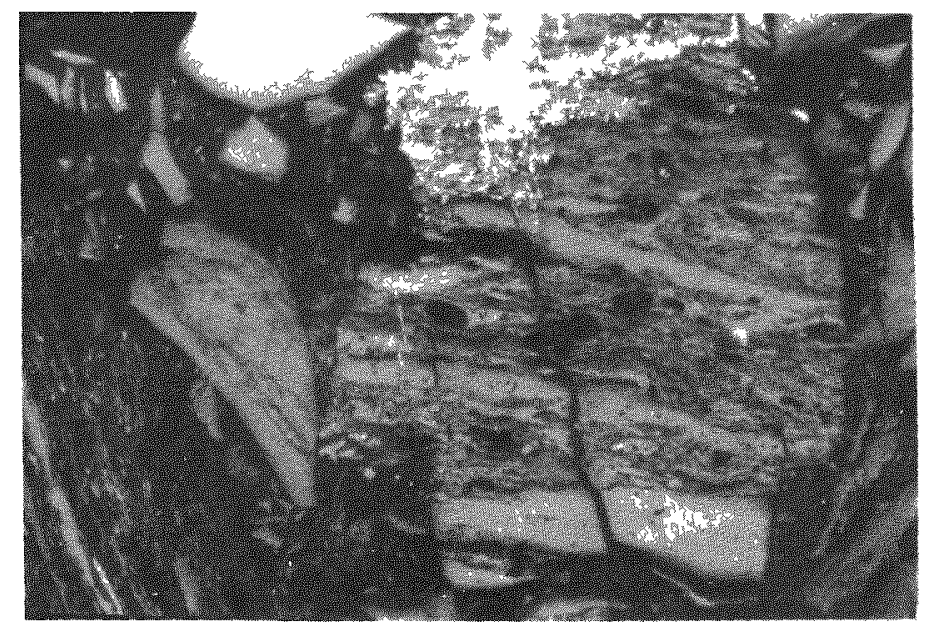

c

Figure 47. Pyrite forms in the Hanna No. 1 coal, Hanna UCG site.

a) framboid (center) and dispersed euhedra

b) framboid (upper left) and clustered euhedra

c) fracture filling 
Maceral Analysis

The maceral classification system used by many laboratories is shown in Table 10. This classification system organizes macerals into three primary groups: vitrinite, exinite, and inertinite. Each maceral group is subdivided into many individual macerals on the basis of their optical properties, morphology, source material, and nature of formation.

The vitrinite group is the most abundant suite of macerals. It is composed primarily of coalified woody tissue derived from stems, roots, and vascular tissues of leaves (Figure $48 \mathrm{a}, \mathrm{c}$ ). Vitrinites occur in coal as bright, thin bands, lenses, and attrital matrix. In reflected light vitrinites appear light to dark grey. The differences in reflectance of vitrinite are due to different plant materials and to different degrees of preservation of the plant material. The carbon and hydrogen content of vitrinites at any given rank are intermediate between those of the exinite and inertinite groups. Vitrinite reacts during carbonization (i.e. coking) to form the bulk of the char mass.

The second group of macerals is the exinite group (Figure $48 b, c$ ) derived from the waxy and resinous parts of plants such as cuticles, spore and pollen exines, resins, and algal remains. The exinite group appears grey, dark grey, or black in reflected light. Exinites have the highest hydrogen content and the lowest carbon content among the maceral groups. During the carbonization process most of the exinite macerals devolatilize as gases or tars.

The third group of macerais is the inertinite group (Figure $48 b, d$ ) derived from plant material that was highly altered and degraded in the peat stage of coal formation (i.e. fossil charcoal). The inertinites appear bright yellow or white in reflected light. Inertinites contain the highest carbon content and lowest hydrogen content of the maceral groups. The inertinite group is inert or semi-inert during the carbonization process and becomes physically incorporated into the char mass.

The following method, standard in most U.S. Taboratories, was used for determining maceral composition. A petrographic examination of polished coal pellets was made in reflected light using an oil immersion lens. The relative abundance of macerals was obtained by a point-count method. Five hundred point counts were made on each of two specimens made from the same coal sample, for a total of one thousand maceral determinations per sample. The data were combined and reported as volume percentages. Table 11 lists the macerals and volume percent for each maceral that was determined for the Hanna No. 1 coal seam. One hundred and eight coal samples were analyzed for maceral composition from the Hanna site. A profile of a maceral analysis of $\mathrm{CH}-133$ is shown in Figure 49. A profile of vitrinoid types in $\mathrm{CH}-133$ is shown in Figure 50. The maceral types in $\mathrm{CH}-133$ are consistent through the coal bed (Figure 49), while the vitrinoid types are more irregular (Figure 50). 
Table 10. Maceral classification describing the macerals that were studied at the Hanna underground coal gasification site.

\begin{tabular}{|c|c|c|c|c|}
\hline \multicolumn{5}{|c|}{ MACERAL CLASSIFICATION } \\
\hline Maceral Group & Maceral & Origin & Chemistry & $\begin{array}{c}\text { Carbonization } \\
\text { Behavior }\end{array}$ \\
\hline Vitrinite & $\begin{array}{l}\text { Vitrinite } \\
\text { Pseudovitrinite }\end{array}$ & $\begin{array}{l}\text { Woody tissues, } \\
\text { bark, leaves }\end{array}$ & $\begin{array}{l}\text { Intermediate hydrogen } \\
\text { content and volatiles }\end{array}$ & Reactive \\
\hline Exinite & $\begin{array}{l}\text { Resinite } \\
\text { Exinite }\end{array}$ & $\begin{array}{l}\text { Resins } \\
\text { Spores, cuticles }\end{array}$ & $\begin{array}{l}\text { High hydrogen content } \\
\text { and volatiles }\end{array}$ & Reactive \\
\hline Inertinite & $\begin{array}{l}\text { Semi-fusinite } \\
\text { Semi-macrinite } \\
\text { Fusinite } \\
\text { Macrinite } \\
\text { Micrinite } \\
\text { Sclerotinite }\end{array}$ & $\begin{array}{l}\text { Strongly altered } \\
\text { and degraded } \\
\text { plant material } \\
\text { Fungal remains }\end{array}$ & $\begin{array}{l}\text { Low hydrogen content } \\
\text { and volatiles }\end{array}$ & $\begin{array}{l}\text { General1y } \\
\text { inert }\end{array}$ \\
\hline
\end{tabular}




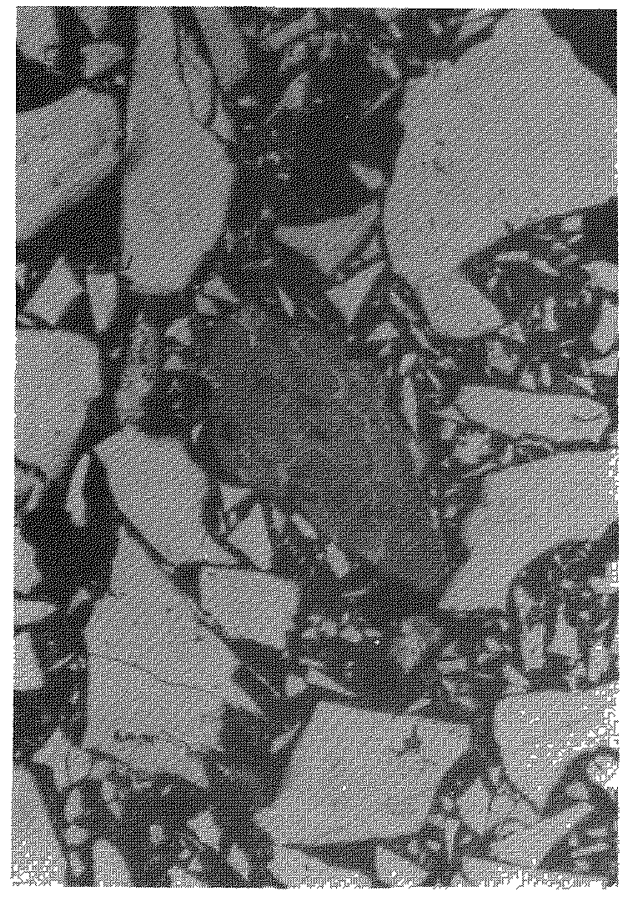

a

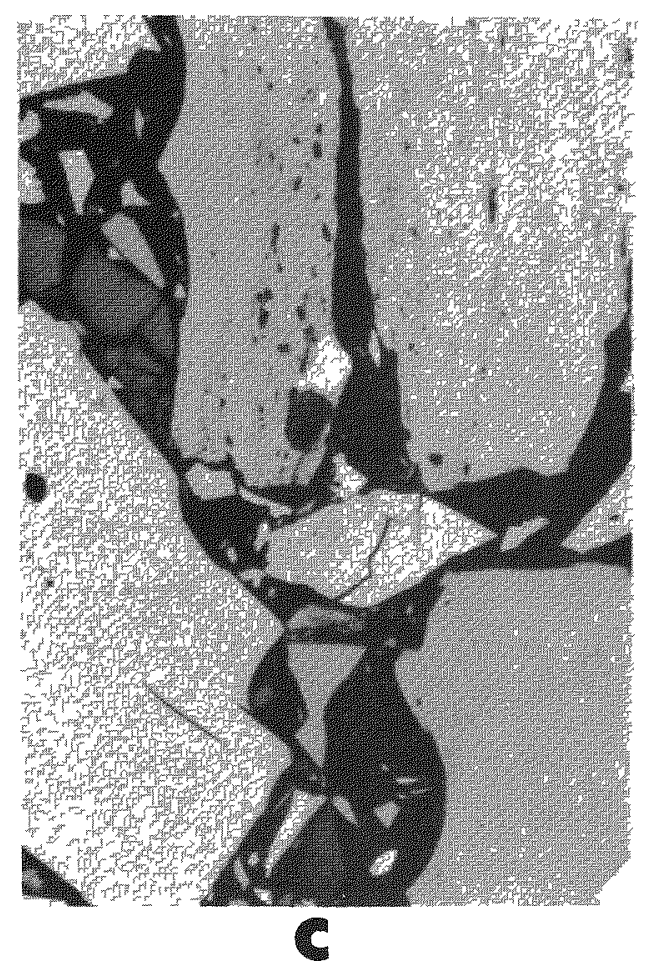

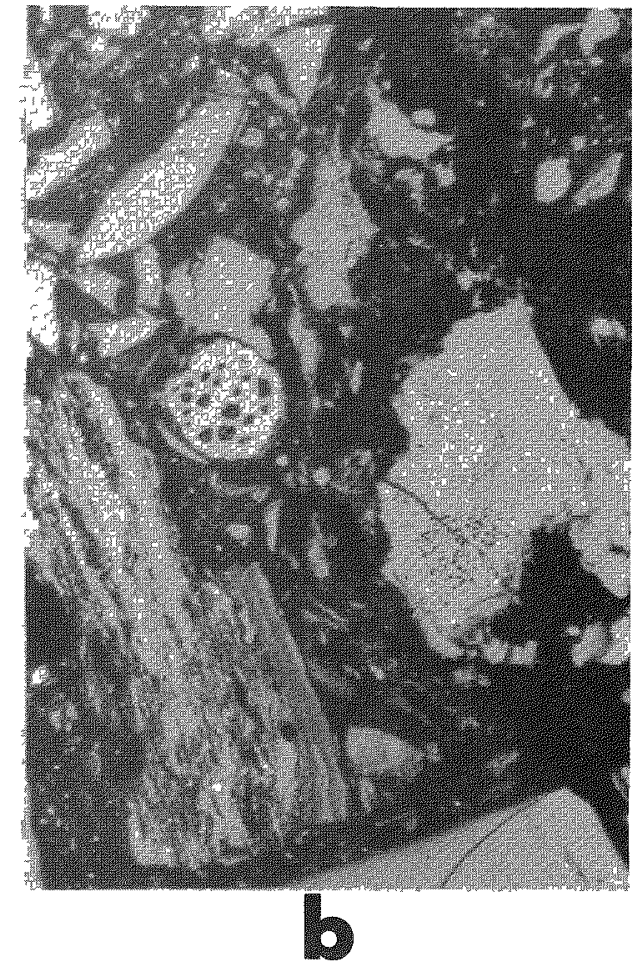

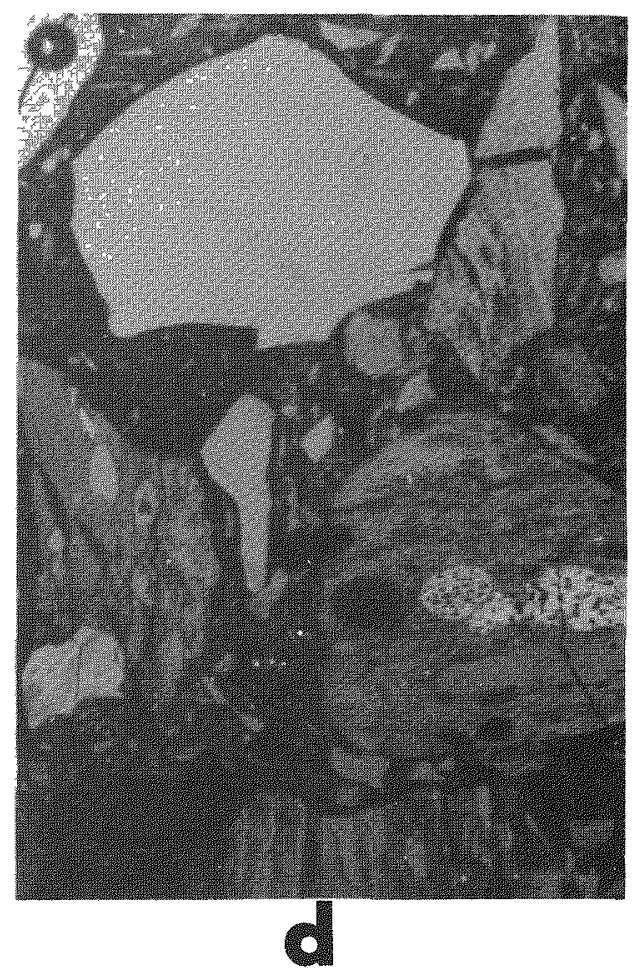

Figure 48. Photomicrographs of coal macerals. (a) Vitrinite (bright) with resinite (X200). (b) Sclerotinite (left center) with semi-fusinite, vitrinite, exinite, and pyrite (upper right) (X200). (c) Vitrinite with exinite and semi-fusinite $\left(\times_{400)}\right.$. (d) Vitrinite with pseudovitrinite, sclerotinite, semi-fusinite, semi-macrinite, and micrinite (X200). 


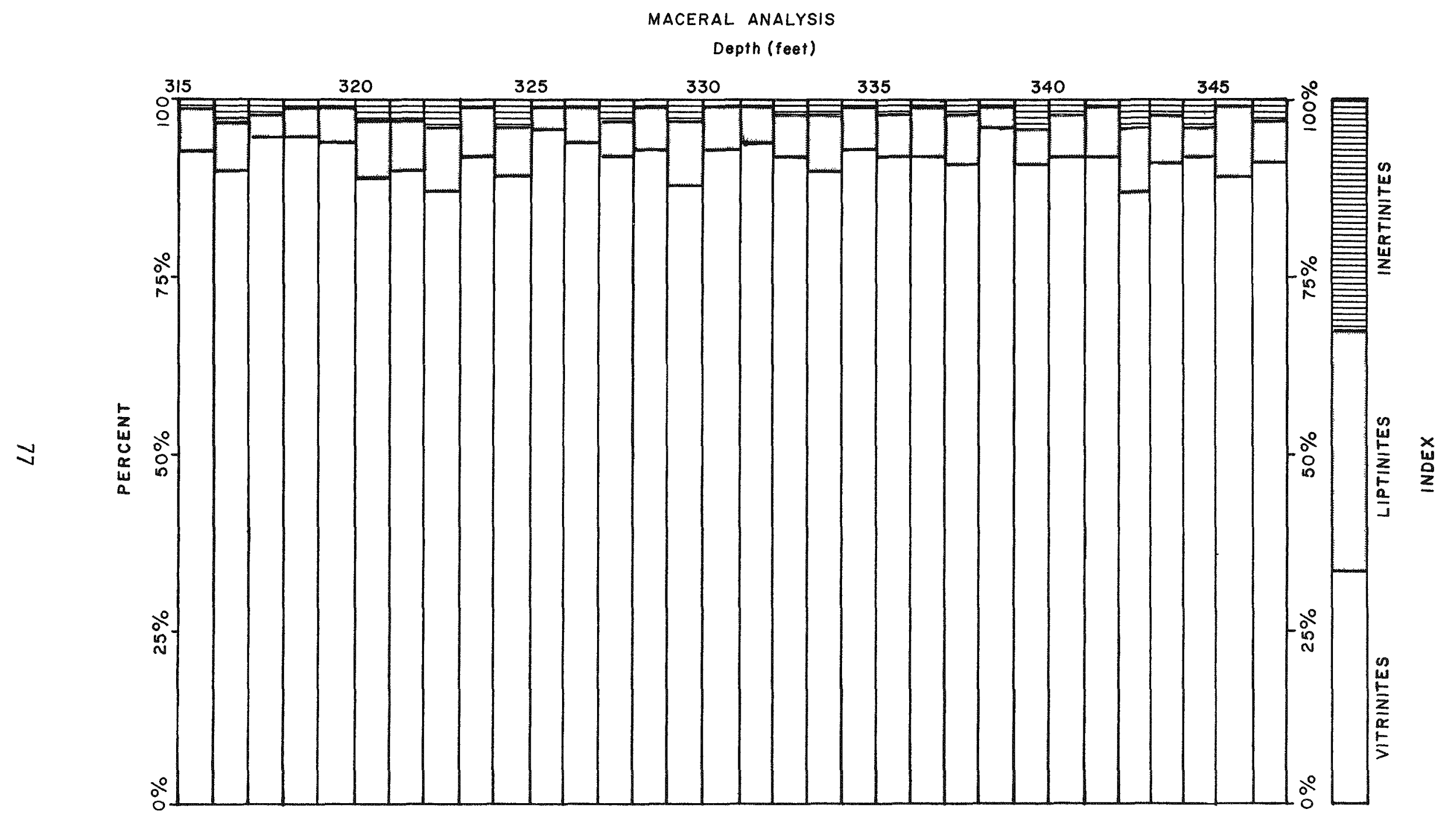

Figure 49. Maceral analysis profile of $\mathrm{CH}-133$, Hanna UCG site. 


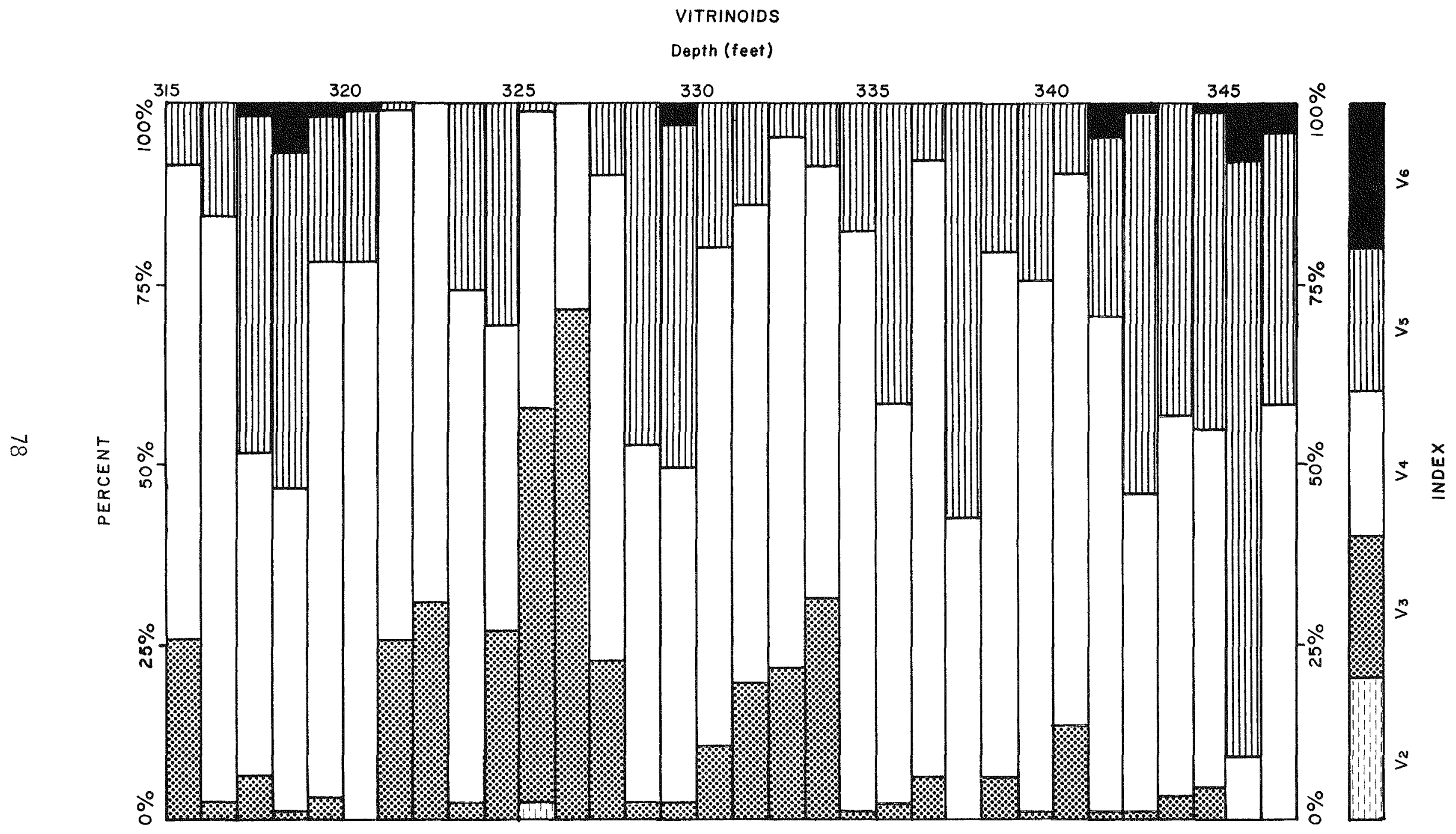

Figure 50. Distribution of vitrinoid types of $\mathrm{CH}-133$, Hanna UCG site. 
Table 11. Maceral analysis (mineral-matter free basis) from the Hanna UCG site.

\begin{tabular}{|c|c|c|c|}
\hline MACERAL GROUP & VOLUME $\%$ & MACERAL & VOLUME \% \\
\hline Vitrinite & 91.8 & $\begin{array}{l}\text { Vitrinite } \\
\text { Pseudovitrinite }\end{array}$ & $\begin{array}{r}90.3 \\
1.5\end{array}$ \\
\hline Exinite & 6.1 & $\begin{array}{l}\text { Exinite } \\
\text { Resinite }\end{array}$ & $\begin{array}{l}5.5 \\
0.6\end{array}$ \\
\hline Inertinite & 2.1 & $\begin{array}{l}\text { Semi-Fusinite } \\
\text { Semi-Macrinite } \\
\text { Fusinite } \\
\text { Macrinite } \\
\text { Micrinite } \\
\text { Sclerotinite }\end{array}$ & $\begin{array}{l}1.0 \\
0.1 \\
0.3 \\
0.1 \\
0.5 \\
0.1\end{array}$ \\
\hline
\end{tabular}

Mean-Maximum Vitrinite Reflectance

Reflectance is the amount of light that is reflected from a surface and expressed as a ratio or percentage of the amount of incident light. Reflectance studies on coal macerals are carried out under standardized conditions and are correlated with the reflectance of glass or synthetic standards. Vitrinite reflectance is determined because the vitrinites are the most abundant macerals in coal, and vitrinites also exhibit a wide range of reflectance in the coalification series. Maximum vitrinite reflectance is measured on a polished surface of a vitrinite maceral using a polarized light microscope and an oil immersion lens. After the vitrinite grain is centered, the circular stage of the microscope is rotated slawly for $360^{\circ}$ and the maximum reflectance (Rmax) is recorded. The average of at least one hundred readings is called the mean-maximum reflectance. The average mean-maximum vitrinite reflectance for 104 samples at the Hanna UCG site was 0.47 .

Rank

The process that alters peat into coal is called coalification. Rank is a classification of the degree of coalification, or progressive alteration from lignite to anthracite coal. In the United States, coals are classified into various ranks in accordance with an ASTM standard. Fixed carbon and calorific values are the two basic parameters used for this classification (Table 12). High-rank coals are classified according to fixed carbon or volatile matter content on a dry, mineralmatter-free basis. Low rank coals are classified according to calorific value on a moist, mineral-matter-free basis. Some coal ranks are also differentiated according to their agglomerating (caking) properties. 


\begin{tabular}{|c|c|c|c|c|c|c|c|}
\hline \multirow[b]{2}{*}{ Group } & \multicolumn{2}{|c|}{$\begin{array}{c}\text { Fixed carbon } \\
\text { limits }(\%) \\
\text { (dry, mineral- } \\
\text { matter-free } \\
\text { basis) }\end{array}$} & \multicolumn{2}{|c|}{$\begin{array}{c}\text { Volatile matter } \\
\text { limits (\%) } \\
\text { (dry, mineral- } \\
\text { matter-free } \\
\text { basis) }\end{array}$} & \multicolumn{2}{|c|}{$\begin{array}{l}\text { Calorific value limits } \\
\text { (Btu/lb) (moist } \\
\text { mineral-matter- } \\
\text { free basis) }\end{array}$} & \multirow[b]{2}{*}{ Agglomerating character } \\
\hline & $\$$ & $<$ & $>$ & $\geqslant$ & $\geqslant$ & $<$ & \\
\hline \multicolumn{8}{|l|}{ 1. Anthracitic } \\
\hline 1. Meta-anthracite & 98 & - & - & 2 & - & - & \multirow{3}{*}{ nonagglomerating } \\
\hline 2. Anthracite & 92 & 98 & 2 & 8 & - & - & \\
\hline 3. Semianthracite & 86 & 92 & 8 & 14 & - & - & \\
\hline \multicolumn{8}{|l|}{ II. Bituminous } \\
\hline 1. Low volatile bituminous coal & 78 & 86 & 14 & 22 & - & - & \multirow{5}{*}{ commonly agglomerating } \\
\hline 2. Medium volatile bitumin ous coal & 69 & 78 & 22 & 31 & - & - & \\
\hline 3. High volatile $A$ bituminous coal & - & 69 & 31 & - & 14,000 & - & \\
\hline 4. High volatile $B$ bituminous coal & - & - & - & - & 13,000 & 14,000 & \\
\hline 5. High volatile $\mathrm{C}$ bituminous coal & - & - & - & - & 11,500 & $\begin{array}{l}13,000 \\
11500\end{array}$ & \\
\hline \multicolumn{8}{|l|}{ III. Subbituminous } \\
\hline 1. Subbitumin ous A coal & - & - & - & - & 10,500 & 11,500 & \multirow{5}{*}{ nonagglomerating } \\
\hline 2. Subbituminous B coal & - & - & - & - & 9,500 & 10,500 & \\
\hline 3. Subbituminous $\mathrm{C}$ coal & - & - & - & - & 8,300 & 9,500 & \\
\hline IV. Lignitic & - & _ & - & _ & $630 n$ & 8300 & \\
\hline $\begin{array}{l}\text { 1. Lignite A } \\
\text { 2. Lignite B }\end{array}$ & $\overline{-}$ & - & - & - & - & 6,300 & \\
\hline
\end{tabular}

Table 12. Classification of coals by rank. 
In order to classify coal using the ASTM system it is necessary to carry out a proximate analysis (moisture, ash, volatile matter, fixed carbon) and determine calorific value. The rank classification for 137 coal samples from the Hanna No. 1 coal seam is shown in Figure 51 . A majority of the samples fall into the High Volatile $C$ Bituminous rank; however, a number of samples fall into the subbituminous ranks.

There is a correlation between high ash content and rank using coal samples from the Hanna site. The higher the ash content, the lower the rank. Figure 52 shows percent ash content calculated for three sample categories that were obtained from the Hanna No. 1 coal seam: carbonaceous shale, subbituminous coal, and bituminous coal. Rank was not calculated on the carbonaceous shale samples (greater than 50 percent ash content by weight). The rank calculated on coal samples (less than 50 percent ash content by weight) fell into two coal classes, subbituminous coal and bituminous coal. Thirty-three carbonaceous shale samples had a mean of 63.95 percent ash content. Twenty-three subbituminous coal samples had a mean of 34.81 percent ash content. One hundred and fourteen High Volatile C Bituminous samples had a mean of 18.81 percent. Distribution of ash percent for cores I-76, II-4, and III-2 is shown in Figure 53. Those footages in black have ash percentages of less than 12 percent. This figure shows that ash content is extreme ly variable through the Hanna No. 1 coal bed with values as low as 4 percent and as high as 79 percent. It appears that the rank calculations for high ash content samples are inaccurate for determination of coal rank on the Hanna coals.

Measurement of coal rank was also done using mean-maximum vitrinite reflectance information. The degree of coal metamorphism has a linear relationship to the reflectance of vitrinite in coal. The higher the vitrinite reflectance, the higher the rank of the coal. Davis (1978) (Table 13) has related maximum vitrinite reflectance directly to the ASTM coal rank classification system. Using the maximum reflectance categories from Table 13, the rank of the coal from the Hanna gasification site was calculated and a histogram of the sample data is shown in Figure 54. The calculation of rank using vitrinite reflectance is very similar to the classification results obtained by using the ASTM method. Sixty-four percent of all the coal samples fell into the High Volatile C Bituminous rank.

Table 13. Classification of coals by rank using maximum reflectance percent.

\section{Rank}

Subbituminous

High Volatile Bituminous $C$ High Volatile Bituminous $B$

High Volatile Bituminous $A$

Medium Volatile Bituminous

Low Volatile Bituminous

Semianthracite

Anthracite
\% Maximum Reflectance

$\begin{aligned} & <0.47 \\ 0.47 & -0.57 \\ 0.57 & -0.71 \\ 0.71 & -1.10 \\ 1.10 & -1.50 \\ 1.50 & -2.05 \\ 2.05 & -3.00 \\ & >3.00\end{aligned}$




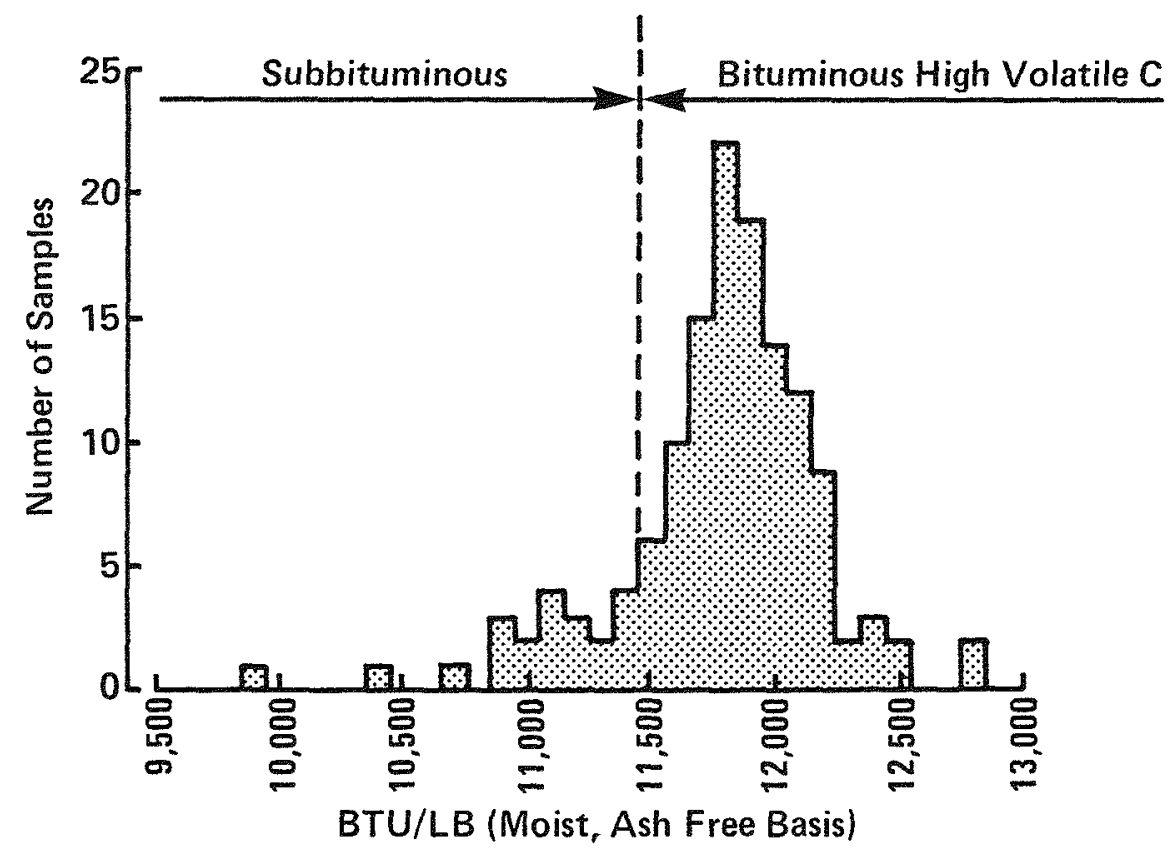

Figure 51. Classification of coal from the Hanna No. 1 coal seam using ASTM methods. 


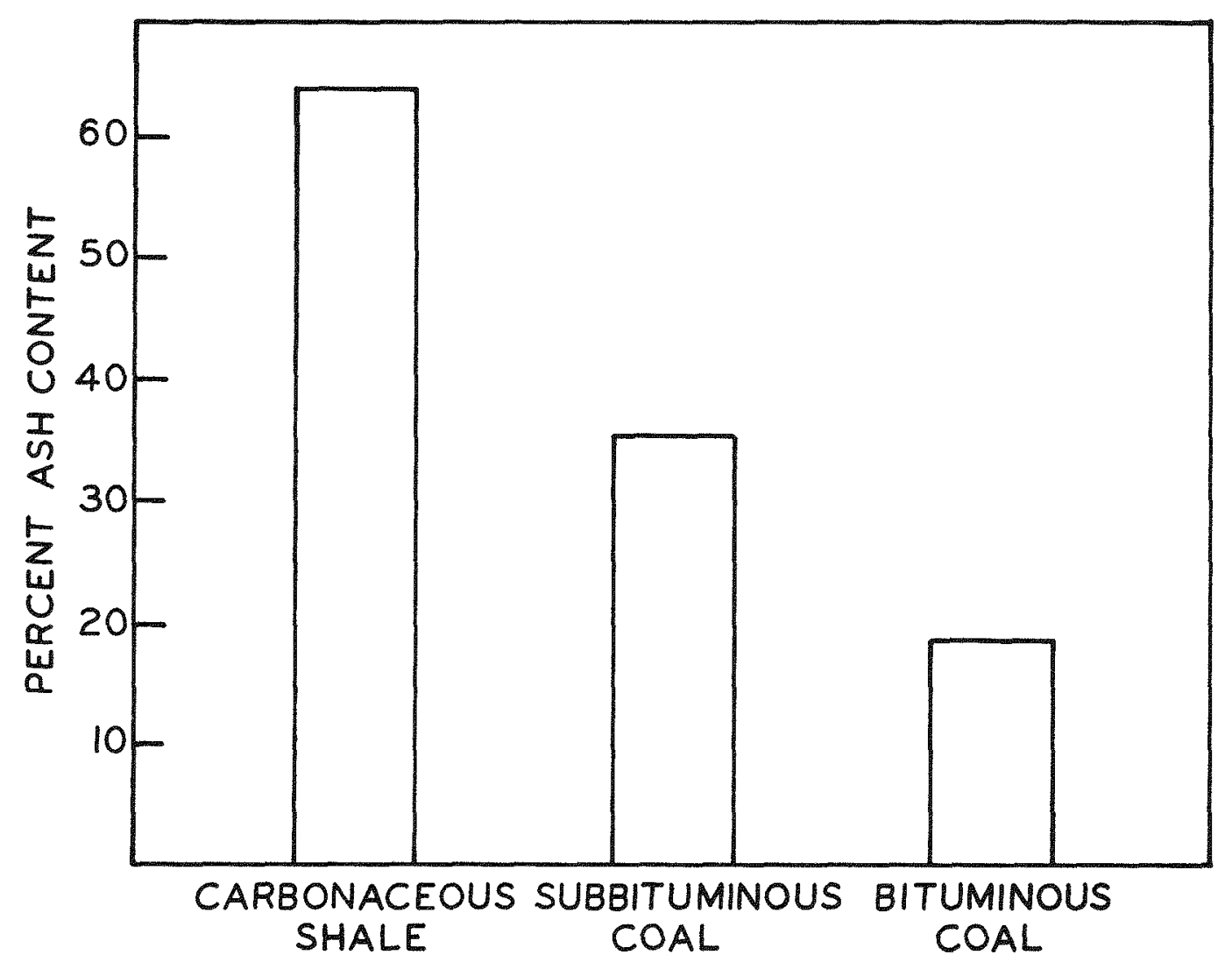

Figure 52. Percent ash content in carbonaceous shate, subbituminous coal, and bituminous coal from the Hanna No. 1 coal seam. 
PERCENT ASH (MOISTURE-FREE) IN COAL CORES
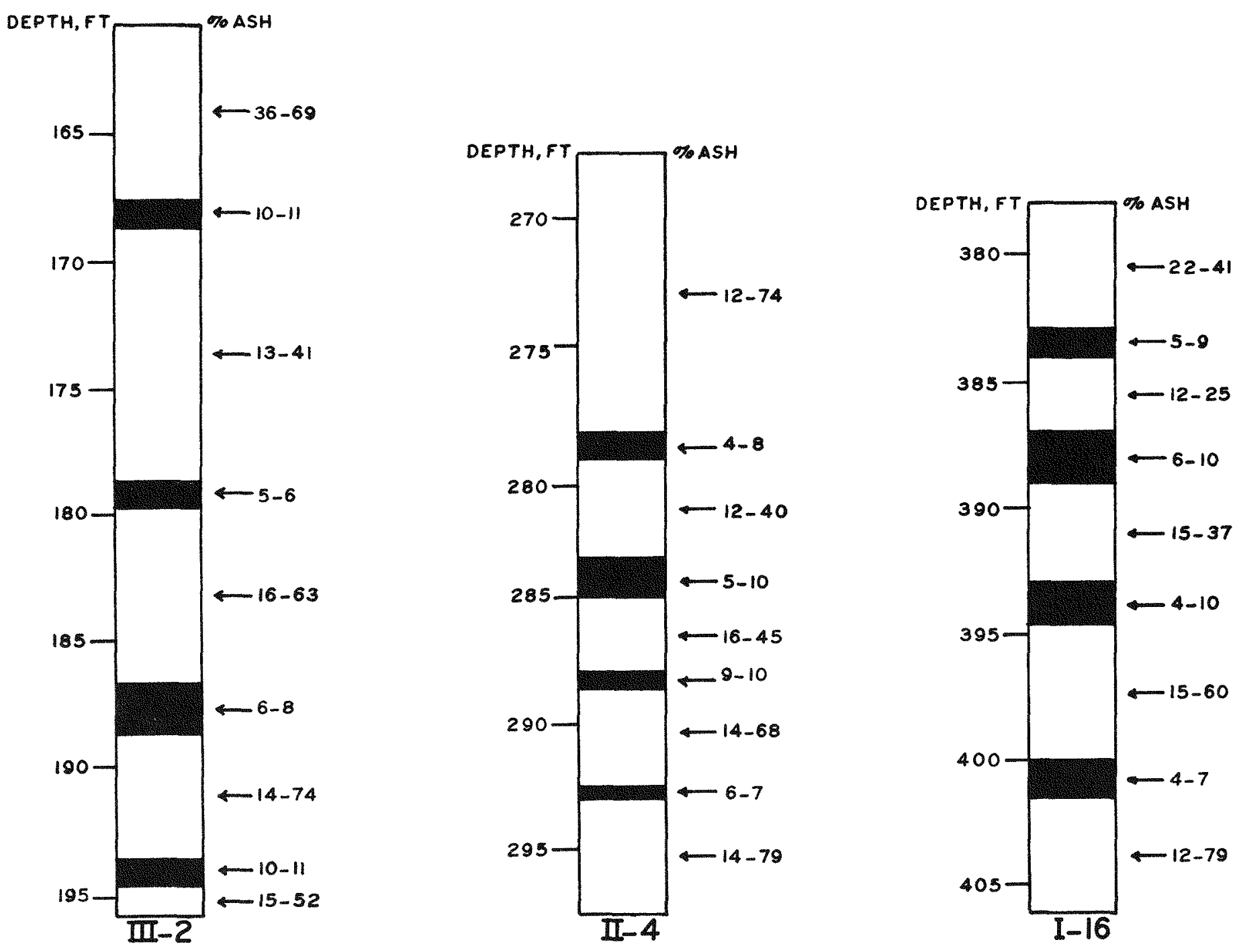

Figure 53. Distribution of ash percentage in the Hanna No. 1 seam for three coreholes from the Hanna UCG site. 


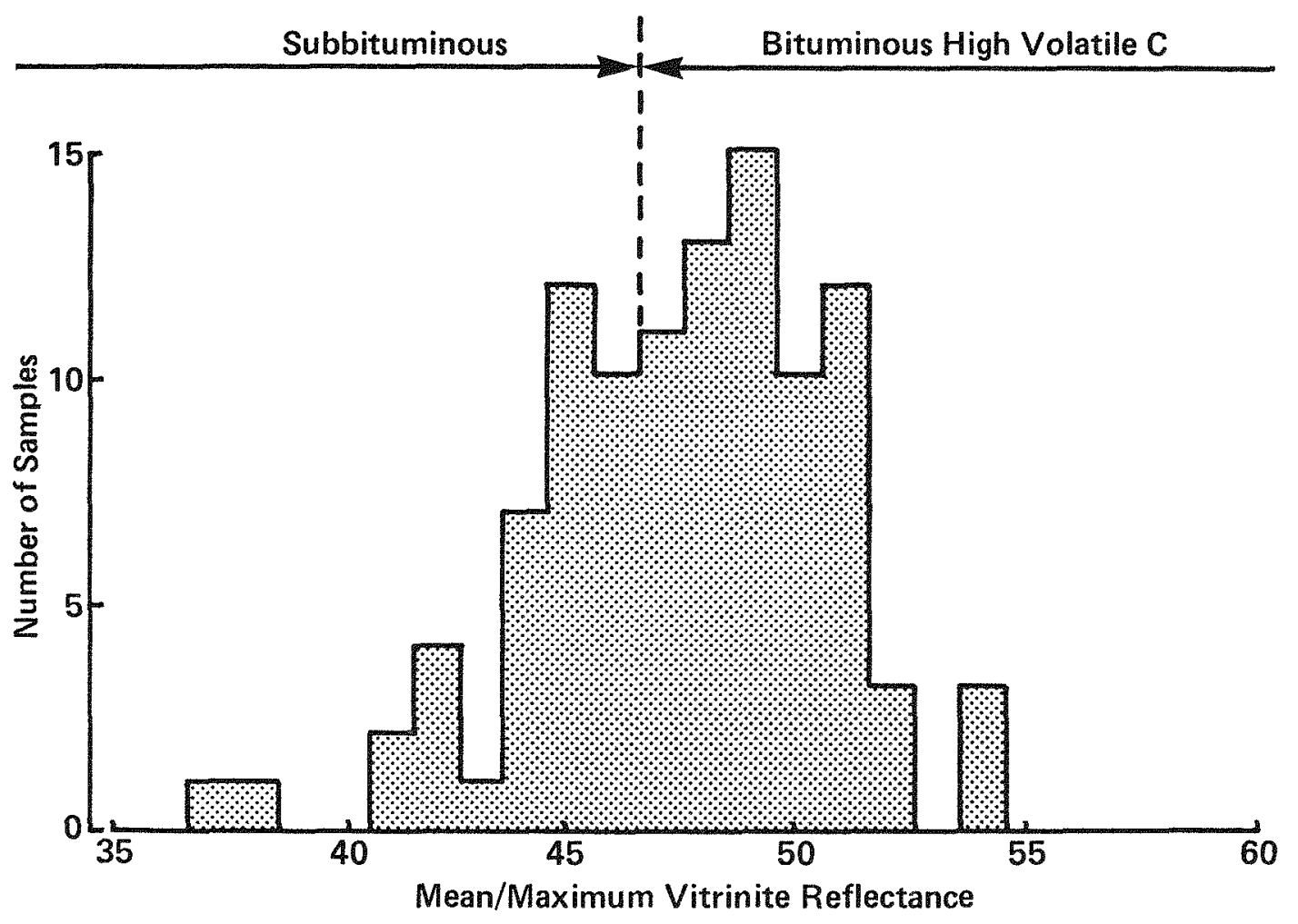

Figure 54. Classification of coal from the Hanna No. 1 coal seam using mean-maximum vitrinite reflectance. 


\title{
GEOCHEMISTRY
}

\author{
Semi-Quantitative Spectrographic Analysis
}

General

Samples from cores taken at the Hanna UCG site were tested using the semi-quantitative spectrographic analys is technique. Six-hundred and twenty-eight samples from coreholes $\mathrm{CH}-131, \mathrm{CH}-132, \mathrm{CH}-133$, and $\mathrm{CH}-$ 134 were evaluated to establish baseline values (not heat altered) for the overburden units in the area. The results are shown in Tables 14 through 17. Values were averaged for each local stratigraphic unit and for the total overburden in each corehole. Coreholes 2HP-170 and 2HP171 were also included for the baseline calculations of the Hanna No. 1 coal (Table 18). An overall site average was calculated for all of the units present (Table 19). Several correlations by element were done with this data: 1) site average coal to site average total overburden; 2) site average stratigraphic unit to site average stratigraphic unit;

3) coal bed correlated hole to hole; 4) local stratigraphic units correlated hole to hole; 5) local stratigraphic unit to local stratigraphic unit within each hole; and 6) coal bed to total overburden within each hole.

\section{Correlations}

\section{Average Coal to Average Overburden}

The average element concentrations in the coal bed when correlated with corresponding values for the overburden shows that with the exception of copper, the concentrations are greater for the overburden. Some elements where the concentrations in the overburden are slightly higher than in the coal are $\mathrm{Cr}, \mathrm{Pb}$, and $\mathrm{V}$ (see Table 19).

\section{Average Stratigraphic Units}

The correlation of average stratigraphic units (see Table 19) is shown in Table 20. This ranks the units from highest to lowest concentration values for each element. The table shows a dominance of Units $A$ and $B$ in the higher concentrations and a dominance of Unit $C$ and the Hanna No. 1 in the lower concentrations. Unit $D$ seems to have dominance in the middle part of the table.

Unit $A$ is present eleven times in the highest column and Unit $B$ is present ten times in this column. Unit $C$ appears only once in this column, for the element barium. Unit $D$ appears twice for the element boron and in a tie with Units $A$ and $B$ for the element beryllium. Unit $A$ also appears seven times in the second column. These seven appearances are for all but one of the eight elements in the highest column that did not have Unit A present. Therefore, eighteen of Unit A's nineteen appearances are in columns 1 and 2 . Twelve of nineteen Unit $B$ appearances are in columns 1 and 2 . 
Table 14. Average semi-quantitative spectrographic analysis of $\mathrm{CH}-131$.

OVERBURDEN UNITS

\begin{tabular}{|c|c|c|c|c|c|c|c|c|c|c|c|c|c|c|c|c|c|c|c|c|}
\hline Unit & $(.05)$ & $(.02)$ & $(.05)$ & $(.002)$ & (10) & (.5) & $(10$ & (20) & (1) & (5) & (10) & (5) & (20) & (5) & (10) & (5) & (10) & (10) & (10) & (10) \\
\hline (\# Samp) & $\mathrm{Fe}^{\%}$ & $\mathrm{Mg} \%$ & $\mathrm{Ca} \%$ & $\mathrm{Ti} \%$ & $\mathrm{Mn}$ & $\mathrm{Ag}$ & B & $\mathrm{Ba}$ & $\mathrm{Be}$ & Co & $\mathrm{Cr}$ & $\mathrm{Cu}$ & $\mathrm{La}$ & $\mathrm{Ni}$ & $\mathrm{Pb}$ & Sc & V & Y & $\mathrm{Zr}$ & $\mathrm{Ga}$ \\
\hline nit $\mathrm{C}(73$ & 1.9 & 1.1 & 0.55 & 0.20 & 633 & $\mathrm{~L}$ & 32 & 870 & 1.2 & 7 & 44 & $\star 7$ & $\star 28$ & 12 & 13 & 8 & 50 & 24 & 262 & 52 \\
\hline Init B 150 & 2.5 & 0.9 & 0.21 & 0.27 & 480 & $\star 0.5$ & 39 & 638 & 1.1 & 9 & 66 & $\star 18$ & $\star 36$ & 28 & 18 & 12 & 87 & 25 & 208 & 68 \\
\hline
\end{tabular}

TOTAL OVERBURDEN

\begin{tabular}{lllllllllllllllllllll}
\hline Units A-D & 2.1 & 1.2 & 0.90 & 0.24 & 583 & $* \mathrm{~L}$ & 40 & 780 & 1.3 & 8 & 54 & $* 15$ & $\star 35$ & 19 & 18 & 11 & 68 & 26 & 233 & 72
\end{tabular}

COAL

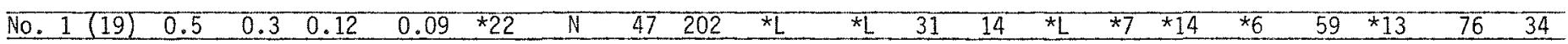

Remarks: $\mathrm{Fe}, \mathrm{Mg}, \mathrm{Ca}$ and $\mathrm{Ti}$ reported in \%; all other elements reported in ppm. Results are in the series $1,1.5,2,3,5,7,10$, etc. Lower 1imits of determination are in parentheses. N=Not detected at limit of detection; $L=$ Detected, but below limit of determination; $L(N)=L$ and $N$ both common in the data averaged; $N(L)=0 n$ ly sporadic $L$ in data. *-In data where number values and letter denotations are both common, $L$ was assigned a value of $\frac{1}{2}$ the detection limit and $N$ was assigned a value of zero. 
Table 15. Average semi-quantitative spectrographic anaiysis of $\mathrm{CH}-132$.

OVERBURDEN UNITS

\begin{tabular}{|c|c|c|c|c|c|c|c|c|c|c|c|c|c|c|c|c|c|c|c|c|}
\hline $\begin{array}{l}\text { Unit } \\
\text { (\# Samp) }\end{array}$ & $\begin{array}{c}(.05) \\
\mathrm{Fe} \%\end{array}$ & $\begin{array}{l}(.02) \\
\mathrm{Mg} \%\end{array}$ & $\begin{array}{l}(.05) \\
\mathrm{Ca} \%\end{array}$ & $\begin{array}{c}(.002) \\
T i \%\end{array}$ & $\begin{array}{l}(10) \\
M n\end{array}$ & $\begin{array}{c}(.5) \\
\dot{A g}\end{array}$ & $\begin{array}{c}(10) \\
B\end{array}$ & $\begin{array}{c}720) \\
\mathrm{Ba}\end{array}$ & $\begin{array}{r}\text { (1) } \\
\mathrm{Be}\end{array}$ & $\begin{array}{l}(5) \\
\text { Co } \\
\end{array}$ & $\begin{array}{l}710) \\
\mathrm{Cr}\end{array}$ & $\begin{array}{l}(5) \\
\mathrm{Cu} \\
\end{array}$ & $\begin{array}{c}(20) \\
\mathrm{La} \\
\end{array}$ & $\begin{array}{l}75 \\
\mathrm{Ni} \\
\end{array}$ & $\begin{array}{c}(10) \\
\mathrm{Pb}\end{array}$ & $\begin{array}{r}75) \\
\text { Sc } \\
\end{array}$ & $\begin{array}{c}(10) \\
V\end{array}$ & $\begin{array}{c}(10) \\
Y\end{array}$ & $\begin{array}{l}(10) \\
\mathrm{Zr}\end{array}$ & $\begin{array}{l}(10) \\
\mathrm{Ga} \\
\end{array}$ \\
\hline Unit D (35) & 2.1 & 1.0 & 0.44 & 0.20 & 544 & $\mathrm{~N}$ & 69 & 749 & 1.4 & 8 & 68 & 19 & 38 & 20 & 21 & 12 & 90 & 23 & 163 & 109 \\
\hline Unit C (108) & 1.9 & 0.8 & 0.57 & 0.17 & 547 & 2.3 & 19 & 1179 & .2 & 7 & 44 & ${ }^{*} 6$ & $\star 41$ & 27 & 15 & 16 & 49 & 20 & 204 & 46 \\
\hline Unit A $(37)$ & 3.0 & 1.7 & 1.01 & 0.38 & 506 & $\star L$ & 90 & 905 & 1.4 & 13 & 76 & 32 & 52 & 32 & 35 & 13 & 119 & 31 & 304 & 151 \\
\hline
\end{tabular}

TOTAL OVERBUROEN

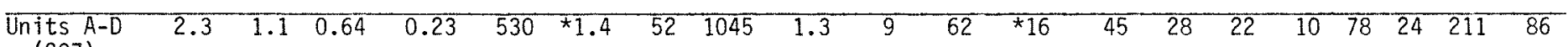

COAL

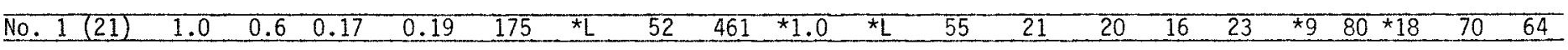

Remarks: $\mathrm{Fe}, \mathrm{Mg}, \mathrm{Ca}$ and $\mathrm{Ti}$ reported in \%; all other elements in ppm. Results are in the series $1,1.5,2,3,5,7,10$, etc. Lower limits of determination are in parentheses. $N=$ Not detected at limit of detection; L=Detected, but below limit of determination. $L(N)=L$ and $N$ both common in the data averaged; $N(L)=0$ nly sporadic $L$ in data.

* In data where number values and letter denotations are both common, $L$ was assigned a value of $\frac{1}{2}$ the detection limit and $\mathrm{N}$ was assigned a value of zero. 
Table 16. Average semi-quantitative spectrographic analys is of $\mathrm{CH}-133$.

OVERBURDEN UNITS

\begin{tabular}{|c|c|c|c|c|c|c|c|c|c|c|c|c|c|c|c|c|c|c|c|c|}
\hline $\begin{array}{l}\text { Unit } \\
\text { (\# Samp) }\end{array}$ & $\begin{array}{l}(.05) \\
\mathrm{Fe}^{2} \%\end{array}$ & $\begin{array}{r}(.02) \\
\mathrm{Mg} \%\end{array}$ & $\begin{array}{r}(.05) \\
\mathrm{Ca} \%\end{array}$ & $\begin{array}{r}(.002) \\
T i \%\end{array}$ & $\begin{array}{c}(10) \\
\mathrm{Mn}\end{array}$ & $\begin{array}{c}(1.5) \\
\mathrm{Ag}\end{array}$ & $\begin{array}{c}(10) \\
B\end{array}$ & $\begin{array}{c}(20) \\
\mathrm{Ba}\end{array}$ & $\begin{array}{l}\text { (1) } \\
\mathrm{Be}\end{array}$ & $\begin{array}{l}\text { (5) } \\
\text { Co }\end{array}$ & $\begin{array}{c}(10) \\
C r\end{array}$ & $\begin{array}{l}\text { (5) } \\
\mathrm{Cu}\end{array}$ & $\begin{array}{c}(20) \\
\mathrm{La}\end{array}$ & $\begin{array}{l}\text { (5) } \\
\mathrm{Ni}\end{array}$ & $\begin{array}{c}(10) \\
\mathrm{Pb}\end{array}$ & $\begin{array}{r}75) \\
\text { SC }\end{array}$ & $\begin{array}{c}(10) \\
V\end{array}$ & $\frac{(10)}{Y}$ & $\begin{array}{l}(10) \\
Z r\end{array}$ & $\begin{array}{c}(10) \\
\mathrm{Ga}\end{array}$ \\
\hline Unit C $(25)$ & 1.4 & 0.3 & 0.30 & 0.14 & 268 & N & 12 & 928 & 1.2 & $\star 9$ & $* 28$ & $\star 7$ & $\star 27$ & $\star 8$ & 22 & 6 & 25 & $\star 13$ & 168 & 21 \\
\hline Unit B (27) & 2.2 & 0.7 & 0.69 & 0.30 & 185 & $\bar{N}$ & 20 & 763 & 1.6 & 13 & 75 & 22 & 57 & 18 & 41 & 13 & 53 & 26 & 174 & 95 \\
\hline
\end{tabular}

TOTAL OVERBURDEN

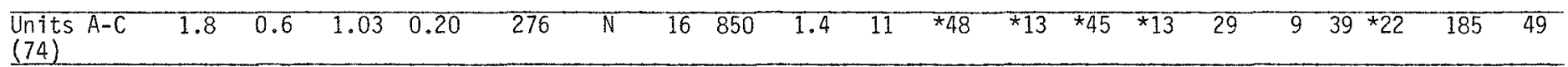

COAL

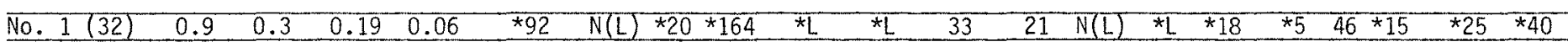

Remarks: $\mathrm{Fe}, \mathrm{Mg}, \mathrm{Ca}$ and $\mathrm{Ti}$ reported in \%; a 11 other elements in ppm. Results are in the series $1,1.5,2,3,5,7,10$, etc. Lower 7 imits of determination are in parentheses. N=Not detected at limit of detection; L=Detected, but below limit of determination. $L(N)=L$ and $N$ both common in the data averaged; $N(L)=0$ nly sporadic $L$ in data.

$*=$ In data where number values and letter denotations are both common, $L$ was assigned a value of $\frac{1}{2}$ the detection Timit and $N$ was assigned a value of zero. 
Table 17. Average semi-quantitative spectrographic analys is of $\mathrm{CH}-134$.

OVERBURDEN UNITS

\begin{tabular}{|c|c|c|c|c|c|c|c|c|c|c|c|c|c|c|c|c|c|c|}
\hline $\begin{array}{l}\text { Unit } \\
\text { (\# Samp) }\end{array}$ & $\begin{array}{c}(.05) \\
\mathrm{Fe} \% \\
\end{array}$ & $\begin{array}{l}(.02) \\
\mathrm{Mg} \%\end{array}$ & $\begin{array}{l}(.05) \\
\mathrm{Ca} \%\end{array}$ & $\begin{array}{c}(.002) \\
T i \%\end{array}$ & $\begin{array}{l}(10) \\
\mathrm{Mn}\end{array}$ & $\begin{array}{l}(.5) \\
\mathrm{Ag}\end{array}$ & $\begin{array}{r}(10) \\
B\end{array}$ & $\begin{array}{c}(20) \\
\mathrm{Ba} \\
\end{array}$ & $\begin{array}{r}(1) \\
\mathrm{Be} \\
\end{array}$ & $\begin{array}{r}(5) \\
\mathrm{CO} \\
\end{array}$ & $\begin{array}{c}(10) \\
\mathrm{Cr}\end{array}$ & $\begin{array}{l}\text { (5) } \\
\mathrm{Cu}\end{array}$ & $\begin{array}{c}(20) \\
\text { La } \\
\end{array}$ & $\begin{array}{l}(5) \\
\mathrm{Ni} \\
\end{array}$ & $\begin{array}{cc}(10) & (5) \\
\mathrm{Pb} \quad \mathrm{SC} \\
\end{array}$ & $\begin{array}{c}(10) \\
V\end{array}$ & $\begin{array}{c}(10) \\
Y\end{array}$ & $\begin{array}{c}(10)(10) \\
\mathrm{Zr} \quad \mathrm{Ga}\end{array}$ \\
\hline $\begin{array}{l}\text { Unit B } \\
\text { Unit A }\end{array}$ & $\frac{4.7}{2.5}$ & $\frac{1.0}{1.5}$ & $\begin{array}{l}5.36 \\
1.00\end{array}$ & $\begin{array}{r}0.29 \\
-0.26 \\
\end{array}$ & $\frac{731}{681}$ & $\begin{array}{l}L(N) \\
L(N)\end{array}$ & $\frac{73}{71}$ & $\frac{718}{700}$ & $\frac{1.5}{1.5}$ & $\frac{10}{13}$ & $\frac{78}{68}$ & $\frac{26}{25}$ & $\frac{45}{48}$ & $\frac{30}{35}$ & $\begin{array}{rr}27 & 13 \\
28 & 14 \\
\end{array}$ & 90 & $\frac{30}{34}$ & $190 \quad 139$ \\
\hline
\end{tabular}

TOTAL OVERBURDEN

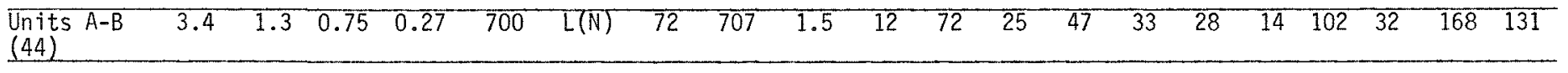

COAL

\begin{tabular}{lllllllllllllllllllllll}
\hline No. $1(32)$ & 1.2 & 0.4 & 0.31 & 0.14 & 147 & $* L(N)$ & 42 & 397 & $* 1.1$ & $* L$ & 51 & 25 & $* L$ & $\star 9$ & 23 & $\star 6$ & 62 & $\star 22$ & 80 & 65 \\
\hline
\end{tabular}

Remarks: $\mathrm{Fe}, \mathrm{Mg}, \mathrm{Ca}$ and $\mathrm{Ti}$ reported in \%; all other elements in ppm. Results are in the series 1, 1.5, 2, 3, 5, 7, 10, etc. Lower limits of determination are in parentheses. $N=$ Not detected at limit of detection; L=Detected, but below limit of determination. $L(N)=L$ and $N$ both common in the data averaged; $N(L)=0$ nly sporadic $L$ in data. $*=$ In data where number values and letter detonations are both common, $L$ was assigned a value of $\frac{1}{2}$ the detection limit and $\mathrm{N}$ was assigned a value of zero. 
Table 18. Average semi-quantitative snectrographic analysis of $2 H P-170$ and $2 H P-171$.

2HP-170: COAL

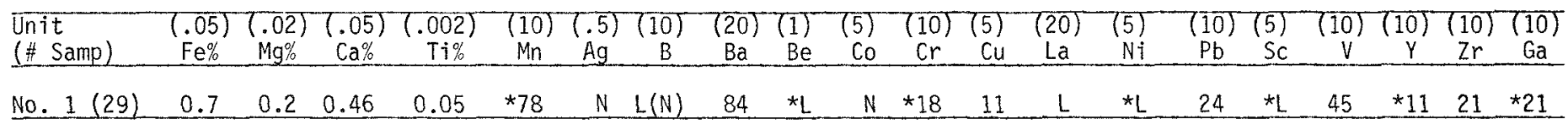

2HP-171: COAL

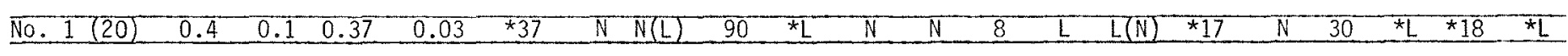

Remarks: $\mathrm{Fe}, \mathrm{Mg}, \mathrm{Ca}$ and $\mathrm{Ti}$ reported in \%; all other elements in ppm. Results are in the series 1, 1.5, 2, 3, 5, 7, 10, etc. Lower limits of determination are in parentheses. $N=$ Not detected at limit of detection; L=Detected,

but below limit of determination. $L(N)=L$ and $N$ both common in the data averaged; $N(L)=0$ nly sporadic $L$ in data. $*=$ In data where number values and letter denotations are both common, $L$ was assigned a value of $\frac{1}{2}$ the detection limit and $N$ was assigned a value of zero. 
Table 19. Average baseline values for the Hanna UCG site.

AVERAGE OVERBURDEN UNITS

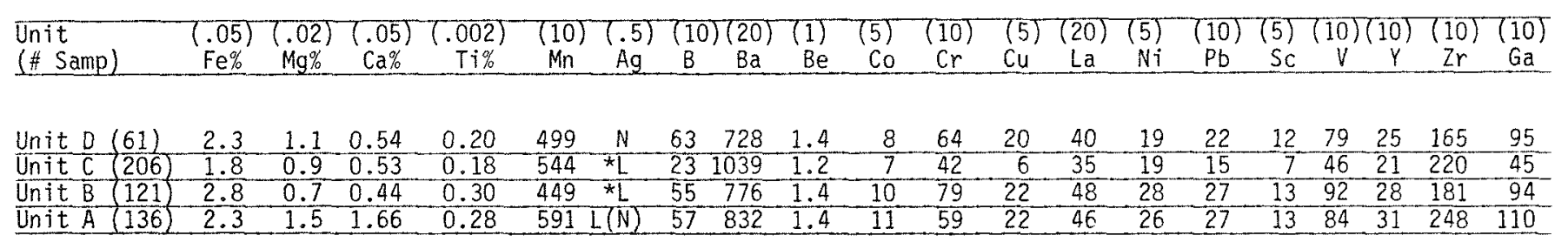

TOTAL AVERAGE OVERBURDEN

\begin{tabular}{l}
$\begin{array}{l}\text { Units } A-D \\
(524)\end{array}$ \\
\hline
\end{tabular}

AVERAGE COAL

$\begin{array}{llllllllllllllllllll} & \text { No. } 1](153) & 0.8 & 0.4 & 0.28 & 0.09 & 96 * L(N) & * 27 & 234 & * L & * L(N) & * 33 & 17 & * L & * 8 & 20 & * 5 & 53 * 14 & 47 & * L\end{array}$

Remarks: Unit $\mathrm{D}$ - Average of $\mathrm{CH}-131$ and $\mathrm{CH}-132$.

Unit C - Average of $\mathrm{CH}-131, \mathrm{CH}-132$, and $\mathrm{CH}-133$.

Unit $\mathrm{B}$ - Average of $\mathrm{CH}-131, \mathrm{CH}-132, \mathrm{CH}-133$, and $\mathrm{CH}-134$.

Unit A - Average of $\mathrm{CH}-131, \mathrm{CH}-132, \mathrm{CH}-133$, and $\mathrm{CH}-134$.

Hanna No. 1 - Average of $\mathrm{CH}-131, \mathrm{CH}-132, \mathrm{CH}-133, \mathrm{CH}-134,2 \mathrm{HP}-170$, and $2 \mathrm{HP}-171$. 
Table 20. Average stratigraphic unit correlation.

\begin{tabular}{|c|c|c|c|c|c|}
\hline ELEMENT & HIGHEST & 2 & 3 & 4 & LEAST \\
\hline $\mathrm{Fe}$ & B & A & $D$ & C & No. 1 \\
\hline $\mathrm{Mg}$ & A & $D$ & c & B & No. 1 \\
\hline $\mathrm{Ca}$ & A & D & $c$ & B & No. 1 \\
\hline$T i$ & B & A & D & C & No. 1 \\
\hline Mn & A & C & D & B & No. 1 \\
\hline B & D & A & B & No. 1 & C \\
\hline $\mathrm{Ba}$ & C & A & B & D & No. 1 \\
\hline $\mathrm{Be}$ & $A, B, D$ & -- & -- & $c$ & No. 1 \\
\hline Co & A & B & D & c & No. 1 \\
\hline $\mathrm{Cr}$ & B & D & A & No. 1 & C \\
\hline $\mathrm{Cu}$ & $A, B$ & -- & No. 1 & D & C \\
\hline La & B & A & $D$ & C & No. 1 \\
\hline $\mathrm{Ni}$ & B & A & $C, D$ & -- & No. 1 \\
\hline $\mathrm{Pb}$ & $A, B$ & -- & D & No. 1 & $C$ \\
\hline Sc & $A, B$ & -- & D & $C$ & No. 1 \\
\hline V & B & A & $D$ & No. 1 & C \\
\hline Y & A & B & $D$ & C & No. 1 \\
\hline $\mathrm{Zr}$ & A & $c$ & B & D & No. 1 \\
\hline Ga & A & $D$ & B & No. 1 & C \\
\hline
\end{tabular}


Unit D's dominance in the middle column is also shown by a similar evaluation. Seventeen of Unit D's nineteen appearances are in the middle columns 2,3 and 4 , with 10 in column 3 . Thirteen of nineteen Unit $C$ appearances are in columns 4 and 5 (least) and, as expected, eighteen of nineteen appearances of the Hanna No. 1 are in columns 4 and 5 with 13 in column 5 , with thirteen in column 5 or the least column.

This correlation shows a definite trend for the average values of the local stratigraphic units in the Hanna UCG area. The highest concentrations are generally found in Unit $A$ and Unit $B$ respectively. The moderate values are found in Unit $D$ with the lowest values found in Unit $C$ and in the Hanna No. 1 coal seam. This is expected for the coal as it was previously shown in the coal to overburden correlation. The trend in the overburden units, Units $A, B, C$ and $D$, are probably representative of sandstone content in the unit. The unit with the highest sandstone percentage would have the lowest values due to a silicon dilution effect. Conversely, the unit with the lowest sandstone percentage (or highest siltstone/shale percentage) would have the highest values. This suggests that Unit $C$ has the highest sandstone percentage, followed by Unit $D$, Unit $B$ and finally Unit $A$. The depositional environments and core analysis previously discussed in this paper support this hypothesis.

\section{Hanna No. 1 - Hole to Hole}

The correlations for the Hanna No. 1 coal bed from hole to hole is shown in Table 21. An evaluation of this table shows a strong dominance of $\mathrm{CH}-132$ and $\mathrm{CH}-134$ in the higher values columns ( 1 and 2). $\mathrm{CH}-132$ and $\mathrm{CH}-134$ both have sixteen of eighteen appearances in these two columns. $\mathrm{CH}-132$ has ten in the highest column and $\mathrm{CH}-134$ has six. Also note that CH-132 and $\mathrm{CH}-134$ do not appear in the least column. In the middle of the spectrum, $\mathrm{CH}-133$ has fifteen of eighteen appearances in the middle columns ( 3 and 4 ) while $\mathrm{CH}-131$ has nine of eighteen. $2 \mathrm{HP}-170$ and $2 \mathrm{HP}$ 171 dominate the lower concentration columns ( 5 and 6 ) with twe lve of eighteen appearances in these columns for $2 \mathrm{HP}-170$ and sixteen of eighteen appearances for $2 \mathrm{HP}-171$. The concentration trend for the Hanna No. 1 coal bed is shown diagrammatically in Figure 55.

The explanation for this strong trend may be that the arrows on Figure 55 point toward the margins of the poorly drained overbank swamp in which the Hanna No. 1 coal bed was deposited. More coal impurities would be expected as the swamp margins were approached. The ash content of the coal should increase in the direction of the arrows on Figure 55. This hypothesis is partialiy supported by the ash percent isogram shown in Plate VII (data taken from Table 5). A further comparison of element concentrations versus ash percent can be made by comparing the profiles for $\mathrm{CH}-133$ contained in Appendix $\mathrm{B}$. 
Table 21. Hanna No. 1 - hole to hole correlation.

\begin{tabular}{|c|c|c|c|c|c|c|}
\hline ELEMENT & HIGHEST & 2 & 3 & 4 & 5 & LEAST \\
\hline $\mathrm{Fe}$ & 134 & 132 & 133 & 170 & 131 & 171 \\
\hline $\mathrm{Mg}$ & 132 & 134 & 131,133 & -- & 170 & 171 \\
\hline $\mathrm{Ca}$ & 170 & 171 & 134 & 133 & 132 & 131 \\
\hline $\mathrm{Ti}$ & 132 & 134 & 131 & 133 & 170 & 171 \\
\hline$M n$ & 132 & 134 & 133 & 170 & 171 & 131 \\
\hline B & 132 & 131 & 134 & 133 & 170 & 171 \\
\hline $\mathrm{Ba}$ & 132 & 134 & 131 & 133 & 171 & 170 \\
\hline $\mathrm{Be}$ & 134 & 132 & $-\cdots$ & -- & --- & $33,170,171$ \\
\hline $\mathrm{Cr}$ & 132 & 134 & 133 & 131 & 170 & 171 \\
\hline $\mathrm{Cu}$ & 134 & 132,133 & -- & 131 & 170 & 171 \\
\hline La & 132 & 131,134 & -- & 170,171 & -- & 133 \\
\hline $\mathrm{Ni}$ & 132 & 134 & 131 & 133,170 & -- & 171 \\
\hline $\mathrm{Pb}$ & 170 & 132,134 & -.. & 133 & 171 & 131 \\
\hline Sc & 132 & 131,134 & -- & 133 & 170 & 171 \\
\hline V & 132 & 134 & 131 & 133 & 170 & 171 \\
\hline Y & 134 & 132 & 133 & 131 & 170 & 171 \\
\hline $\mathrm{Zr}$ & 134 & 131 & 132 & 133 & 170 & 171 \\
\hline $\mathrm{Ga}$ & 134 & 132 & 133 & 131 & 170 & 171 \\
\hline
\end{tabular}




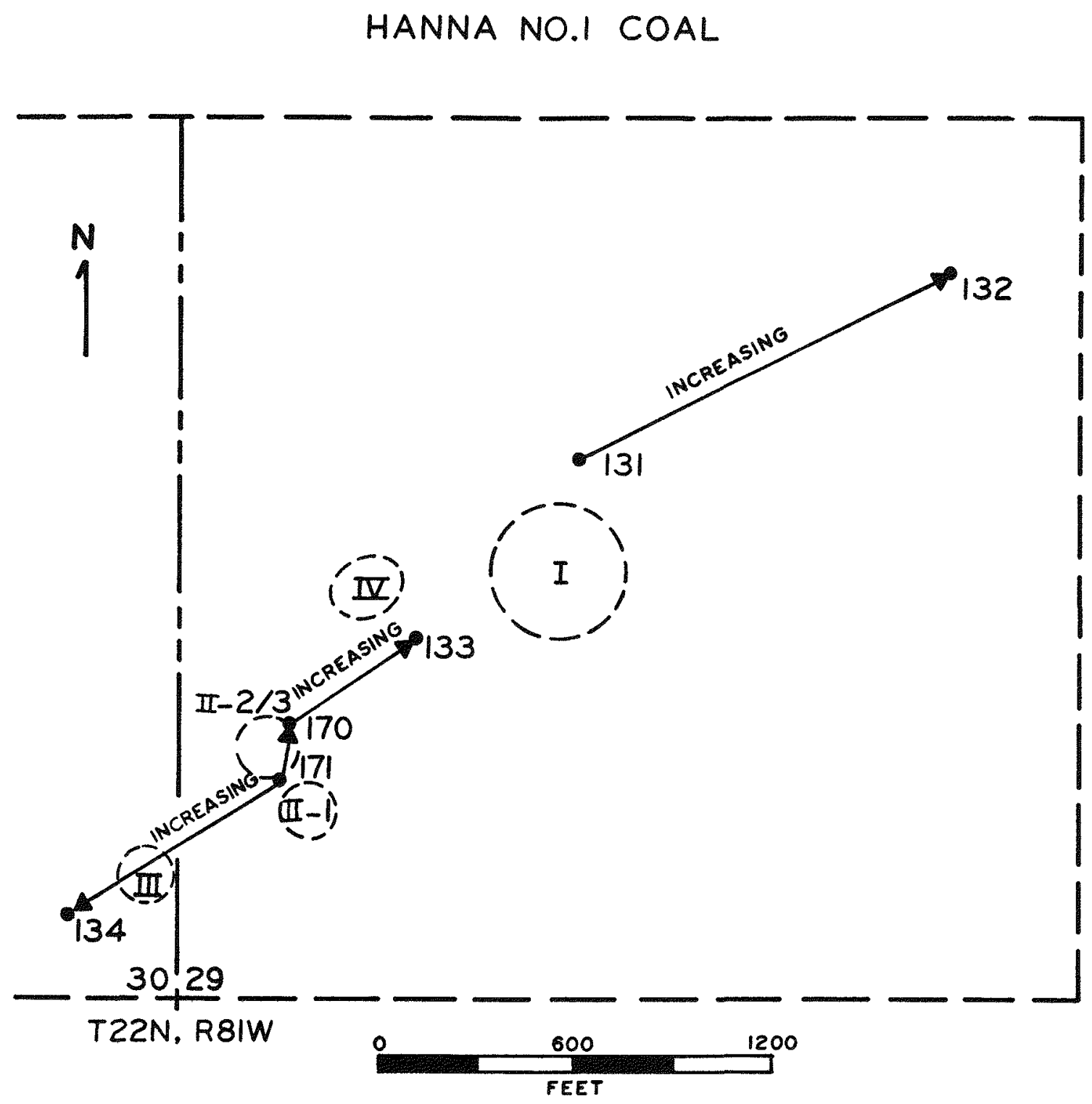

Figure 55. Diagrammatic representation of element concentration trends in the Hanna No. 1 coal seam, Hanna UCG site. 


\section{Local Overburden Units - Hole to Hole}

Onty the more dominant elements $\mathrm{Fe}, \mathrm{Mg}, \mathrm{Ca}, \mathrm{Mn}, \mathrm{B}$ and $\mathrm{Ba}$ will be used for this correlation. Table 22 shows the results. The table consists of four parts which represent Units $A, B, C$ and $D$.

An evaluation of Unit A shows a dominance of $\mathrm{CH}-132$ in the highest column followed by $\mathrm{CH}-131$ dominating the middle columns. $\mathrm{CH}-133$ and $\mathrm{CH}-$ 134 are dominant in the least column. The basic trend of relative elemental concentrations represented is shown in Figure 56 . When this trend is compared with the isopach map of Unit A in Plate II, the trend nearly bisects the lacustrine delta form represented and increases in a direction from the shore towards the lake center. The element concentrations are lower in the sandier upper delta deposits and become higher towards the more siltstone dominated lower delta and pro-delta deposits. The trend, core analysis and depositional model all support each other.

An evaluation of Unit $\mathrm{B}$ shows a dominance of $\mathrm{CH}-132$ and $\mathrm{CH}-134$ in the higher concentration columns and a dominance of $\mathrm{CH}-131$ and $\mathrm{CH}-133$ in the lower concentration columns. The trend represented is identical to that shown in Figure 55 for the Hanna No. 1 coal bed. When this trend is compared to the isopach map of Unit B in Plate III, the arrows representing increasing concentrations point in the direction of thinning. It is proposed that this is away from the thick, sandy channel deposits and towards the thinner silty overbank and back-swamp deposits. The geochemistry supports the proposed depositional model.

An evaluation of trends in Unit $\mathrm{C}$ shows a dominance of $\mathrm{CH}-131$ and $\mathrm{CH}-132$ in the higher concentration columns and a strong dominance of $\mathrm{CH}$ 133 in the least column. The trend definitely increases towards the northeast from $\mathrm{CH}-133$ to $\mathrm{CH}-131$ and then remains the same from $\mathrm{CH}-131$ to $\mathrm{CH}-132$ (Figure 57). (Note: Unit $\mathrm{C}$ is not present in $\mathrm{CH}-134$.$) The$ trend, when compared to the isopach map of Unit $C$ in Plate IV, is increasing towards the thick portion of the unit. This is explained by the presence of more heavy minerals in the coarser sand of the thicker, higher energy channel deposits of the braided river system.

With Unit D present in only two of the coreholes, $\mathrm{CH}-131$ and $\mathrm{CH}-$ 132 , and with the similarities of values represented, no real trend is proposed for the unit. The chart on Table 22 does show a slight dominance of $\mathrm{CH}-132$ over $\mathrm{CH}-131$.

\section{Local Stratigraphic Units - Within Each Hole}

This relative elemental concentration comparison is similar to that done for the local stratigraphic units on a site average basis in correlation \#2 This correlation, however, looks at each corehole separately to identify any trends anomalous to that shown in \#2, namely, units $A$ and $B$ with the highest concentrations, followed by Unit D, Unit $C$ and the Hanna No. 1 coal respectively. Only the elements $\mathrm{Fe}, \mathrm{Mg}, \mathrm{Ca}, \mathrm{Mn}, \mathrm{B}$, and $\mathrm{Ba}$ will be used for this correlation. The results are shown in Table 23. An examination of Table 23 showed the No. 1 coal to dominate least 
Table 22. Local stratigraphic units - hole to hole correlation.

\begin{tabular}{ccccc}
\hline \multicolumn{5}{c}{ UNIT A } \\
\hline Element & Highest & 2 & 3 & Least \\
\hline $\mathrm{Fe}$ & 132 & 131,133 & -- & 134 \\
$\mathrm{Mg}$ & 131,132 & -- & 134 & 133 \\
$\mathrm{Ca}$ & 133 & 131 & 132 & 134 \\
$\mathrm{Mn}$ & 131 & 134 & 132 & 133 \\
$\mathrm{~B}$ & 132 & 134 & 131 & 133 \\
$\mathrm{Ba}$ & 132 & 133 & 131 & 134 \\
\hline
\end{tabular}

\begin{tabular}{cccc}
\hline \multicolumn{4}{c}{ UNIT C } \\
\hline Element & Highest & 2 & Least \\
\hline $\mathrm{Fe}$ & 131,132 & -- & 133 \\
$\mathrm{Mg}$ & 131 & 132 & 133 \\
$\mathrm{Ca}$ & 132 & 131 & 133 \\
$\mathrm{Mn}$ & 131 & 132 & 133 \\
$\mathrm{~B}$ & 131 & 132 & 133 \\
$\mathrm{Ba}$ & 132 & 133 & 131 \\
\hline
\end{tabular}

\begin{tabular}{ccccc}
\hline \multicolumn{5}{c}{ UNIT B } \\
\hline Element & Highest & 2 & 3 & Least \\
\hline $\mathrm{Fe}$ & 134 & 132 & 131 & 133 \\
$\mathrm{Mg}$ & 132 & 134 & 131 & 133 \\
$\mathrm{Ca}$ & 133 & 132 & 134 & 131 \\
$\mathrm{Mn}$ & 134 & 131 & 132 & 133 \\
$\mathrm{~B}$ & 132 & 134 & 131 & 133 \\
$\mathrm{Ba}$ & 132 & 133 & 134 & 131 \\
\hline
\end{tabular}

\begin{tabular}{ccc}
\hline & UNIT D \\
\hline Element & Highest & Least \\
\hline $\mathrm{Fe}$ & 132 & 131 \\
$\mathrm{Mg}$ & 131 & 132 \\
$\mathrm{Ca}$ & 131 & 132 \\
$\mathrm{Mn}$ & 132 & 131 \\
$\mathrm{~B}$ & 132 & 131 \\
$\mathrm{Ba}$ & 132 & 131 \\
\hline
\end{tabular}




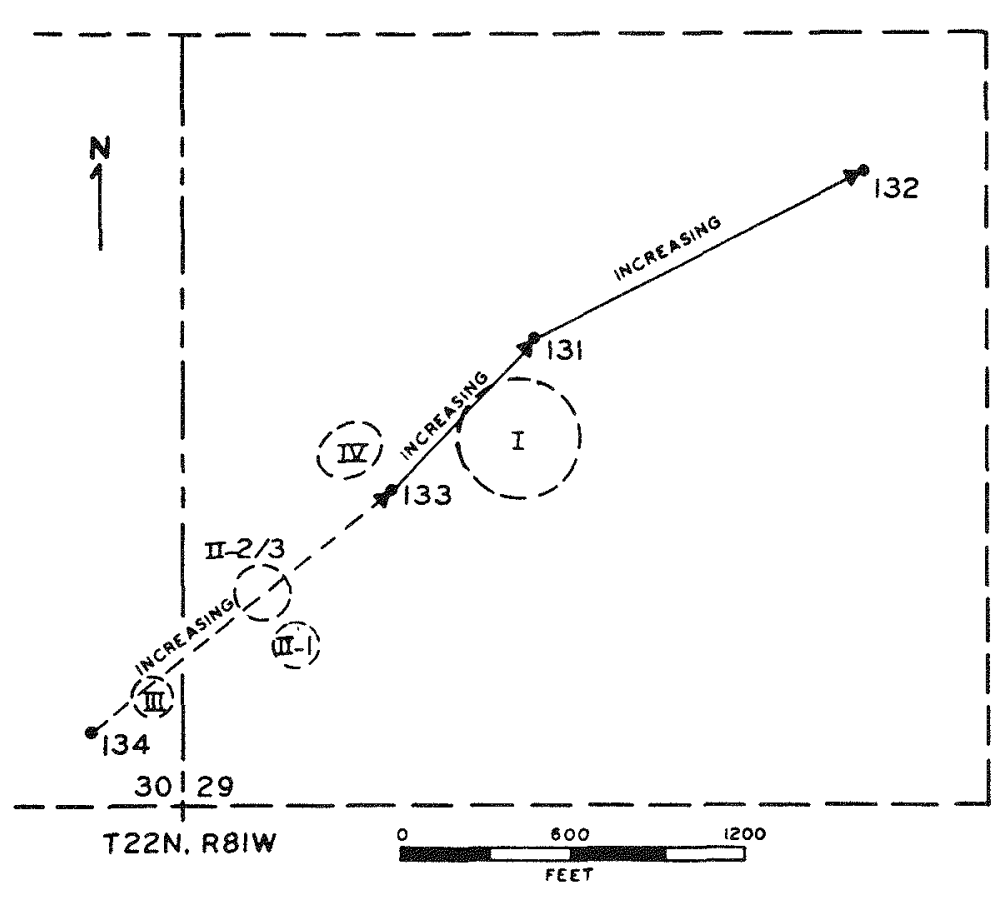

Figure 56. Diagrammatic representation of element concentration trends in Unit A, Hanna UCG site.

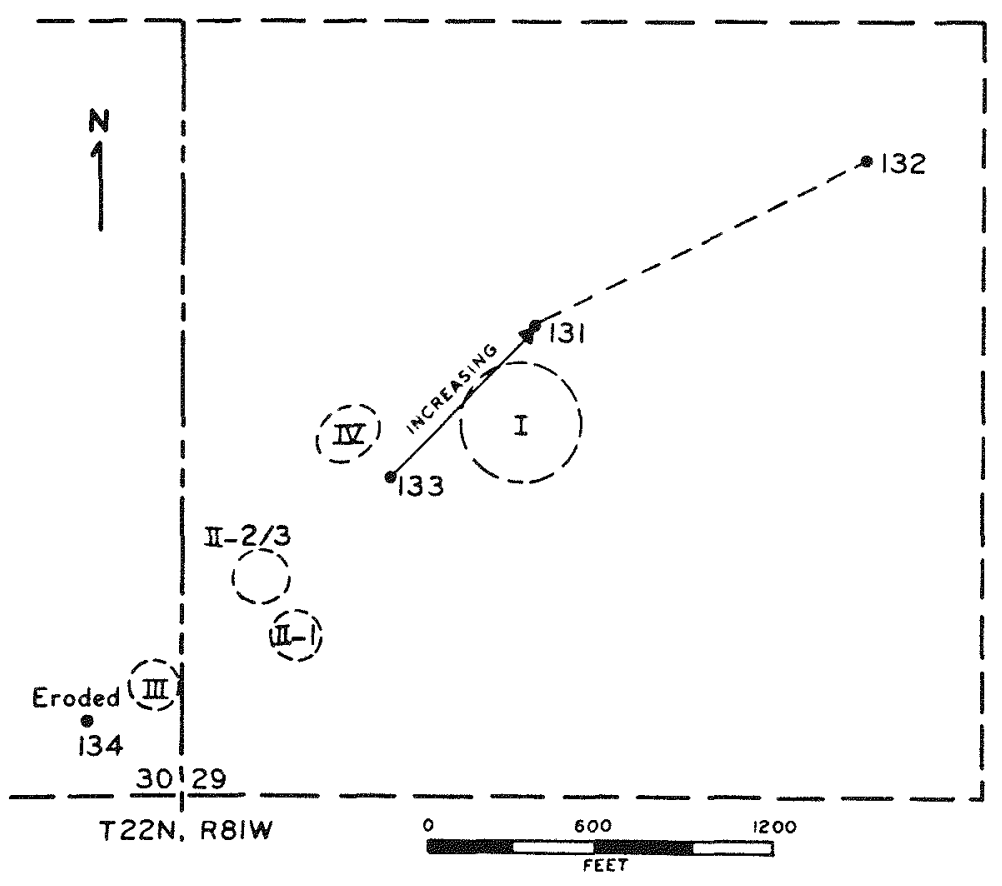

Figure 57. Diagrammatic representation of element concentration trends in Unit C, Hanna UCG site. 
values in 211 holes. The general pattern is represented fairly well in three of the four coreholes, $\mathrm{CH}-132, \mathrm{CH}-133$, and $\mathrm{CH}-134$. The pattern in $\mathrm{CH}-132$ is identical to the overall average pattern with element concentration values decreasing from $\mathrm{A}, \mathrm{B}, \mathrm{D}, \mathrm{C}$, to No. $1 . \mathrm{CH}-133$ has no Unit $D$ present but its pattern fits the trend being $A, B, C$, to No. 1 . No real comparison can be done for $\mathrm{CH}-134$ as both Unit $D$ and Unit $\mathrm{C}$ are eroded away in this area. $\mathrm{CH}-134$ is somewhat anomalous as Unit B seems to dominate over Unit $A$. $\quad \mathrm{CH}-131$ fits the general trend with Unit. $A$ being highest and the No. 1 coal being least, but Units $D$ and $C$ have higher concentration levels than Unit B. The patterns are shown in Figure 58 .

Table 23. Local stratigraphic units - within each hole.

\begin{tabular}{ccccc}
\hline \multicolumn{2}{c}{$\mathrm{CH}-131$} & & \\
\hline Element & Highest & 2 & 3 & Least \\
\hline $\mathrm{Fe}$ & $\mathrm{B}, \mathrm{D}$ & - & $\mathrm{A}, \mathrm{C}$ & $\ldots$ \\
$\mathrm{Mg}$ & $\mathrm{A}$ & $\mathrm{D}$ & $\mathrm{C}$ & $\mathrm{B}$ \\
$\mathrm{Ca}$ & $\mathrm{A}$ & $\mathrm{D}$ & $\mathrm{C}$ & $\mathrm{B}$ \\
$\mathrm{Mn}$ & $\mathrm{A}$ & $\mathrm{C}$ & $\mathrm{B}$ & $\mathrm{D}$ \\
$\mathrm{B}$ & $\mathrm{D}$ & $\mathrm{A}$ & $\mathrm{B}$ & $\mathrm{C}$ \\
$\mathrm{Ba}$ & $\mathrm{C}$ & $\mathrm{A}$ & $\mathrm{D}$ & $\mathrm{B}$ \\
\hline
\end{tabular}

\begin{tabular}{ccccc}
\hline \multicolumn{5}{c}{$\mathrm{CH}-132$} \\
\hline Element & Highest & 2 & 3 & Least \\
\hline $\mathrm{Fe}$ & $\mathrm{A}$ & $\mathrm{B}$ & $\mathrm{D}$ & $\mathrm{C}$ \\
$\mathrm{Mg}$ & $\mathrm{A}$ & $\mathrm{B}$ & $\mathrm{D}$ & $\mathrm{C}$ \\
$\mathrm{Ca}$ & $\mathrm{A}$ & $\mathrm{B}$ & $\mathrm{C}$ & $\mathrm{D}$ \\
$\mathrm{Mn}$ & $\mathrm{C}$ & $\mathrm{D}$ & $\mathrm{A}$ & $\mathrm{B}$ \\
$\mathrm{B}$ & $\mathrm{B}$ & $\mathrm{A}$ & $\mathrm{D}$ & $\mathrm{C}$ \\
$\mathrm{Ba}$ & $\mathrm{C}$ & $\mathrm{B}$ & $\mathrm{A}$ & $\mathrm{D}$ \\
\hline
\end{tabular}

\begin{tabular}{cccc}
\hline \multicolumn{4}{c}{$\mathrm{CH}-133$} \\
\hline Element & Highest & 2 & Least \\
\hline $\mathrm{Fe}$ & $\mathrm{B}$ & $\mathrm{A}$ & $\mathrm{C}$ \\
$\mathrm{Mg}$ & $\mathrm{A}, \mathrm{B}$ & -- & $\mathrm{C}$ \\
$\mathrm{Ca}$ & $\mathrm{A}$ & $\mathrm{B}$ & $\mathrm{C}$ \\
$\mathrm{Mn}$ & $\mathrm{A}$ & $\mathrm{C}$ & $\mathrm{B}$ \\
$\mathrm{B}$ & $\mathrm{B}$ & $\mathrm{A}$ & $\mathrm{C}$ \\
$\mathrm{Ba}$ & $\mathrm{C}$ & $\mathrm{A}$ & $\mathrm{B}$ \\
\hline
\end{tabular}

\begin{tabular}{ccc} 
& $\mathrm{CH}-134$ & \\
\hline Element & Highest & Least \\
\hline $\mathrm{Fe}$ & $\mathrm{B}$ & $\mathrm{A}$ \\
$\mathrm{Mg}$ & $\mathrm{A}$ & $\mathrm{B}$ \\
$\mathrm{Ca}$ & $\mathrm{A}$ & $\mathrm{B}$ \\
$\mathrm{Mn}$ & $\mathrm{B}$ & $\mathrm{A}$ \\
$\mathrm{B}$ & $\mathrm{B}$ & $\mathrm{A}$ \\
$\mathrm{Ba}$ & $\mathrm{B}$ & $\mathrm{A}$ \\
\hline
\end{tabular}




$$
\begin{gathered}
A, B, \frac{\text { AVERAGE }}{D, C, N o .1} \\
A, D, \frac{C H-131}{C, B, N o .1} \\
A, B, \frac{C H-132}{D, C,} \text { No. } 1 \\
A, \frac{C H-133}{C, N o, 1} \\
B, \frac{C H-134}{A, N o}, 1
\end{gathered}
$$

Figure 58. Graphic representation of local stratigraphic unit correlations within each hole, Hanna UCG site.

The anomaly in $\mathrm{CH}-131$ is probably the result of overlapping of trends discussed in the previous correlation \#4. Units $A, C$ and $D$ all have higher concentration values in this corehole ( $\mathrm{CH}-131)$ as compared to the other coreholes, whereas Unit B has lower values in $\mathrm{CH}-131 \mathrm{com}-$ pared to the others. The trend for Unit $B$ is opposite to that for Units $\mathrm{A}, \mathrm{C}$ and $\mathrm{D}$, trending away from $\mathrm{CH}-131$ (Figure 55) instead of towards $\mathrm{CH}-$ 131 (Figures 56 and 57). So, Units $C$ and $D$ have anomalous ly higher values in $\mathrm{CH}-131$ than does Unit $\mathrm{B}$.

\section{Coal to Total Overburden - Within Each Hole}

This correlation is similar to that done for the site average but takes each hole separately to locate any anomalies. Inspection of the lower halves of Tables 14 through 17 shows the trends in each hole to be very similar to that shown for the whole site. However, $\mathrm{CH}-132$ tends to have coal values more similar to overburden values.

\section{Conctusions}

From the preceding correlations, the proposed depositional environments and unit distribution patterns for the local stratigraphic units are supported. It also appears that element concentration is related to sandstone percentage. Elemental concentrations tend to be lower in lithologies with higher sandstone content due to the greater dominance of silicon in the rock. Evidently the rock lithotype has a strong effect on element concentrations and an analysis from this viewpoint would be appropriate and useful. 


\section{Lithotype Analys is}

In this section the geochemistry of the Hanna UCG site will be evaluated on the basis of rock 1ithotype. Three lithotype groups will be discussed as follows: 1) sandstones and conglomerates, 2) silts and silty sandstones, and 3) mudstones and shales. Coals will not be discussed because their geochemistry has aiready been established in the previous section (correlations \#1, \#2, \#3 and \#6).

The data from $\mathrm{CH}-131, \mathrm{CH}-132, \mathrm{CH}-133$ and $\mathrm{CH}-134$ used in the previous section was used for accurate comparative value and to establish pre-burn baseline values. $\mathrm{CH}-131$ and $\mathrm{CH}-132$ are shown in Table $24, \mathrm{CH}-$ 133 and 134 are on Table 25, and an average of the four coreholes is shown in Table 26. The values in Table 26 average somewhat higher as compared to the average total overburden values shown in the bottom of Table 19 because the coal beds in the overburden units were omitted.

The 7ithotype correlations are shown in Tables 27-29. The average trend shown in Table 29 is a dominance of the mudstones and shales lithotype in the high column, followed by a dominance of the siltstones and silty sandstones lithotype in the middle column and a dominance of the sandstones and conglomerates lithotype in the low values column. This is shown numerically in Figure 59 verifying many of the observations in the previous section on correlations done by local stratigraphic units. The sandier lithologies exhibit a dominance toward lower concentration values. The counterpart is also true. As the sandstones become "dirtier" and silty, the concentration values tend to rise. The depositional environment speculations made for the various units in the previous section would seem to be valid hypotheses.

$\begin{array}{ccc}\text { High } & \frac{2}{\text { Low }} \\ \text { *MS-11 } & \text { MS -5 } & \text { MS }-4 \\ S S-7 & \text { *SS-12 } & S S-1 \\ S C-2 & S C-3 & * S C-15\end{array}$

Figure 59. Numeric representation of relative element concentrations in three basic lithotypes. (*-dominant lithotype) 
Table 24. Semi-quantitative spectrographic analysis by lithotype for $\mathrm{CH}-131$ and $\mathrm{CH}-132$, Hanna UCG site.

$\mathrm{CH}-131$

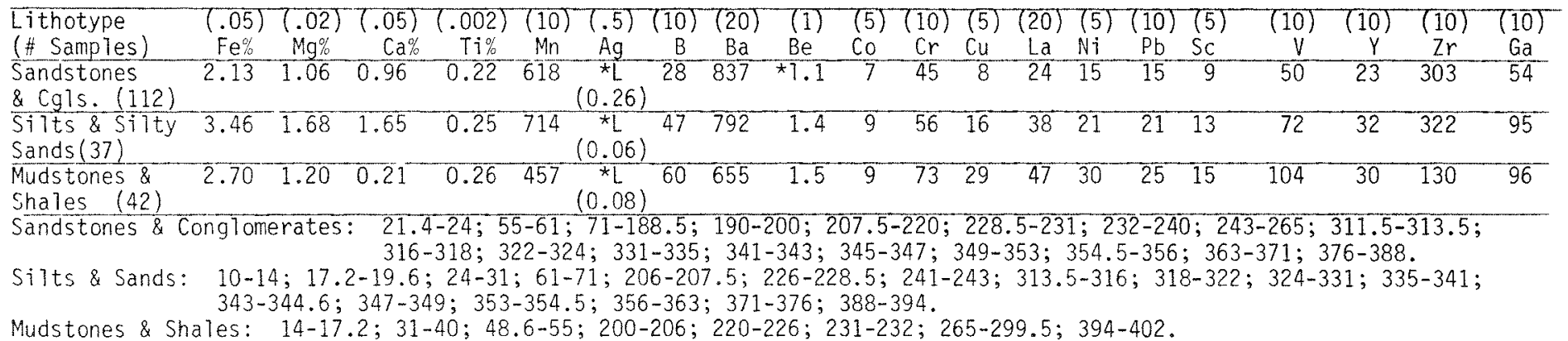

\section{CH-132}

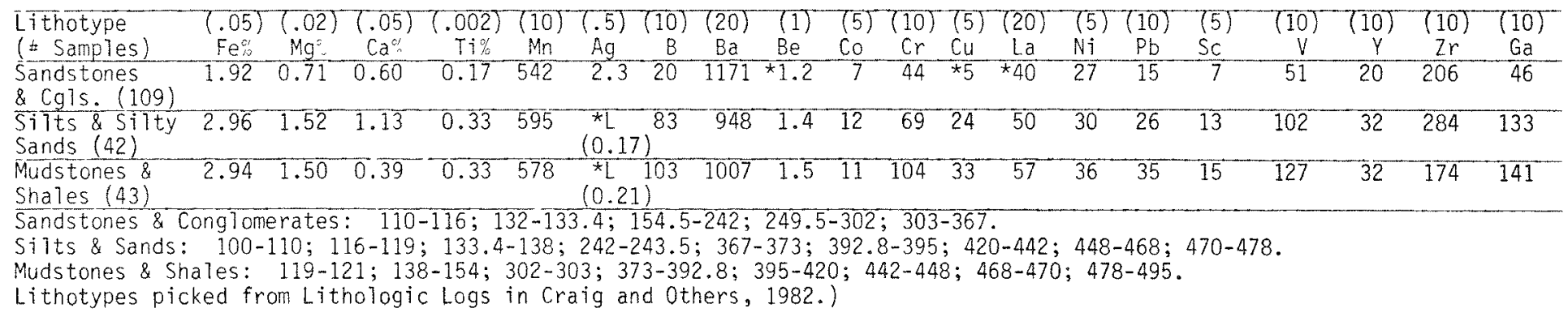


Table 25. Semi-quantitative spectrographic analysis by lithotype for $\mathrm{CH}-133$ and $\mathrm{CH}-134$, Hanna UCG site.

$\mathrm{CH}-133$

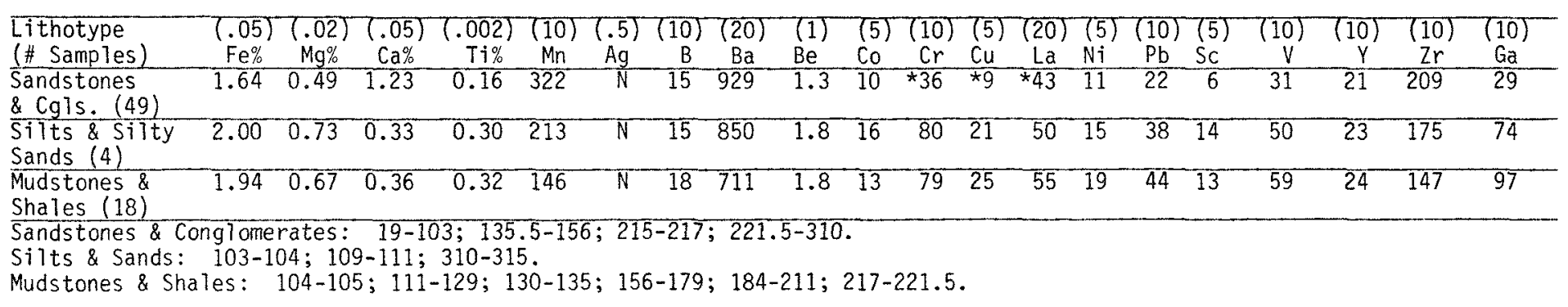

CH-134

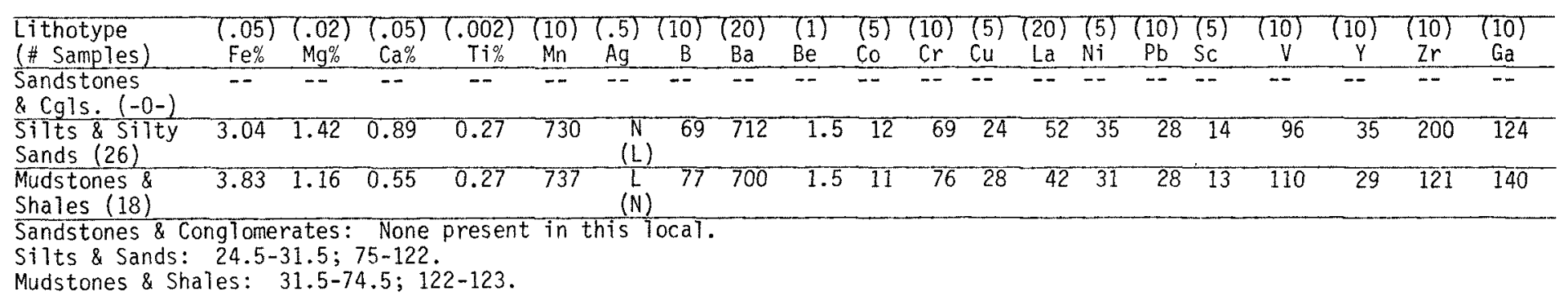


Table 26. Semi-quantitative spectrographic analysis by lithotype, Hanna UCG site.

\section{AVERAGE}

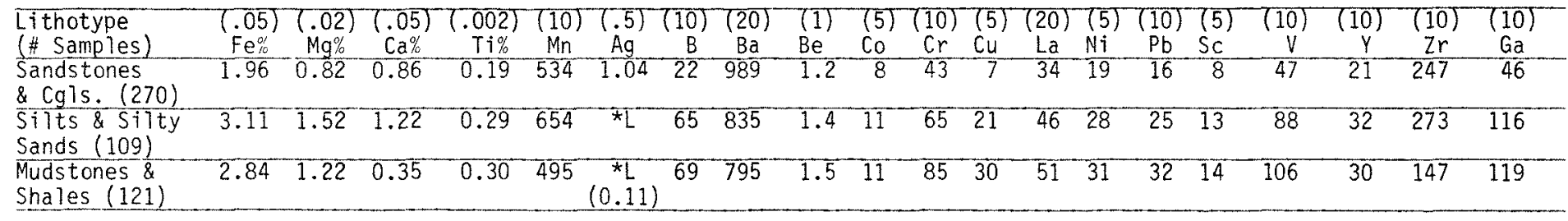


Table 27. Lithotype correlations for $\mathrm{CH}-131$ and $\mathrm{CH}-132$, Hanna UCG site.

$\mathrm{CH}-131$

\begin{tabular}{|c|c|c|c|}
\hline Element & Highest & 2 & Least \\
\hline $\mathrm{Fe}$ & SS & MS & SC \\
\hline $\mathrm{Mg}$ & SS & MS & SC \\
\hline $\mathrm{Ca}$ & SS & SC & MS \\
\hline $\mathrm{Ti}$ & MS & SS & SC \\
\hline$M n$ & SS & SC & MS \\
\hline $\mathrm{Ag}$ & SC & MS & SS \\
\hline B & MS & SS & SC \\
\hline $\mathrm{Ba}$ & SC & SS & MS \\
\hline $\mathrm{Be}$ & MS & SS & SC \\
\hline Co & MS,SS & $\cdots$ & SC \\
\hline $\mathrm{Cr}$ & MS & SS & SC \\
\hline $\mathrm{Cu}$ & MS & SS & SC \\
\hline La & MS & SS & SC \\
\hline $\mathrm{Ni}$ & MS & SS & SC \\
\hline $\mathrm{Pb}$ & MS & SS & SC \\
\hline SC & MS & SS & SC \\
\hline V & MS & SS & SC \\
\hline Y & SS & MS & SC \\
\hline $\mathrm{Zr}$ & SS & SC & MS \\
\hline Ga & MS & SS & SC \\
\hline
\end{tabular}

SC - Sandstones \& Conglomerates

SS - Silts \& Silty Sandstones

MS - Mudstones \& Shates

$\mathrm{CH}-132$

\begin{tabular}{|c|c|c|c|}
\hline Element & Highest & 2 & Least \\
\hline $\mathrm{Fe}$ & SS & MS & SC \\
\hline $\mathrm{Mg}$ & SS & MS & SC \\
\hline $\mathrm{Ca}$ & SS & $\mathrm{SC}$ & MS \\
\hline$T i$ & MS, SS & -- & SC \\
\hline$M n$ & SS & MS & SC \\
\hline $\mathrm{Ag}$ & SC & MS & SS \\
\hline B & MS & SS & SC \\
\hline $\mathrm{Ba}$ & SC & MS & SS \\
\hline $\mathrm{Be}$ & MS & SS & SC \\
\hline $\mathrm{Co}$ & SS & MS & SC \\
\hline $\mathrm{Cr}$ & MS & SS & SC \\
\hline $\mathrm{Cu}$ & MS & SS & SC \\
\hline La & MS & SS & SC \\
\hline $\mathrm{Ni}$ & MS & SS & SC \\
\hline $\mathrm{Pb}$ & MS & SS & SC \\
\hline SC & MS & SS & SC \\
\hline V & MS & SS & SC \\
\hline y & SS,MS & -- & SC \\
\hline $2 r$ & SS & $\mathrm{SC}$ & MS \\
\hline $\mathrm{Ga}$ & MS & SS & SC \\
\hline
\end{tabular}


Table 28. Lithotype correlations for $\mathrm{CH}-133$ and $\mathrm{CH}-134$, Hanna UCG site.

$\mathrm{CH}-133$

\begin{tabular}{|c|c|c|c|}
\hline Element & Highest & 2 & Least \\
\hline $\mathrm{Fe}$ & SS & MS & SC \\
\hline $\mathrm{Mg}$ & SS & MS & SC \\
\hline $\mathrm{Ca}$ & SC & MS & SS \\
\hline$T i$ & MS & SS & SC \\
\hline Mn & SC & SS & MS \\
\hline $\mathrm{Ag}$ & -- & -- & $-\cdots$ \\
\hline B & MS & SS, SC & -- \\
\hline $\mathrm{Ba}$ & SC & SS & MS \\
\hline $\mathrm{Be}$ & SS,MS & -- & SC \\
\hline Co & SS & MS & SC \\
\hline $\mathrm{Cr}$ & SS & MS & SC \\
\hline $\mathrm{Cu}$ & MS & SS & SC \\
\hline La & MS & SS & SC \\
\hline $\mathrm{Ni}$ & MS & SS & SC \\
\hline $\mathrm{Pb}$ & MS & SS & SC \\
\hline Sc & SS & MS & SC \\
\hline V & MS & SS & SC \\
\hline Y & MS & SS & SC \\
\hline Zr & SC & SS & MS \\
\hline Ga & MS & SS & SC \\
\hline
\end{tabular}

$\mathrm{CH}-134$

(Note: No sandstones \& conglomerates lithotype present.

\begin{tabular}{|c|c|c|}
\hline Element & Highest & Least \\
\hline $\mathrm{Fe}$ & MS & SS \\
\hline $\mathrm{Mg}$ & SS & MS \\
\hline $\mathrm{Ca}$ & SS & MS \\
\hline$T i$ & SS,MS & -- \\
\hline Mn & MS & SS \\
\hline $\mathrm{Ag}$ & MS & SS \\
\hline B & MS & SS \\
\hline $\mathrm{Ba}$ & SS & MS \\
\hline $\mathrm{Be}$ & SS,MS & -- \\
\hline $\mathrm{Co}$ & SS & MS \\
\hline $\mathrm{Cr}$ & MS & SS \\
\hline $\mathrm{Cu}$ & MS & SS \\
\hline La & SS & MS \\
\hline $\mathrm{Ni}$ & SS & MS \\
\hline $\mathrm{Pb}$ & SS,MS & -- \\
\hline SC & SS & MS \\
\hline V & MS & SS \\
\hline Y & SS & MS \\
\hline $\mathrm{Zr}$ & SS & MS \\
\hline $\mathrm{Ga}$ & MS & SS \\
\hline
\end{tabular}

SC - Sandstones \& Conglomerates

SS - Silts \& Silty Sandstones

MS - Mudstones \& Shales 
Table 29. Lithotype correlations of average baseline, Hanna UCG site.

\section{AVERAGE}

\begin{tabular}{|c|c|c|c|}
\hline Element & High & 2 & Low \\
\hline $\mathrm{Fe}$ & SS & MS & SC \\
\hline $\mathrm{Mg}$ & SS & MS & SC \\
\hline $\mathrm{Ca}$ & SS & SC & MS \\
\hline Ti & MS & SS & SC \\
\hline$M n$ & SS & $\mathrm{SC}$ & MS \\
\hline $\mathrm{Ag}$ & SC & MS & SS \\
\hline$B$ & MS & SS & SC \\
\hline $\mathrm{Ba}$ & SC & SS & MS \\
\hline $\mathrm{Be}$ & MS & SS & SC \\
\hline Co & SS & MS & SC \\
\hline $\mathrm{Cr}$ & MS & SS & SC \\
\hline $\mathrm{Cu}$ & MS & SS & SC \\
\hline La & MS & SS & SC \\
\hline $\mathrm{Ni}$ & MS & SS & SC \\
\hline $\mathrm{Pb}$ & MS & SS & SC \\
\hline Sc & MS & SS & SC \\
\hline V & MS & SS & SC \\
\hline$Y$ & SS & MS & SC \\
\hline $\mathrm{Zr}$ & SS & SC & MS \\
\hline $\mathrm{Ga}$ & MS & SS & SC \\
\hline
\end{tabular}

SC - Sandstones \& Conglomerates; SS - Silts and Silty Sandstones;

MS - Mudstones and Shales 
Some anomalies to the previously discussed trend are: 1) the sandstones and conglomerates lithotype has the highest average concentrations of silver and barium, and 2) the mudstones and shales lithotype has the lowest average concentrations for calcium, manganese, barium and zirconium (see Table 29).

From corehole to corehole, $\mathrm{CH}-131, \mathrm{CH}-132$ and $\mathrm{CH}-133$ (Tables 27 and 28) match the average trend very well. $\mathrm{CH}-134$ (Table 28) contains no rocks of the sandstones and conglomerates lithotype but does provide a good relative comparison of the silts and silty sandstones lithotype with the mudstones and shales lithotype. In this particular corehole the trend is somewhat anomalous as the two lithotypes are equally represented in both columns.

Analytical Analysis

Genera 1

Several hundred analytical analyses were done on samples from the Hanna UCG Site. A complete sequence was done on $\mathrm{CH}-133$ from $19 \mathrm{ft}$. to the bottom of the Hanna No. 1 coal (346 ft.). This core section was analyzed to establish baseline values for Unit $C$, Unit $B$, Unit $A$ and the Hanna No. 1 coal. No Unit $D$ is present in $\mathrm{CH}-133$. One-hundred and five samples were analyzed and averaged. The results are shown in Table 30. Aluminum, lithium, magnesium, rubidium, silicon, sodium, and potassium were analyzed using the Atomic Absorption Spectrophotometer. Phosphorous analyses were completed using a colorimetric method. The sulfur forms were determined using gravimetric methods.

\section{Correlations}

The coal bed, as expected, is highest in $\mathrm{Sb}, \mathrm{Li}, \mathrm{P}, \mathrm{SO}_{4}, \mathrm{~S}$ (tot), and $\mathrm{S}\left(\mathrm{H}_{2} \mathrm{O}\right)$. It is also highest in $\mathrm{CuO}, \mathrm{PbO}$, and $\mathrm{Fe}^{+2}$. The value obtained for $\mathrm{Fe}^{+2}$ is 1.58 percent as compared to 0.90 percent obtained for $\mathrm{Fe}$ in the spectrographic analysis (Table 16). An interesting observation is that the values for $\mathrm{CuO}, \mathrm{PbO}$, and $\mathrm{ZnO}$ are significantly higher compared to those for CuS, PbS, and $\mathrm{ZnS}$. The coal bed has the lowest values for $\mathrm{Al}, \mathrm{Ca}, \mathrm{Pb}$ (tot), $\mathrm{PbS}, \mathrm{Mg}, \mathrm{K}, \mathrm{Rb}, \mathrm{Si}, \mathrm{S}, \mathrm{Zn}$ (tot), $\mathrm{ZnO}$, and $\mathrm{ZnS}$. The low values for most of these elements is due to the low content of feldspars, micas, and quartz as compared to the overburden units.

Among the overburden units, Unit $\mathrm{A}$ is highest in $\mathrm{Ca}, \mathrm{Fe}^{+2}, \mathrm{~Pb}$ (tot), $\mathrm{PbS} . \mathrm{Mg}, \mathrm{P}, \mathrm{Rb}$, the sulfurs, $\mathrm{Zn}$ (tot), and $\mathrm{ZnS}$. It is lowest in AT, Li, $\mathrm{Si}, \mathrm{Na}$, and $\mathrm{ZnO}$. This is due to a higher percentage of siltstones and 'dirty' sandstones in this unit as compared with Units $B$ and $C$. The high sulfur content is indicative of a more reducing environment of deposition, and supports the lacustrine depositional model and core descriptions of Unit A.

Unit $B$ is highest in $A 1$, CuO, CuS, Si, and $Z n O$. It is lowest in $\mathrm{Ca}, \mathrm{K}, \mathrm{Rb}, \mathrm{Zn}$ (tot), and $\mathrm{ZnS}$. This represents a somewhat less reducing environment than Unit $A$. High $A T$ content is probably due to the higher 
Table 30. Analytical analys is of $\mathrm{CH}-133$, Hanna UCG site.

\begin{tabular}{|c|c|c|c|c|c|c|c|c|c|c|c|c|}
\hline $\begin{array}{l}\text { Unit } \\
\text { (\# Samples) }\end{array}$ & Al & $\mathrm{Ca}$ & CuO & cus & $\mathrm{Fe}^{+2}$ & $\mathrm{~Pb}_{\text {tot }}$ & $\mathrm{PbO}$ & $\mathrm{PbS}$ & $\mathrm{Li}$ & $\mathrm{Mg}$ & P & K \\
\hline Unit C (23) & $7.8 \%$ & $0.68 \%$ & $\star 3.8$ & $\star 13.1$ & $0.19 \%$ & 26 & $\star 3.0$ & 26 & 29.8 & $0.80 \%$ & *62 & $2.56 \%$ \\
\hline Unit B (27) & $8.7 \%$ & $0.55 \%$ & $* 9.3$ & 32.3 & $1.01 \%$ & 32 & $\star 3.0$ & 30 & 20.5 & $1.10 \%$ & $\star 71$ & $1.67 \%$ \\
\hline Unit A (23) & $7.8 \%$ & $2.73 \%$ & $\star 8.0$ & 15.3 & $1.35 \%$ & 52 & $\star 3.0$ & 49 & 10.9 & $3.09 \%$ & $\star 77$ & $2.25 \%$ \\
\hline No. 1 (32) & $4.1 \%$ & $0.29 \%$ & 25.6 & 19.4 & $1.58 \%$ & 26 & 26 & 9 & 94.0 & $0.39 \%$ & 152 & $0.32 \%$ \\
\hline
\end{tabular}

\begin{tabular}{|c|c|c|c|c|c|c|c|c|c|c|c|}
\hline $\begin{array}{l}\text { Unit } \\
\text { (\# Samples) }\end{array}$ & $\overline{\mathrm{Rb}}$ & Si & $\mathrm{Na}$ & $\mathrm{SO}_{4}$ & $\mathrm{~S}_{+}$ & $\mathrm{S}_{\mathrm{H}_{2} \mathrm{O}}$ & $\overline{S_{i d a}}$ & $\mathrm{Sb}$ & $Z n_{\text {tot }}$ & $\mathrm{ZnO}$ & $\mathrm{ZnS}$ \\
\hline Unit C (23) & 21 & $35.2 \%$ & $1.56 \%$ & $0.51 \%$ & $0.30 \%$ & $0.22 \%$ & $0.62 \%$ & $\star 1.0$ & 51 & 38 & 19 \\
\hline Unit B (27) & 20 & $35.2 \%$ & $0.58 \%$ & $0.68 \%$ & $0.42 \%$ & $0.22 \%$ & $0.79 \%$ & $\star 1.0$ & 44 & 46 & 11 \\
\hline Unit A (23) & 51 & $32.7 \%$ & $0.52 \%$ & $0.63 \%$ & $0.50 \%$ & $0.29 \%$ & $0.90 \%$ & $\star 1.0$ & 65 & 36 & 33 \\
\hline No. 1 (32) & $\star 13$ & $6.8 \%$ & $0.88 \%$ & $1.53 \%$ & $0.6 \overline{2} \%$ & $0.48 \%$ & $0.24 \%$ & 44 & 36 & 34 & $\star 7$ \\
\hline
\end{tabular}

Units picked from lithologic log in Craig et a1, 1982. Section continuous from $19 \mathrm{ft}$. to $346 \mathrm{ft}$.

* - Values in the data denoted with < were valued equal to the number $(\mathrm{e} . \mathrm{g} .<2.0=2.0)$. 
percentage of shales and mudstones in the unit as compared with Units $A$ and $C$. This proposed higher percentage of shales and mudstones in Unit $B$ is supported by depositional models and core descriptions. Unit $B$ is generally bounded on both the top and bottom by thick $\left(10^{\prime}-50^{\prime}\right)$ shale beds whereas Unit $A$ generally has only a thin shale underneath. Unit $C$ has practically no shale in the sequence.

Unit $\mathrm{C}$ is highest in $\mathrm{Li}, \mathrm{K}, \mathrm{Si}$ and $\mathrm{Na}$ and is lowest in $\mathrm{Al}, \mathrm{CuO}$, CuS, $\mathrm{Fe}^{+2}, \mathrm{~Pb}$ (tot), $\mathrm{PbS}, \mathrm{Mg}, \mathrm{P}$, and the sulfurs. These element concentrations are representative of the high sand content of this unit with practicaliy no silts or shales to add $A T, M g, P$, and $S$. The $L i, K$ and $\mathrm{Na}$ is probably representative of the heavy mineral constituents in the conglomerates and coarse sands of the unit as compared to the finergrained character of Units $A$ and $B$ where these minerals would not be so abundant.

The Hanna No. 1 coal was analyzed in five baseline coreholes ( $\mathrm{CH}-$ 131, $\mathrm{CH}-132, \mathrm{CH}-133, \mathrm{CH}-134$, and $2 \mathrm{HP}-170$ ) and the results are shown in Table 31. Average baseline values for the Hanna UCG Site are shown on the bottom row. The trends among the five baseline coreholes are shown in Figure 60.

CH-131 tends towards slightly lower elemental concentrations than $\mathrm{CH}-132$, and the nigher $\mathrm{Si}$ content suggests that $\mathrm{CH}-132$ was nearer the swamp margin receiving a higher sediment influx. The relationship of $\mathrm{CH}-133$ to $\mathrm{CH}-134$ is opposite of that represented in Figure 55 and Table 21. Previous correlations showed a strong tendency for $\mathrm{CH}-134$ to have higher concentrations than $\mathrm{CH}-133$, but $\mathrm{CH}-133$ is higher than $\mathrm{CH}-134$ in this analysis for nearly all elements. In fact, $\mathrm{CH}-133$ represents the highest concentration values for many elements over all five coreholes. $\mathrm{CH}-133$ 's highest concentration values for $\mathrm{A}], \mathrm{Li}, \mathrm{Mg}, \mathrm{Si}$ and $\mathrm{Na}$ strongly suggest that this locale was so situated in the depositional environment as to have received the highest influx of detrital sediments (quartz, plagioclase, feldspar, etc.). The trend for the Hanna No. 1 coal represented in this analysis is shown in Figure 60 (compare to Figure 55). This anomaly may be due to the poorer quality data of the analytical analyses as compared to the semi-quantitative spectrographic analyses. 
Table 31. Analytical analysis of the Hanna No. 1 coal, Hanna UCG site.

\begin{tabular}{lccccccccccccc}
\hline $\begin{array}{l}\text { Corehole } \\
\text { \# Samples) }\end{array}$ & A1 & Ca & CuO & CuS & Fe & Pb tot & Pbo & PbS & Li & Mg & P & $K$ \\
\hline $\mathrm{CH}-131(17)$ & $1.3 \%$ & $0.71 \%$ & 11.4 & $\star 10.4$ & $0.29 \%$ & 18 & 14 & 13 & 40.0 & $0.17 \%$ & $\star 50$ & $0.17 \%$ \\
\hline $\mathrm{CH}-132$ & $(18)$ & $1.6 \%$ & $0.57 \%$ & 12.5 & 10.5 & $0.72 \%$ & 16 & 16 & 11 & 63.8 & $0.17 \%$ & $\star 50$ & $0.23 \%$ \\
\hline $\mathrm{CH}-133(32)$ & $4.1 \%$ & $0.29 \%$ & 25.6 & 19.4 & $1.58 \%$ & 26 & 26 & 9 & 94.0 & $0.39 \%$ & 152 & $0.32 \%$ \\
\hline $\mathrm{CH}-134(29)$ & $2.2 \%$ & $0.70 \%$ & 20.7 & 12.4 & $0.75 \%$ & 15 & 15 & 10 & 74.8 & $0.35 \%$ & $\star 50$ & $0.37 \%$ \\
\hline $2 \mathrm{HP}-170(28)$ & $4.2 \%$ & $0.64 \%$ & $\star 3.0$ & 13.5 & $0.73 \%$ & 30 & $\star 3$ & 30 & $\star 5.0$ & $0.33 \%$ & $\star 50$ & $0.55 \%$ \\
\hline Average (124) & $2.9 \%$ & $0.56 \%$ & 15.5 & 13.9 & $0.89 \%$ & 22 & 15 & 15 & 57.6 & $0.31 \%$ & $\star 76$ & $0.35 \%$ \\
\hline
\end{tabular}

* - values in the data denoted with < were valued equal to the number $(\mathrm{e} . \mathrm{g} .<2.0=2.0)$.

\begin{tabular}{|c|c|c|c|c|c|c|c|c|c|c|c|}
\hline $\begin{array}{l}\text { Corehole } \\
\text { (\# Samples) }\end{array}$ & $\mathrm{Rb}$ & $\mathrm{Si}$ & $\mathrm{Na}$ & $\mathrm{SO}_{4}$ & $s_{\text {tot }}$ & $\mathrm{S}_{\mathrm{H} 20}$ & $S_{i d e}$ & $\mathrm{Sb}$ & $\overline{Z n_{t_{0}}}$ & $\mathrm{ZnO}$ & $\mathrm{ZnS}$ \\
\hline $\mathrm{CH}-131(17)$ & 41 & $3.2 \%$ & $0.23 \%$ & - & - & - & - & $* 1.0$ & 72 & 24 & 56 \\
\hline$\overline{\mathrm{CH}-132(18)}$ & 53 & $3.8 \%$ & $0.30 \%$ & - & $\cdots$ & - & -- & $\star 1.0$ & 62 & 25 & 44 \\
\hline $\mathrm{CH}-133(32)$ & $\star 13$ & $6.8 \%$ & $0.88 \%$ & $1.53 \%$ & $0.62 \%$ & $0.48 \%$ & $0.24 \%$ & 44 & 36 & 34 & $* 7$ \\
\hline $\mathrm{CH}-134(29$ & 65 & $5.0 \%$ & $0.28 \%$ & -- & -- & - & -- & $\star 1.0$ & 64 & 37 & 35 \\
\hline $2 \mathrm{HP}-170(28)$ & $\star 1$ & $0.8 \%$ & $0.32 \%$ & $2.44 \%$ & $1.11 \%$ & $0.74 \%$ & $0,92 \%$ & $\star 1.0$ & 87 & $\star 12$ & 80 \\
\hline Average (124 & $\star 32$ & $4.1 \%$ & $0.44 \%$ & $1.95 \%$ & $0.85 \%$ & $0.60 \%$ & $0.56 \%$ & $\star 12$ & 63 & 27 & 42 \\
\hline
\end{tabular}

* - Values in the data denoted with < were valued eaual to the number $(e . g .<2.0-2.0)$. Note: Only 60 samples were used for $\mathrm{SO}_{4}, \mathrm{~S}_{\text {tot }}, \mathrm{S}_{\mathrm{H} 20}, \mathrm{~S}_{i d e}$. 
HANNA NO. I COAL

ANALYTICAL ANALYSIS TRENDS

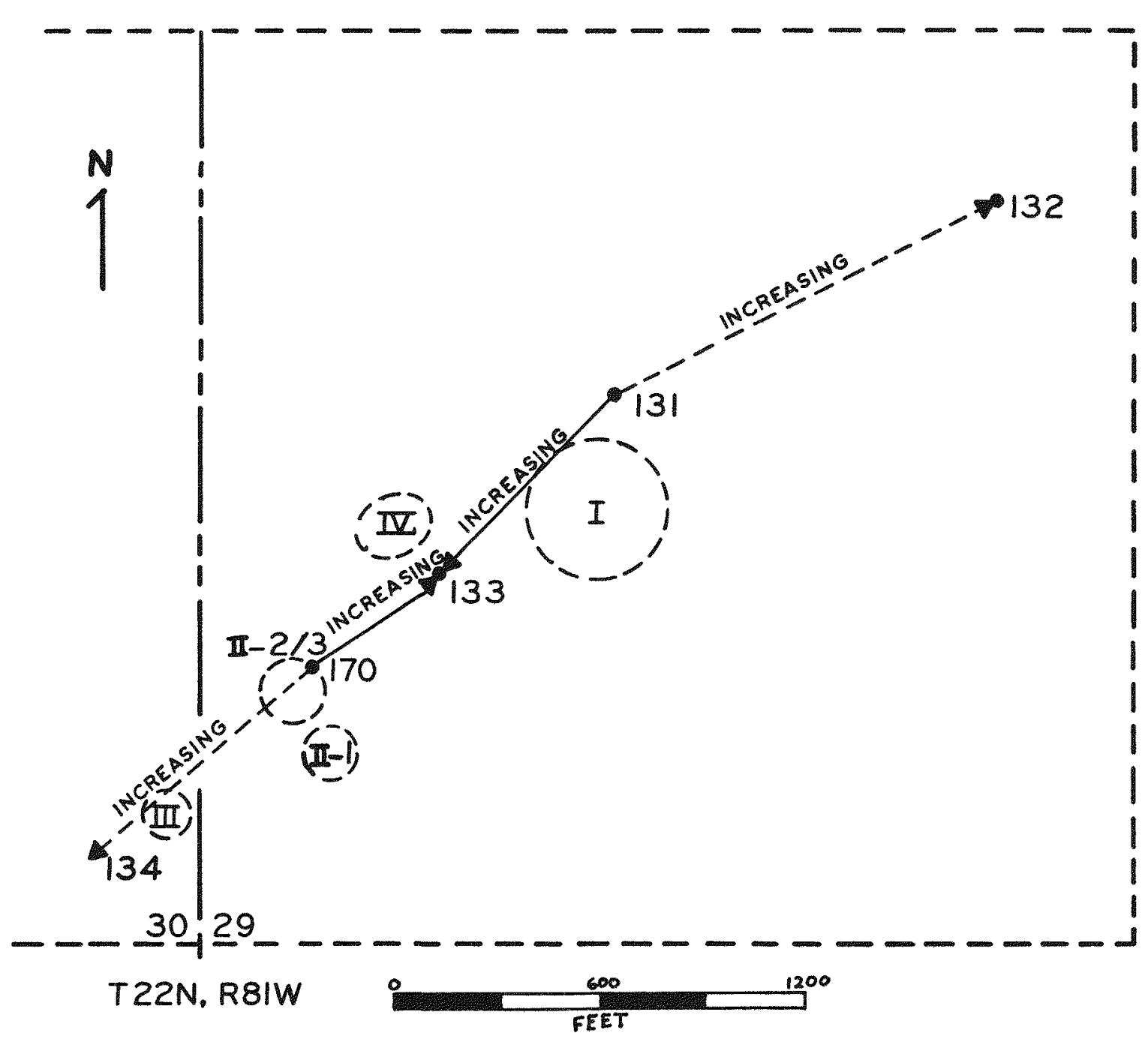

Figure 60. Diagrammatic representation of analytical analysis trend in the Hanna No. 1 coal seam, Hanna UCG site. 
The structure of the Hanna UCG site is characterized by beds dipping gently to the northeast. An east-west fault system near the center of the site interrupts this general trend. This system was found to be a graben complex with numerous antithetic faults (Fig. 9).

The joint sets present in the coal in order of apparent prominance are: 1) $N 60-68^{\mathrm{O}} \mathrm{E}$, 2) $\mathrm{N} 20-30^{\circ} \mathrm{E}$, and 3) $\mathrm{N} 76-85^{\circ} \mathrm{W}$. These sets either strike perpendicularly or parallel to the dominant direction of faulting (Figure 14).

The Hanna Formation above the Hanna No. 1 target coal bed may be divided into four broad local stratigraphic units (from oldest to youngest). 1) Unit A - a Tacustrine delta and Tacustrine deposit; 2) Unit B - a lower meandering river with floodplain deposit; 3) Unit C - a braided river deposit; and 4) Unit D - an upper meandering river with floodplain deposit (Figs. 15 and 20). The Hanna No. 1 coal bed was deposited in a poorly drained swamp environment.

Unit $A$ of the overburden at the Hanna UCG site may be divided into five basic rock types. These are in order of prevalence: 1) calcareous sandstone (72.2 percent), 2) calcareous siltstone (15.1 percent), 3) calcareous shale ( 8.1 percent), 4) ironstone (3.9 percent), and 5) carbonaceous shale $(0.7$ percent). The bulk mineralogy of the overburden is dominated by Quartz (53.1 percent). Other minerals are in the 3-8 percent range and include kaolinite, K-feldspar, dolomite, siderite, plagioclase, mica and calcite. Quartz dominates in all rock types except the ironstone lithofacies which is dominated by siderite $(81.3$ percent).

The sandstones from overburden units $A, B$ and $C$ have distinct compositional and textural characteristics. The lacustrine delta sandstones of Unit A are composed dominantly of quartz and are texturally the most mature. The point bar sandstones of Unit B contain lesser quartz and more lithic fragments and are texturally less mature. The braided river sandstones of Unit $C$ have even less auartz and more lithic fragments and are texturaliy the most immature. These characteristics are indicators of both depositional energy and their proximity to the sediment source.

The proximate analysis of 176 samples of the Hanna No. 1 coal bed shows the average ash content is 27.4 percent, average moisture is 8.4 percent, average volatile matter is 32.7 percent, and the average fixed carbon content is 31.5 percent.

Minerals present in the coal ash in order of abundance are kaolinite $(23.5$ percent), $i 17 i$ te $(22.6$ percent), quartz ( 18.1 percent), kfeldspar ( 3.1 percent), gypsum (2.9 percent), aragonite ( 2.0 percent), siderite ( 1.5 percent), calcite $(1.4$ percent), pyrite $(0.8$ percent), plagioclase $(0.8$ percent), rutile $(0.5$ percent), and goethite $(0.2$ percent). 22.6 percent of the minerals in ash were amorphous or unidentified. A table showing the elemental analysis of the coal is provided. 
The forms of sulfur in the coal are organic (0.44 percent), pyritic (0.19 percent), and sulfate (0.01 percent). Seven types of pyrite were identified and include in order of abundance: dispersed euhedra, clustered euhedra, irregular, blebs, fracture filling, framboids, and dendritic.

A maceral analysis was done on the coal with vitrinite being the most abundant followed by exinite and inertinite respectively. Maceral types present include vitrinite (90.3 percent), pseudovitrinite ( 1.5 percent), exinite ( 5.5 percent), resinite $(0.6$ percent), semi-fusinite ( 1.0 percent), semi-macrinite $(0.1$ percent), fusinite $(0.3$ percent), macrinite $(0.1$ percent), micrinite $(0.5$ percent), and sclerotinite $(0.1$ percent). The classification of Hanna coals fall predominantiy into the bituminous high volatile $C$ class using ASTM, mean-maximum vitrinite reflectance, and percent ash methods.

Semi-quantitative spectrographic and analytic geochemical analyses were done on the overburden rocks and coal. Six correlative relationships were established for the element concentrations of the semiquantitative spectrographic analysis for the local overburden units and the coal. 1) The total average overburden values are dominantly higher than the values for the total average coal probably due to a higher percentage of carbon in coal than silica in the overburden rocks. 2) The total average concentration values in Unit $A$ are generally higher than Unit $B$ followed by Unit $D$ and Unit $C$ due to percentage of sandstone in the Unit. Therefore, Unit $C$ (lowest concentration values) has the highest sandstone percentage followed by Unit $D$, Unit $B$ and Unit $A$ (highest concentration values) with the lowest sandstone percentage. 3) The element concentration trends for the Hanna No. 1 coal from hole to hole show an increase from the middle outward. Perhaps this direction of increase is towards the swamp margins where more impurities would be expected. 4) Unit A increases concentration values towards the northeast which is towards the delta front of the Tacustrine delta. Unit $B$ trends are very similar to that of the Hanna No. 1 coal and represents an increase in element concentrations away from the channel or towards the floodplain. Unit $C$, like Unit $A$, also represents an increase in element concentrations towards the northeast which is towards the thickest deposits of the braided stream where the presence of more lithic fragments is expected. No trend was established for Unit D. 5) The trend of local stratigraphic units within each hole is essentially identical to the trend described in \#2 above, that is highest concentrations in Units $A$ and $B$ followed by Unit $D$ and Unit $C$ respectively. 6) The relationship of concentration values in the coal as compared to the total overburden from hole to hole was very similar to that shown in \#1 above, that is lower concentrations for the coal.

The spectrographic analysis was also done by lithotype, with the mudstones and shales lithotype having the highest average element concentrations followed by the siltstones and silty sandstones 7 ithotype and the sandstones and conglomerates lithotype respectively. The proposed inverse relationship of element concentrations to percentage of sandstone in the overburden units is well supported by this analysis. 
The analytical analysis was done by stratigraphic unit. The coal, as expected, was highest in $\mathrm{Li}, \mathrm{P}, \mathrm{SO}_{4}, \mathrm{~S}($ tot $)$ and $\mathrm{S}(\mathrm{H} 2 \mathrm{O})$. It was lowest in $\mathrm{Al}, \mathrm{Mg}, \mathrm{K}, \mathrm{Rb}, \mathrm{Si}$, and Sulfide due to the low content of feldspars and quartz minerals as compared to the overburden units. Among the overburden units, Unit $A$ was highest in $\mathrm{Mg}, \mathrm{P}, \mathrm{Rb}$ and the sulfurs and lowest in $A 7, L i$ and $S i$ due to a higher percentage of siltstones and 'dirty' sandstones as compared to Units B and C. Unit B was highest in $A l$ and showed middle values for the other elements due to a higher percentage of shales and mudstones in the unit as compared with Units $A$ and $C$. Unit $C$ was highest in $\mathrm{Li}, \mathrm{K}$, Si, and $\mathrm{Na}$ and was lowest in $A 7, \mathrm{Mg}, P$ and the sulfurs due to the very high sand content of this unit with practically no siltstones or shales to add $\mathrm{Al}, \mathrm{Mg}, \mathrm{P}$ and $\mathrm{S}$. No data on Unit $D$ was available. The average baseline values of the Hanna No. 1 coal bed were calculated from 124 samples from five coreholes. 


\section{REFERENCES}

Ammosov, I. I., and Eremin, I. V., 1963, Fracturing in coal: Israel Program for Scientific Translations, Ltd., 112 p.

Berkman, E., and Orange, A., 1983, High resolution seismic survey of the Hanna, Wyoming, underground coal gasification area: DOE/Contract Report \#DE-AC20-83LC70977.

Blackstone, D. L., 1975, Late Cretaceous and Cenozoic history of Laramie Basin region, southeast Wyoming: Geol. Soc. America, Memoir 144, pp. 249-279.

Bowen, C. F., 1918, Stratigraphy of the Hanna Basin, Wyoming: U.S. Geo1. Survey Prof. Paper 108-L, pp. 227-235.

Brandenburg, C. F., Fischer, D. D., Northrop, D. A., and Schrider, L. A., 1976, Results and status of the second Hanna in situ coal gasification experiment: Proc. Second Underground Coal Conversion Symposium, pp. 36-52.

Brandenburg, C. F., Fischer, D. D., Boyd, R. M., King, S. B., and Humphrey, A. E., 1977, A review of LERC's in situ coal gasification project: Proc. Third Underground Coal Conversion Symposium, pp. 6676.

Brandenburg, C. F., 1979, Field implementation of UCC research: Proc. Fifth Underground Coal Conversion Symposium, pp. 11-23.

Brooks, K. J., 1977, Petrology and depositional environments of the Hanna Formation in the Carbon Basin, Carbon County, Wyoming:

Unpublished M. S. Thesis, University of Wyoming, $105 \mathrm{p}$.

Burns, L. K., Craig, G. N., II, Ethridge, G. F., and Youngberg, A. D., 1981, Pyrometamorphism caused by the Hanna II, Phases 2 and 3 , underground coal gasification experiment: Proc. Seventh Underground Coal Conversion Symposium, pp. 361-370.

Burns, L. K., Craig, G. N., II, Alexander, W. G., Ethridge, F. G., and Youngberg, A. D., 1982, The application of geological and mineralogical studies to underground coal gasification technology: Proc. Eighth Underground Coal Conversion Symposium, pp. 553-556.

Colorado School of Mines Research Institute, and Engineering Enterprises, Inc., 1979, Use of mineralogy in predicting possible groundwater chemical changes resulting from in situ gasification of coal -- preliminary study: Environmental Protection Agency Project C80415.

Craig, G. N., Burns, L. K., Ethridge, F. G., Laughter, T. F., and Youngberg, A. D., 1982, Overburden characterization and post burn study at the Hanna, Wyoming, underground coal gasification site: stratigraphy, depositional environments and mineralogy, Hanna Formation: DOE/LC/10496-TI (DE82009053). 
Craig, G. N., 1982, Depositional environments and petrology of the Hanna Formation, Hanna UCG site, Wyoming: Unpublished M. S. Thesis, Colorado State University, $175 \mathrm{p}$.

Davis, A., 1978, The reflectance of coal: in C. Karr, Analytical Methods for Coal and Coal Products, v. 1, pp. 27-81.

Dobbin, C. E., Bowan, C. D., and Hoots, H. W., 1929, Geology and coal and oil resources of the Hanna and Carbon Basins, Carbon County, Wyoming: U.S. Geological Survey Bulletin $804,88 \mathrm{p}$.

Fischer, D. D., Brandenburg, C. F., King, B. S., Boyd, R. M., and Hutchinson, H. L., 1976, Status of the linked vertical we 11 process in underground coal gasification: Proc. Second Underground Coal Conversion Symposium, pp. 354-371.

Fischer, D. D., King, S. B., and Humphrey, A. E., 1977, A report on the successful development of underground coal gasification at Hanna, Wyoming: Proc. Second Joint Canadian Inst. of Chemistry and American Chemical Society Conference, Montrea1, Quebec, Canada.

Fischer, D. D., Boysen, J. E., and Gunn, R. D., 1977, Energy balance for the second underground coal gasification experiment, Hanna, Wyoming: SME Trans., v. 262, No. 4, pp. 341-348.

Glass, G. B., 1972, Mining in the Hanna coal field: Geological Survey of Wyoming, Miscellaneous Report, $45 \mathrm{p}$.

Glass, G. B., and Roberts, J. T, , 1980, Coals and coal-bearing rocks of the Hanna coal field, Wyoming: the Geological Survey of Wyoming, Rept. of Invest., No. 22,43 p.

Knight, S. H., 1961, Late Cretaceous-Tertiary history of the northern portion of the Hanna Basin, Carbon County, Wyoming: Wyoming Geol. Assoc. Guidebook, 16th Ann. Field Conf., pp. 155-164.

Krauskopf, K. B., 1979, Introduction to geochemistry; Second Edition: McGraw-Hi11 Book Company, New York, $617 \mathrm{p}$.

Levie, B. E., Krantz, W. B., Camp, D. W., Gunn, R. D., Youngberg, A. D., 1981, Application of the spalling-enhanced-drying model in predicting cavity geometry and operating strategy for the Hanna 2, Phase 2 UCG field test: Proc. Seventh Underground Coal Conversion Symposium, pp. 236-245.

Nickelson, R. P., and Hough, V. D., 1967, Jointing in the Applachian Plateau of Pennsylvania: Geological Society of America Bull., v. 78, p. $609-630$.

Pasini, J., III, Overbey, W. K., and Komar, C. A., 1972, Directional properties of Hanna coal, fanna Coal Field, Wyoming: Morgantown Energy Research Center, Technical Report, December. 
Ryan, J. D., 1977, Late Cretaceous and early Tertiary provenance and sediment dispersa1, Hanna and Carbon Basins, Carbon County, Wyoming: Pre1. Rept. No. 16, Geological Survey of Wyoming, $17 \mathrm{p}$.

Surdam, R. C., and Stanley, K. 0., 1978, Sedimentation on the front of Eocene Gilbert-type deltas, Washakie Basin, Wyoming: Journal of Sedimentary Petrology, v. 48, pp. 557-573.

Walker, R. G., and Cant, D. J., 1979, Facies models: sandy fluvial systems: In R. G. Walker (ed), Facies Models, Geoscience Canada Reprint Series 1, pp. 23-31.

Youngberg, A. D., and Sinks, D. J., 1981, Post burn study results for Hanna II, Phases 2 and 3 underground coal gasification experiment: Proc. Seventh Underground Coal Conversion Symposium, pp. 18-28.

Youngberg, A. D., 1981, Petrographic analysis of unaltered and thermally metamorphosed coal from the Hanna, Wyoming, gasification area:

Proc. Seventh Underground Coal Conversion Symposium, pp. 402-475.

Youngberg, A.D., Berkman, E., and Orange, A., 1982, Location of burns and faults at the Hanna underground coal gasification area using high resolution seismic: Proc. Seventh Underground Coal Conversion symposium, pp. 703-717.

Youngberg, A. D., Berkman, E., and Orange, A., 1982, High resolution seismic survey of the Hanna, Wyoming, underground coal gasification area: Laramie Energy Technology Center, Rept. Invest. 82-1, 45 p.

Youngberg, A. D., MCClurg, J. E., and Schmitt, J. G., 1983, Depositiona1 environments, subsurface stratigraphy, and post burn characterization of the Paleocene-Eocene Hanna Formation at the Hanna, Wyoming underground coal gasification site: Hanna II, Phase 1 experiment: Laramie Energy Technology Center, Rept. Invest. 83-2, 163 p.

Youngberg, A. D., McClurg, J. E., and Schmitt, J. G., 1983, Depositional environments, subsurface stratigraphy, and post burn characterization of the Paleocene-Eocene Hanna Formation at the Hanna, Wyoming, underground coal gasification site: Hanna III Experiment: Laramie Energy Technology Center, Rept. Invest. 83-1, 120 p. 


\begin{abstract}
APPENDIX A
Depth Intervals from Geophysical Logs of Local

Stratigraphic Units at the Hanna UCG Site Area
\end{abstract}




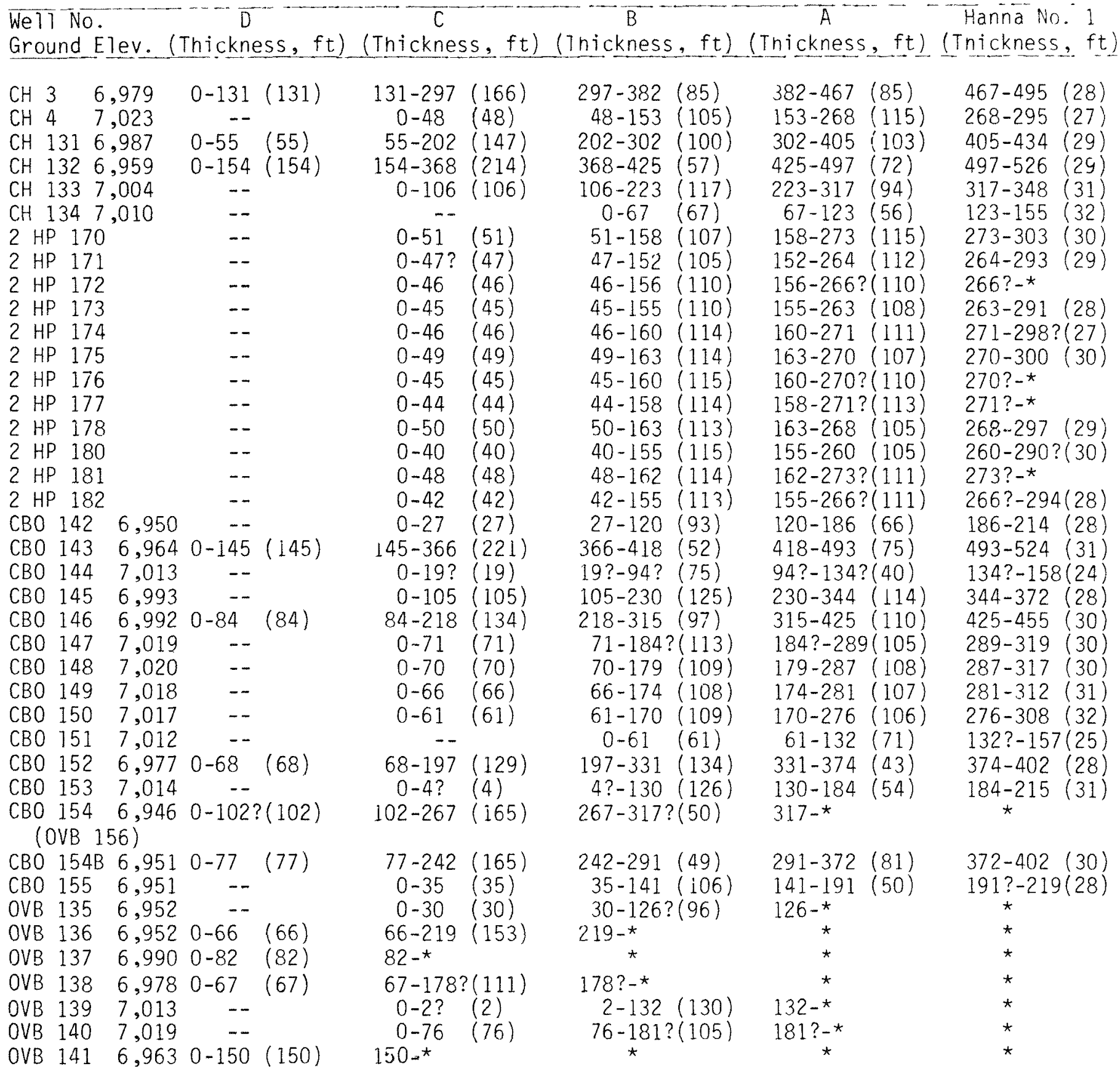

? - pick is appro,imate or indistinct; * - insufficient TD

NOTE: Exact footage may not correlate from logs to cores. Picks for UP wells are from driller's logs. 


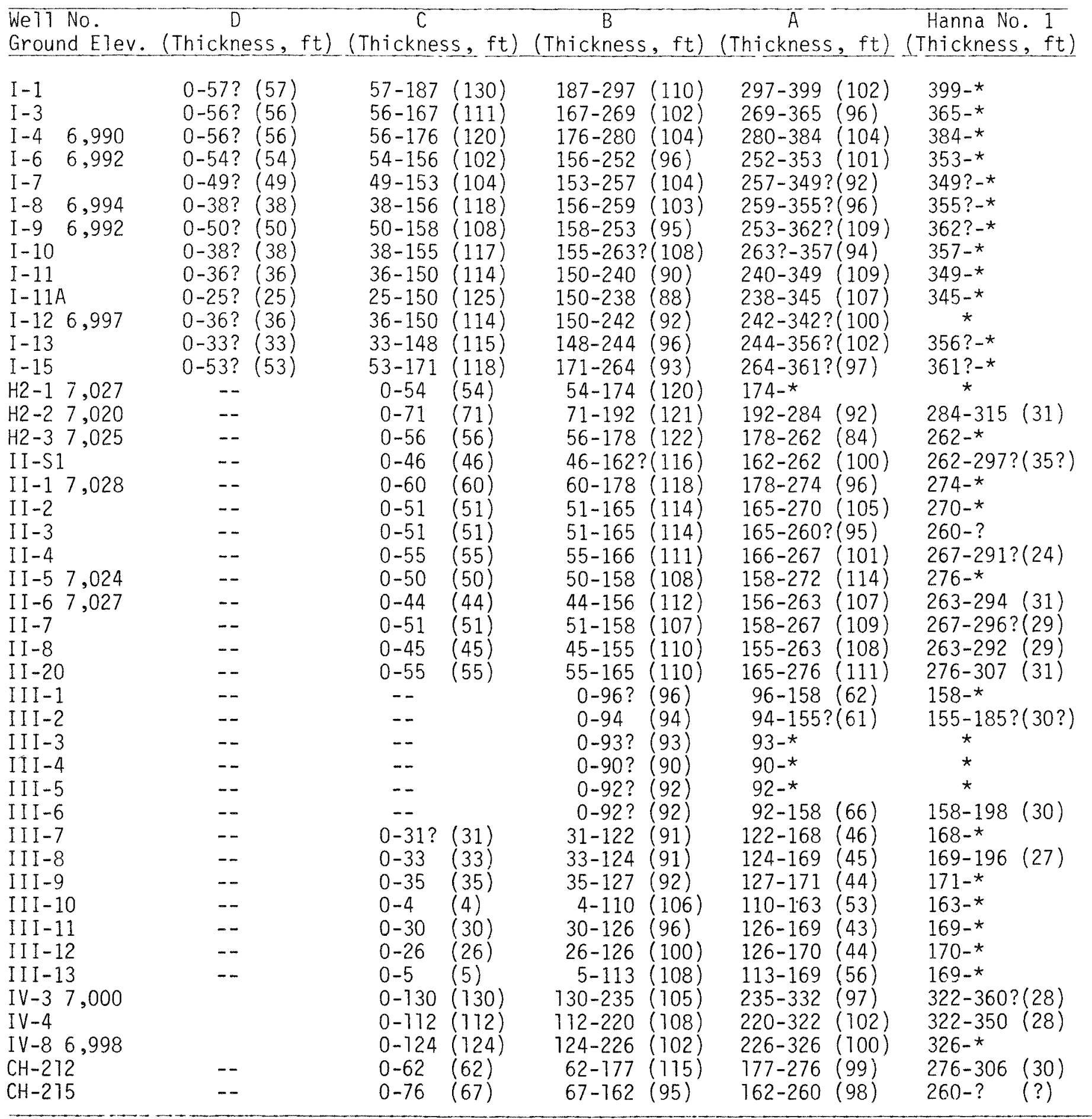




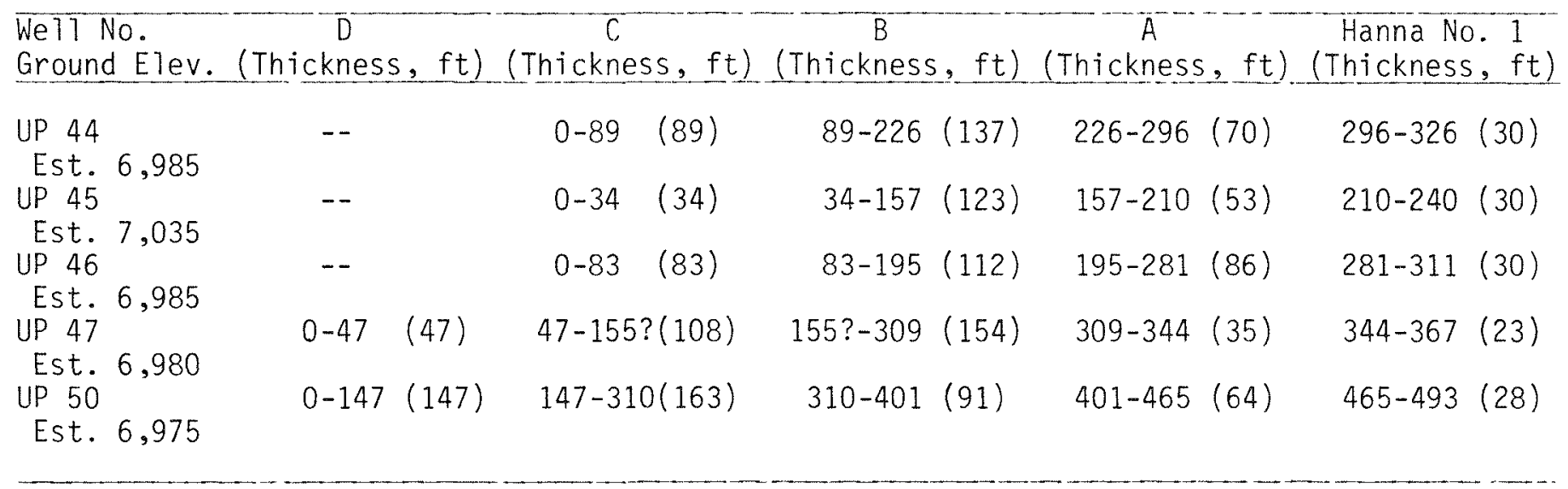




\section{APPENDIX B}

Element and Ash Concentration Profiles of the Hanna No. 1

Coal Bed for $\mathrm{CH}-133$, Hanna UCG Site 


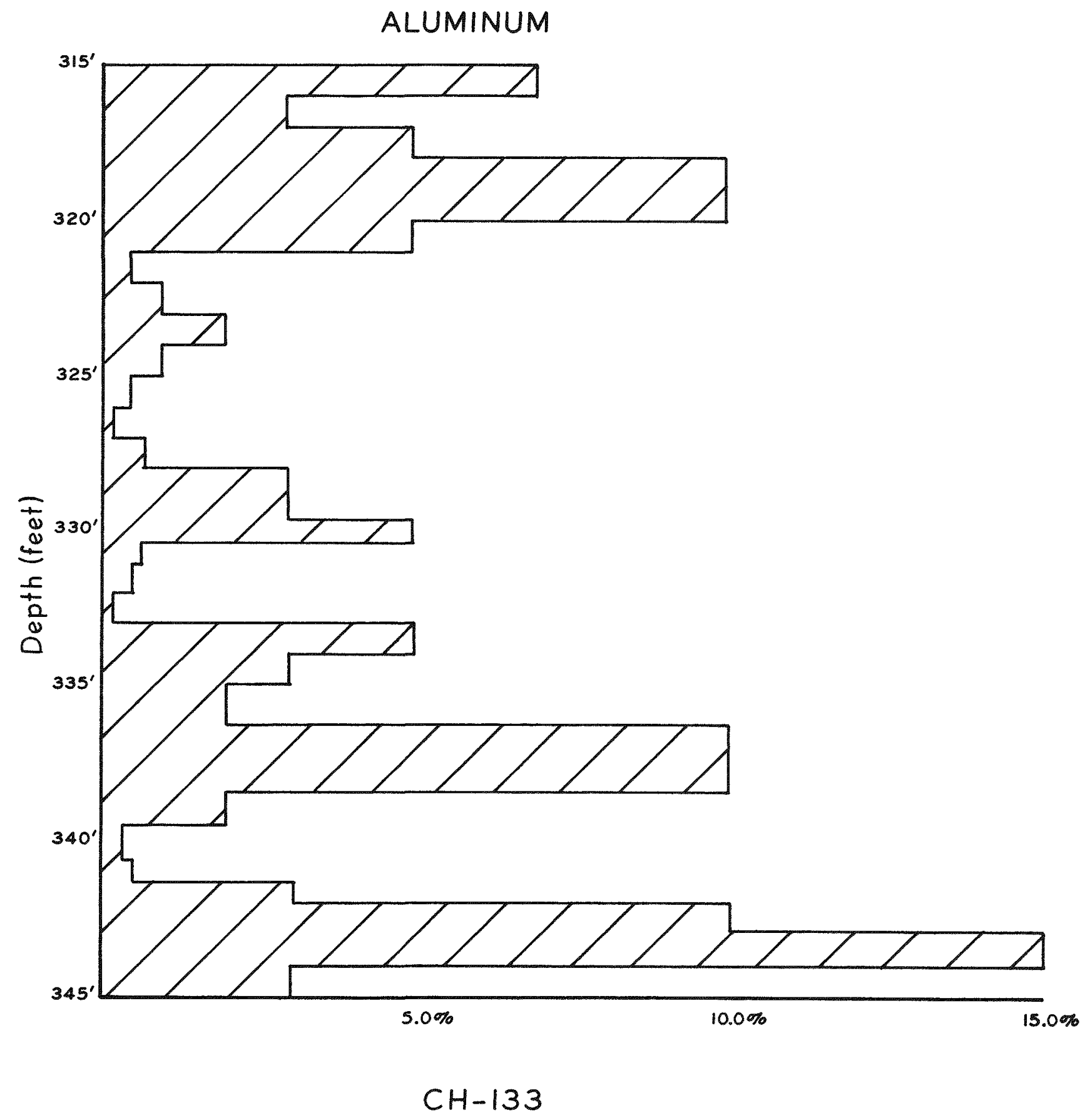




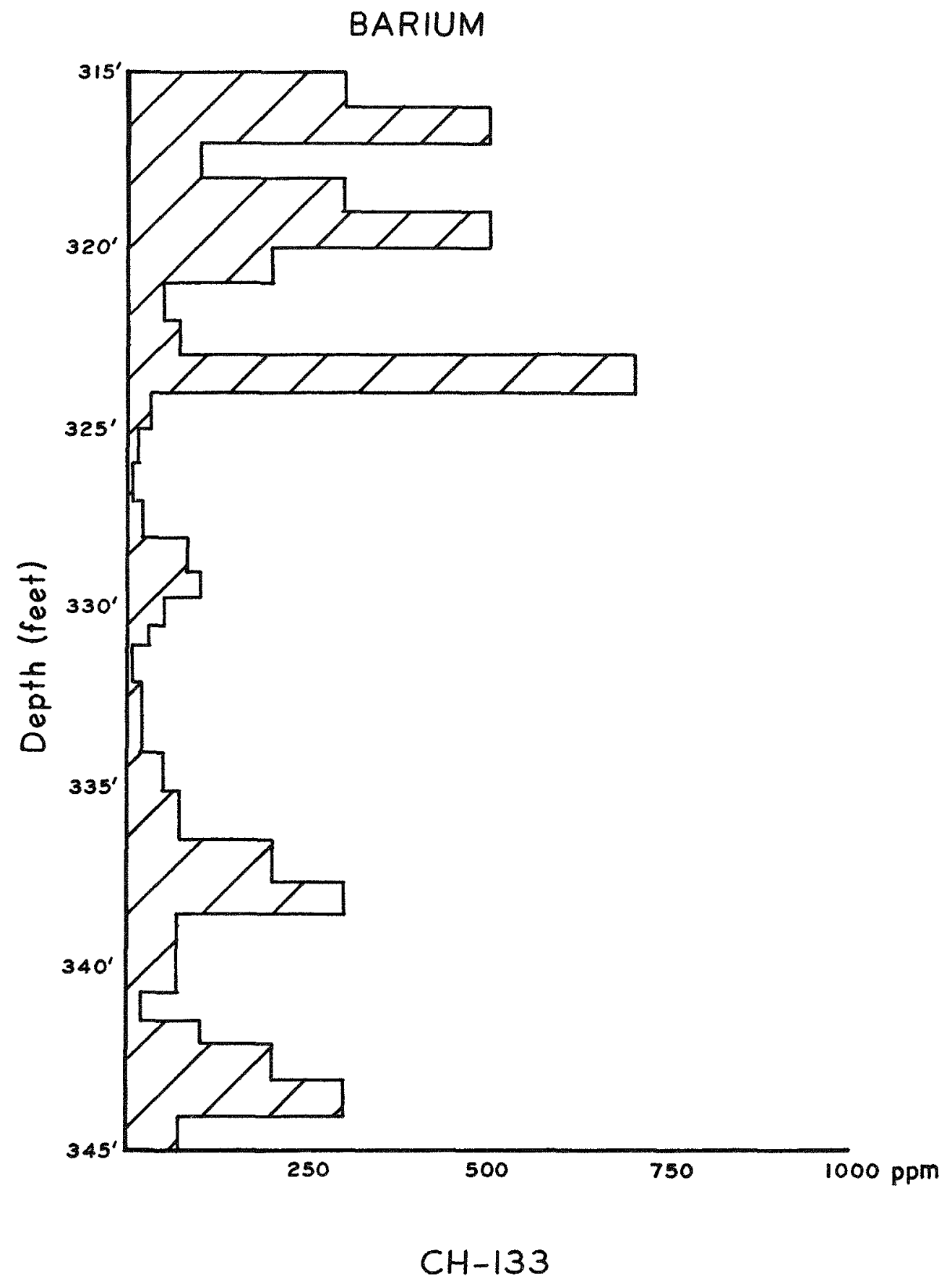




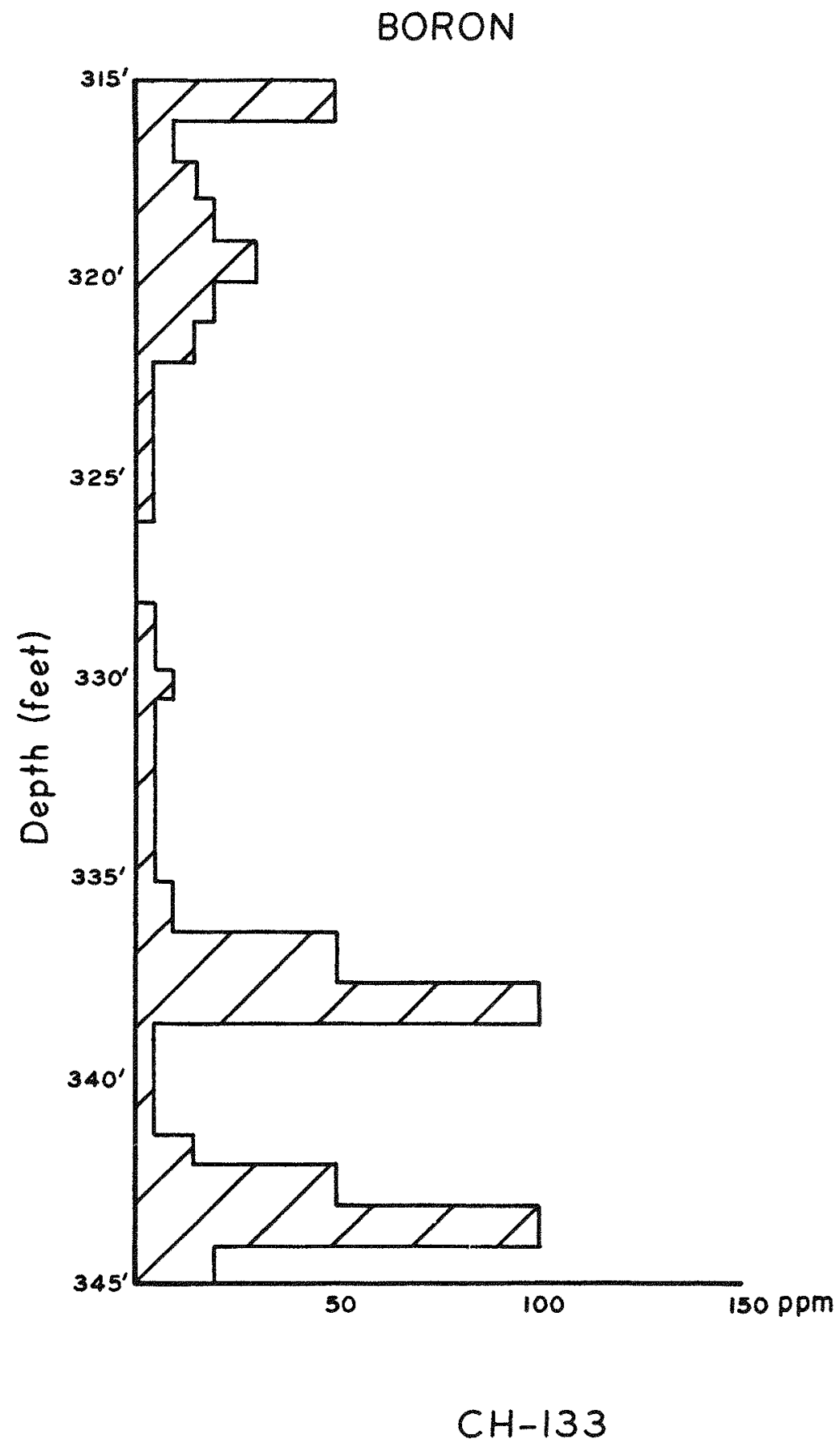




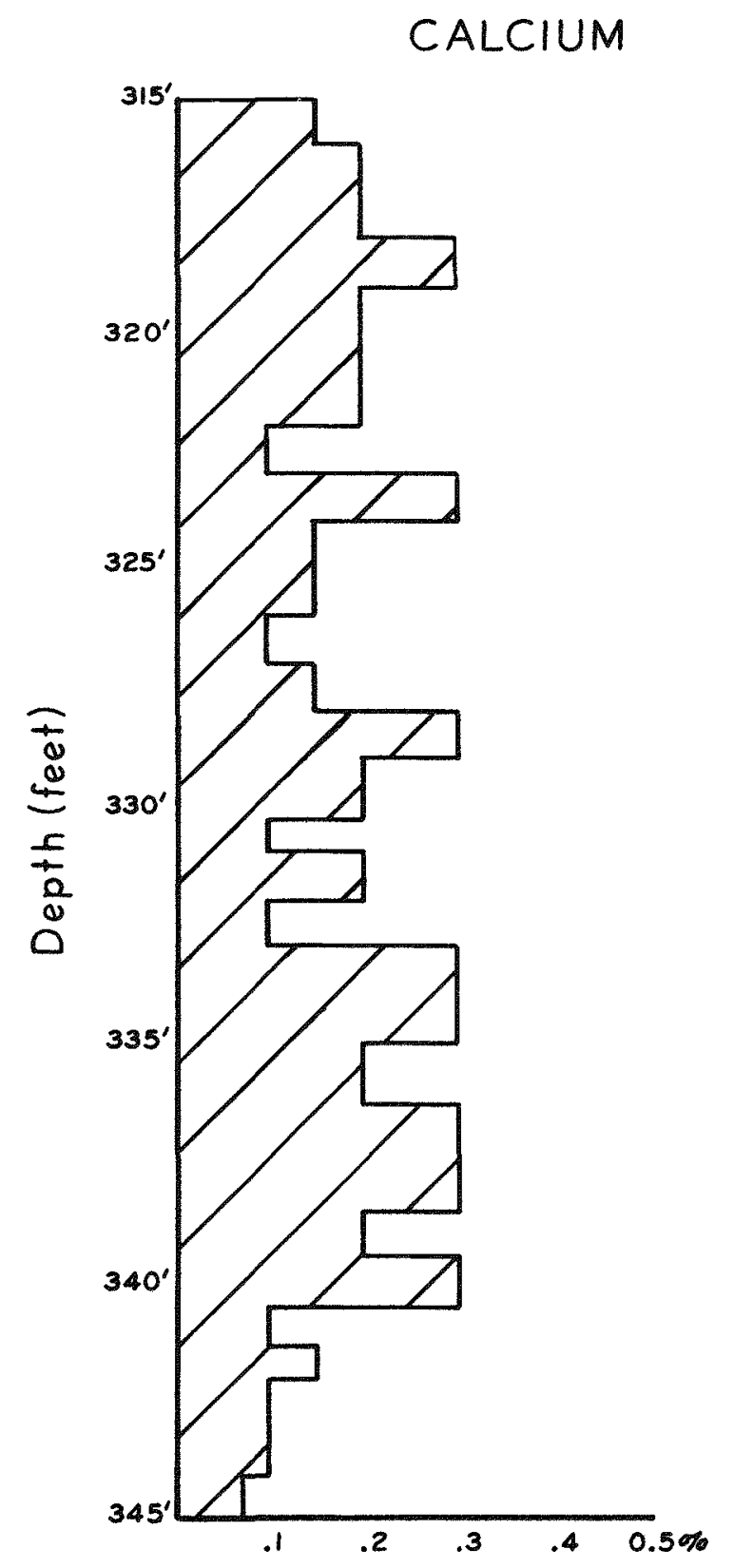

$\mathrm{CH}-133$ 


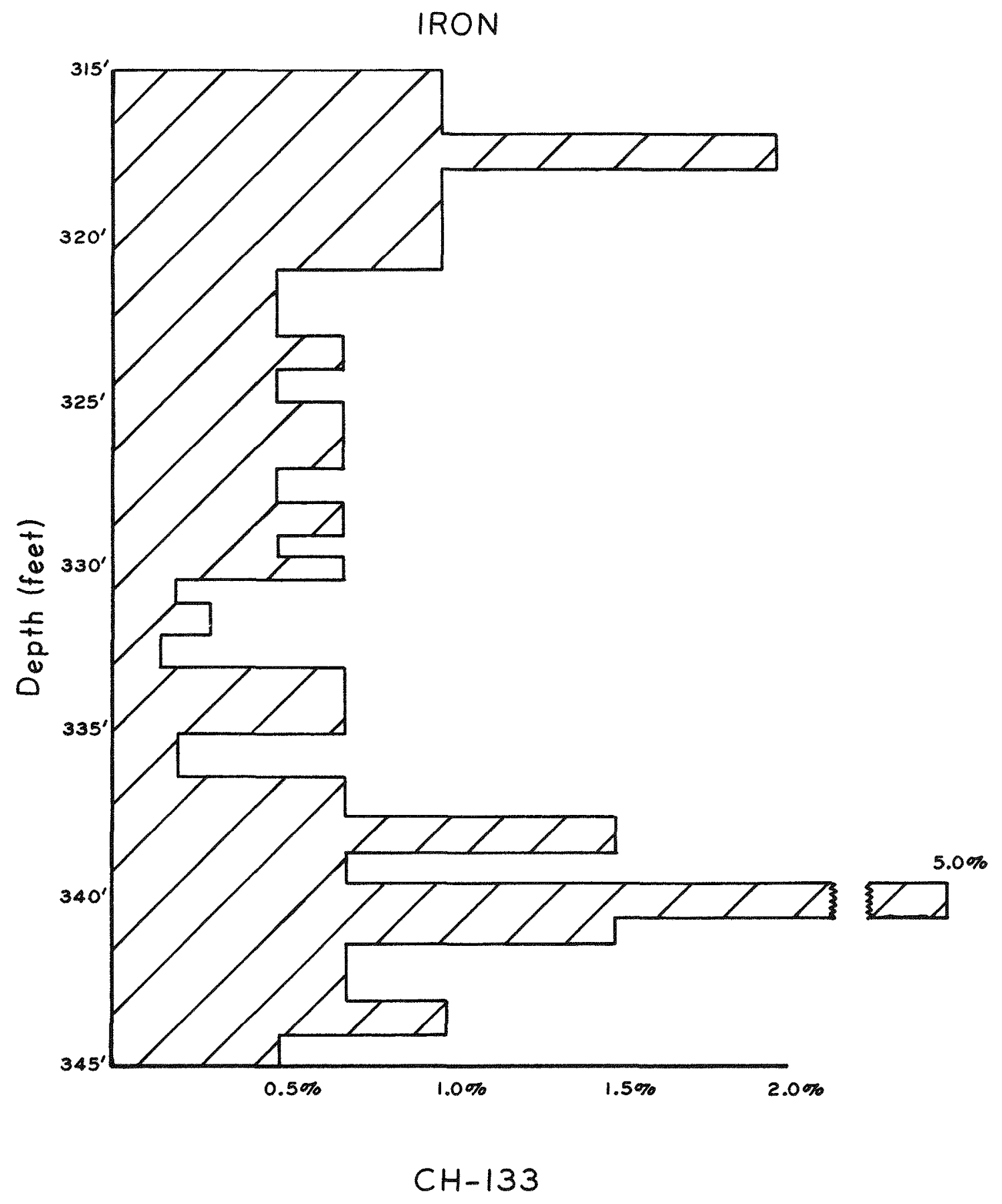




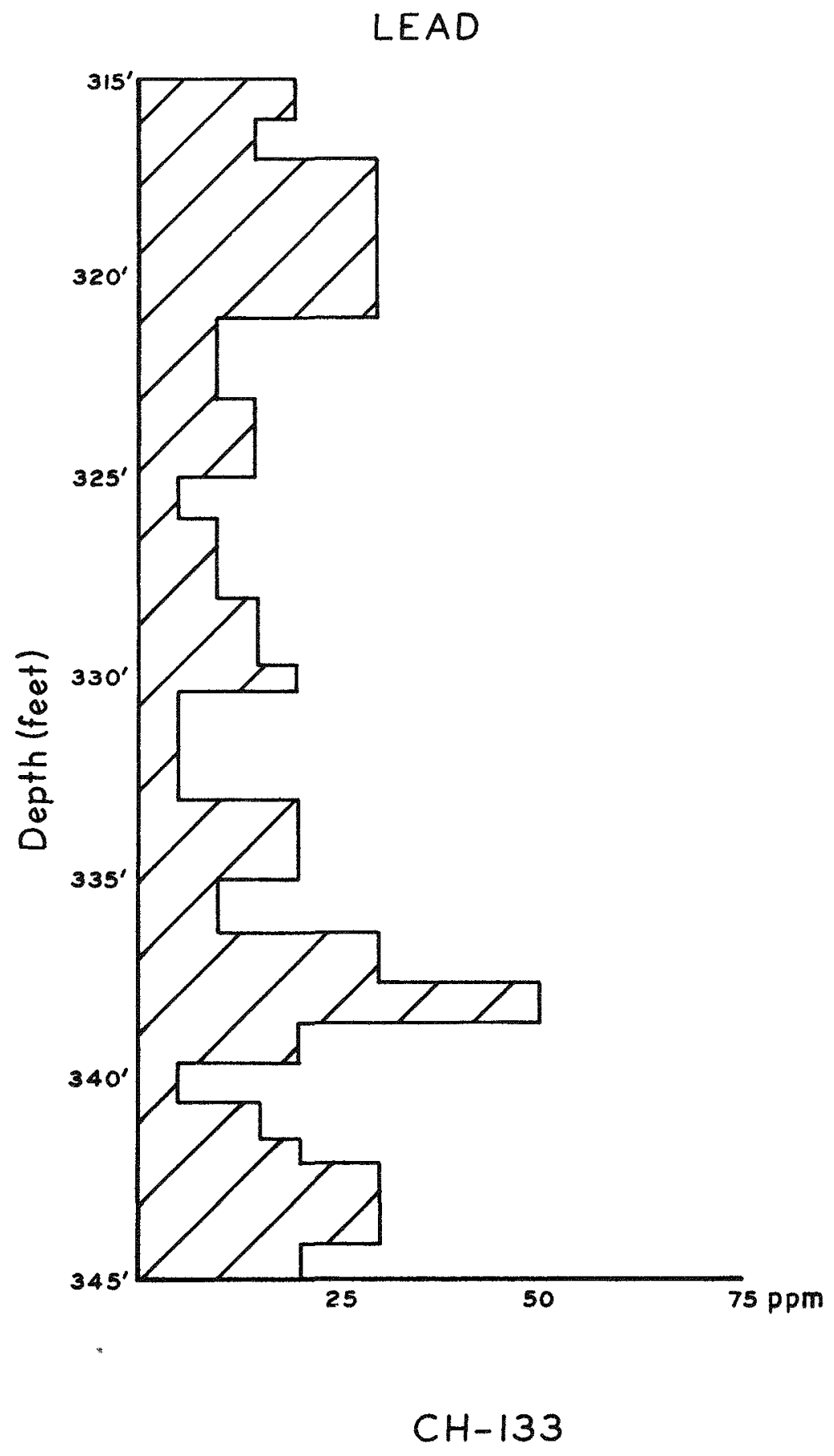




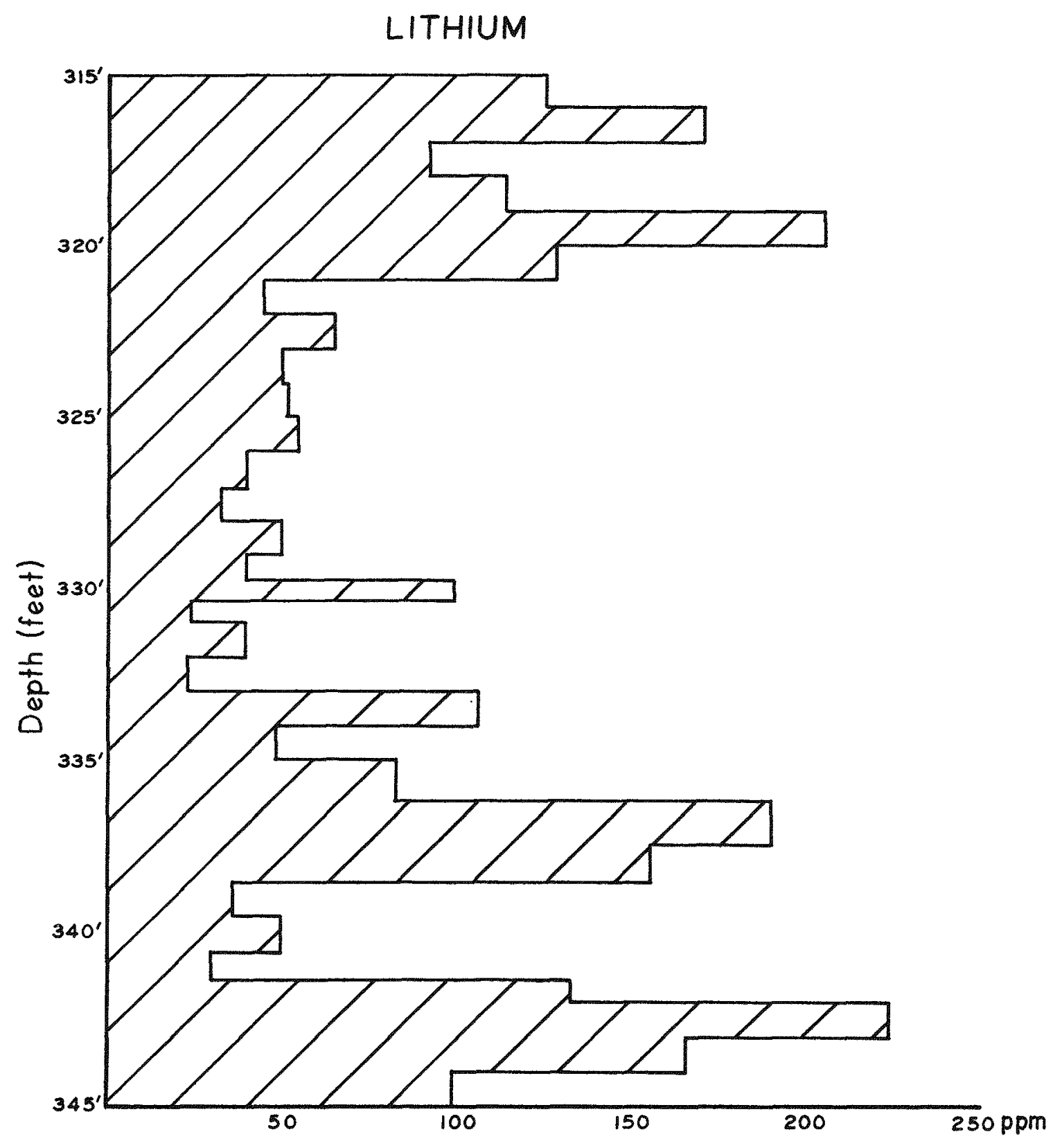

$\mathrm{CH}-133$ 


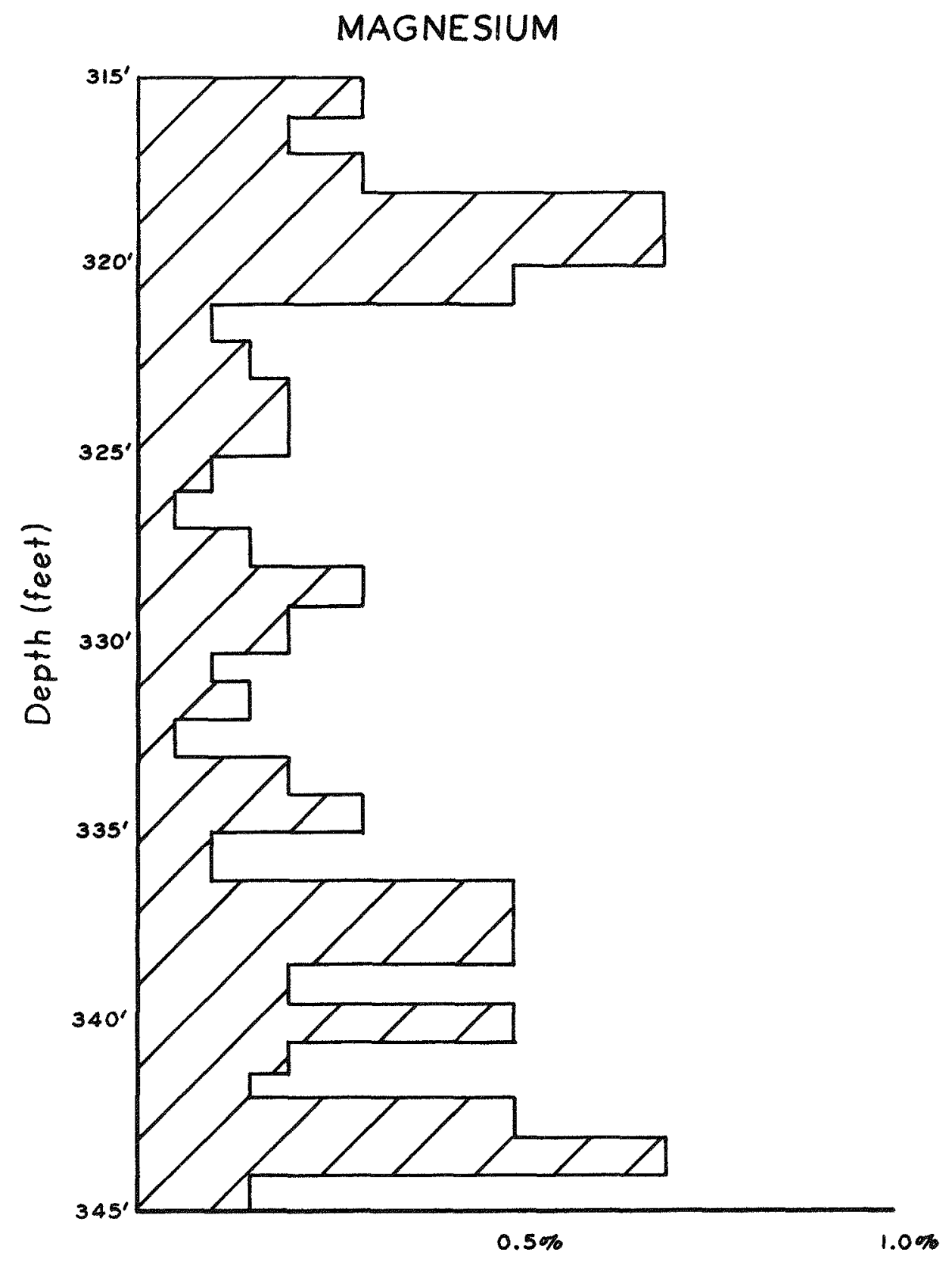

$\mathrm{CH}-133$ 


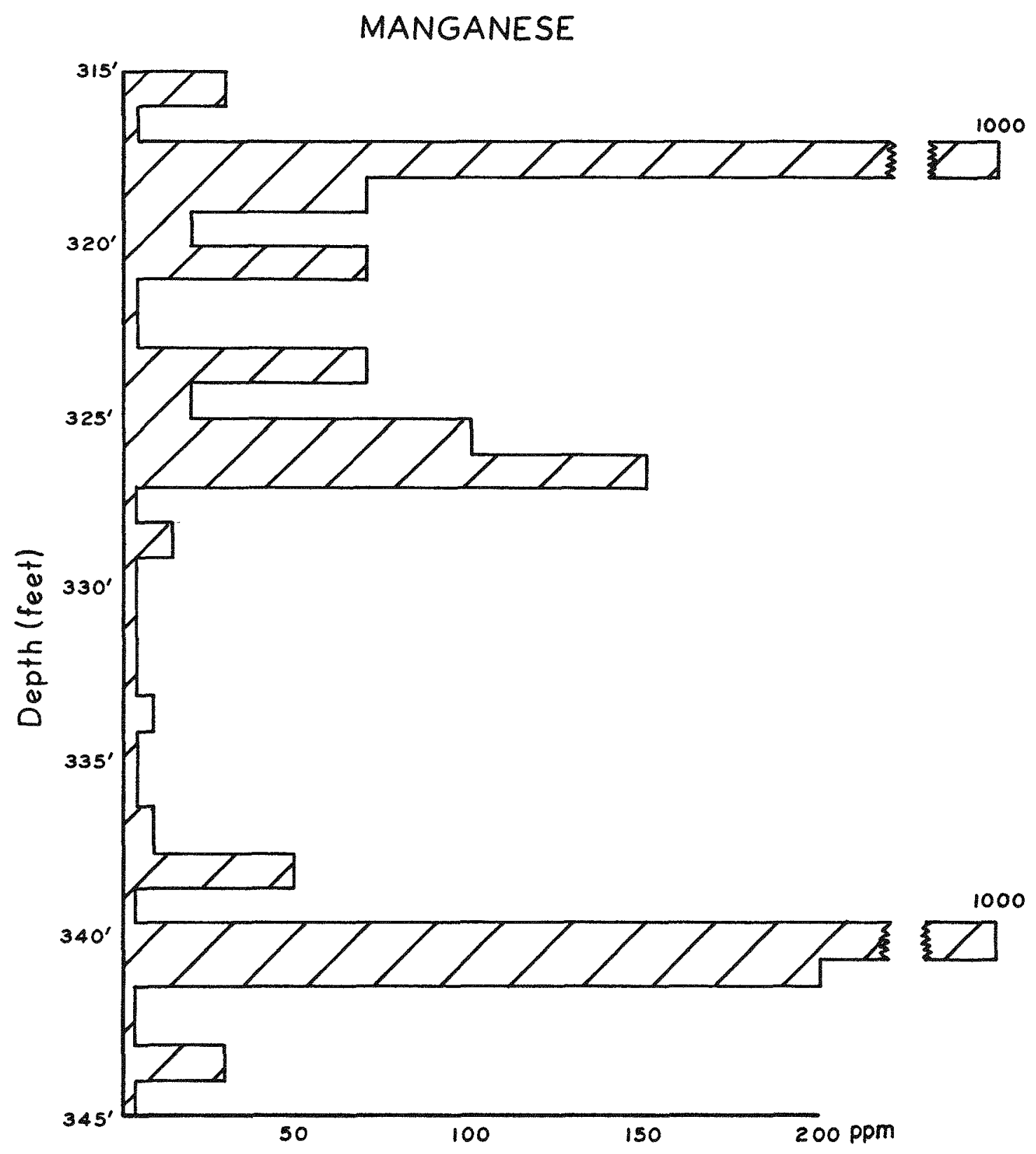

$\mathrm{CH}-133$ 


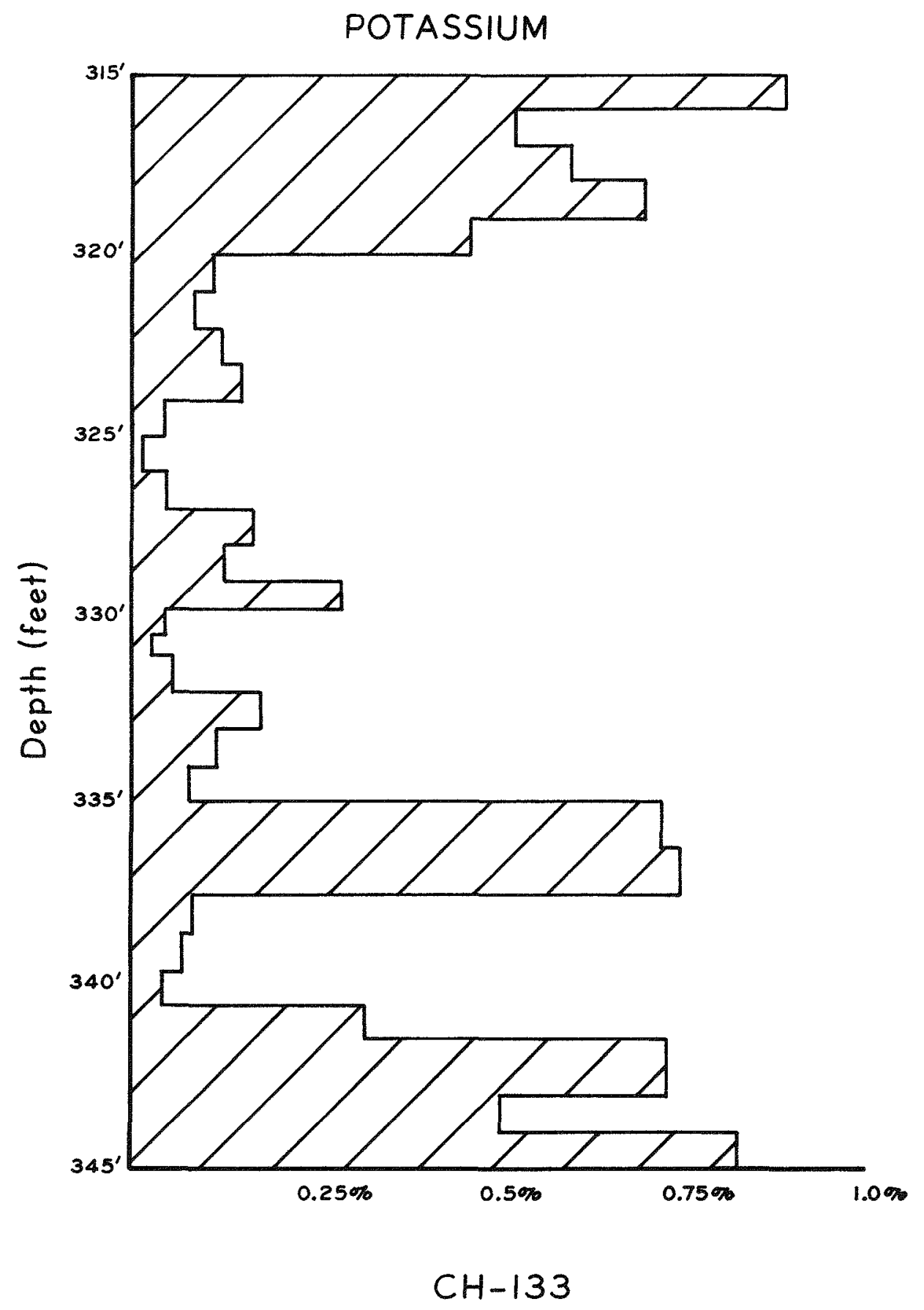




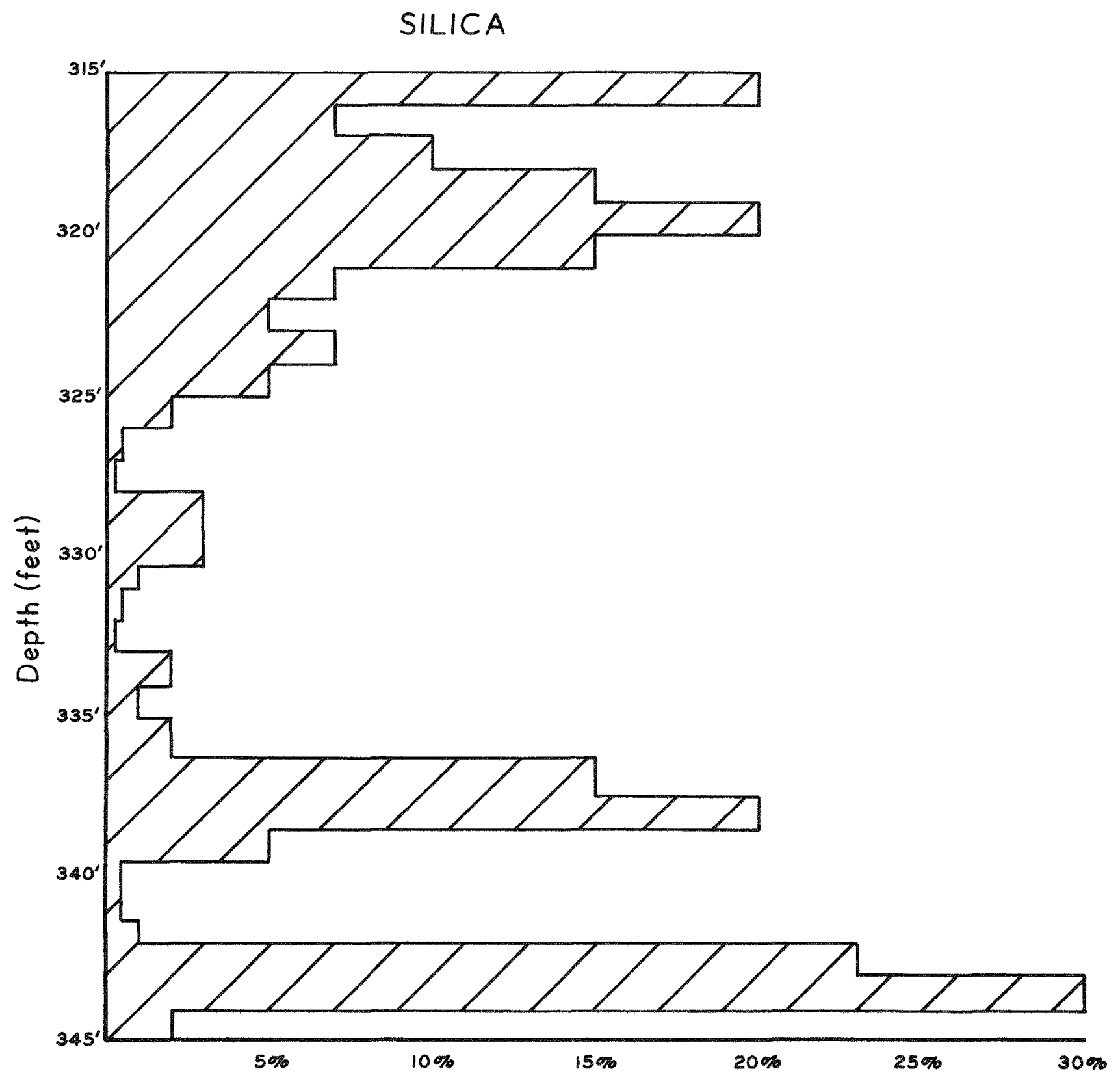

$\mathrm{CH}-133$ 


\section{SODIUM}

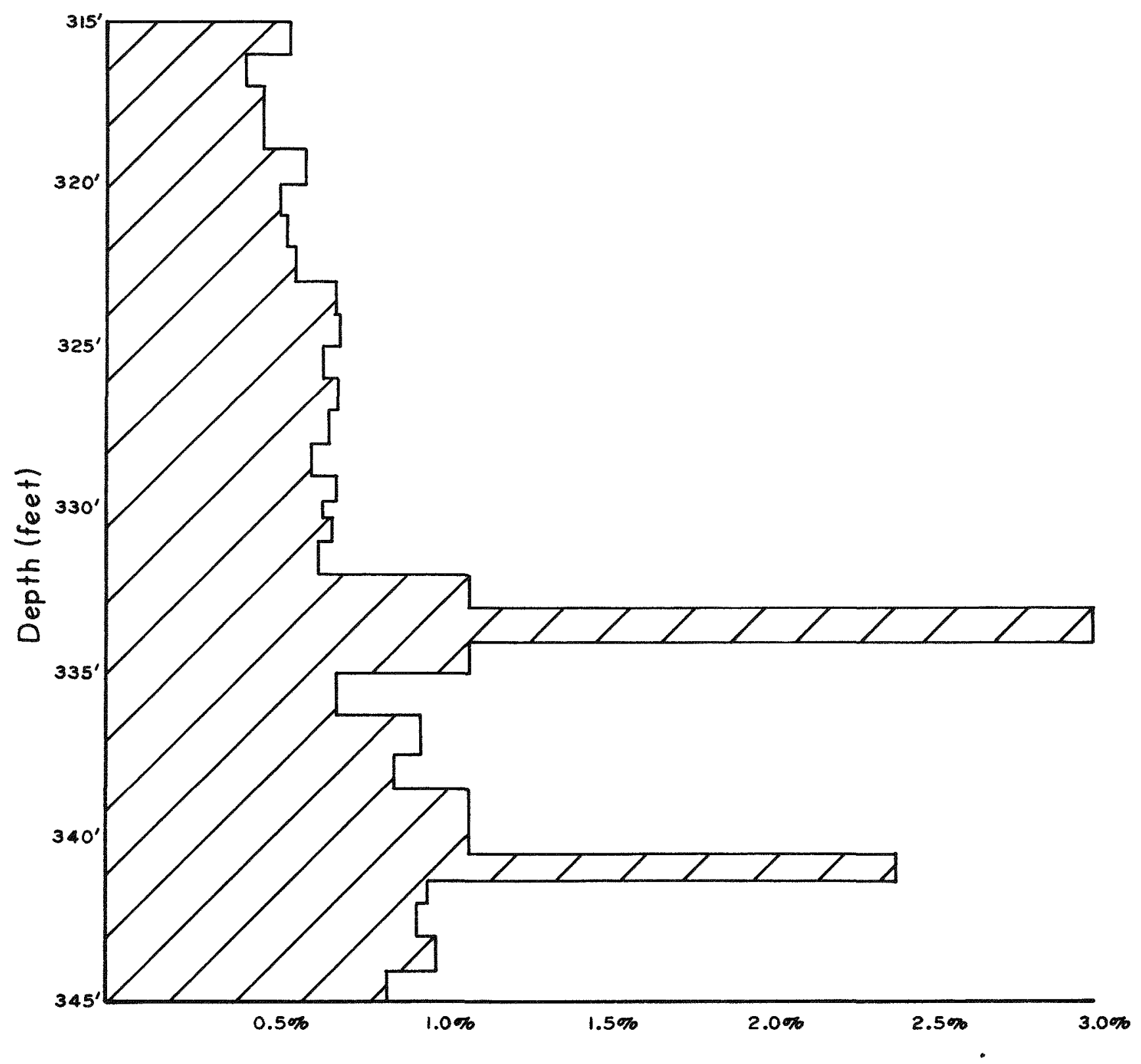

$\mathrm{CH}-133$ 


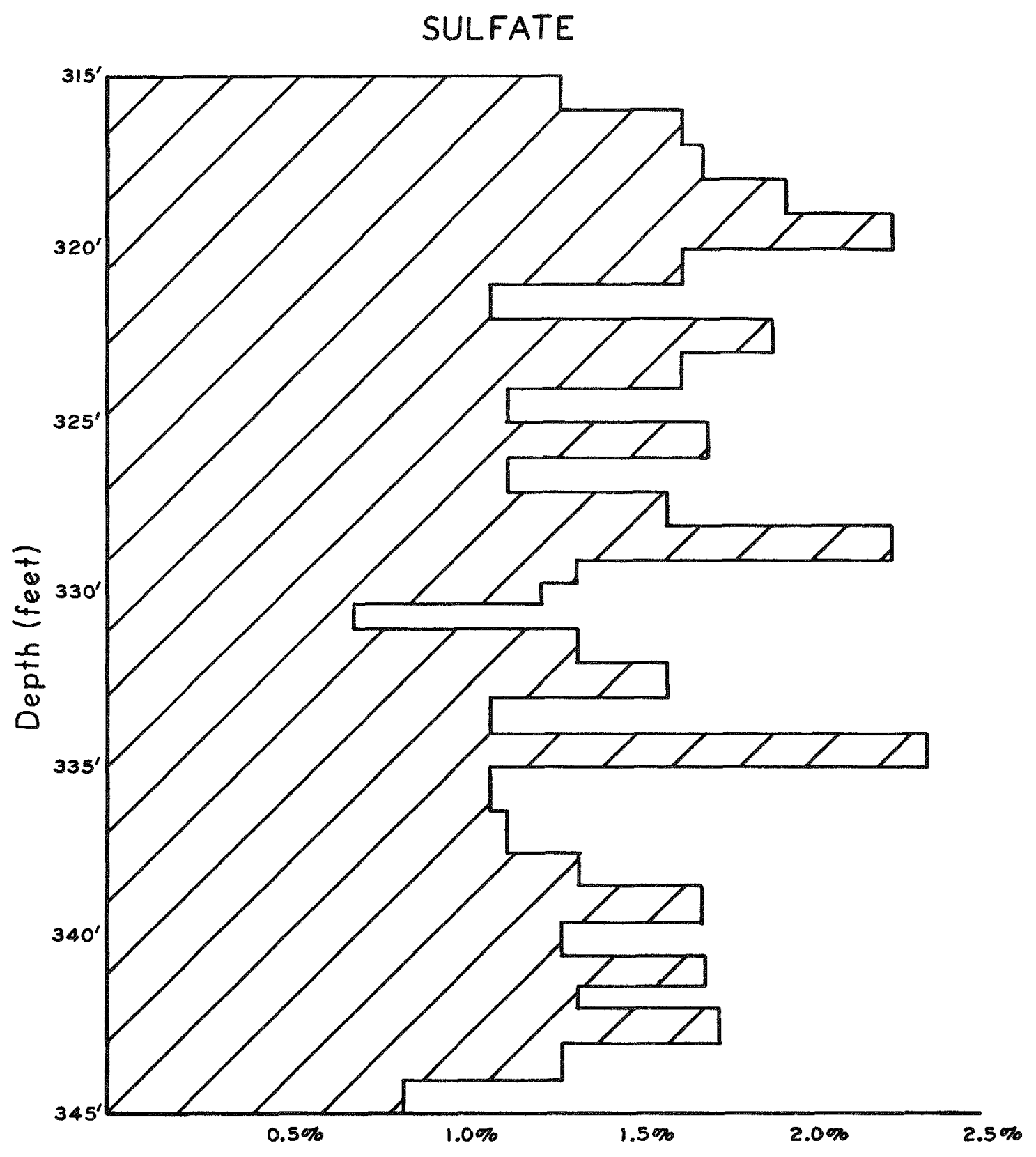

$\mathrm{CH}-133$ 


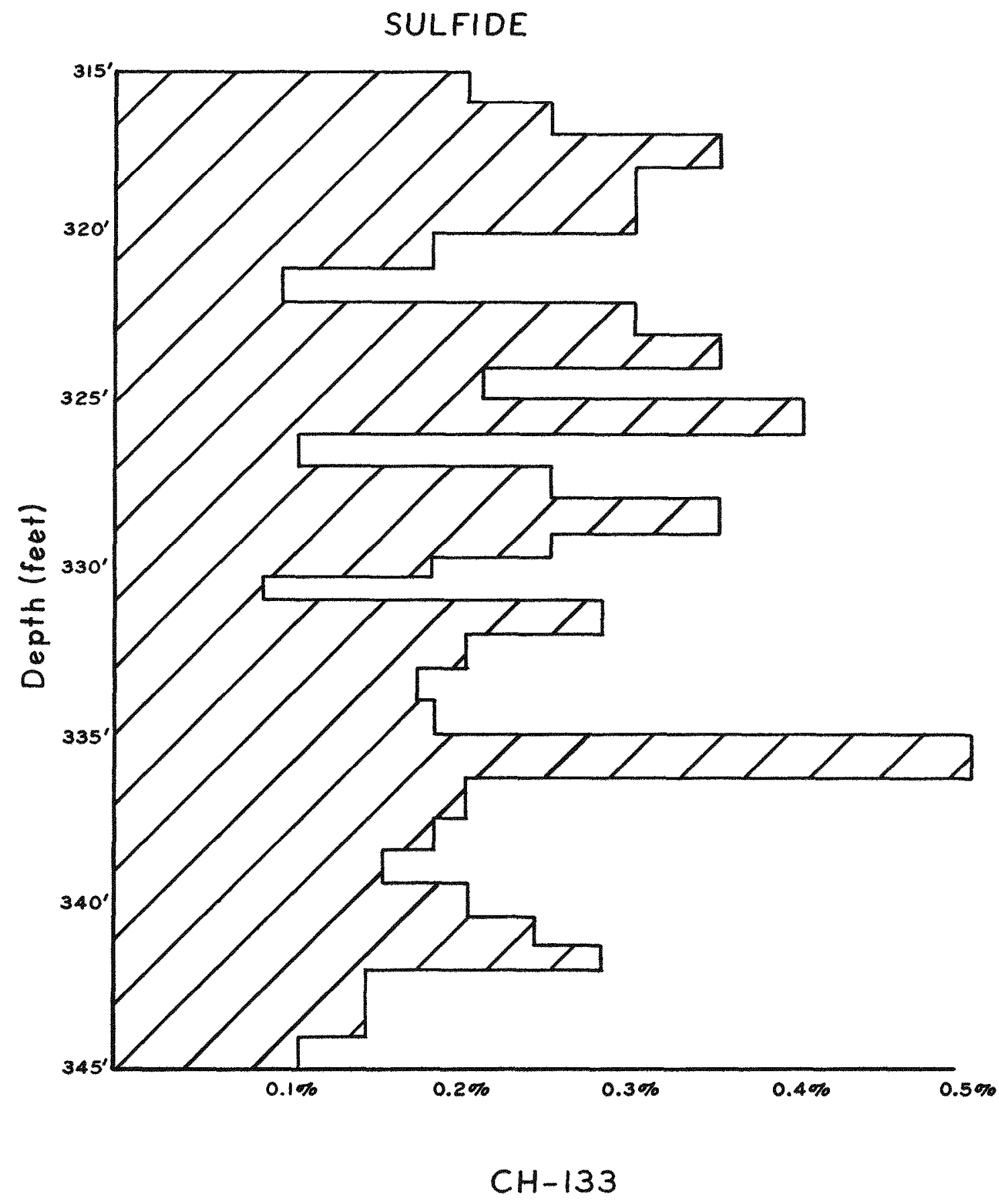




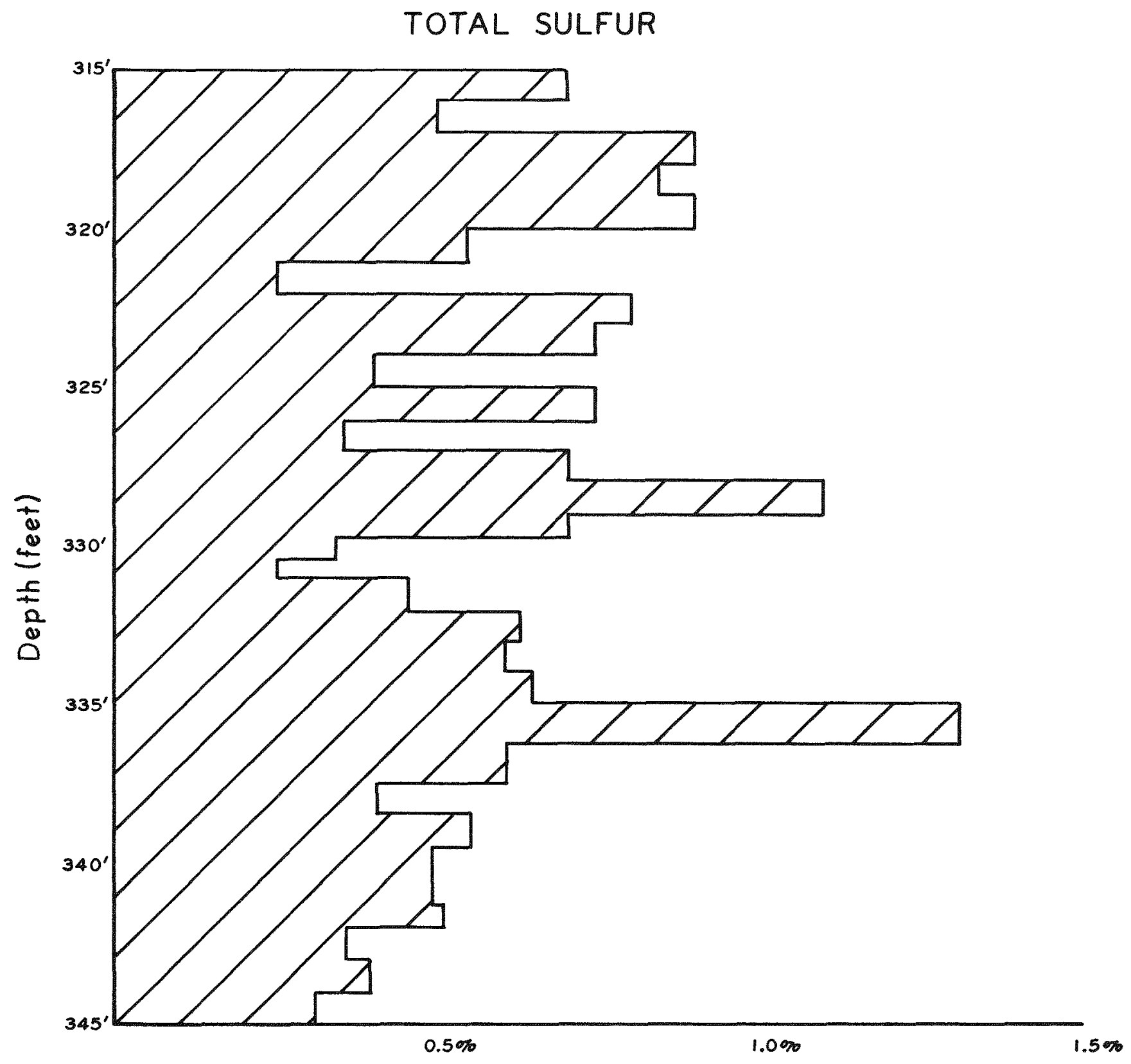

$\mathrm{CH}-133$ 


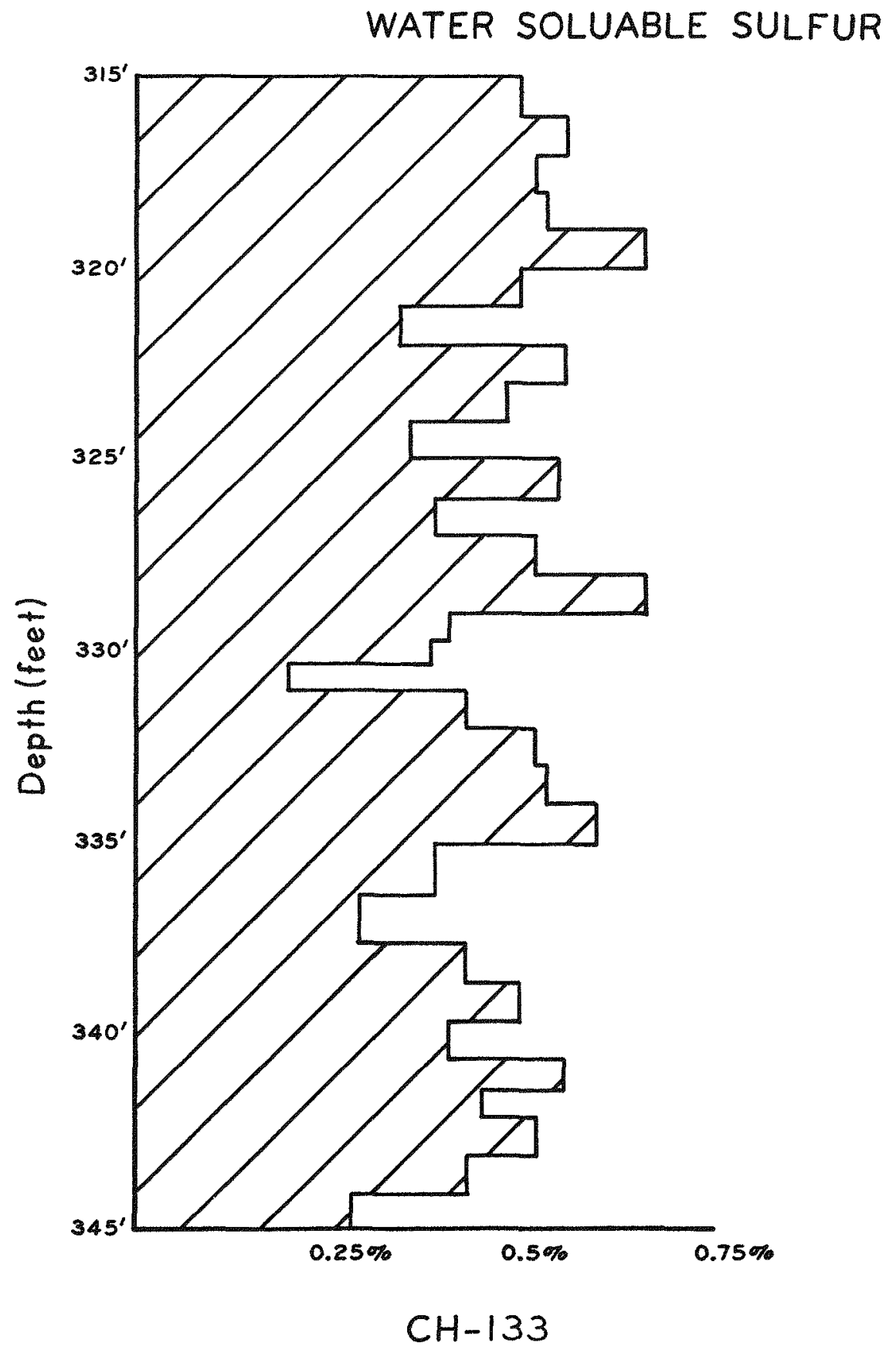




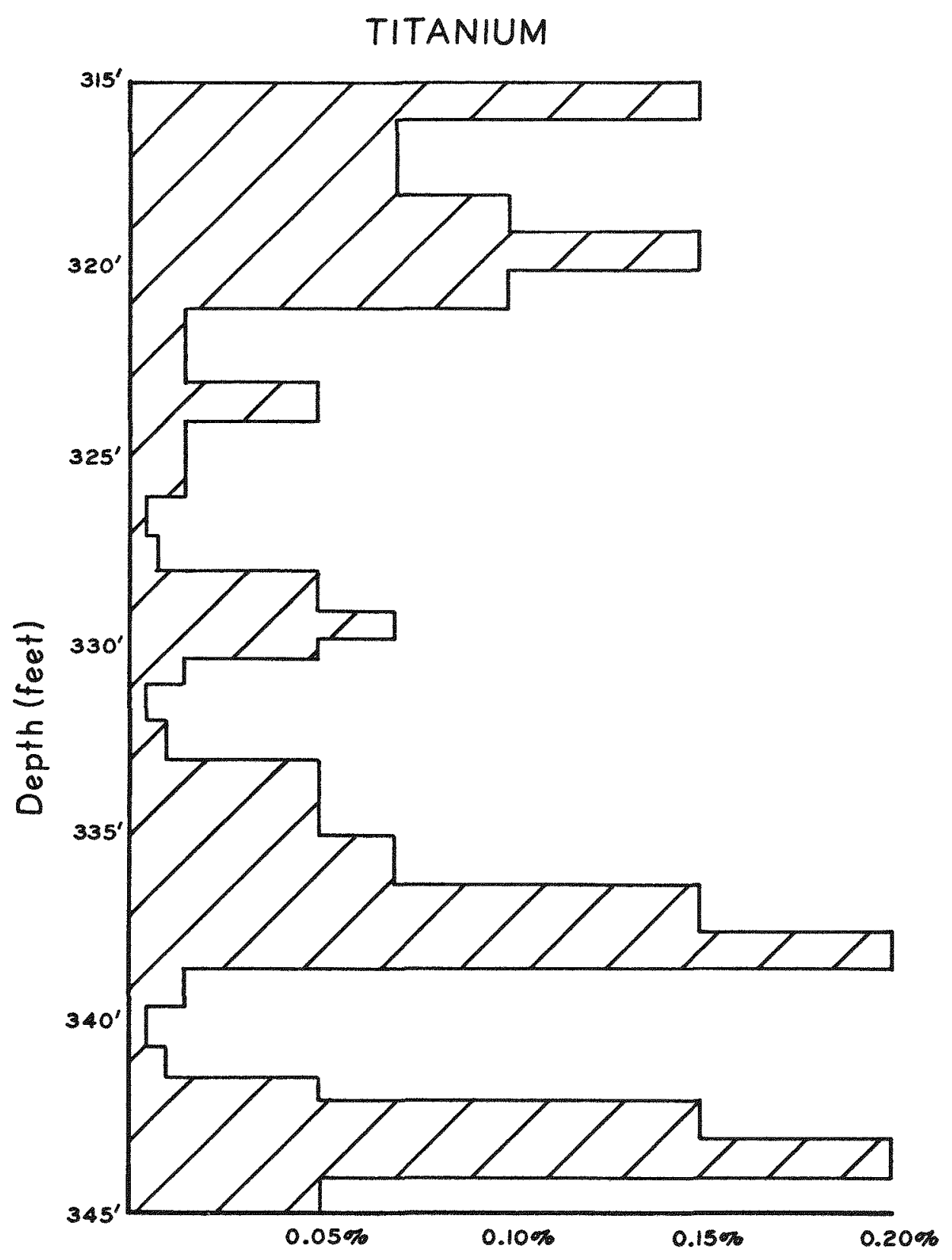

$\mathrm{CH}-133$ 


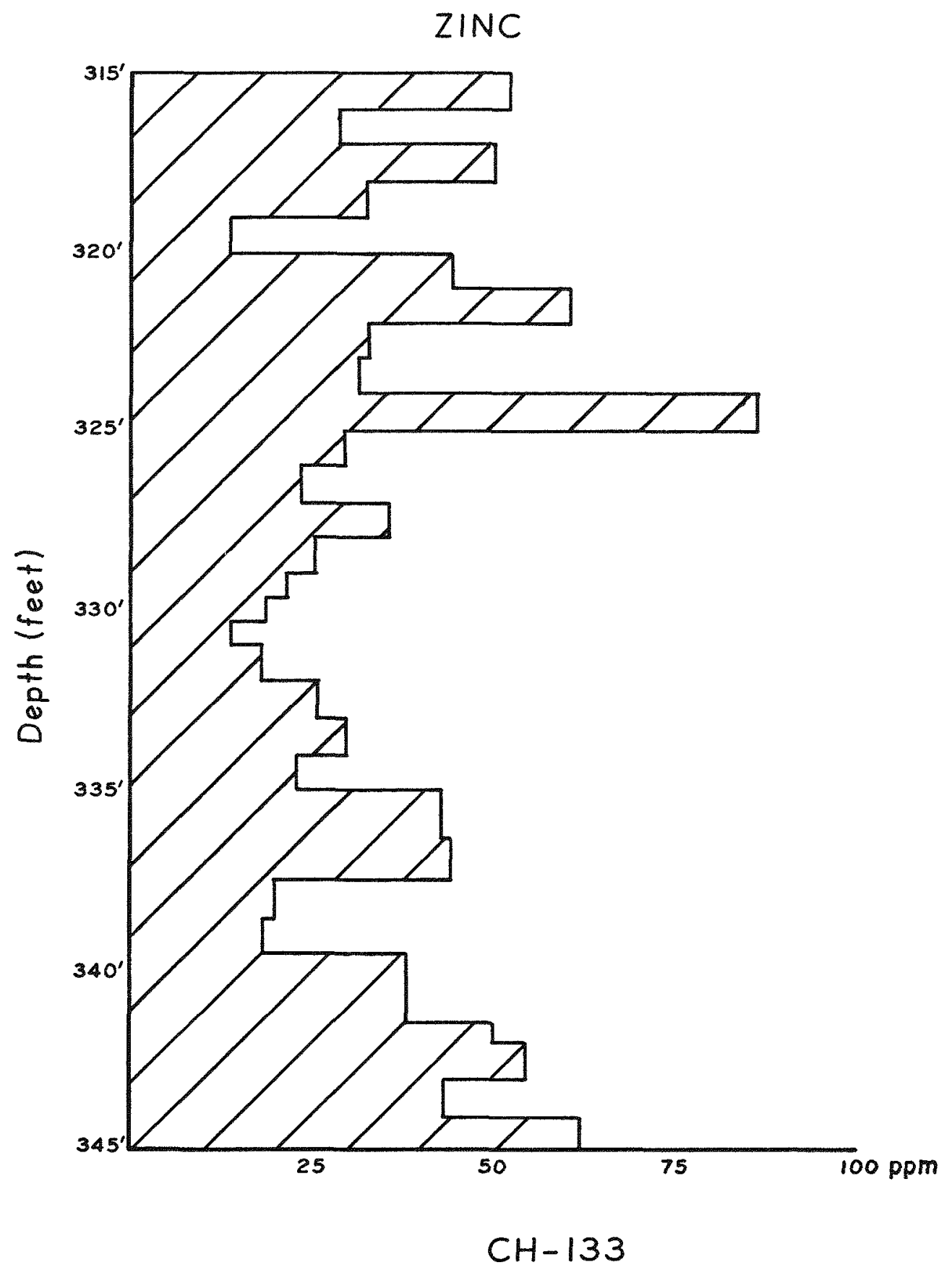




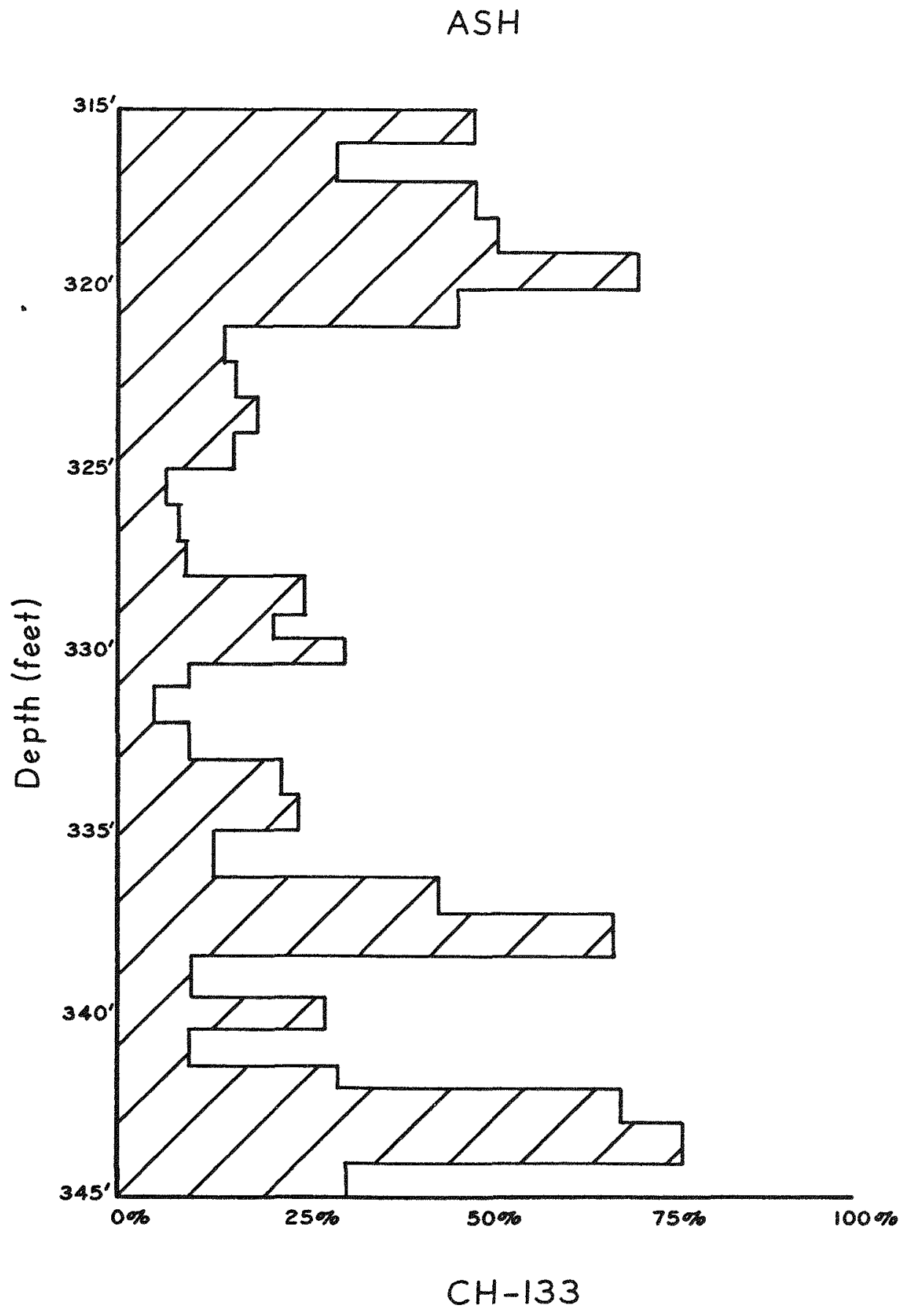




\section{APPENDIX C}

Structural Contour Map on Top of the Hanna No. 1

Coal Bed Using 1983 Seismic Data

(After Berkman and Orange) 


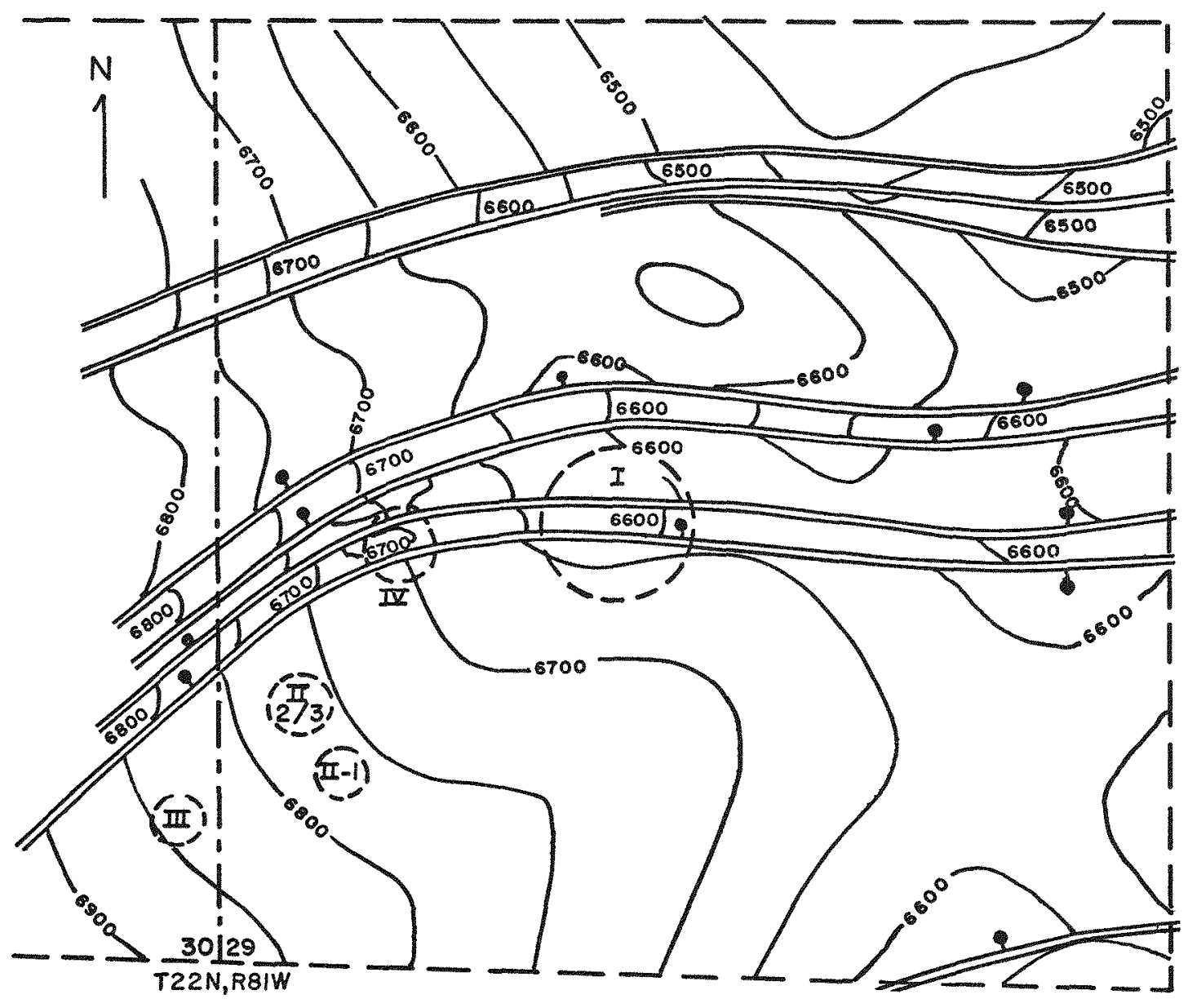

CONTOUR INTERVAL $=50 \mathrm{FT}$. SCALE

FAULT-

ELEVATION
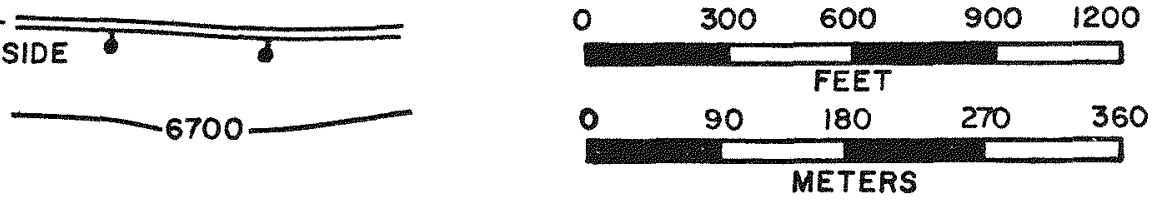